
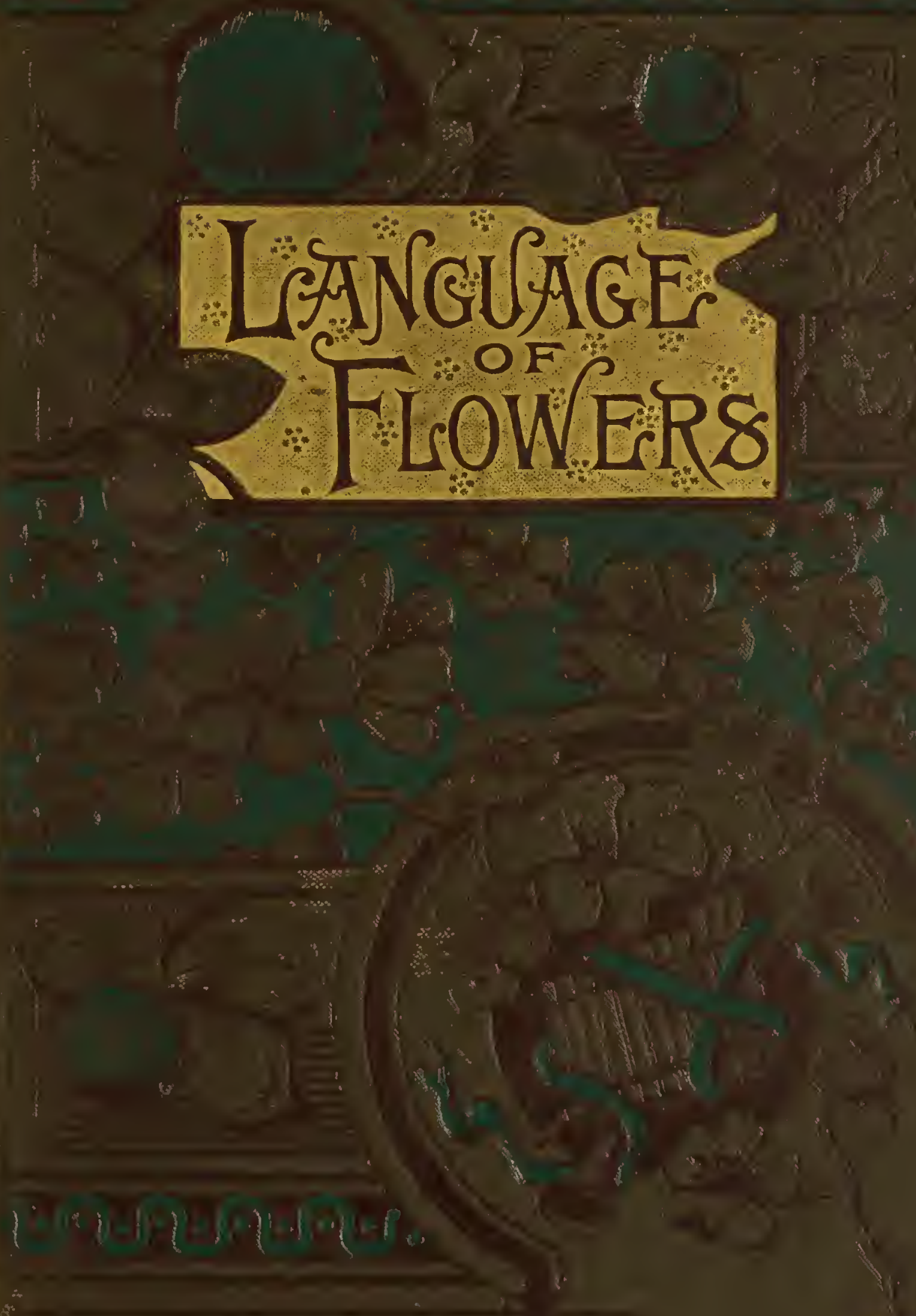

3 
32

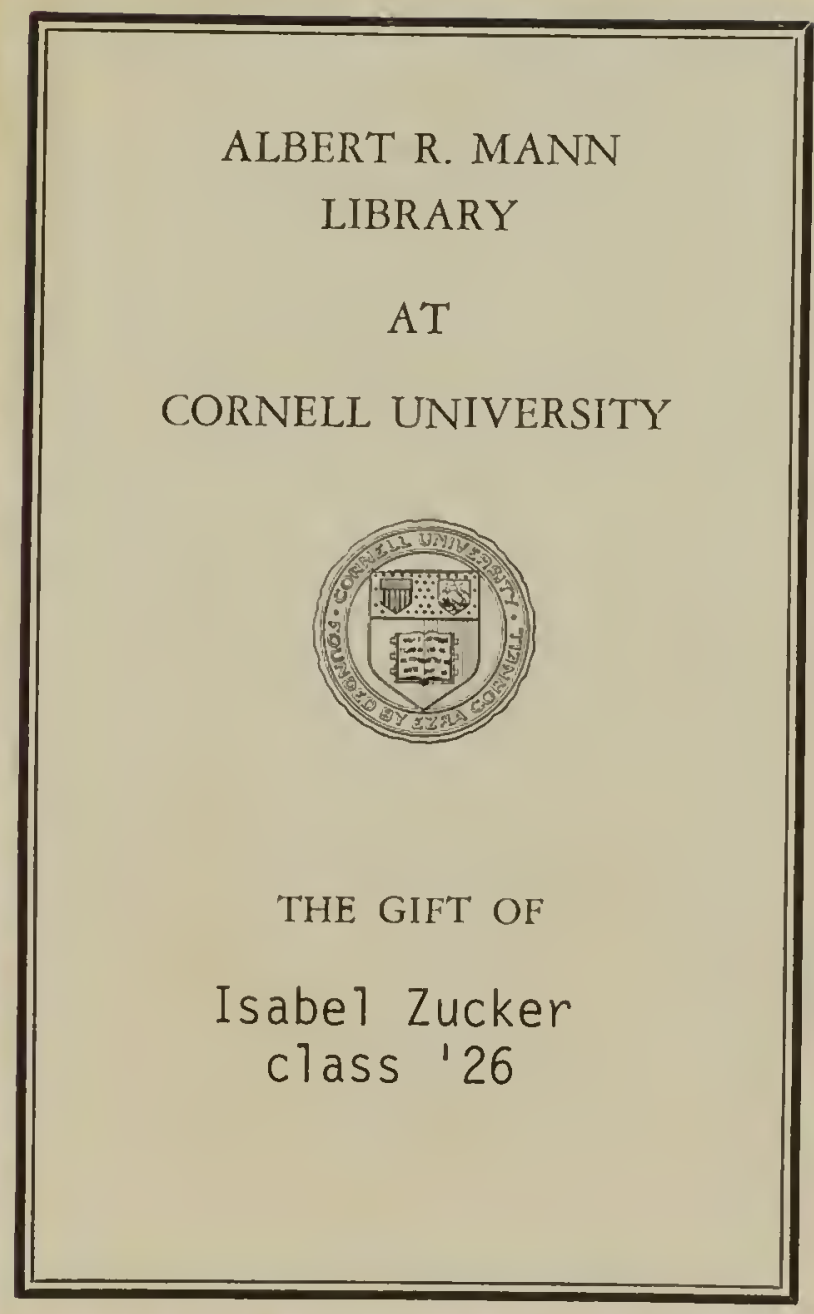



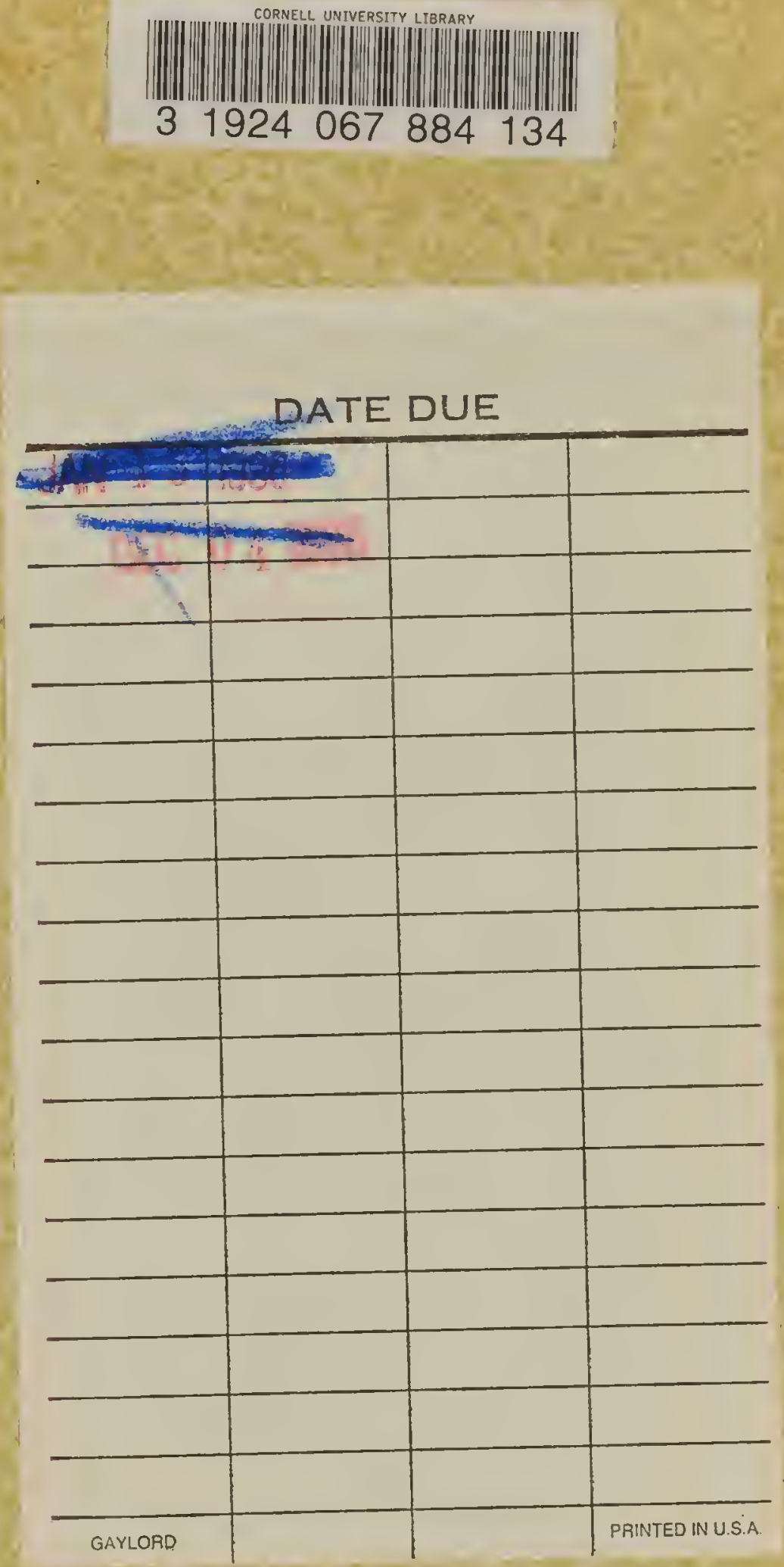



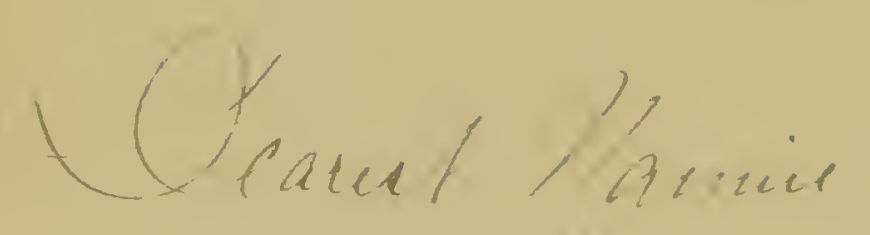
lith (Ue. 25,188\% 



\section{LANGUAGE}

AND

\section{POETRY OF FLOWERS}

SELECTED BY

MIR. C. MI KIRTLAND.

ILLUSTRATED.

CIICAGO AND NEW YORK:

BELFORD, CI, IRE \& CO. 1884. 


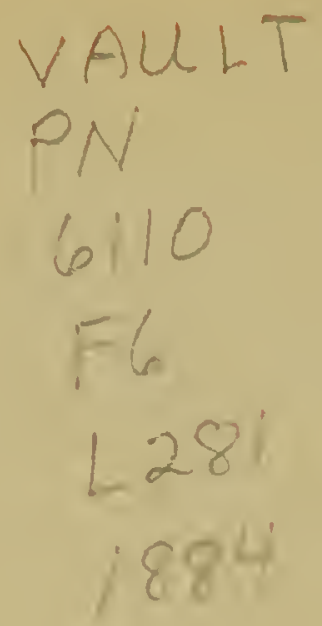

PRINTED AYI BOUND BSY

DONOHUE \& II HNNEBRRY, CHICAGO. 


\section{CON'TEN'TS.}

\section{FLORAL POESY.}

INTRODUCTORY ESSAY ON Flowers................ 7

The Darsy................................... 15

The Daisie...............Chancer............ 16

To the Daisy ........... Wordsworth ......... 16

To a Mountain Daisy........ Burns ........... 17

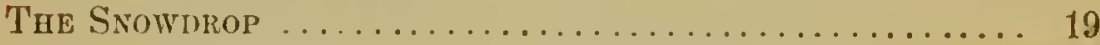

The Snowdrop............ Westwood............ 19

" " $"$.

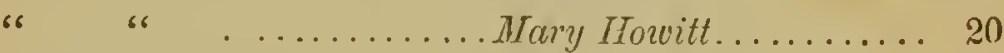

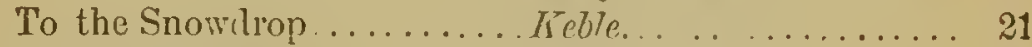

The Snowdrop............Mrs. Robinson........ 24

" " ...........Anon............. 2t

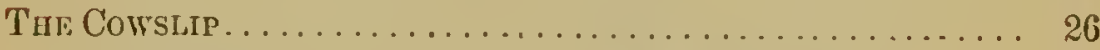

The Cowslip............ Mrs. Signmpry...... 27

Cowships.............. Mary Hoviit........ 27

The Cowslip. ............. L. E. Landon......... 29

The Crocus.... . .......................... 29

To a Crocus ............ Barton ............ 30

To the Crocus............ Patterson........... 32

The Apple-Bloosso.... . . . . . . . ................. 33

Apple-Blossoms................ E. Landon......... 33

To Plossoms............. IIerrick. ........... 3.

Thв Daffonil. . . . . . . . . . . . . . . . . . . . . .

Persephone............. dean Ingelow........ 35 
Daffodils . . Herrick $\ldots$ PAGE

The Violet. ............................. 38

To a Fading Violet ........ Shelley ............ 40

Violets................ Moultrie ........... 41

The Alpine Violet ........Byron ........... 41

The Angry Violets ........ Drayton ........... 42

Violets................L. E. Landon......... 42

A Bouquet of Spring Violets. Shelley . . ......... 43

A Violet Bank............ Shakspeare .......... 43

The Violet............... Goethe .... ........... 43

The Yellow Violet..........Bryant............... 44

The Narcissus............................. 46

Echo and Narcissus ....... Milton............. 47

Narcissus............................... 48

To a Mirror .......... From Garczlasso de la Vega 48

Death of Narcissus ....... Addison ........... 48

Narcissus.......... . . Cowper ... . . . . . . . 49 49'

To the Narcissus......... . . Ben Jonson . . . . . . . . 49

The Narcissus........... Keats ............ 51

" " $"$ "..........Gay . ........... 51

" " ............. E Landon......... 52

Buttercups ............... ............ 52

Buttercups.............Eliza Cook........... 52

The Hawtuor.......................... 54

Going a Maying ..........John Ingram......... 56

" $" \quad \ldots . . . \ldots$. Eliza Cook............ 57

The Primrose................................ 59

The Primrose.............Mrs. Hemaris. ........ 62

The Early Primrose........II. K. Whıte........ 63

Primroses.............. Keals . ........... 63

Sad Primroses........... John Wilson.......... 64

To a Primrose.......... Carringtin ........ 64

The Primrose ........... Irs. Bunter......... 65

To Primroses. . . . . . . . . . . Herrick . . . . . . . . . . 66

A Bouquet..............M. E. lsee......... 67

The Hyacinth........................... 67

The Hyacinth............Casimir ........... 68

Hyacintbus.............Keals............ 69 
The Rosemary

T'o the Herb Rosemary........

THE LILY OF THE VALLF ................

The Child and the lilly.

73

'The Lily of the Valley...... Croly............. 73

The Lily............... Percival ............ 74

" " $\ldots \ldots \ldots \ldots \ldots \ldots$. Colevidge .......... 75

I send the Lilies given to me..Byron............ is

Tue Pimpernel............................. $\tau_{6}$

Pimpernel ............. O. W. Holmes......... 77

TH: HearT's-EASE......................... 78

Heart's-ease. . . . . . . . . . . Mary Howitt. . . . . . . . 79

Origin of the Pansy's Name..Shakspeare........... 79

Pausies................Robt. Buchanan....... 80

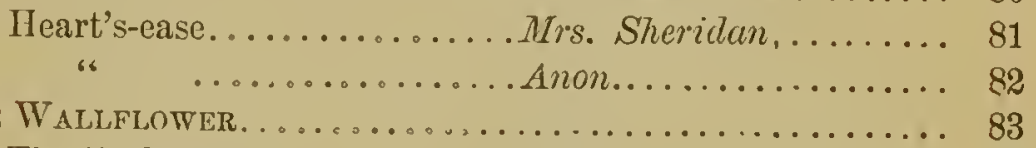

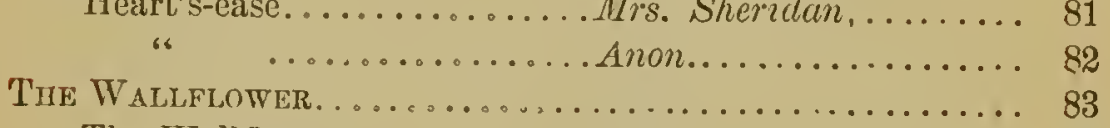

The Wallflower..........Morr. ................ 84

" " ..........Anon............ 86

The Naming of the Wallfower. Herrick............ 86

The Forgit-Me-Not............................ 87

The Bride of the Damube.....Pickersgill ........... 87

Forget-me-not............Anon.............. 89

" ............Moir............. 89

Song of the Forget-me-not................... 91

Forget-me-not. ... . ........ New Monthly Mrag...... 91

Can you forget Me............ E. Landon......... 92

Forget-me-not.............John Ingietu ....... 92

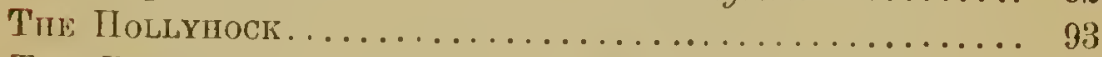

The Rose............................. 94

The Dying Rosebud. ........Mrs. Osgood........... 97

The Lesson of a Rose. .... . Spenser............. 9?

Zuleika's Rose.............Byron............. 99

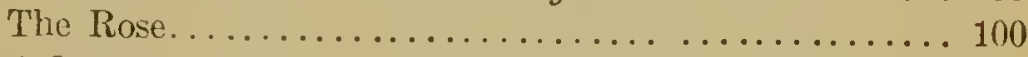

$\Lambda$ Song of the Rose.........Temans............ 100

The Rose.............. Etton.............. 102

The Iast Rose of Summer....tYoore.............. 103

Gather your Roses.......................... 104 
Ode from Anacreon.........Moore............. 104

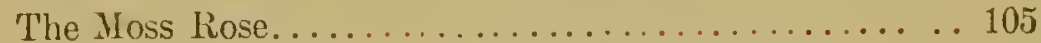

The Rose................. Camoens.............. 106

The Legaey of the Roses......L. E. Landon.......... 106

Gather ye Rosebuds.........Ilerrick............ 107

The Sensitive Plant........................ 109

The Mimosa..............Darwin ............ 109

Tue Erenting Primrose...................... 110

The Evening Primiose......Langhorne.......... 110

TuF Helotrope. . . . . . . . . . . . . . . . . . . 113

The Heliotrope...........Anon............. 113

Heliotrope .............Anon............. 114

The Sweetrrlar......................... 114

To the Sweetbriar..........Brainard........... 115

THE LADY FERN........................... 116

Lady Fern............... Calder Campbell........ 116

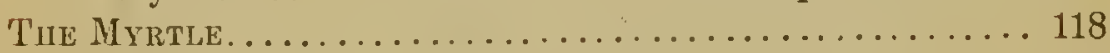

A Myrtle............... Keats .............. 118

Their Groves of Sicet Myrtle.Burns. . . . . . . . . 119

The Jasmine, . . . . . . . . . . . . . . . . . . . . 119

The Jasmine. ... . . . . . . . . Couper. . . . . . . . . . . 120

To a Jasmine Tree. . . . . . . . Lord Horpeth. . . . . . . . 120

Jasmine... . . . . . . . . . . . Hoore...... . . . . . . 121

Night-Seenting Jasmine . . . Noore. . . . . . . . . . . . 121

Perfume of Jasmine. . . . . . . Churchill. . . . . . . . . 122

On the Indian-J asmine I:Lower. Rycen. . . . . . . . . . 122

The Jasmine. . . . . . . . . . . Moore . . . . . . . . . . . . 123

To the Jasmine...........Jane Taylor.......... 123

THE PoppY............................... 124

Through the Fields........Savyer............ 125

The Oravge-Blossoms...................... 126

The Orimge-Tree...........Spenser............. 126

To the IIumming Bird. . . . . Charlotle Smith........ 127

The Oringe-Bough......... Itemans............. 128

THE ANEMONE. . ............... ....... 129

To the Anemone...........Pratl ............. 129

The Rer Anemone. ....... Tennyson .......... . 130

TgE ASPHODEL........................... 131 
THE

The Iloneysuekle.......... Countess of Blessington.. 132

Fragment............... Sir W. Scott......... 133

Woodbine...............Shakspeare.......... 133

The Question............ Shelley ............. 134

From the Rape of Proserpine. Barry Cornuall....... 135

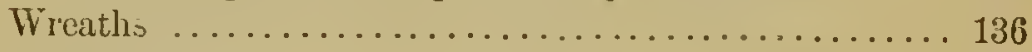

Ioneysuckles ...........Keats............. 137

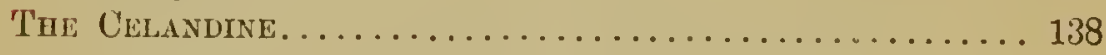

To the Small Celandine.....Wordswortic ......... 138

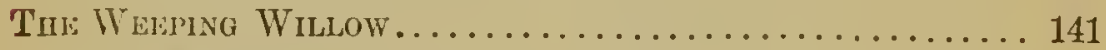

The Willow.............Byron............ 141

Wering the Willow....................... 142

The Willow.............Shakspeare........... 143

To a Willow Tree...........Herrick............. 144

The Garland..............Moore............... 144

Sonnet.................Garcilasso........... 145

The Drooping Willow.......L. E. Landon... ...... 145

Tue Sunflower ............................. 146

The Sunflower........... Thomson .......... 147

To the Sunflower....................... 147

The Sunflower................ E. Landon......... 148

" " " ..........IIood.............. 149

" " "...$\ldots \ldots \ldots$. Shelley.............. 149

Constaney...............Hoore............ 150

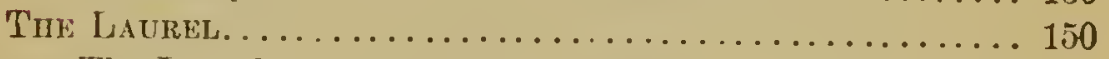

The Laurel.............. Tasso ............. 152

The Bay................. Cook............. 153

The Laurel ............. Wordsworth ......... 154

The Periwinkle............................. 155

IVild Flowers............Anon ................ 156

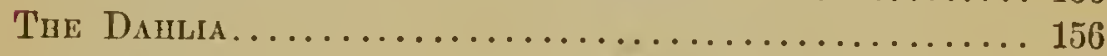

The Dahlia.............Mrtin............. 157

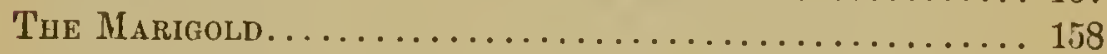

The Marigold............. G. Withers......... 159

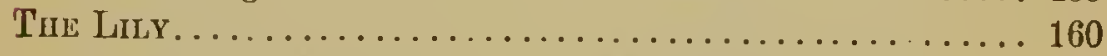

A Bouquet of Lilies......... Wordswort $\ldots . . . \ldots \ldots 161$

Water-Iilies ...........E. R. B.......... 161

The Closing Lily.......... Tennyson.......... 162 
$\Lambda$ Dialogue from Soul Giundert-

$$
\text { ing............. Hora Greenwedl. ...... } 16
$$

Une l'enséc.............Ilood... . . . . . . . . 16i3

The Wuter-lily........... Reynolds ........... 1ed

The Star and the IVuter-Iily O. W. Holmes ........ . 16i4

The Water-lily........... licynolds........ . . . 16i6

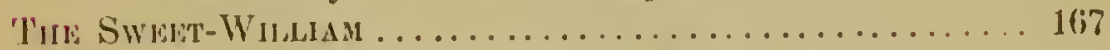

Swect-Willinm ...........Cowley ... ......... 167

The Gillytlower .......... Drayton............ 168

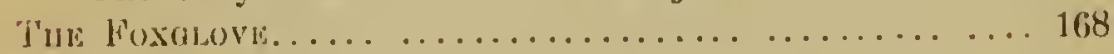

like foxglove......................... 169)

jul Fuchsia . . . . . . . . . . . . . . . . . . 169)

The Fuchsia............Anon............ 170

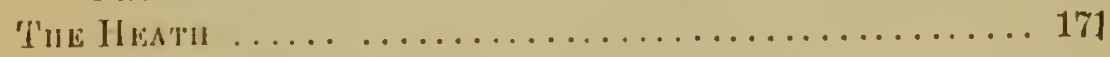

Moorlund Blossoms .. . . . . . F. Covt. . . . . . . . . 171

(1) a Sirigr of Heatl. .... . Mrs. Grant. . . . . . . . 173

Houth......................... 174

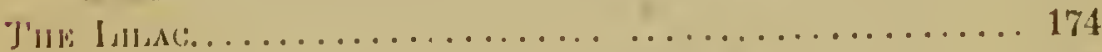

J'he lilne ............. . Thomson ........... 175

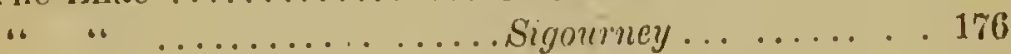

. “ ............Bums........... 176

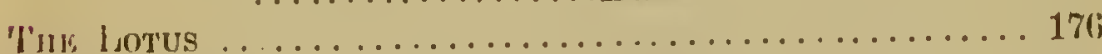

'The Lotus.............. Tennyson ........... 176

Switet Pkas. .............................. 178

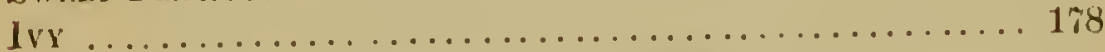

The Ivy Green.............Dietiens. . . . . . . . . 178

Ivy. . . . . . . . . . . . . . . Calder Camplell . . . . 180

Ground Ivy ........................... 180

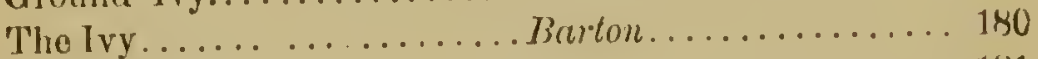

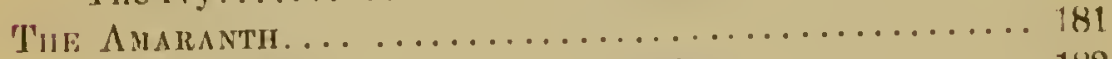

'The $\Lambda$ marinth . . . . . . . . . Shelley. . . . . . . . . 182

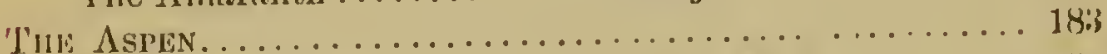

The $\Lambda$ spen 'Trec........... Charles Swain ........ 184

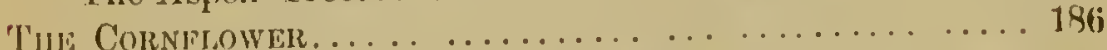

Ficld Flowers........... Campbell........... 18 \%

Tur Cypress . . ............... ... ......... 188

The Cypress Wrenth ........ sir W Scott ......... 18!

The Cypress 'Tree............Blackrevod's May ..... 190

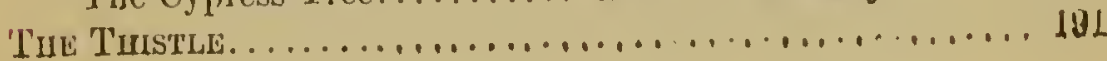




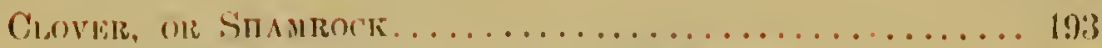

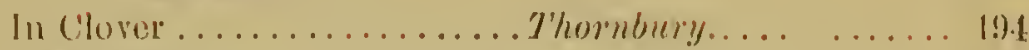

Des1, Lanvis. . . . . . . . . . . . . . . . . . . . . . . . 195

Deadl beares . . . . . . . . E Ella Ingram. . . . . . 195

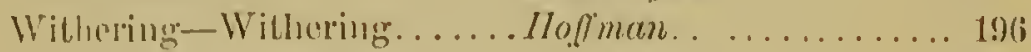

'Ти:

The Mistetoe ......................... 198

Under the Nistletoo . . . . . . . . . . . . . . . . . 198

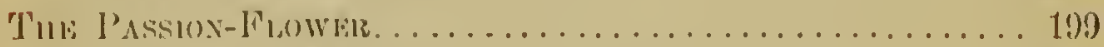

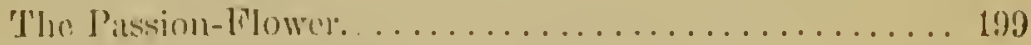

To tho Pission-Flower. . . . . . Parton . . . . . . . . . . . 200

'The P'tssion-H luwer. . . . . . A Anon. . . . . . . . . . . . 201

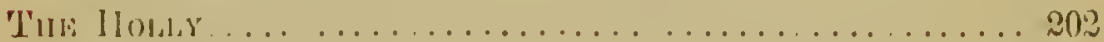

'Tle Ilolly-Tree . . . . . . . . . . . .

The Ilolly. . . . . . . . . . . k. Cook . . . . . . . . 20.1

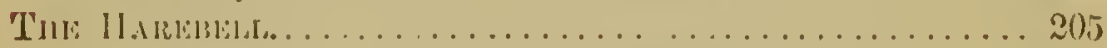

The Hatrobell. . . . . . . . Ileber . . . . . . . 20.5

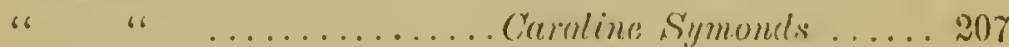

“ $\quad$ “ ........... Sir W. Scolt. . . . . . . 209

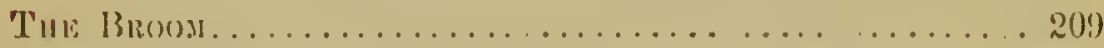

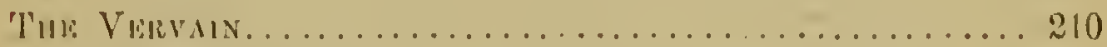

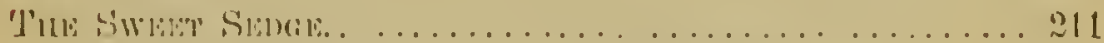

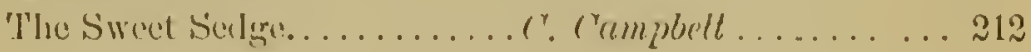

\section{LANGUAGR ANI) VOCABUIARY OH JlAOWLIR.}

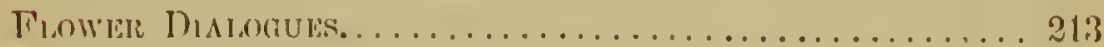

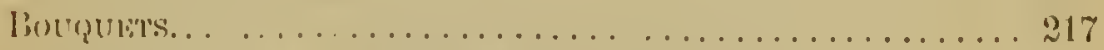

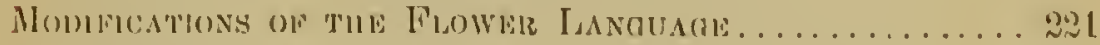

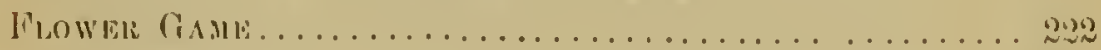

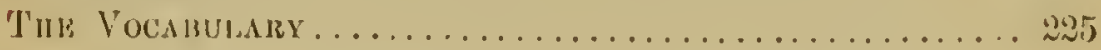

\section{'THE POE'TRY OF FLOWERS.}

The Poetry of Flowlirs....................... 26.5

Funcy ...............keats............ $26 i 7$

Novembre. . . . . . . . . . . Bryant. . . . . . . . . . $2 \pi$

The Death of the Flowers..... C. Bowles ........... 271 
Farewell to the Flowers..... Sigoniney......... . . 272

To the Fringed Gentian. . . . . . . . . . . . . . . . 274

Fading Autumn. . . . . . . Kinney............275

The Night-flowering Cereus. . Anon............. 276

The Indian Summer . . . . . Dixon . . . . . . . . . . 277

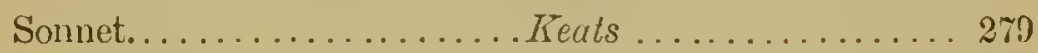

The Human Seasons ....... "

A Dead Rose................ B. Browning ...... . 281

The Last $\Lambda$ utumnal Walk.... W. P. Palmer.......... 283

Winter................Southey ............ 286

Lines to a Friend. ..........T. . . Palmer..... .... 287

Lines to an Orange-Tree.... 6. 6 "6 ....... 288

Winter Piece..............J. R. Lowell. . . . . . . . 291

The snow-Storm............R. W. Emerson. . . . . . 293

The Furst of December... . . . Southey . . . . . . . . . . . 294

On a Forget-me-not.........Kemble............. 297

The Itaurustinus. . . . . . . . . . Montgomery . . . . . . . . . 298

The South ...............R. II. Stoddard........ 299

A Grave at Greenwood.......I. A............... 302

Christmas Day .. ........ C. IIarvey............304

The Green-Hotise Rose....... . Smath............ 305

The Christinus-Tree........ Rev. C. T. Brooks ..... 307

The Sweet-scented Cyclamen. Mrs. Southey.......... 311

Rose Standish.... ........F. M. Caulkins......... 313

The Opening Year.......... Shelley............. 310

The Thrush. ............. Burns............. 317

The First of January. . . . . . . Southey . . . . . . . . . . 318

Transmigration...........Anon .............. 321

The Friendship Flower.......Milnes .............. 323

To a Rose on New-Year's Day. Anon............... 325

Frergreens..............Pincheney ........... 326

My Пleart 's my Greenhouse...W. L............. 327

To a Withered Rose.........Wm. Whitman... . . . . 329

To a Flower. . . . . . . . . . . . I. W. Parker. . . . . . . . 330

The New Year............ Tennyson............ 332.

Childhood..............Anon............. 383

A Day in June.............. R. Louell........... 334

There is a Tongue in Every

Leaf............... Anon ............ 
The Town and Ce untry Child A. Cunnengham........ 339

A IJouse and Grounds . ....Leigh Hunt. . ... .... 343

To the Butterfiy..... . . . . Rogers.... . . . . . . . 344

Jeune Fille et Jeune Fleur. . Chrteaubriand. . ..... 345

The Rosebud............ Keble.. . ........... 346

The Little Red Rose....... Goethe ....... . .... 349

The Drop of Dew..........Anon............. 350

Cupid and the Dial......... " . ........... 352

Go, Lovely Rose. .... . . ... Waller ............. 353

Sur la Mort d'une Jeune Fille. Malesherbes . . . . . . . . . 354

A Midsummer Legend ... . . . Hary Howitt. . . . . . . . 355

The Morning-Glory. . . . . . . . Mirrta Lowell. . . . . . . . . 359

Myself................Arey ............ 361

The Fountain ........... Anon.............. 366

Song of the Flower Angels....Mrs. Hale........... 368

Morning ..............Caroline A. Briggs..... 370

Odle to Evening. . . . . . . . . Collnns. . . . . . . . . . . 372

To the Grasshopper and the

Cricket.............Anon............. 375

The Nightshade......... " . ........... 376

The Star and the Water-lily..O. W. Holmes...... . . 377 To a Butterfly seen in a Crowd-

ed Street.............W. P. Palmer....... . . 379

Gold Fishes.............H. Eoleridge......... 382

Somnet................. Shukspeare .......... 384

Sabbath Evening............. D. Prentice........ 385

White Roses...............S. L. P. Smith ..... . . 387

The Lily.................J. G. Percival......... 388

Petition for an Absolute Re-

treat. .............Countess of Winchelsea . 390

Not to Myself Alone.........Anon. . . . . . . . . . . 394

Spring in the Lap of Winter. . " ............ 397

Arcadian Hymn to Flora . . . R. H. Stoddard. ...... 398

Flowers.................. H. W. Longfellow.... . 404

Fally Morning ............. E. Starr......... 407

Song in Praise of Spring. . . Barry Cormwall. .. . . 408

Come ! Let us go to the Land. " " . ..... 409

March................W. ( B Br, ant....... 410

A Spring Song . .........E. Youl .......... \&12 
The Voice of the Grass. ... . Anon..............445

Flowers ............. $6 \ldots \ldots \ldots \ldots 417$

Blue Flowers.............. . Eustis........... 420

The Garden. ........ . . . Indrew MLarvell... . . . . 422

Flowers................Barry Cornwall........ 425

The Vernal Shower .........4trs. Hemans. . . . . . . 420

The Sun...............Southey. ........... $4: 7$

The Daisy............... Wordsworth.......... 4:8

MIossgiel ............. "6 ........ 432

The May Morning . . . . . . . . Grace Greenwood. . . . . . 433

Evening Rainbow.......... Southey ........... 45J

Night................ William IIabıngton... . . 430

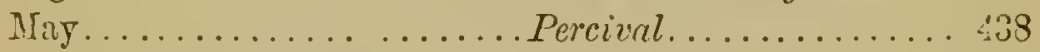

IIymn to the Flowers ........ Morace Smith . . . . . . . 439

Ilector in the Garden........ E. B. Brouning. ...... . 44?

Iymu ................Anon.............. 447

Late Spring ..............Southey............ 449

Fine Weather in May. . . . . . Leigh IIunt. . . . . . . . . 450

To a Flower..............Anon.............. 452

The Origin of Dimples..... " ............ 453

To Corinna, to go a Maying. . . Merrick.............. 455

The Close of Spring........... Smith............ 457

Summer ...............R. II. Stoddard... . . . 458

Junc...................Yary 2 V. Weigs . . . . . 459

The Tulip and Egrantine.....Anon.............. 472

On Observing a Blossom on

Februaly 1st ........S. T. Coleridge........ 463

Valentine..............Southey............ 404

The Birdie's Song.... . ...Anon............. 465

A City Lyric.... .........T. Westwood.......... 466

The Teachings of Eva........E. Oakes Smith..... . . 468

life.................. Charles Mackny........ 169

Solig ...............Tennyson........... 471

Song for August. . . . . . . . . . Marriet Martinenu . . . . 472

The Fire-Fly. ......... . . B. Barry Cornuall ....... 473

Autumn Flowers..... ... . . Carolne Southey....... 474

Songs and Chorus of the Flow-

ers ............Leigh IIunt.........445

A Still Day in Autumn.... ...Mrs. Whitman........ 479 
The Moon..............Hood............480

The Evening Gillyflower......Anon............ 482

The Reaper and the Flowers. Longfellow............ 484

The Falls of the Passaic. . . . W. Irving. . . . . . . . 486

The Wasted Flowers........W. Bowen .......... 488

The Chosen Tree........... "Estelle"........... 491

A Noeturnal Reverie........ Countess of Winchelsea. 493

The Use of Flowers..........Mary Howitt.......... 494

The Setting Sun...........Sir W. Scott........ 497

The Elm Sylph........... H. W. Parker........ 498

The Anemone ............. Hartley Coleridge .... . 499

Oetober................W. C. Bryant........ 501

Grief's Neglect........... Tennyson........... 502

The Sensitive Plant.......... . B. Shelley ........ 503

Ode on Melancholy......... Keats ............ 505

The Child and the Autumn

Leaf............... Saml. Lover........... 507

Birth-Day Flowers..........Anon............. 508

Song for the Season.........E. Cook........... 509

Lessons from the Gorse....... E. B. Browning....... 512

Work without Hope......... Coleridge . . . . . . . . . . 514

Emblems of Flowers.........Burns............. 515

The Rose................ Beaumont \& Fletcher... 516

The Captive and the Flowers. Goethe ........... 516

Fragment .............Sir W. Scott ........ 520

Sonnet................ Spenser.......... 520

Children of the Sun's First

Glaneing........... Schiller............. 521

Flowers for the Heart. .... Elliott............ 522

Flowers sent me during III-

ness................ II. Dana. . ...... 523

The Dandelion ...........J. R. Lowell......... 525

To the Snowdrop .......... Barry Cornuall....... 527

Field Flowers ........... Campbell ........... 529

The Rhodora............... W. Emerson. ..... 530

The Flower ............. George Herbert. ...... 531

April................... W. Longfellow...... 533

Buttereups and Daisies. . . . . Mary Ilowitt. . . . . . . . 535

May.................. Willis. ............. 587

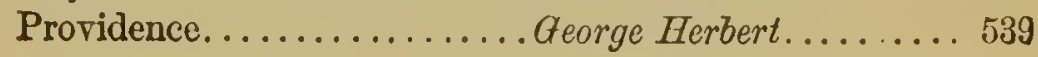





\section{INTRODUCTION BY AMERICAN EDITOR.}

No apology is needed for having brought together,
in a presentable form, a few of the many beautiful things that the poets have written on flowers. The impulse was a natural one, originating in love of the subjeet, and a desire that others should feel and enjoy the pleasure of familiarity with the best and highest thoughts upon them. The idea of sueh a eollcetion once entertained, the only diffieulty was what to omit. No one who has not examined English poetry with an especial view to the poetry of flowers, could imagine the extent to which that rich theme has inspired the Bons of song. Only I love has prompted more verses; and even that universal topie is so indebted to the 
illustration of flowers. that we cannot but perceive their clicim to be aimost equal in extent.

Whatever may seem capricious in this selection, is to be ascribed to redundance and excellence of material. The plan required that variety of topics and treatment should be a leading object, and this excluded some of the most charming flower-poetry. Then, again, some pieces of that kind had, from their very excellence, already found their way into every school readingbook, and it seemed superfluous to reprint them here. And more than all, the quantity of verses which the editor had supposed could be contained in a good-sized volume, proved so much beyond the capacity of any volume of tolerablc proportions, that a great mass of dearly beloved poems were absolintely crowded ont. There will, however, be found in this little volume something for all tastes, as well as for all seasons. It contains a brief sketch of the mythology and symbolism of flowers; some hints with regard to their practical utility; selections from the poctry inspired by them; and a full explanation of their language, in the shape of a Vocabulary and Flower Dialogues. A 
game for home is alsc suggested, to be played with these lovely gifts of nature. 'Thus, it is hoped, that alike in sunshine and shade-when June's red roses delight us, or "rain and wind beat dark December"our readers may enjoy a perenuial Bouquet. 


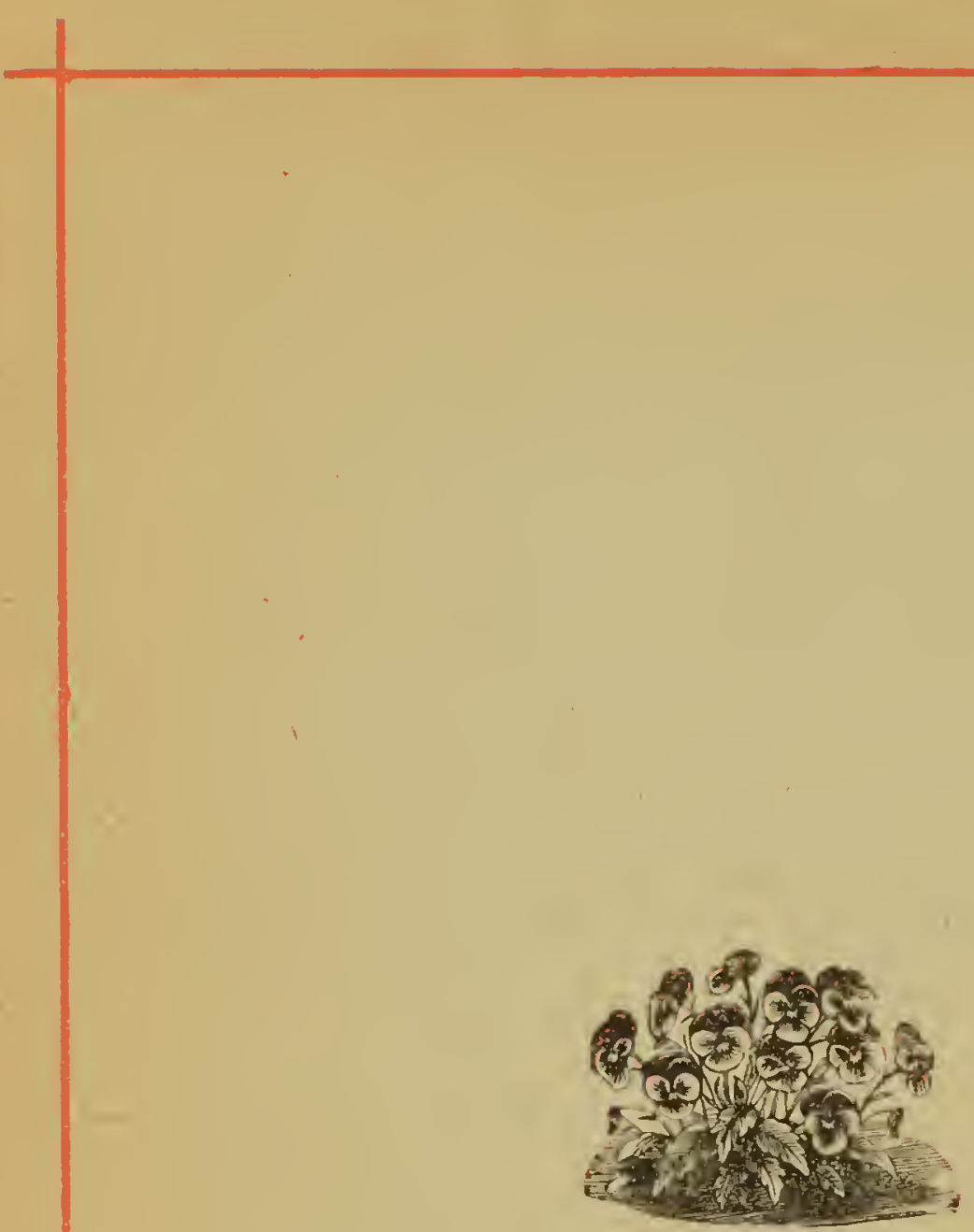




\section{FLORAL POESY.}

\section{INTRODUCTION.}

THE most charming of all gifts is one of flowers.

1 A queen may give them to lrer subjects; and the poorest subjeet maly offer them to a monareh.

They are the representatives of all times and of all nations; the pledges of all feelings. The infant plays with them, and gains his first idea of beauty from their blossoms; the lover gives them to his beloved; the bride wears them. We offer them to our beloved dead; dynasties are represented by a flower; nations adopt them as their emblems. Universal is their hold on human sympathies; universal their language.

Floral Poesy is, therefore, the most appropriate of all presents; and, in giving this title to a language of flowers, and a eolleetion of eharming poems on them, we believe we have not been guilty of a misnomer.

Hood, in the following pretty lines, has afforded us an admirable introduetion to our poetieal Posie :-

"Welcome, dear Heart, and a most kind good-1norrow ; The day is gloomy, but our looks shall shine :Flowers I have none to give thee, but I borrow Their sweetuess in a verse to speak for thine. 
"Here are red Roses, gathered at thy chəeks, The white were all too happy to look white: For love the Rose, for faith the Lily speaks ; It withers in false hands, but here 'tis bright I

"Dost love sweet Hyacinth ? Its seented leaf Curls manifold,--all love's delights blow double: "Tis said this floweret is inseribed with gricf,-But let that hint of a forgotten trouble.

"I plueked the Primirose at night's dewy noon; Like Hope, it showed its blossoms in the night;'Twas, like Endymion, watehing for the 11 oon! And here are Sunflowers, amorous of light !

"These golden Buttereups are $\Lambda$ pril's seal,The Daisy stars her constellations be : 'These grew so lowly, I was foreed to kneel, Therefore I pluck no Daisies but for thee !

" Ilere's Daisies for the morn, Primrose for gloom, Pansies and Roses for the noontide hours :A wiglit onee made a dial of their bloom,So may thy life be measured out by flowers!"

Our readers will perceive that the symbolism and language of flowers were not unknown to the poct. Mrs. Browning says truly and charmingly :-

"Love's language may be talked with these ;

To work out choicest sentences,

No blossoms can be meeter ; And, such being used in Eastern bowcrs, Young maids may wonder if the flowers Or meanings be the sweeter.

"And such being strewn before a bricle, Her little foot inay turn aside,

'Their longer bloom decreeing, Unless some voice's whispered sound Should make her gaze upon the ground Too carnestly for seeing. 
"And such being seattered on a grave, Whoever mourneth there, may have

A type which seemeth worthy

Of that fair body hid below,

Which bloomed on earth a time ago,

Then perished as the earthy.

"And sueh being wreathed for worldly feast, Aeross the brimming cup some guest

Their rainbow colors ricwing, May feel them, with a silent start, The eovenant his childish heart

With Nature made,-renewing."

\section{And Leigh Hunt playfully declares:-}

s. An exquisite invention this,

Worthy of love's most honeyed kiss,

This art of writing billet doux

In buds and odors, and bright hues ;

In saying all one feels and thinks

In elever daffodils and pinks,

Uttering (as well as silence may)

The sweetest words the sweetest way .

How fit, too, for the lady's bosom,

The plaee where billet doux repose 'um.

"How charming in some rural spot, Combining love with garden plot, At once to cultivate one's flowers, And one's epistolary powers, Growing one's own ehoice words and faneies In orange-tubs and beds of pansies;

One's sighs and passionate declarations

In. odorous rliet'rie of earnations ;

Seeing how far one's stoeks will rench ;

Taking due care one's flower's of : peech

To guard from blight as well as bithos, And watering every day one's pathos. 
"A letter comes just gathered - cie Dote on its tender brillianey; Inhale its delieate expression. Of balm and pea ; and its eonfession Made with as sweet a maiden blush As ever morn bedewed in bush ; And then, when we hare kissed its wit, And heart, in water putting it, To keep its remarks fresh, go round Our little eloquent plot of ground, And with delighted hands eompose Our answer, all of lily and rose, Of tuberose and of violet, And little dirrling (mignonetle), And gratitude and polyanthus, And flowers that say, "Folt never man thus !"

How the flowers may be made to hold a conversation, Christine Pire tells us in the following dialogue :-

THE LOVER.

"I give to thee the Autumn rose, Let it say how dear thou art; All my lips dare not disclose.

Let it whisper to thy heart ; How love draws my soul to thee, Without language thou may"st soe.

\section{THE LADY.}

"I gire to thee the aspen-leaf"Tis to show I tremble still When I muse on all the grief Love ean cause, if false or ill ; How, too, many have believed, Trusted long, and been rinceivert. 


\section{LOVER.}

"I give to thee a faded wreath, Teaching thee, alas ! too well, How I spent my latest breath, Seeking all my truth to tell ; But thy eoldness made me die Vietim of thy eruelty.

\section{LADY.}

"I give to thee the honey-flower, Courteous, best, and bravest knight:

Fragrant in the summer shower, Shrinking from the sunny light:

May it not an emblem prove Of untold, but tender love?"

Flowers also are used for divination. All readers of Goethe will remember Marguerite's flower. Our own poet Lowell sends the following pretty lines on the subject, with a pressed flower :--

"This little flower from afar,

Hath come from other lands to thine ;

For once its white and drooping star

Could see its shadow in the Rhine.

"Perehanee some fair-haired German maid Iath plucked one from the self-same stalk, And numbered over, half afraid, Its petals in her evening walk.

“ 'He loves me loves me not !' she cries ;

'He loves me more than earth or heaven !' And then glad. tears have filled her eyes To find the number was uneven.

"And thou must count its petals well, Because it is a gift from me :

And the last one of all shall tell Something I've often told to thee. 
"But here at home, where we were born Thou wilt find flowers just as true, Down-bending every Summer morn With freshness of New England dew.

"For Nature, ever kind to love, Hath granted them the same sweel tongue, Whether with German skies above, Or here our granite roeks among."

There is another mode, resembling the Scottish and English superstitions on Hallowe'en and St. Agnes' Eve, by which maidens in Germany seek to dive into futurity. It is by the St. John's Wort. The story is prettily told in these lines, which we transcribe from the "Flora Symbolica :" -

"The young maid stole through the eottage door, And blushed as she sought the plant of power;

- Thou silver glowworm, O lend me thy light, I must gather the mystie St. John's-wort to-night ;

The wonderful herb, whose leaf will decide If the eoming year shall make me a bricle!'

And the glowworm eame

With its silvery flame,

And sparkled and shone

Thro' the night of St. John ;

And soon as the young maid her love-knot tied,

"With noiseless tread

To her chamber she sped,

Where the speetral moon her white beams shed.

'Bloom here, bloom here, thou plant of power.

To deek the young bride in her bridal hour?'

But it drooped its head, that plant of power,

And died the mute death of the voiceless flower;

And a withered wreath on the ground it lay,

More meet for a burial than bridal day. 
And when a year was past away,

All pale on her bier the young maid lay !

And the glowworm eame

With its silvery flame,

And sparkled and shone

Thro' the night of St. John ;

And they elosed the cold grave o'er the maid's cold elay."

Games also are made of flowers. In faet, time would fail to tell of all the joy and beanty which.these sweet ereations bestow upon humanity. Through life to death they eheer us; and it is not one of the least of our antieipated joys hereafter that we shall dwell amid those flowers of Paradise, of which these earthly blossoms are but faint shadows.

And in these days of utility, when a thing is nothing if not useful, we must remind our readers that the vegetable and floral world holds in it the seeret of health to a greater degree, we believe, than is yet dreamt of in our philosophy. They make the air we breathe pure and life-giving. It is a known faet that Lavender and many other flowers supply ozone to the atinosphere; the humble Liehen was one of the ingredients in the dye of imperial purple, for which Tyre and Sidon were famous; and the seareh for it brought Phœnieian eommeree to the Irish shores in the days of Ptolemy. Another Liehen, the Rocella tinetoria, afforded the first dye for British broad eloths. The Mosses shared in this utility.

The Dandelion affords the Taraxaeum, a valuable medieine. The tubers ealled "Lords and ladies," dear to babyhood, furnish a speeies of Arrowroot. The tubers of the Orehis afford a similar preparation ealler salep, a favorite posset with our great-grandmother's.

The Rock Samphire bestows a prekle on our tables.. 
The Red rose leaf is an admirable tonic; the Lily leaf heals a cut. Chamomile is a tonic. Cowslip affords a wine and a puddıng, besides an ınfant's ball ; the Lesser. Celandine is still used $\mathrm{m}$ medicme for the relief of a painful disease; and who is ignorant of the blessed soothing powers of the Poppy and Henbane? Greek mythology has left a floral record ; the Mistletoc, Vervain, and St. Joln`s Wort recall Druidic rites of ancient Britain.

Thus we may give with a bouqnet memories of mythology, history, nsefulness, beauty, and fragrance ; and in modern times we have added to the ancient claims of flowers that of language-a gift bestowed on them by the East, and transplanted thence by one of the most gifted of Englishwomen, Lady Mary Wortley Montagu.

In our Floral Gift we have endeavored to unite all this goodly heritage of flower-land. And with these few lines of introduction, we leave them to their worthy chroniclers-the Poets. 


\section{DAISY.}

\section{(Innocence.)}

"Whose white investments figure innocence."-SHAKsPEARE.

rTHE flower which, next to the rose, appears to have 1 received the most attention from the poets is the Daisy.

Formerly it was termed the "e'e of daie," and under that name Chaucer speaks of it.

According to the classic account, this little flower owed its origin to Belides, one of the dryads, the nymphs who presided over woodlands. It is fabled that whilst this damsel was dancing with her favored suitor, Ephigeus, she attracted the attention of Vertumnus, the guardian deity of orchards: and it was in order to shelter her from his pursuit that she was transformed into Bcellis, or the daisy - the "day's eye," as our old poets call it-the flower of faithful love, which opens and closes with the sun.

It is called in French la Marguerite, or pearl.

The unhappy Margaret of Anjon chose it as her device; and when she reigned a beauty and crowned queen, the nobles of England wore wreaths of it, or had it embroidered on their robes.

Marguerite de Valois, the friend of Erasmus and Calvin-the Marguerite of Marguerites-also adopted this flower as her device; and it was more appropriate certainly to the princess who withdrew from the glitter of courts to study her Bible than to the ambitious Lancastrian queen of England. 


\section{THẼ DAISIE.}

\section{CHAUCER.}

DAISIE of light! very ground of comfort? The summis donghtir ye hight, as I rede, For when he westrith, farwell your disport; By your nature anone, right for pure drede Of the rnde Night, that with his boistous irede Of derkenesse shadowith our hemisphere, Then closin ye, my liv'is ladie dere.

Damnying the daic nnto his kind resort, And Phoebus your fethir with his stremes rede Adorneth the morrowe, consuming the sort Of mistic eloudes, that wouldin ovirlede True humble hertis with ther mistie hede, Nere comfort adaies, when your eyin clere Diselosc and sprede, my liv'is lade dere.

Je vouldray; but the grete God disposeth And makith easmell by His providence Soche thing as mannis frele wit purposeth, All for the best, if trat your conseience Not grutclie it, but in humble pacienee It reecve; for God saith withontin fable, A faithfull herte evir is acceptable.

\section{From "A Godely Balade."}

\section{TO THE DAIST.}

WORDSWORTI.

Brrght flower! whose home is everywhere, Bold in maternal Nature's care, And all the long year throngh the heir Of joy or sorrow; 
Methinks that there abides in thee

Some coneord with humanity,

Given to no other flower I see

'The forest thorough!

Is it that man is soon deprest?

A thoughtless thing? who, onee umblest, Does little on his memory rest,

Or on his reason,

And thou wouldst teach him how to find

A shelter under every wind,

$\Lambda$ hope for times that are unkind,

And every season?

Thou wander'st the wide world about, Uneheck'd by pride or serupulous doubt, With friends to greet thee, or without,

Yet pleased and willing;

Meek, yiclding to the occasion's call, And all things suffering from all, Thy function apostolical

In peace fulfilling.

TO A MOUNTAIN DAISY.

ON TURNING ONE DOWN WITI A PLOW.

BURNS.

WEE, modest, erimson-tipped flower,

Thou's met me in an evil lour,

For I maun erush amang the stoure*

Thy slender stem ;

To spare thee now is past my power.

Thou bounie gem. 
Alas ! it's no thy neebor sweet, 'The bonnie lark, companion meet, Bending thee 'mang the dewy weet,*

Wi' speckled breast,

When upward springing, blithe to greet

The purpling east.

Cauld blew the bitter, biting north Upon thy early, humble birth ;

Yet cheerfully thou glinted forth

Amid the storm,

Searee reared above the parent earth

Thy tender form.

The flaunting flowers our gardens yield, Iigh sheltering woods and wa'sł maun shield, But thou, beneath the random bield $\S$

$O^{\prime}$ clod or stane

Adorns the histie stibble-field,

Unseen, alane.

There, in thy scanty mantle clad, Thy snawic bosom sunward spread, Thou lifts thy unassuming head

In humble guise;

But now the share uptears thy bed, And low thou lies!

Such fate to suffering worth is given,

Who lang with wants and woes has striven, By human pride or eunning driven

'To misery's brink,

Till, wrenched of every stay but Heaven, IIe ruined, sink !

$\begin{array}{ll}* \text { Weet, rain, wetness. } & \ddagger \text { Glinted, peeped. } \\ \uparrow W a \text {, walls. } & \S \text { Random bield, casual shelter. }\end{array}$


Even thou, who mourn'st the daisy's fate That fate is thine-no distant date;

Stern Ruin's plowshare drives clate

Full on thy bloom,

Till, crushed bencath the furrow's weight,

Shall be thy doom!

\section{SNOWDROP: \\ - $\mathrm{OR}$, \\ FAIR MAID OF FEBRUARY. \\ (Friend in Need-IIope.)}

THE snowdrop is dedicated to the Virgin Mary:

$\perp$ and tradition asserts that it blooms on the second of Fcbruary, or Candlemas Day-the day kept in colebration of the IIoly Virgin taking the Child Jesus to the Jewish Temple, and there presenting the appointed offering of two turtle doves.

\section{THE SNOWDROP.}

WESTWOOD.

THE snowdrop is the herald of the flowers, Sent with its small white flag of truce to plead For its beleaguered brethren : suppliantly, It prays stern winter to withdraw his troop $\mathrm{Of}$ winds and blustering storm; and having won $\Lambda$ smile of promise from his pitying face, Returns to tell the issue of its errand, To the expectant host. 


\title{
TIIE SNOWDROP.
}

\author{
WORDSWORTII.
}

LoN flower, hemmed in with snows, and white as they, But hardier far, once more I see thee bend 'Thy forehead, as if fearful to offend, Like an unbidden guest. Though day by day Storms, sallying from the mountain tops, waylay The rising sun, and on the plains descend, Yet art thou welcome, welcome as a friend Whose zeal outruns his promise! Blue-eyed May Shall soon behold this border thickly set With bright jonquils, their odors lavishing On the soft west wind and his frolie peers; Nor will I then thy modest grace forget, Chaste snowdrop, venturous harbinger of Spring, And pensive mouitor of fleeting years!

\section{THE SNOWDROP.}

MRS. HOWITT.

THE snowdrop! 'Tis an English flower, And grows beneatl our garden trees; For every heart it has a dower, And old and dear remembranees ! All look lupon it, and straightway Recall their youth like yesterday, Their sunny years when forth they went, Wardering in measureless content; Their little plot of garden ground, The mossy orehard's quiet bound; 
Their father's house so free from care, And the familiar faccs there;

The household voices kind and sweet,

That knew no feigning-hushed and gonc!

The mother that was sure to greet

Their coming with a welcome tone; The brothers that were children then, Now anxious, toiling, thoughtful men; And the kind sistcr whose glad mirth Was like a sunshine on the earthThesc comc back to the soul supine, Flower of the spring, at look of thine : And thou, among the dimmed and gone, Art an unaltered thing alonc !

Unchanged-unchangcd-the vcry flower

That grew in Eden droopinglyAnd now beside the pcasant's door Awakes his little chlddren's glee, Even as it filled his heart with joy Beside his mother's door, a boy !The same-and to his heart it brings The freshness of thosc vanished springs! Bloom then, fair flower, in sun and shade, For deep thought in thy cup is laid ; And careless children, in their glee, A sacred memory make of thee!

\section{TO THE SNOWDROP.}

KEBLE.

THou first-born of the year's delight, Pride of the dewy glade, 
In vernal green and virgin white, Thy vestal robes arrayed:

'Tis not because thy drooping form Sinks grateful on its nest, When chilly shades from gathering storm Affright thy tender breast;

Nor from yon river islet wild, Beneath the willow spray, Where like the ringlets of a child, Thou wearest thy circle gay;

'Tis not for these I love thee dear,Thy shy averted smiles To fancy bode a joyous year, One of life's fairy isles.

They twinkle to the wintry moon, And cheer the ungenial day, And tell us all will glisten soon, As green and bright as they.

Is there a lieart that loves the spring, Their witness can refuse?

Yet mortals doubt when angels bring From Heaven their Easter news :

When holy maids and matrons speak Of Christ's forsaken bed, And roices, that forbid to seek The living 'mid the dead; 
And when they say, "Turn, wandering heart, Thy Lord is risen indeed,

Let pleasure go, put eare apart, And to His presenee speed;"

We smile in seorn ; and yet we know They early sought the tomb, Their hearts that now so freshly glow, Lost in desponding gloom.

They who have sought, nor hope to find, Wear not so bright a glance:

They who have won their earthly mind, Less reverently advanee.

But where, in gentle spirits, fear And joy so duly meet,

These sure have seen the angels near, $\Lambda$ nd kissed the Saviour's feet.

Nor let the pastor's thankful eye

'Their faltering tale disdain, As on their lowly eoueh they lie, Prisoners of want and pain.

0 guide us, when our faithless hearts From thee would start aloof, Where patienee her sweet skill imparts Beneath some eottage roof :

Revive our drooping fires, to burn

High as her anthems soar, And of our seholars let us learn Our own forgotten lore. 


\title{
THE SNOWDROP.
}

\author{
MRS. ROBINSON.
}

The Snowdrop, Winter's timid child, Awakes to life, bedewed with tears, And flings around its fragrance mild; And, where no rival flowerets bloom Amidst the bare and chilling gloom, A beauteous gem appears. * * * * *

Where'er I find thee, gentle flower, Thou still art sweet and dear to me !

For I have known the cheerless hour, Have seen the sunbeams cold and pale, Have felt the chilling wintry gale, And wept and shrunk like thee.

\section{THE SNOWDROP.}

As Hope, with bowed head, silent stood, And on her golden anchor leant. Watching below the angry flood,

While Winter, 'mid the dreariment Half-buried in the drifted snow,

Lay sleeping on the frozen ground, Not heeding how the wind did blow,

Bitter and bleak on all around: She gazed on Spring, who at her feet Was looking at the snow and sleet. 
Spring sighed, and through the driving gale Her warm breath caught the falling snow, And from the flakes a flower as pale

Did into spotless whiteness blow; Hope, smiling, saw the blossom fall, And watched its root strike in the earth,"I will that flower the Snowdrop call," Said Hope, "in memory of its birth ; And through all ages it shall be In reverence held, for love of me."

"And ever from my hidden bowers," Said Spring, "it first of all shall go, And be the lierald of the flowers,

To warn away the sheeted snow :

Its mission done, then by thy side

All summer long it shall remain. While other flowers I scatter wide

O'er every hill, and wood, and plain, This shall return, and ever be A sweet companion, Hope, for thee."

Hope stooped and kissed her sister Spring, And said, "For hours when thou art gone, I'm left alone without a thing That I can fix my heart upon, 'Twill cheer me many a lonely hour,

And in the future I shall see

Those who would sink, raised by that flower,

They'll look on it, then think of thee ;

And many a weary heart shall sing, The Snowdrop bringeth Hope and Spring. 


\section{THE COWSLIP. \\ (Pensiveness-Winning Touthful Grace.)}

THE "pretty Mullein," as it is called, is one of the 1 sweetest of our meadow flowers. The yellow oxlip is larger, and not quite so common.

Cowslip wine is pleasant, and said to be slightly narcotic.

Shakspeare, speaking of the Fairy Queen, says :

"The eowslips tall her pensioners be ;

In their gold eoats spots we see;

Those be rubies, fairy farors, -

In those freekles live their savors;

I must go seek some dewdrops here, And hang a pearl in every cowslip's ear."

Milton, in his masque of "Comus," has given an exquisite song to Sabrina, in which the airy tread of that goddess "o'er the cowslip's velvet head" is most delicately expressed :

" By the rushy, fringèd bank, Where grow the willow and the osier dank,

My sliding ehariot stays ;

Thiek set with agate and the azure sheen

of turkis blue and emerald green,

That in the channel strays ;

Whilst from off the waters fleet,

Thus I set iny printless feet,

O'er the eowslip's velvet head,

That bends not as I tread.

Gentle swain, at thy request

I am here," 
These flowers furnish an abundant supply of honey to the bee; for

" Rich in vegetable gold, From calyx pale the freckled cowslip born, Receives in amber cups the fragrant dews of moru.'

\section{THE COWSLIP.}

MIRS. SIGOURNEY.

GooD neighbor cowslip, I have seen the bee Whispering to you, and have been told he stays Quite long and late amid your golden cells. Is it not business that he comes uponMatter of fact? He never waits an hour. Know you that he's a subtle financier, And shows some gain for every day he spends? Oh! learn from him the priceless worth of time, Thou fair and frail ! So shalt thou prove the truth, That he who makes companion of the wise Shall in their wisdom share.

\section{COWSLIPS:}

MARY HOWITT.

Он ! fragrant dwellers of the lea, When first the wildwood rings With each sound of vernal minstrelsy, When fresh the green grass springs! 
What can the blessed spring restore More gladdening than your charms, Bringing the memory once more Of lovely fields and farms !

Of thiekets, breezes, birds, and flowers ; Of life's unfolding prime; Of thoughts as eloudless as the hours; Of souls without a erime.

Oh! blessed, blessed do ye seem, For, even now, I turned With soul athirst for wood and stream, From streets that glared and burned.

From the hot town, where mortal care

His crowded fold doth pen; Where stagnates the polluted air In many a sultry den.

And are yo here? and are ye here?

Drinking the dew like wine, 'Midst living gales and waters clear, And heaven's unstinted shine.

I eare not that your little life Will quiekly have run through, And the sward with summer ehildren rife Keep not a traee of you.

For again, again, on dewy plain, I trust to see you rise, When spring renews the wildwood strisin, And bluer glemm the skies. 
Again, again, when many springs

Upon my grave shall shine,

Here shall you speak of vanished things

To living hearts of mine.

THE COWSLIP.

MIISS LANDON.

THE cowslip, that bending

With its golden bells, Of each glad hour's ending

With a sweet chime tells.

\section{CROCUS.}

(Cheerfulness-Hope.)

A CCORDING to some authol's, these bright little A flowers, which

"Come before the swallow dares, And take the winds of March with beauty,"

derive their name from a Greek word signifying thread, from the fact of their thread or filament being in such request for saffron dye.

The Greeks fabled that Crocu, a beautiful youth, was transformed into this flower; as his lady-love, Smilax, was at the same time into a yew-tree.

It is in England consecrated to St. Valentine. 
Bees are excessively fond of the crocus; and Moore thus alludes to this fact in "Lalla Rookh":

"The busicst hive

On Bela's hills is less alive,

When saffron-beds are full in flower, Than looked the valley in that hour."

Mrs. Howitt says of the purple crocus :

"Like lilac flame its color glows,

Tender and yet so clearly bright, That all for miles and mules about The splendid meadow shineth out, And far-off village children shout

To see the welcome sight."

TO A CROCUS.

BLOOMING BENEATH A WAILFLOWER.

BARTON.

WeLCoMe, wild harbinger of spring!

To this small nook of earth ;

Feeling and fancy fondly eling

Round thoughts which owe their birth

To thee, and to the humble spot

Where chance has fixed thy lowly lot.

To thee,-for thy rich golden bloom,

Lilie heaven's fair bow on high,

Portends, amid surrounding gloom,

That brighter hours draw nigh,

When blossoms of more varied dyes

Shall ope their tints to warmer skies. 
Yet not the lily, nor the rose,

Though farrer far they be,

Can more delightful thoughts disclose

Than I derive from thee :

The eye their beauty may prefer;

The heart is thy interpreter!

Methinks in thy fair flower is seen,

By those whose faneies roam,

An emblem of that leaf of green

'The faitluful dove brought home,

When o'er the world of waters dark

Were driven the inmates of the ark.

That leaf betokened freedom nigh

To mournful eaptives there;

Thy flower foretells a sunnier sky,

And ehides the dark despair,

By winter's chilling influence flung

$O^{\prime} e r$ spirits sunk, and nerves unstrung.

And sweetly has kind Nature's hand

Assigned thy dwelling-plaee

Beneath a flower whose blooms expand

Wilh fond congenial graee,

On many a desolated pile,

Brightening deeay with beauty's smile.

Thine is the flower of Hope, whose hue

Is bright with coming joy ;

The wallflower's that of Faith, too true

For ruin to destroy ;-

And where, O! where should Hope up-spring

But under Faith's protecting wing. 
TO THE CROCUS.

PATTERSON.

LowLy, sprightly little flower !

Herald of a brighter bloom,

Bursting in a sunny hour

From thy winter tomb.

Hues you bring, bright, gay, and tender,

As if never to decay;

Fleeting in their varied splendor-.

Soon, alas! it fades away.

Thus the hopes I long had cherished Thus the friends I long had known, One by one, like you, have perished, Blighted-I must fade alone.

\section{APPLE-BLOSSOM.}

(Preference.)

TN the Scandinavian mythology the apple-tree played 1 an important part. In the "Edda," the goddess Iduna is related to have had charge of the apples which had the power of conferring immortality, and which, in consequence of their miraculous property, were especially retained for the gods to eat when they felt themselves growing old. The evil spirit, Loki, carried off Iduna and the wonderful apple-tree, and hid 
them away in a forest where the deities were unable to find them. The results of this spiteful theft were that everything went wrong, both in the realms mundane and divine. The gods grew old and infirm, and, beeoming enfeebled in mind and body, were no longer able to regulate the affairs of the earth; and mortals, no longer having any one to look after them, fell into evil ways, and beeame a prey to the evil spirit. Affairs grew worse daily, until the gods, eombining the remains of their strength, overeame Loki, and compelled him to restore the stolen apple-tree.

\section{APPLE-BLOSSOMS.}

L. E. L.

OF all the months that fill the year

Give April's month to me,

For earth and sky are then so filled

With sweet variety!

The apple-blossoms' shower of pearl,

Though blent with rosier hue--

As beautiful as woman's blush,

As evanescent too.

On every bough there is a bud,

In every bud a flower;

But searcèly bud or flower will last

Beyond the present hour.

Now comes a shower eloud o'er the sky,

Then all again sunshine; 
Then clouds again, but briglitened with The rainbow's colored line.

Ay, this, this is the month for me !

I could not love a scene

Where the blue sky was always blue, The green earth always green.

TO BLOSSOMS.

HERRICK.

Fair pledges of a fruitful tree, Why do you fall so fast?

Your date is not so past;

But you may stay here yet awhile, To blush and gently smile, And go at last.

What, were ye born to be An hour or lialf's delight, And so to bid good night? 'Twas pity Nature brought ye forth, Merely to show your worth, And lose you quite.

But you are lovely leares, where we May read how soon things have Their end, though ne'er so brave : And after they have shown their pride Like you awhile, they glide Into the grave. 


\section{DAFFODIL.}

\section{(Unrequited Love.)}

THE name of this flower is only a corruption of 1 Dis's lily, as it is supposed to be the flower that dropped from Pluto's clariot when he was carrying off Proserpine to the infernal regions. Jean Ingelow, in the beautiful poem of "Persephone," thus introduces this flower into a resuscitation of the antique fable:

"She stepped upon Sicilian grass,

Demeter's daughter fresh and fair, A child of light, a radiant lass,

And gamesome as the morning air.

The daffodils were fair to see,

They nodded lightly on the lea.

"Lo! one she marked of rarer growth

Than orchis or anemone ;

For it the maiden left them both,

And parted from her company.

Drawn nigh, she deemed it fairer still, And stooped to gather by the rill

The daffodil, the daffodil.

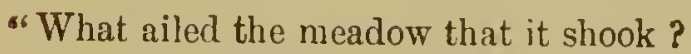

What ailed the air of Sicily?

She wondered by the brattling brook,

And trembled with the trembling lea.

'The coal-black horses rise-they rise!

O mother, mother!" low she cries.

" ' $O$ light, $O$ light !' she cries, 'farewell ;

The coal-black horses wait for me.

$O$ shade of shades, where I must dwell,

Demeter, mother, far from thee ! 
Oh, fated doom that I fulfill !

Oh, fateful flower beside the rill!

'The daffodil, the daffodil !'"

Chancer alludes to this story, and Shakspeare introduces it into his "Winter's Tale :"

"O Proserpina,

For the flowers now that, frighted, thou lett'st fall

From Dis's wagon: daffodils

That come before the swallow dares, and take

The winds of March with beauty."

\section{DAFFODILS.}

HERRICK.

Fair daffodils, we weep to see

Ye haste away so soon ;

As yet the early-rising sun

Has not attained his noon :

Stay, stay,

Until the hastening day

Has run

But to the even-song,

And, having prayed together, we

Will go with ye along.

We have short time to stay as ye,

We have as fleet a Spring, As quick a growth to meet decay

As you or anything:

We die

As your hours do and dry

Away 


\section{Like to the summer's rain, Or as the pearls of morning's dew, Ne'er to be found again.}

\section{DAFFODILS.}

WORDSWORTH.

I WANDERED lonely as a eloud 'That floats on high o'er vales and hills, When all at once I saw a crowd, A host of golden daffodils, Beside the lake, beneath the trees, Fluttering and dancing in the breeze.

Continuous as the stars that shine And twinkle in the milky-way, They stretehed in never-ending line Along the margin of a bay. Ten thousand saw I at a glance, Tossing their heads in sprightly dance.

The waves beside them daneed; but they Ontdid the sparkling waves in glee :

A poet could not but be gay,

In such a jocund eompany ;

I gazed-and gazed-but little thought What wealth the show to me had brought:

For oft when on my eouch I lie, In vacant or in pensive mood, They flash upon that inward eye Which is the bliss of solitude; And then my heart with pleasure fills, And danees with the daffodils. 


\section{VIOLET.}

(Modesty.)

"The violet is for modesty."-Burns.

TIOLETS, considered by some as typical of modesty, by other's are deemed emblematic of faithfulness; and the latter have the support of one of Shakspeare's contempolary poets :

"Violet is for faithfulness,

Which in me shall abide;

Hoping likewise that from your heart

You will not let it slide."

"The violet was as proud a deviee of the Ionic Athenians," says a well-known author, "as the rose of England and the lily of Franee. In all seasons it was to be seen exposed for sale in the market-plaee at Athens, the eitizens being suceessful in rearing it in their gardens even when the ground was eovered with snow."

The Greeks called this flower "Ion," and it was said that Jupitel caused the first violet to spring up in the grass, when the unhappy Io, metamorphosed into a herfer, vent her lips to eat.

Perdita, when wishing for flowers to give her guests, in the "Winter's Tale," thus speaks of the beauty and perfume of violets :

"Violets dim,

But sweeter than the lids of Juno's eyes,

Or Cytherea's breath."

The frequent allusions made to " the nodding violet" by our great dramatist cause it to be regarded as his 
favorite flower ; and in the eyes of many, the fact will not be one of its slightest charms. There is not a more exquisite passage in the whole range of English poetry than that in "Twelfth Night," where the Duke, listening to plaintive music, desires

"That strain again ; it had a dying fall :

Oh, it came o'er my ear' like the sweet South

That breathes upon a bank of violets,

Stealing and giving odor."

Shakspeare employs his beloved flower as the type of modesty and maidenhood. Indeed, poets are continually using this retiring blossom as an emblem of those qualities.

"She steals timidly away,

Shrinking as violets do in Summer's ray."-Moore.

Barry Cornwall gives it the preference over the rose:

"The king told Gyges of the purple flower ;

It chanced to be the flower the boy liked most :

It has a scent as though Love, for its dower,

Had on it all his odorous arrows tost :

For though the rose has more perfuming power

The violet-haply 'cause 'tis almost lost,

And takes us so inuch trouble to discover-

Stands first with most, but always with a lover."

"No flowers grew in the vale,

Kissed by the dew, wooed by the gale-

None by the dew of the twilight wet,

So sweet as the deep blue violet."-L. E. L.

"When the grave shall open for me-

I care not how soon that time may be- 
Never a rose shall grow on that tomb, It breathes too much of hope and blnom: But there be that flower's meek regret, The bending and deep blue violet."-L. E. L.

Whilst the first Napoleon was in exile, this little blossom was adopted by his followers as an emblem; he was styled Père la Violette, and a small bunch of violets hung up in the house, or worn by a Frenchman, denoted the adherence of the wearer to his fallen chieftain's cause. It is still the emblem of the Bonapartes.

The White Violet, which is not invariably scentless, as is sometimes erroneously presumed, is emblematic of candor, although some authors adopt it as the representative of innocence.

TO A FADING VIOLET.

SHELLEY.

THE color from the flower is gone,

Which like thy sweet eyes smiled on me;

The odor from the flower is flown,

Which breathed of thee, and only thee!

A withered, lifeless, vacant form,

It lies on my abandoned breast,

And mocks the heart which yet is warm,

With cold and silent rest.

I weep-my tears revive it not;

I sigh-it breathes no more on me;

Its mute and uncomplaining lot

Is such as mine should be. 


\section{VIOLETS.}

\section{J. MOULTRIE.}

UNDER the green hedges after the snow, There do the dear little violets grow, Hiding their modest and beautiful heads Under the hawthorn in soft mossy beds.

Sweet as the roses, and blue as the sky, Down there do the dear little violets lie, Hiding their heads where they scarce may be seen ; By the leaves you may know where the violet hath been.

\section{THE ALPINE VIOLET.}

BY IJORD BYRON.

THe Spring is come, the Violet's gone, The first-born child of the early sun;

With us she is but a winter flower,

The snow on the hills cannot blast her bower;

And she lifts up her dewy eye of blue

To the youngest sky of the self-same hue.

But when the Spring comes with her host Of flowers, that flower, beloved the most, Shrmks from the crowd, that may confuse Her heavenly odors and virgin hues.

Pluck the others, but still remember Their herald, out of dire December ; 
The morning star of all the flowers, The pledge of daylight's lengthen'd hours, And 'mid the Roses, ne'er forget The virgin, virgin Violet.

\section{THE ANGRY VIOLETS.}

DRAYTON.

The pansy and the violet here, As seeming to descend Both from one root, a very pair, For sweetness do contend.

And pointing to a pink to tell

Which bears it, it is loth To judge it ; but replies, for smell, That it excels them botl.

Wherewith displeased they hang their heads, So angry soon they grow, And from their odoriferous beds

Their sweets at it they throw.

\section{VIOLETS.}

MISS LANDON.

I Do love violets.

They tell a history of woman's love ;

They open with the earliest breath of spring;

Lead a sweet life of perfume, dew, and light, 
And if they perish, perish with a sigh Delicious as that life. On the hot June They shed no perfume; the flowers may remain, But the rich breathing of their leaves is past; Like woman, they have lost their loveliest gift When yiclding to the ficry hour of passion.

-The violet-breath of love is purity.

\section{A BOUQUET OF SPRING VIOLETS.}

\section{SHELIET.}

After the slumber of the year The woodland violets reappear ; All things revive in field and grove, And sea and sky; but two, which move And form all others, life and love.

\section{A VIOLET BANK.}

SH AKSPEARE.

I kNow a bank whereon the wild thyme blows, Where oxlips and the nodding violet grows : Quite over-canopied with lush woodbine, With sweet musk roses and with eglantine.

\section{THE VIOLET.}

FROM THE GERMAN OF GOETHE.

A Violet blossom'd on the green, With lowly stem, and bloom unseen; 
It was a sweet, low flower.

A shepherd maiden came that way, With lightsome step and aspect gay,

Came near, came near,

Came o'er the green with song.

Ah ! thought the Violet, might I be The fairest flower on all the lea,

Ah! but for one brief hour :

And might be plucked by that dear maid, And gently on her bosom laid,

Ah! but, ah ! but

A few dear moments long.

Alas! the maiden, as she pass'd,

No eye upon the Violet cast;

She crush'd the poor wee flower ;

It sank, and, dying, heaved no sigh,

And if I die, at least I die

By her, by her,

Beneath her feet I die.

\section{THE YELLOW VIOLET.}

BRYANT.

WHEN beechen buds begin to swell,

And woods the blue-bird's warble know,

The yellow violet's modest bell

Peeps from the last year's leaves below.

Ere russet fields their green resume,

Sweet flower, I love, in forest bare, To meet thee, when thy faint perfume

Alone is in the virgin air. 
Of all her train, the hands of Spring

First plant thee in the watery mold: And I have seen thee blossoming

Beside the snow-bark's edges cold.

Thy parent sun, who bade thee view

Pale skies, and chilling moisture sip,

Has bathed thee in his own bright hue, And streaked with jet thy glowing lip.

Y t slight thy form, and low thy seat, And earthward bent thy gentle eye,

Unapt the passing view to meet,

When loftier fowers are flaunting nigh.

Oft, in the sunless April day,

Thy early smile has stayed my walk;

But 'midst the gorgeous blooms of May,

I passed thee on thy humble stalk.

So they, who climb to wealth, forget

The friends in darker fortunes tried,

I copied them - but I regret

That I should ape the ways of pride.

And when again the genial hour

A wakes the painted tribes of light,

I'll uot o'erlook the modest flower

'Ihat made the woods of April bright. 


\section{NARCISSUS.}

\section{(Self-love.)}

THE white or poetieal Narcissus is adopted as the 1 emblem of egotism, beeause, aecording to the mythologists, it owes its origin to a beautiful youth of Bœotia, of whom it had been foretold that he should live happily until he beheld his own faee. One day, when heated by the chase, Nareissus sought to queneh his thirst in a stream; in so doing he beheld the reflcetion of his own features, of which he immediately became enamored. He was spellbound to the spot, where he pined to death, and was metamorphosed by the gods into the flower that now bears his name. When the Naiads had prepared the funeral pile for Nareissus, his body was missing :

"Instead whereof a yellow flower was found, With tufts of white about the button crowned ;"

and ever since is seen

"Narcissus fair, As o'er the fabled fountain hanging still."

The poetic Nareissus has a snow-white flower, with a yellow eup in the eenter, fringed on the border with a brilliant crimson circlet. It is sweet scented, and 
flowers in May. The cup in the center is supposed to contan the tears of th: ill fated Narcissus. Keats terms it "a lovily flower: :"

"A meek and forlorn flower, with nought of pride."

And Shelley speaks thus of it:

" The pied windflowers and the tulip tall, And Nareissi, the fairest among them all, Who gaze on their eyes in the stream's recess, Till they die at their own dear loveliness."

\section{ECHO AND NARCISSUS.}

\section{MILTON.}

SweET Echo, streetest nymph, that liv'st unseen

Within thy airy shell,

By slow Meander's margent green, And in the violet-embroidered vale,

Where the love-lorn nightingale Nightly to thee her sad song mourneth well; Canst thou not tell me of a gentle parr

That likest thy Narcissus are?

$$
0 \text {, if thou have }
$$

Hid them in some flowery cave,

Tell me but where,

Sweet queen of parley, daughter of the sphere,

So mayest thou be translated to the skies, And give resounding grace to all heaven's harmonies. 


\section{NARCISSUS.}

LET long-lived pansies here their scents bestow, The violet languish, and the roses glow; In yellow glory let the crocus shine, Nareissus liere his lore-sick head recline; Here hyacinths in purple sweetness rise, And tulips tinged with beauty's fairest dyes.

\section{TO A MIIRROR.}

\section{FROM GARCILASO DE IA VEGA.}

Since still my passion-pleading strains

Have failed her heart to move, Show, mirror, to that lovely maid, The charms that make me love.

Reflect on her the thrilling beam Of magie from her eye; So, like Nareissus, she shall gaze, And, self-enamored, dic.

\section{DEATH OF NARCISSUS.}

ADDISON.

THEN on th' mnwolesome earth he gasping lies, Till death shuts up those self-admiring cyes. 
To the cold shades his flitting ghost retires, And in the Stygian waves itself admires.

For him the Naiads and the Dryads mourn, Whom the sad Eeho answers in her turn: And now the sister nymphs prepare his urn; When, looking for his corpse, they only found A rising stalk, with yellow blossoins crowned.

\section{NARCISSUS.}

I sAw the pride of all the meadow At morn, a gay Nareissus blow Upon a river's bank, whose shadow Bloomed in the silver waves below. By noontide's heat its youth was wasted, 'The waters as they passed eomplained; At eve its glories all were blasted, And not one former graee lemained.

\section{TO THE NARCISSUS.}

\section{BEN JONSON.}

ARIsE, and speak thy sorrows, Eeho, rise; Here, by this fountain, where thy love did nine, Whose memory lives fresh to vulgar fame, Shrined in this yellow flower, that bears his name. 
ЕСHO.

His name revives, and lifts me up from earth ; See, see, the mourning fount, whose springs weep yet, Th' untimely fate of that too beauteous boy, That trophy of self-love, and spoil of nature, Who (now transformed into this drooping flower) Hangs the repentant head back from the stream : As if it wished,-would I had never looked In such a flattering mirror! O Nareissus! Thou that wast once (and yet art) my Narcissus, Had Echo but been private with thy thoughts, She would have dropt away herself in tears, Till she had all turned waste, that in her (As in a truer glass) thou mightst have gazed, And seen thy beauties by more kind reflection. But self-love never yet could look on truth, But with bleared beams; sliek flattery and she Are twin-born sisters, and do mix their eyes, As if you sever one, the other dies. Why did the gods give thee a heavenly form And earthly thoughts to make thee proud of it? Why do I ask? 'Tis now the known disease That beauty hath, to bear too deep a sense Of her own self-eoneeived excellence.

On hadst thou known the worth of Heaven's rieh gift, Thou wouldst have turned it to a truer use, And not (with starved and covetous ignorance)

Pined in contınual eyeing that bright gem The glance whereof to others had been more Than to thy famished mind the wide world's store. 


\section{THE NARCISSUS.}

KEATS.

What first inspired a bard of old to sing Narcissus pining o'er the untainted spring?

In some delicious ramble he had found

A little space, with bonghs all woren round And in the midst of all a clearer pool Than ere reflected in its pleasant cool

The blue sky, here and there serenely peeping, Through tendril wreaths fantastically creeping.

And on the bank a lonely flower he spied.

A meek and forlorn flower, with nought of pride, Drooping its beauty o'er the watery clearness, To woo its own sad image into nearness :

Deaf to light Zephyrus it would not move, But still would seem to droop, to pine, to love. So while the poet stood in this sweet spot, Some fainter gleamings o'er his fancy shot; Nor was it long ere he had told the tale Of young Narcissus, and sad Echo's wail.

\section{THE NARCISSUS.}

\section{GAY.}

Here young Narcissus o'er the fountain stood, And viewed his image in the crystal flood; The crystal flood reflects his lovely charms, And the pleased image strives to meet his arms. No nymph his inexperienced breast subdued, Echo in vain the flying boy pursued. Himself alone, the foolish youth admires, And with fond look the smiling shade desires; 
O'er the smooth lake with fruitless tears he grieres; His spreading fingers shoot in verdant leaves; Through his pale veins green sap now gently flows, And in a short-lived flower his beauty blows. Let vain Narcissus warn each female breast, That beauty's but a transient good at best; Like flowers it withers with th' advancing year, And age like winter robs the blooming fair.

\section{THE NARCISSUS.}

MISS LANDON.

ThE pale and delicate Narcissus' flowers Bending so languidly, as still they found In the pure wave a love and destiny.

\section{BUTTERCUPS.}

\section{(Riches-Memories of Childhood.)}

REAUTIFULLY does the great poet, Robert 1 Browning, call these emblems of riches, "the butlercups, the little children's dower."

\section{BUTTERCUPS.}

EIIZA COOK.

'T'Is sweet to love in childhood, when tle souls that we beqneath

Are beautiful in freshness as the coronals we wreathe : 
When we feed the gentle robin, and caress the leaping hound,

And linger latest on the spot where buttercups are found :

When we seek the bee and ladybird with laughter, shout, and song,

And think the day for wooing them can never be too long.

Olı ! 'tis sweet to love in childhood, and though stirred by meanest things,

'The music that the heart yields then will never leave its stings.

'Tis sweet to love in after years the deal' one by our side;

To dote with all the mingled joys of passion, hope, and pride ;

To think the chain around our breast will hold still warm and fast,

And grieve to know that death must come to break the link at last.

But when the rainbow span of bliss is waning, hne by hue ;

When eyes forget their kindly beams, and lips become less true ;

When stricken hearts are pining on through many a lonely hour,

Who would not sigh ' 'tis safer far to love the bird and flower?'

'Tis sweet to love in ripened age the trumpet blast of Fame,

To pant to live on Glory's scroll, though blood may trace the mame; 
'Tis sweet to love the heap of gold, and hug it to our breast,-

'To trust it as the guiding star and anchor of our rest. But such devotion will not serve-however strong the zeal-

To overthrow the altar where our childhood loved to kneel.

Some bitter moment shall o'ercast the sun of wealth and power,

And then proud man would fain go back to worship bird and flower.

\section{HAWTHORN.}

\section{(IIope.)}

DY the Greeks the hawthorn was deemed one of the $O$ fortunate trees. 'The Romans accounted it a symbol of marriage because it was carried at the rape of the Sabines; it was ever after considered propitious. Its flowering branches were borne aloft at their marriages, and the newly-wedded pair werc even lighted to the nuptial chamber with torches of its wood.

The Turks regard the presentation of a branch of hawthorn as donating the donor's desire to receive from the object of his affection that token of love denominated a kiss.

Ronsard-sometimes styled the French Chaucerwrotc a beantiful address to the hawthorn, thus faithfully rendered :

"Fair hawtholn flowering,

With green shute bowering 
Along this lovely shore;

To thy foot around

With his long arms wound

A wild vine has mantled thee o'er.

"In armies twain,

Red ants have ta'en

Their fortress bencetll thy stock ;

And in clefts of thy trunk

Tiny bees have sunk

A cell where honey they lock.

"In merry Spring-tide,

When to woo his bride

The nightingale comes again,

Thy boughs among

He warbles his song,

That lightens a lover's pain.

*

*ै

*

*

"Gentle hawthorn, thrive,

And, forever alive,

May'st thou blossom as now in tlyy prime;

By the wind unbroke,

And the thunder-stroke,

Unspoiled by the axe of time.'

Chancer thus sings of it :

"Furth goth all the Courte, both most and lest, T'o fetche the flouris freshe, and braunche and blome And namely hauthorne brought both page and grome, With freshe garlandis partly blew and white, And than rejoisin in their grete delight.

"Amongst the many buds proclaiming May

(Decking the meads in holiday array, Striving who shall surpass in bravery)

Mark the fair blooming of the hawthorn tree;

Who, finely clothèd in a robe of white, -

Feeds full the wanton eye with May's deliglit, 
Yet for the bravery that she is in

Doth neither handle card nor wheel to spin, Nor changeth robes but twice ; is never seen In other colors than in white or green.

Learn then, content, young shepherd, from this tree, Whose greatest wealth is Nature's livery."

Spenser tells us in his "Shepherd's Calendar,"

"Youth's folk now flocken everywhere, To gather May-baskets and smelling breere; And home they hasten the posts to dight, And all the kirk-pillars ere daylight, With hawthorn-buds, and sweet eglantine, And garlands of roses, and sops-in-wine."

Herrick, in his "Hesperides," has a beautiful idyl descriptive of the manner in which maids went a-Maying.

\section{GOING A-NIAYING.}

JOHN INGRAM.

$\mathrm{OH}$, we will go a-Maying, love, A-Maying we will go,

Beneath the branches swaying, love,

With weight of scented snow.

Laburnum's golden tresses, love,

Float in the perfumed air ;

Which heedless their caresses, love,

Seeks violets in their lair ;

And with their scents a-playing, love,

It gambols to and fro-

Where we will go a-Maying, love,

Where we will Maying go. 
The bees are busy humming, love, Amid the opening blooms,

Foretelling Summer's eoming, love-

Farewell to wintry glooms.

The primrose pale, from erinkly sheen,

Up from the ground now speeds;

And cowslips slim, 'mid leafy green,

Rise in the unknown meads.

And buttereups are weighing, love,

The gold they soon must strow-

Where we will go a-Maying, love,

Where we will Maying go.

The hawthorn's bloom is falling, love,

We must no longer wait;

Each bird is blithely calling, love,

Unto his ehosen mate;

Each bud unblown is swelling, love,

Green grow the vernal fields;

Each inseet leaves its dwelling, love,

And all to Summer yields:

The mowers are out haying, love,

Woodbine is in full blow-

Where we will go a-Maying, love,

Where we will Maying go.

\section{GOING A-MAYING.}

\section{ELIZA COOK.}

My own land! my own land! where freedom finds her throne-land;

Fair thou art, and rare thou art, to every true-born son. 
Though no gold are veins thee, though no grape-juice stains thee,

We've harvest fields, and quartered shields, well kept and nobly won.

And we have pleasant tales to tell, And spot in many a native dell, Which we may prize and love as well

As Troubadour his story.

The lilting troll and roundelay

Will néver, never pass away,

That welcomed in the herald day

Of Summer's rosy glory.

And goodly sight of mirth and might, In blood that gained us Cressy's fight,

Was hearts and eyes, all warm and bright

About the high and gay pole;

When flower bedight, 'mid leares and light, Shouts eehoed-as it reared upright-

Of "Hurrah for merry England, and the raising of the Maypole!"

When the good old times had carol rhymes,

With morris games and village ehimes;

When elown and priest shared eup and feast,

And the greatest jostled with the least,

At the "raising of the Maypole!"

My brave land ! my brave land! oh ! mayest thou be my grave-land ;

For firm and fond will be the bond that ties my heart to thee.

When Summer's beams are glowing, when Autumn's gusts are blowing,

When Winter's elouds are snowing, thou art still right dear to me. 
But yet, methinks, I love thee best

When bees are nurst on whitethorn breast, When Spring-tide pours in, sweet and blest, And joy and hope eome daneing ! When musie from the feathered throng Breaks forth in merry marriage song, And mountain streamlets dash along, Like molten diamonds glaneing ! Oh ! pleasant 'tis to sean the page, Rich with the theme of bygone age, When motley fool and learned sage, Brought garlands for the gay pole; When laugh and shout eame ringing out From eourtly knight and peasant lout, In "Hurrah for merry England, and the raising of the Maypole!"

When the good old times had earol rhymes, With morris games and village chimes; When elown and priest shared eup and feast, And the greatest jostled with the least, At the "raising of the Maypole!"

\section{PRIMROSE.}

(Youth.)

"The primrose I will pu', the firstling of the year."-Burss.

rTHE Primrose, emblematical of youth, has reeeived L innumerable deservedly warm eneomiums from our poets, but none sweeter than those popular lines of Carew :

"Ask me why I send you here This furstling of the infant year ; 
Ask me why I send to you

This primrose all bepearled with dew ;

I straight will whisper in your ears

'The sweets of love are washed with tears.

Ask me why this flower doth show

So yellow, green, and sickly too ;

Ask ne why the stalk is weak

And bending, yet it doth not break ;

I must tell you, these discover

What doubts and fears are in a lover."

Shakspeare, whose floral symbolism was perfect, introduces this delicate blossom into his pathetic drama of "Cymbeline," as typical of the youthful dead:

"With fairest flowers,

Whilst Summer lasts, and I live here, Fidele,

I'll sweeten thy sad grave : thou shalt not lack

The flower that's like thy face, pale primrose."

Again, in the "Winter's Tale," the grand dramatist still more exquisitely expresses his knowledge of its symbolic character :

"The pale primroses,

That die unmarried ere they can behold

Bright Phœbus in his strength."

Milton also styles this vernal bloom "the pale primrose." It was described by Carew as "the firstling of spring;" thus Burns also terms it in "The Posie," and Linnæus appropriately named it in his botanical system; whilst in his native Swedish it is known as Maj-nycklar, or the "key of May." Its English appellation is derived from primus - "the first"-and happily expresses one of its charms, and shows why it is such a meet emblem of youth.

This fragile flower is known classically as Paralusos, 
and was thus styled in commemoration of a youth so named, who pined away with grief for the loss of his betrothed, Melicerta, and was metamorphosed into

"The rathe primrose that, forsaken, dies."

It has been observed of poor Clare that his poems are as thickly strewn with primroses as the woodlands themselves. In his "Village Minstrel" he sings :

" Oh, who can speak his joys when Spring's young morn From wood and pasture opened on his view, When tender green buds blush upon the thorn, And the first primrose dips his leaves in dew ?

"And while he plucked the primrose in its pride, He pondered o'er its bloom 'tween joy and pride, And a rude sonnet in its praise he tried,

Where nature's simple way the aid of art supplied."

In another place he tells how, as a child, he rambled o'er the fields for flowers, and

"Robbed every primrose-root I met, And ofttimes got the root to set ; And joyful home each nosegay bore ; And felt-as I shall feel no more."

In the following lines the old poet, Browne, associates this flower with a scene of rustic idle thoughtlessness:

"As some wayfaring man, passing a wood, Goes jogging on, and in his mind naught hath, But how the primrose finely strews the path."

And the sketch is suggestive of Wordsworth's oftquoted idea in "Peter Bell :"

" $A$ primrose by a river's brim

A yellow primrose was to him, And it was nothing more." 


\section{THE PRIMROSE.}

MRS. HEMANS.

I SAW it in my evening walk, A little lonely flower;

Under a hollow bank it grew, Deep in a mossy bower.

An oak's gnarled root to roof the cave With gothic fretwork sprung, Whence jeweled fern, and arum-leaves, And ivy garlands hung.

And close beneath came sparkling out From an old tree's fallen shell

A little rill that elipt about The lady in her cell.

And then, methought, with bashful pride She seemed to sit and look On her own maiden loveliness, Pale imaged in the brook.

No other flower, no rival grew

Beside my pensive maid;

She dwelt alone, a eloistered nun, In solitude and shade.

No ruffling wind could reach her there;

No eye, methought, but mine,

Or the young lambs that came to drink, Had spied her secret shrine.

And there was pleasantness to me

In such belief-cold eyes

That slight dear Nature's loveliness,

Profane her mysteries. 
THE FARLY PRIMROSE.

HENRY KIRKE WHITE.

MILD offspring of a dark and sullen sire!

Whose modest form, so delicately fine,

Was nursed in whirling storms,

And cradled in the winds.

Thee, when young Spring first questioned Winter's sway ;

And dared the sturdy blusterer to the fight,

Thee on this bank he threw,

To mark his victory.

In this low vale, the promise of the year, Serene, thou openest to the nipping gale,

Unnoticed and alone,

Thy tender elegance.

So virtue blooms, brought forth amid the storms Of chill adversity; in some lone walk

Of life she rears her head,

Obscure and unobserved;-

While every bleaching breeze that on her blows,

Chastens her spotless purity of breast,

And hardens her to bear

Serene, the ills of life.

\section{PRIMROSES.}

IEATS.

A TUFT of evening primroses, O'er which the mind may hover till it dozes; 
O'er which it well might take a pleasant sleep, But that 'tis ever' startled by the leap Of buds into ripe flowers.

\section{SAD PRIIROSES.}

PIROFESSOR WILSON.

But we have daisies, whieh, like love Or hope, spring everywhere ; And primroses, whieh çroop above Some self-consuming eare.

So sad, so spiritual, so pale, Borll all too near the surow, 'They pine for that sweet southern gale, Which they will never know.

\section{TO A PRIMROSE.}

PRESENTED TO A FRIEND IN JANUARY.

CARRINGTON.

SwEET herald of the ever gentle spring, How gently waved o'er thee the winter's wing ! Around thee blew the warm Favonian gale, Devonia nursed thee in her loveliest vale; Beneath she rolled the Plym's pellucid stream, And heaven diffused around its quickening beam. But, ah! the sun, the shower, the zephyr bland, Made thee but fair to tempt the spoiler's hand. I eannot bear thee to thy bank again, And bathe thy breast in soft refreshing rain, 
Nor bid the gentle zephyr round thee play, Nor-'raptured eye thec basking in the ray; But snapped untimely from thy velvet stem, Be thou my daily care, my "bonnie gem," $\Lambda$ nd when thus severed from thy native glade, The radiance of thy cinque-rayed star shall fade, And pale decay come creeping o'er thy bloom, A sigh, dear flower, shall mourn thy early doom.

\section{TIE PRINIROSE.}

MRS. MUNTER.

TIIE sun declines, his parting ray Shall bear the cheerful light away, And on the landscape close : Then will I seek the lonely vale, Where sober erening's primrose pale To greet the night star blows.

Soft melancholy bloom, to thee I turn, with conscious sympathy, Like thee my hour is come ;

When length'ning shadows slowly Till lost in universal shade,

They sink beneath the tomb.

By thee I'll sit, and inly muse, What are the charms in life we lose

When time demands our breath. Alas! the load of lengthened age Has little can our wish engage, Or point the slaft of death. 
No. 'tis alone the pang to part

With those we love, that rends the heart;

That agony to save,

Some nameless cause in nature strives;

Like thee in shades, our hope revires,

And blossoms in the grave.

TO PRIMROSES.

ROBERT HERRICK.

Why do ye weep, sweet babes? can tears

Speak grief in you,

Who were but born

Just as the modest morn

Teemed her refreshing dew?

Alas! you have not known that shower

That mars a flower ;

Nor felt the unkind

Breath of a blasting wind;

Nor are ye worn with years;

Or warped as we

Who think it strange to see

Such pretty flowers, like to orphans young,

Speaking by tears before ye have a tongue.

Speak, whimpering younglings, and make known

The reason why

Ye droop and weep;

Is it for want of sleep,

Or childish lullaby?

Or that ye have not seen as yet

The violet?

Or brought a kiss

From that sweetheart to this? 
No, no; this sorrow, shown

By your tears shed,

Would have this lecture read:

That things of greatest, so of meanest worth,

Conceived with grief are, and with tears brought forth.

\section{A BOUQUET.}

M. E. LUEE.

Primroses,

Which when the shadows fall

Like soft dreams o'er the earth, And all around a Sabbath reigns

$\Lambda$ s at Creation's birth,

Burst the magic bonds of clay,

And greet with smiles the sun's last ray.

\section{HYACINTH. \\ PURPLE HYACINTH.}

(Sorrono-Play.)

A CCORDING to the mythologists, this fairy-like A fragile flower had its origin in the death of Hyacinthus, a Spartan youth, greatly favored by Apollo. He fell a victim to the jealous rage of Zephyrus, who, in revenge for the preference manifested for him by the Sun-god, had determined to effect his destruction. Accordingly, one day when 
Hyaeinthus was playing it quoits with his divine friend, Zephyrus blew so powerfully upon the quoit flung by Apollo that it struck the unfortunate prince on the temple and killed him, to the intense grief of his innoeent slayer. To commemorate the graee and beauty of the dead youth, Apollo, unable to restore him to life, cansed the flower whieh now bears his name to spring from his blood.

An annual solemnity, ealled Hyaeinthia, was established in Laeonia, in honor of Hyacinthus. It lasted tliree days, during which the people, to show their grief for the loss of their darling prinee, ate no bread, but fed upon sweetmeats, and abstained from adorning their hair with garlands as on ordinary oeeasions.

The following day was spent in feasting. Henee, perhaps, one of the floral meanings- "Play." The purple hyacinth signifies sorrow, as it is said to bear on its petals Apollo's lament for his friend-Ai, Ai-but we fail to traee the letters now.

An allusion to Hyaeinthus will also be reeognized in Milton's "Lycidas :"

"Like to that sanguine flower inscribed with woe."

\section{THE II $\triangle C I N T H$.}

\section{CASIMIR.}

Cirild of the Spring, thou charming flower,

No longer in confinement lie, Arise to light, thy form aiscover, Rival the azure of the sky.

* Apollo wrote on its leaves his lament, $A i, A i$. 
The rains are gone, the storms are o'er,

Winter retires to make thee way;

Come, then, thou sweetly blooming flower,

Come lovely stranger, come away.

The sun is dressed in beaming smiles,

To give thy beauties to the day:

Young zephyrs wait with gentlest gales,

'Io fan thy bosom as they play.

\section{HYACINTHUS.}

KEATS.

Or they might watch the quoit-pitchers, intent

On either side, pitying the sad death Of Hyacinthus, when the cruel breath Of Zephyr slew him ; Zephyr penitent, Who now ere Phœbus mounts the firmament, Fondles the flower amid the sobbing rain.

\section{ROSEMARY.}

(Remembrance.)

"There's rosemary for you : that's for remembrance."

SHAKSPEARE。

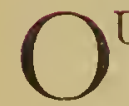

UR forefathers invariably adopted Rosemary as the symbol of remembrance; it was believed to possess the power of improving the memory, and was frequently employed as a means of invigorating the 
mental faculties. Perdita, in the "Winter's Tale," says :

"For you there's rosemary and rue ; these keep

Seeming and savor all the winter long :

Grace and remembrance be with you both !"

And in "Hamlet," Ophelia says :

" There's rosemary for you : that's for remembrance.

Pray you, lore, remember."

Miehael Drayton, in his "Pastorals," also alludes to this emblem in similar terms :

"He from his lass him lavender hath sent, Showing her love, and doth requital crave ; Him rosemary his sweetheart, whose intent Is that he her should in remembrance have."

Respeeting its employment at funerals, Mr. Martyn observes that in some parts of England, in his time, it was still eustomary to distribute it among the company, who frequently threw sprigs of it into the grave. Slips of it were also sometimes plaeed within the eoffin ; and in some seeluded villages these innoeent customs are still praeticed.

\section{TO THE IIERB ROSEMARY.}

\section{IENRY゙ LIRKE WHITE.}

SwEET scented flower ! who art wont to bloom On January's front severe, And o'er the wintry desert drear, To waft thy waste perfume! Come, thou shalt form my nosegay now, And I will bind thee round my brow, And as I twine the mournful wreath, 
I'll weare a melancholy song,

And sweet the strain shall be and long,-

The melody of death.

Come, funeral flower! who lovest to dwell

With the pale corse in lonely tomb, And throw across the deepest gloom

A sweet decaying smell.

Come, press my lips, and lie with me,

Beneath the lowly alder tree;

And we will sleep a pleasant sleep,

And not a care shall dare intrude

To break the marble solitude,

So peaeeful and so deep.

And hark! the wind god as he flies,

Moans hollow in the forest trees,

And sailing on the gusty breeze,

Mysterious music dies.

Sweet flower! that requiem wild is mine,

It warns me to the lowly shrine,

The cold turf altar of the dead;

My grave shall be in yon lone spot,

Where, as I lie, by all forgot,

A dying fragrance thou wilt o'er my ashes shed.

\section{DIE HERZ BLUME.}

\section{TOM HOOD.}

Trmene grew a little flower onee,

That blossomed in a day,

And some said it would ever bloom,

And some 'twould fade away; 
And some said it was Happiness,

And some said it was Spring,

And some said it was Grief and Tears,

And many such a thing;

But still the little flower bloomed,

And still it lived and throve,

And men do it call "Summer Growth,"

But angels call it "Love!"

\section{THE LILY OF THE VALLEY.}

\section{(Return of Happiness.)}

"Be thy advent the emblem of all I would crave."

Bernard Barton.

THE Lily of the Valley, sometimes called the May 1 Lily, and in some country villages Ladder to Heaven, in the floral languages of Europe is emblematic of the return of happiness, doubtless in allusion to the season of the year when it puts forth its blossoms.

Keats was very fond of it, and says :

"No flower amid the garden fairer grows

Than the sweet lily of the lowly vale,

The queen of flowers."

And further on

"Valley-lilies, whiter still

Than Leda's love."

In that enchanted garden where the sensitive plant grew, Shelley lovingly placed

"The naiad-like lily of the vale,

Whom youth makes so fair, and passion so paie,

That the light of its tremulous bells is seen

Through their pavilions of tender green." 


\section{THE CHIID AND THE LILY.}

\section{BRYAN'T.}

INNOCENT child and snow-white flower ? Well are ye paired in your opening hour, Thus should the pure and the lovely meet, Stainless with stainless, and sweet with sweet.

White, as those leaves just blown apart, Are the folds of thy own young heart; Guilty passion and cankering care Never have left their traces there.

Artless one! though thou gazest now O'er the white blossoms with earnest brow, Soon will it tire thy childish eye, Fair as it is, thon wilt throw it by.

Throw it aside in thy weary hour, Throw to the ground the fair white flower, Yet, as thy tender years depart, Keep that white and innocent heart.

\section{THE LILY OF THE VALLEY.}

CROLY.

WHITE bud! that in meek beauty so dost lean, The cloistered eheck as pale as moonlight snow, 'i'hou seem'st beneath thy huge high leaf of green, An Eremite beneath his mountain's brow. 
White bud ; thou'rt emblem of a lovelier thing,The broken spirit that its anguish bear.

Tc silent shades, and there sits offering 'To Heaven, the holy fragrance of its tears.

\section{THE LILY.}

\section{PERCIVAL.}

I HAD found out a sweet green spot Where a lily was blooming fair ;

The din of the city disturbed it not;

But the spirit that shades the quiet cot With its wings of love was there.

I found that lily's bloom

When the day was dark and chill :

It smiled like a star in a misty gloom,

And it sent abroad a sweet perfume,

Which is floating around me still.

I sat by the lily's bell,

And watched it many a day :-

The leaves that rose in a flowing swell,

Grew faint and dim, then drooped and fell, And the flower had flown away.

I lookec where the leaves were laid,

In withering paleness, by ;

And as gloomy thoughts stole on me, said,

'There's many a sweet and blooming maid

Who will soor as dimly die. 


\section{THE LILY.}

COLEIRIDGE.

THE stream with langud murmur creeps

In Lumin's Howery vale :

Beneath the dew the lily weeps,

Slow waving to the gale.

"Cease, restless gale !" it seems to say, "Nor wake me with thy sighing!

The hours of my vernal day On rapid wings are flying.

"To-morrow shall the traveller eome Who late beheld me blooming; His searehing eye shall vainly roam The dreary vale of Lumin."

I SEND THE LILIES GIVEN TO MIE.

BY BYRON.

I SEND the lilies given to me, Though, long before thy hand they touch, I know that they must witlered be; But yet reject them not as such : For I have cherished them as dear,

Beeause they yet may meet thine eye, And guide thy soul to mine even here,

When thou behold'st them drooping nigh, Ani know'st them gathered by the Rhine, And offered from my heart to thine! 
The river nobly foams and flows, The charm of this enchanted ground, And all its thousand turns disclose

Some fresher beauty varying round; The haughtiest breast its wish might bound,

Through life to dwell delighted liere;

Nor could on eartl a spot be found

To nature and to me so dear.

Could thy dear eyes, in follorving mine, Still sweeten more these banks of Rhine!

\section{PIMFERNEL.}

(Change.)

" More bitter far than all

It was to know that love could change and die."

A. A. Procter.

THE Pimpernel does not unfold its brilliant petals

1 until eight o'clock in the morning, and refolds them towards noon : this habit has obtained for it the cognomen of "the poor man's weather-glass;" whilst for its usefulness in foretelling the approach of rain, it is frequently known as "the shepherd's warning." Few who have passed a portion oi their life in the country but are acquainted with this property of the pretty little pimpernel. Whencrer its tiny scarlet blossoms are seen folding up their delicate petals. it may be deemed a certain indication of approaching rain ; and as such a sign Darwin notices it: 
"Closed is the pink-eyed pimpernel ;

In fiery red the sun doth rise,

Then wades through clouds to mount the skies:

"I'will surely rain, we see 't with sorrow,-

No working in the fields to-morrow."

\section{PLIPERNEL.}

O. W. HOLMES.

Some years ago, a dark-eyed maid

Was sitting in the shade-

There's something brings her to my mind

In that young dreaming maid-

And in her hand she held a flower,

A flower whose speaking hue

Said, in the language of the heart,

"Believe the giver true."

And as she looked upon its leaves,

The maiden made a vow

To wear it when the bridal wreath

Was woven for her brow.

She watehed the flower, as, day by day,

The leaflets eurled and died;

But he who gave it never eame

To elaim her for his bride.

Oh, many a Summer's morning glow

Has lent the rose its lay,

And many a Winter's drifting snow

Has swept its bloom away; 
But she has kept that faithless pledge

'I'o this her Winter hour, And keeps it still, herself alone, And wasted like the flower.

\section{HEART'S-EASE.}

OR,

PANSY.

(Think of me-Thoughts.)

"There are pansies : that's for thoughts."-SHAKSPEARE.

TTHE Heart's-ease, as its Freneh name of pansy or 1 pensée intimates, is in the language of flowers symbolieal of remembrance. It is a beautiful variety of the violet, far surpassing that flower in diversity and brillianey of eolor, but possessing little, if any, of the exquisite fragrance for which that is so rellowned.

The name given to it by the Italians is flammola, the "little flame," at least, this is an appellation with whieh I have met, and it is quite in the taste of that poetieal people. The French eall it pensée, "a thought." "There are pansies," says poor Ophelia: "that's for thoughts." Drayton, in the "Muses" Elysium," makes his nymph say-

"Amongst these roses in a row, Next place I pinks in plenty, These double daisies then for show. And will not this be dainty? 
The pretty pansy then I'll tye,

Like stones some chain enchasing;

The next to them, their near ally,

The purple violet placing.

Another of its names is "love-in-idlcness," under which it has been again celcbrated by Shakspeare.

Besides these names, this tricolored violet is also called, in various country places, "jump-up-and-kissme-quick;" " the herb Trinity;" "6 thrce-faces-undera-hood;" "kiss-me-behind-the-garden-gate;" and "cuddle-me-to-you," which secms to have been altered by time into the less vivacious request of "call-me-toyou."

\section{HEART'S-EASE.}

MARY HOWITT.

HEART'S-EASE ! one could look for half a day Upon this flower, and shape in fancy out Full twenty different tales of love and sorrow, That gave this gentle name.

\section{ORIGIN OF THE PANSY'S NAME.}

\section{("Love in Idleness.")}

Told by Oberon, King of the Fairies, to Puck.-Shakspeare.

Oberon. My gentle Puck, come hither; thou remember'st

Sincc once I sat upon a promontory,

And heard a mermaid, on a dolphin's back, 
Uttering sueh duleet and harmonious breath, That the rude sea grew eirl at her song, And eertain stars shot madly from their spheres To hear the sea-maid's music.

Puck. I remember.

Oberon. That very time I saw (but thon eouldst not) Flying between the cold moon and the earth, Cupid all armed : a eertain aim he took At a fair restal thronèd by the west; And loosed his lore-shaft smartly from his bow, As it should pieree a liundred thousand hearts. But I might see young Cupıd's fiery shaft Quenched in the ehaste beams of the wat'ry moon, And the imperial votress passed on, In maiden meditation, faney free.

Yet marked I where the bolt of Cupid fell.

It fell upon a little western flower-

Before, milk-white; now purple with love's wound,And maidens call it " Love-in-Idleness."

\section{PANSIES.}

ROBERT BUCIANAN .

"Tne lily minds me of a maiden brow," Hugh Sutherland would say ; "the marigold Is full and sunny like her yellow hair, The full-blown rose her lips with sweetness tipt; But if you seek a likeness to her eye,-Go to the pansy, friend, and find it there." "Ay, leeze me on the pansies!" Hugh would say, Hugh Sutherland, the weaver, - - he who dwelt Here in the whitewashed cot you fancy so,- 
Who knew the learnèd names of all the flowers, And recognized a lily, though its head Rose in a diteh of dull Latinity!

Pansies? You praise the ones that grow to-day Here in the garden : had you seen the plaee When Sutherland was living! Here they grew From blue to deeper blue, in midst of eaeh A golden dazzle like a glimmering star, Each broader, bigger than a silver erown; While here the weaver sat, his labor done, Watehing his azure pets and rearing them Until they seemed to know his step and touch, And stir beneath his smile like living things! The vary sunshine loved them, and would lie Here happy, eoming early, lingering late, Beeause thiey were so fair.

\section{HEART'S-EASE.}

MRS. SHERIDAN.

In gardens oft a beauteous flower there grows, By vulgar eyes unnotieed and unseen; In sweet seeurity it humbly blows, And rears its purple head to deek the green.

This flower, as Nature's poet sweetly sings,

Was onee milk white, and Heart's-ease was its name, Till wanton Cupid poised his roseate wings,

A restal's sacred bosom to inflame. 
With treacherous aim the god his arrow drew,

Which she with scy coldness did repel ;

Robounding thence with feather speed it flew,

Till on this lonely flower at last it fell.

Heart's-ease no more the wandering shepherd found;

No more the nymphs its snowy form possess;

Its white now changed to purple by Lore's wound,

Heart's-ease no more,-_'tis Love-in-idleness.

\section{HEART'S-EASE.}

ANON.

I USEn to love thee, simple flower, 'To love thee dearly when a boy;

For thou didst seem in childlood's hour,

The smiling type of childhood's joy.

But now thou only work'st my grief,

By waking thoughts of pleasures fled.

Give me, give me the withered leaf,

That falls on Autumn's bosom dead.

For that ne'er tells of what has been,

But warns me what I soon shall be;

It looks not back on pleasure's scene,

But points unto futurity.

I love thee not, thou simple flower,

For thou art gay, and I am lone;

Thy beauty died with childhood's hour-

The heart's-ease from my path is gone. 


\section{WALLFLOWER.}

(Fidelity in Misfortune.)

A COMMON garden blossom, that seldom receives A all the attention it is worthy of, is the Wallflower, symbolical of fidelity in misfortune. It was a great favorite in the Middle Ages, when troubadours and minstrels wore it as an emblem of the unchangeableness of their affection. Wallflowers belong to the Stock family; and by far the finest is the common one, which Thomson, in his "Seasons," describes as-

"The yellow wallflower, stained with iron brown."

Bernard Barton says of the wallflower :

"An emblem true thou art, Of love's enduring luster, given To cheer a lonely heart."

And elsewhere :

"To me it speaks of loveliness, That passes not with youth, Of beauty which decay can bless, Of constancy and truth.

"But in adversity's dark hour,

When glory is gone by. It then exerts its gentle power,

The scene to beautify." 


\section{THE WALLFLOWER.}

MOIR.

THE wallflower-the wallflower, How beautiful it blooms!

It gleams above the ruined tower, Like sunlight orer tombs!

It sheds a halo of repose Around the wrecks of time;-To beauty give the flaunting rose, The wallflower is sublime.

Flower of the solitary place ! Gray run's golden crown! Thou lendest melancholy grace To haunts of old renown; Thou mantlest o'er the battlement, By strife or storm decayed; And fillest up each envious rent 'Time's canker-tooth liath made.

Whither hath fled the choral band That filled the abbey's nave?

Yon dark sepulchral yew-trees stand O'er many a level grave;

In the belfry's crevices the dove Her young brood nurseth well, Whilst thou lone flower! dost shed above A sweet decaying smell.

In the season of the tulip cup, When blossoms clothe the trees, How sweet to throw the lattice up, And scent thee on the breeze! 
The butterfly is then abroad,

The bee is on the wing,

And on the hawthorn by the road

The linnets sit and sing.

Sweet wallflower-sweet wallflower !

Thiou conjurest up to me,

Full many a soft and sunny hour

Of boyhood's thoughtless glee;

When joy from out the daisies grew

In woodland pastures greell,

And summer skies were far more blue

Than since they e'er have been.

Now Autumn's pensive voice is heard

Amid the yellow bowers,

The robin is the regal bird,

And thou the queen of flowers?

He sings on the laburnum trees, Amid the twilight dim,

And Araby ne'er gave the breeze

Such scents as thou to him.

Rich is the pink, the lily gay,

The rose is summer's guest;

Bland are thy charms when these decayOf flowers, first, last, and best!

There may be gaudier on the bower,

And statelier on the tree;

But wallflower, loved wallflower,

'Thou art the flower for me : 


\section{THE WALLFLOWER.}

\section{AYON.}

Chenrful 'midst desolation's sadness-thouFair flower, art wont to grace the moldering pile, And brightly bloom o'er ruin, like a smile Reposing calm on age's furrowed browSweet monitor ! an emblem sure I see Of virtue, and of virtue's power, in thee. For though thou cheerest the dull ruin's gloom, Still when thou'rt found upon the gay parterre, There thou art sweetest-fairest of the fair ;So virtue, while it robs of dread the tomb, Shines in the crown that youth and beauty wear, Being best of all the gems that glitter there.

\section{THE NAMING OF THE WALLFLOWER.}

HERRICK.

Wнy this flower is now called so, List, sweet maids, and you shall know. Understand this firstling was Once a brisk and bonny lass, Kept as close as Danaë was, Who a sprightly springald loved; And to have it fully proved, Up she got upon a wall, 'Tempting down to slide withal ; But the silken twist untied, So she fell, and, bruised, she died. 
Jore, in pity of the deed,

And her loving, luekless speed,

I'urned her to this plant we eall

Now " the flower of the wall."

\section{FORGET-ME-NOT.}

THIS lovely little flower has a charming legend at1 tached to it. We give it in its best poetic form at once.

THE BRIDE OF THE DANUBE.

MISS PICKERSGILI.

"SEe how yon glittering wave in sportire play Washes the bank, and steals the flowers away. And must they thus in bloom and beauty die, Without the passing tribute of a sigh?"

"No, Bertha, those young flowerets there Shall form a braid for thy sumny hair;

I yet will save one, if but one

Soft smile reward me when 'tis done."

He said, and plunged into the stream-

His only light was the moon's pale beam.

"Stay! stay!" she eried-but he had caught The drooping flowers, and breathless sought

To place the treasures at the feet

Of her from whom e'en death were sweet. 
With outstretched arms upon the shore she stood, With tearful eye she gazed upon the flood, Whose swelling tide now seemed as if 'twould sever' Her faithful lover from her arms forcver. Still through the surge he panting strove to gain 'The welcome strand-but, ah ! he strove in vain!

Yet once the false stream bore him to the spot Where stood his bride in muteness of despair : And scarcely had he said, "Forget me not!" And flung the dearly ransomed flowerets there, When the dark wave closed o'er him, and no more Was seen young Rodolph on the Dimube's shore.

Aghast she stood; she saw the tranquil stream Pass o'er him-could it be a fleeting dream? Ah, no! the last fond words, "Forget me not!" Told it was all a sad reality.

With frantic grasp the dripping flowers she prest, Too dearly purchased, to her aching breast.

Alas! her tears, her sorrows now were vain, For him she loved she ne'er shall see again! Is this then a bridal, where, sad in her bower, The maid weeps alone at the nuptial hour ; Where hushed is the harp, and silent the lutcAh! why should their thrilling strains be mute? And where is young Rodolph? where stays the bridegroom?

Go, ask the dark waters, for there is his tomb.

Often at eve when maidens rove Beside the Danube's wave, 
They tell the tale of hapless love,

And show young Rodolph's grave ;

And eull the flowers from that sweet spot, Still calling them " Forget-me-not."

\section{FORGE'T-IIE-NOT.}

There is a little modest flower,

To friendship ever dear,

"Tis nourished in her humble bower,

And watered by her tear:

If hearts by fond affeetion tried, Should ehanee to slip away,

This little flower will gently chide

The heart that thus would stray.

All other flowers when once they fade Are left alone to die,

But this e'en when it is decayed,

Will live in memory's sigh.

\section{FORGET ME NOT.}

D. M. MOIR.

Summer was on the hills when last we parted.

Now the bright moon is shining

$O$ 'er the gay mountain and the stilly sea,

As, by the streamlet's willowy bend reelining

I pause, remembering thee. 
Yes! as we roamed, the sylvan earth seemed glowing

With many a beauty, unremarked before:

The soul was like a deep urn overflowing

With thoughts, a treasured store;

The very flowers seemed born but to exhale,

As breathed the west, their fragranee to the gale.

Methinks, even yet I feel thy timid fingers

With their bland pressure thrilling bliss to mine ;

Methinks, yet on my cleek thy breathing linger's

As-fondly leant to thine,

I told, how life all pleasureless wonld be,

Green palm-tree of life's desert! wanting thee.

Not yet, not yct had disappointment shrouded

Youth's summer ealm with storms of wintry strife :

The star of hope shone o'er our path unclouded.

And fancy colored life

With those elysian rainbow hues, which Truth Melts with his rod, when disenehanting youth.

Yet should it eheer me, that nor woe hath shattered The ties that link our hearts, nor hate nor wrath; And soon the day may dawn, when shall be scattered All shadows from our path,

For ah! with others wealth and mirth would be Less sweet, by far, than sorrow shared with thee!

Yes! rainly, foolishly the vulgar reekon, That happiness resides in outward shows:

Contentment from the lowliest eot may beekon True love to sweet repose :

For' genuine bliss can ne'cr be far apart, When soul meets soul, and heart responds to heart. 


\section{SONG OF THE FORGET-ME-NOT.}

How many bright flowers now around me are glancing, Each seeking its praise, or its beanty cnhancmg! 'The rose-buds are hanging like gems in the air, And the lily-bell waves in her frigrance there. Alas ! I can claim neither fortune nor power, Neither beauty nor fragrance are cast in my lot; But contented I cling to my lowly bower, And smile while I whisper-Forget-me-not!

\section{FORGET-ME-NOT. \\ NEW MONTHLY MAGAZNE.}

I CULLED each flow'ret for my fair, The wild thyme and the heather bell ; And round them twined a tendril rareShe said the posy pleased her well. But of the flowers that deck the field, Or grace the garden of the cot, Though others richer perfumes yield,

- The swcetest is forget-me-not.

We roamed the mead, we climbed the hill,

We rambled o'er the breckan brae;

The trees that crowned the mossy rill, They screened us from the glare of day. She said she loved the sylvan bower,

Was charmed with ev'ry rural spot; And when arrived the parting hour,

Her last words were "forget-me-not!" 


\title{
CAN YOU FORGET ME?
}

\author{
L. E. L.
}

Autums, while into languid Winter drooping, Gave its last blossoms, opening but to fall. Can you forget them?

Can you forget me ?' I am not relying

On plighted vows-alas! I know their worth. Man's faith to woman is a trifle, dying Upon the very breath that gave it birth.

\section{FORGET-ME-NOT.}

WITH SOME FORGET-ME NOTS.

JOHN INGRAM.

DEAR girl I send the spray of flowersAll withered now, once brightest blueTo call to mind those happy hours, 'Those happy hours I passed with you. Forget me not! though others win The glorious right to call thee "theirs!" Forget me not! that might have been The answer to my fervid prayers.

For I have had thy hand in mine, And once our ways in life seemed blended; And once I thought our loves might twine, But now, alas! that dream is ended. 
Forget me not! for I am lonely,

And stranded on Life's desert shore;

Forget me not !-I ask that only-

For now our paths may meet no more.

Could I but think you don't forget,

Though all my hopes of life should perish,

I'd pass them by without regret,

So that that thought I still might cherish.

Forget me not! 'tis all I ask,

And though thy hand may be another's,

I'll wear upon my face a mask

Of smiles to hide the grief it covers.

Let, then, these withered flowers recall

Each broken link of Memory's chain ;

And from the Past's dim haunted hall

Those happy hours bring back again.

Forget me not! mine only love-

Ah! would indeed that you were mine!

Forget me not! my long-lost dove,

In dreams my heart will beat next thine!

\section{HOLLYHOCK.}

(Ambition.)

"The fallen hollyhock."-Ebenezer ELLiot.

THE emblem of that crime by which Wolsey tells us

1 the angels fell is the tall and stately Hollyhock.

A few years ago it was often designated the "garden 
mallow." and, indeed, belongs to the mallow family. From the fact that it is known in France as Rose d'outre Mer, or "rose from beyond the sea," it has been surmised that it was first introdueed into Europe from Syria by the Crusaders.

"Queen Hollyhock, with butterflies for crowns."

\section{THE ROSE.}

(Love-Joy-Irosperity.)

THE Rose has been acknowledged by all antiquity I to be the queen of flowers, thongh her reign is somewhat disputed by the queen Lily. One is tempted to look on them both as sister sovereigns of the floral world. The Rose, the emblem of a material dominion "of the earth earthy;" the Lily, of a spiritnal empire of purity and lofty aspiration. But with all peoples the Rose has ever been the emblem of love, joy, and prosperity.

It is mentioned by the earliest writers of antiquity. Herodotus speaks of the double rose; in the song of Solonon the rose of Sharron is mentioned, and allusion is also made to the plantation of roses at Jericho. Isaiah uses the blossoming of the rose as a perfect emblem of joy and felicity.

The aneients regarded the Rose as the emblem of silenee, as well as of love and joy, and frequently represented Cupid offering one to Ifarpoerates, the God of Silence. As a further illustration of this symbolism, 
they suspended a rose over the table at feasts, intimating to the assembled guests that the eonversation was to be held saered, and was not to be repeated elsewhere. This latter aeeount is generally given as the eorreet derivation of the saying, "sub rosa," applied to eommunieations not to be repeated; but some writers say that the rose was onee dedieated to Harpoerates, and thus beeame the emblem of taciturnity, for which reason, it is arerred, it is frequently plaeed over the confessionals in Roman Catholic churches, indieating the seeresy whieh should attend whaterer may be there diselosed to the ears of the priest.

Roses were more highly prized by the Romans than any other flower ; they eonsidered them emblematie of joy, and, in eonformity with that idea, represented Comus, the God of pleasure, as a handsome young man, erowned with a garland of roses, the leaves of which glistened with dewdrops.

The Rose was, above all, the emblem of love :

"Most glorious rose,

You are the queenly belle. On you all eyes $\Lambda$ dmiring turn. Doubtless you might indite Romances from your own sweet historyThey're quite the fashion now, and crowd the page Of every periodical. Wilt tell

None of your heart adventures? Never mind!

We plainly read the Zephyr's stolen kiss

In your deep blush ; so where's the use to seal

Your lips so cunningly, when all the world

Calls you the flower of love g"-MrS. SigourNEY.

Anacreon thus writes of it:

"The rose, the flower of love,

Ningle with our quafling ; 
The rose, the lovely leaved,

Round our brows be weaved, Genially laughing.

" Oh, the rose, the first of flowers,

Darling of the early bowers,

E'en the gods for thee have places ;

Thee, too, Cytherea's boy

Weares about his locks for joy,

Dancing with the Graces.

The short life of this queenly flower causes it, when fading, to be deemed a suitable representative of fleeting beauty, and many are the "morals" that the poets have deduced from its brief existence; but there is another record to be made, and that is of its fragrance after death: the flush of beanty may be gone from its withered petals, but the scent of the rose will cling to it still; and so, even when life is over, we yet place, as Barry Cornwall says :

"First of all the rose, because its breath

Is rich beyond the rest; and when it dies, It doth bequeath a charm to sweeten death."

"The heart doth recognize thee, Alone, alone! the heart doth smell thee sweet, Doth view thee fair, doth judge thee most complete, Perceiving all those changes that disguise thee.

Yes, and the heart doth owe thee, More love, dead rose, than to any roses bold, Which Julia wears at dances, smiling cold !

Lie still upon this heart, which breaks below thee!" Mrs. Browning.

"Love is like a rose, And a month it may not see

Ere it withers where it grows."-BAILEx. 
Spenser has bequeathed us a rery felicitous stanza about the rose as an emblem of modesty and fragility :

"Ah ! see the virgin rose, how sweetly she Doth first peep forth with bashful modesty, That fairer seems the less ye see her may ! Lo! see soon after how, more bold and free, Her barèd bosom she doth broad display! Lo! see soon after how she fades and falls away !"

Sir Walter Scott tells us :

"The rose is fairest when 'tis budding new, And hope is brightest when it dawns from fears ; The rose is sweetest washed with morning dew, And love is loveliest when embalmed with tears."

\section{THE DYING ROSEBUD.}

MRS. OSGOOD.

Aн me! ah, woe is me!

That I should perish now,

With the dear sunlight just let in

Upon my balmy brow.

My leaves, instinct with glowing life, Were quivering to unclose;

My happy heart with love was rifeI was almost a rose.

Nerved by a hope, rich, warm, intense, Already I had risen

Above my cage's curving fence, My green and graceful prison. 
My pouting lips, by Zephyr pressed, Were just prepared to part, And whisper to the wooing wind The rapture of my heart.

In new-born fameies reveling, My mossy cell half-riven, Each thrilling leaflet seemed a wing To bear me into heaven.

How oft, while yet an infant flower, My erimson cheek I've laid Against the green bar's of my bower, Impatient of the shade;

And pressing up and peeping throngh

Its small but precious ristas, Sighed for the lovely light and dew That blessed my elder sisters.

I saw the sweet breeze rippling o'er Their leaves that lored the play, Though the light thief stole all the store of dewdrop gems away.

I thought how happy I should be Sneh diamond wreaths to wear, And frolic with a rose's glee With sunbeam, bird, and air.

All me! ah, woe is me ! that I,

Ere yet my leaves unclose, With all my wealth of sweets, must die Before I am a rose! 
ROSE.

\section{THE LESSON OF A ROSE.}

SPENSER.

Aн ! see whoso fayre thing doest faine to see, In springing flowre the image of thy day! $\mathrm{Ah}$ ! see the virgin rose, how sweetly shee Doth first peepe foorth with bashfull modestee, That fairer seems the lesse ye see her may! Lo! see soone after how, more bold and free, Her bared bosome she doth broad display; Lo! see soone after how she fades and falls away! So passeth, in the passing of a day Of mortal life, the leafe, the bud, the flowre; No more doth florish after first decay, That earst was sought to deck both bed and bowre Of many a lady, and many a paramowre! Gather therefore the rose whilest yet is prime; For soon comes age that will her pride defloure ; Gather the rose of love whilest yet is time, Whilest loving thou mayst loved be with equal crime.

\section{ZULEIKA'S ROSE.}

BYRON.

A SINGLE rose is shedding there Its lonely luster, meek and pale :

It looks as planted by despair-

So white, so faint-the slightest gale

Might whirl the leaves on high ;

And yet, though storms and blight assail, And hands more rude than wintry sky 
May wring it from its stem : in vainTo-morrow sees it bloom again!<smiles>[123I-]</smiles>

To it the livelong night there sings

A bird unseen, but not renote:

Invisible his aily wings,

But soft as harp that Houri strings

$\mathrm{His}$ long entrancing note.

THE ROSE.

The rose o'er crag or vale,

Sultana of the nightingale,

The maid for whom his melody,

His thousand songs are heard on high,

Blooms blushing to her lover's tale:

His queen, the garden queen, his rose,

Unbent by winds, unchilled by snows,

Far from the winters of the west,

By every breeze and season blest,

Returns the sweets by nature given

In softest incense back to heaven.

A SONG OF THE ROSE.

HEMANS.

Rose! what dost thou here, Pridal, royal rose?

How, 'midst grief and fear,

Canst thon thus disclose.

Thist fervid hue of lore, which to thy heart-leaf glows ? 
Rose! here too mueh arrayed

For triumphal hour's,

Look'st thou through the shade

Of these mortal bowers,

Not to disturb my soul, thou crowned one of all flowers?

As an eagle soaring

'Through a sunny sky,

As a elarion pouring

Notes of victory,

So dost thou kindle thoughts, for earthly life too high-

Thoughts of rapture, flushing

Youthful poet's cheek,

Thoughts of glory rushing

Forth in song to break,

But finding the spring-tide of rapid song too weak.

Yet, 0 festal rose !

I have seen thee lying

In thy bright repose

Pillowed witls the dying,

'Tlyy crimson by the life's quiek blood was flying.

Summer, hope, and love,

O'er that bed of pain,

Met in thee, yet wove

Too, too frail a ehain

In its embracing links the lovely to detain.

Smil'st thou, gorgeous flower?-

$\mathrm{Oh}$ ! within the spells

Of thy beanty's power

Something dimly dwells,

At rariance with a world of sorrows and farewells. 
All the soul forth fiowing In that rieh perfume, All the proud life glowing In that radiant bloom,

Have they mo plaee but bere, beneath th' o'ershadowing tomb?

Crown'st thou but the daughters

Of our tearful raee?-

Heaven's own purest waters

Well might bear the traee

Of thy eonsuminate form, melting tò softer graee.

Will that elime infold thee

With immortal air?

Shall we not behold thee

Bright and deathless there?

In spirit-luster elothed, transeendently more fair?

Yes! my faney sees thee

In that light diselose,

And its dream thus frees thee

From the mist of woes,

Darkening thine earthly bowers, 0 bridal, royal rose :

\section{THE ROSE.}

\section{ELTON'S SPECIMENS.}

Did Jove a queen of flowers deeree, The rose the queen of flowers should be. Of flowers the eye; of plants the gem ; The meadow's blush ; earth's diadem;

Glory of eolors, on the gaze

Lightening in its beauty's blaze; 
It breathes of love; it blooms the guest Of Venus' ever-fragrant breast; In gaudy pomp its petals spread ; Light foliage trembles round its head; With vermeil blossoms fresh and fair It laughs to the voluptuous air.

THE LAST ROSE OF SUMLIER.

BY T. MOORE.

'Tis the last Rose of summer

Left blooming alone, All her lovely companions

Are faded and gone ;

No flower of lier kindred,

No Rosebud is nigh, To reflect baek lier blushes

And give sigh for sigh.

I'll not leave thee, thou lone one, To pine on the stem;

Since the lovely are sleeping,

Go sleep thon with them.

Thus kindly I seatter

Thy leaves on the bed,

Where thy mates of the garden

Lie seentless and dead.

So soon may I follow

When friendships deeay,

And from love's shining eircle

The gems drop away; 
When true hearts lie wither'd, And fond ones are flown, Oh! who would inhabit This cold world alone?

\section{GATHER YOUR ROSES.}

ANTHOLOGIA OXONINESIS.

Live while you live, my boys!

Yet while the lamp doth shine;

Gather your roses

Ere they decline.

Man makes himself both cares and pains; He seeks for thorns, and thorns he gams :

But lets, alas! unheeded pass

The violet in his way.

Live while you live, my boys !

Yet while the lamp doth shine;

Gather your roses

Ere they decline.

ODE.

ANACREON (TRANSLATED BY MOORE.)

BuDs of roses, virgin flowers

Culled from Cupid's balmy bowers,

In the bowl of Bacchus steep,

Till with crimson drops they weep! 
Twine the rose, the garland twine,

Every leaf distilling wine ;

Drink and smile, and learn to think

'That we were born to smile and drink.

Rose! thou art the sweetest flower

That ever drank the amber shower ;

Rose! thou art the fondest child

Of dimpled spring, the wood-nymph wild!

Even the gods who walk the sky Are amorous of thy seented sigh. Cupid too, in Paphian shades, His hair with rosy fillet braids.

Then bring me shower's of roses, bring, And shed them round me while I sing.

THE MOSS ROSE.

FROM THE GERMAN OF KRUMMACHER.

The Angel of the flowers one day, Beneath a rose-tree sleeping lay ; That spirit to whose charge 'tis given To bathe young buds in dews of heaven ;Awakening from his hight repose, The Angel whispered to the Rose : "O fondest object of my care, Still fairest found, where all are fair ; For the sweet shade thou giv'st to me, Ask what thou wilt, 'tis granted thee!" Then said the Rose, with deepened glow, "On me another graee bestow ;" 
The spirit paused in silent thought,What graee was there that flower had not? 'Twas but a moment-o'er the Rose A veil of moss the Angel throws, And, robed in nature's simplest weed, Could there a flower that rose exeeed?

THE ROSE.

TRANSTATED FROM CAMOENS.

Just like lore is youder Rose :-

IIeavenly fragranee round it throws,

Yet tears its dewy leaves disclose,

And in the midst of briers it blows ;

Just like love.

Culled to bloom upon the breast, Since rongh thorns the stem invest, 'They must be gathered with the rest, And with it to the heart be prest;

$J$ ust like love.

And when rude hands the twin buds sever, They die, and they shall blossom never;

Yet the thorns be sharp as erer ;

Just like love.

THE LEGACY OF THE ROSES.

MISS L. E. LANDON.

OII ! plant them above me, the soft and bright, 'The touched with the sunset's crimson light, 
ROSE.

The warm with the earliest breath of Spring, 'The sweet with the sweep of the west wind's wing; Let the green bough and the red leaf ware,Plant the glad rose-tree upon my grave.

Why should the mournful willow weep, O'er the quiet rest of the dreamless sleep? Weep for life with its toil and care, Its crime to shun, and its sorrows to bear; Let tears, and the signs of tears be shed Over the living, not over the dead.

Plant not the cypress, nor yet the yew, 'Too heavy their shadow, too gloomy their hue, For one who is sleeping in faith and love, With a hope that is treasured in heaven above; In a holy trust are my ashes laid, Cast ye no darkness, throw ye no shade.

Plant the green sod with the erimson rose, Let my friends rejoice o'er my calm repose ; Let my memory be like the odors shed, My hope like the promise of early red; Let strangers share in their breath and bloom, Plant ye the bright roses over my tomb.

GATHER YE ROSE-BUDS.

HERRICK.

Gather ye rose-buds while ye may, old time is still a-flying; And this same flower that smiles to-day, To-morrow will be dying. 
'The glorious lamp of hearen, the sun,

The higher he's a-getting;

'I'lle sooner will his raee be run,

The nearer lie's a-setting.

That age is best, that is the first,

When youth and blood are warmer;

But being spent, the worse, and worst

'I'imes still sueceed the former.

Then be not eoy, but use your time;

And while ye may, go marry;

For having lost but once your prime,

You may forever tarry.

\section{SENSITIVE PLANT.}

(Bashful Love.)

THIS delieate emblem of bashfulness is a member tall tree.

The old pastoral poet, W. Browne, alludes to its peeuliarities thus :

" Look how the feeling-plant, which learned swains

Relate to grow on the East Indian plains,

Shrinks up his dainty leaves if any sand

You throw thereon, or touch it with your hand."

Matthew Prior alludes to the diversity of opinion as to what eauses this phenomenon : 
"Whence does it happen that the plant, which well We name the 'sensitive,' should move and feel? Whence know her leaves to answer her command, And with quick horror fly the neighboring hand?"

There is one most remarkable member of this extraordinary family, known as the "friendly-tree," which droops its branches whenever any person approaches it, seeming as if it saluted those who sought retreat beneath its sheltering boughs. Moore calls it

"That courteous tree, Which bows to all who seck its canopy."

\section{THE MIMOSA.}

DARWIN.

WEAK, with nice sense, the chaste mimosa stands ;

From each rude touch withdraws her timid hands. Oft, as light clouds pass o'er the Summer's glade, Alarmed, she trembles at the moving shade, And feels alive through all her tender form The whispered murmurs of the gathering storm;

Shuts her sweet eyelids to approaching night, And hails with freshened charms the rosy light. 


\section{EVENING PRIMROSE.}

\section{(Silent Love.)}

"Love us as emblems, night's dewy flowers."-Mrs. Memans.

THE evening primrose is dedieated by Roman CathL olies to St. Elizabeth, Queen of Portugal. It has not elieited so many poetieal addresses as its sister of the day, yet has not been quite overlooked. Keats mused thus on

"A tuft of evening primroses, 0 'er which the mind may hover till it dozes ; O'er whieh it well might take a pleasant sleep, But that 'tis ever' startled by the leap of buds into ripe flowers."

\section{THE EVENING PRAIROSE.}

\section{LANGIIORNE.}

THere are that love the shades of life, And shun the splendid walks of fame;

There are that hold it rueful strife 'To risk $\Lambda$ mbition's losing game;

That far from envy's lurid eye

The fairest fruits of genius rear,

Content to see them bloom and die

In friendship's small but kindly sphere. 
Than vainer flowers, though sweeter far, The Evening Primrose sluns the day; Blooms only to the western star, And love its solitary ray.

In Eden's vale an aged hind At the dum twilight's elosing hour, On his time-smoothed staff reelined, With wonder viewed the openıng flower.

"Ill-fated flower, at eve to blow," (In pity's simple thought he eries,) "Thy bosom must not feel the glow Of splendid suns, or smiling skies.

"Nor thee the vagrants of the field, The hamlet's little train behold;

Their eyes to sweet oppression yield, When thine the falling shades unfold.

"Nor thee the hasty shepherd heeds, When love has filled his heart with cares: For flowers he rifles all the meads;

For waking flowers-but thine forbears.

"Ah ! waste no more that beauteous bloom, On night's ehill shade that fragrant breath;

Let smlling suns those gems illume!

Fair flower! to live unseen is death !"

Soft as the voice of vernal gales

That o'er the bending meadows blow, Or streams that steal through even vales, And murmur that they move so slow. 
Deep in her unfrequented bower,

Sweet Philomela poured her strain ;

The bird of eve approved her flower,

And answered thus the anxious swain :-

\section{"Live unseen!}

By moonlight shades, in valleys green,

Lovely flower, we'll live unseen.

Of our pleasures deem not lightly,

Laughing day may look more sprightly;

But I love the modest mien,

Still I love the modest mien

Of gentle evening fair, and her star-trained queen.

"Didst thou, shepherd, never find

Pleasure is of pensive kind?

Has thy cottage never known

That she loves to dwell alone?

Dost thou not at evening hour

Feel some soft and secret power

Gliding o'er thy yielding mind,

Leave sweet serenity behind,

While, all disarmed, the cares of day

Steal through the falling gloom away;

Love to think thy lot was laid

In this undistinguished shade;

Far from the world's infectious view

Thy little virtnes safely blew?

Go, and in day's more dangerous hour,

Guard thy emblematic flower." 


\section{THE HELIOTROPE.}

\section{(Devoted Attachment.)}

7 HE Heliotrope divides with the Sunflower the 1 fable of representing Clytie, who died of love for the sun, the course of which its flowers are supposed to follow.

This is Ovid's* relation of her fate :

"She with distracted passion pines away;

Detesteth company ; all night, all diay

Disrobèd, with her ruffled hair unbound, And wet with humor, sits upon the ground :

For nine long days all sustenance forbcars ;

Her hunger cloyed with dew, her thirst with tears :

Nor rose ; but rivets on the god her eyes, And ever turns her face to him that flies. At length to earth her stupid body eleaves ; Her wall complexion turns to bloodless leaves.

Yet streaked with red, her perished limbs beget

A flower resembling the pale violet, Which with the sun, though rooted fast, doth move, And being changèd, changeth not her love."

\section{THE HELIOTROPE.}

ANON.

THERE is a flower whose modest eye

Is turned with looks of light and love, Who breathes her sweetest, softest sigh, Whene'er the sun is bright above. 
Let elouds obscure, or darkness veil, Her fond idolatry is fled; Her sighs no more their sweets exhale, The loving eye is cold and dead.

Canst thou not trace a moral here,

False flatterer of the prosperous hour?

Let but an adverse cloud appear, And thou art faithless as the flower.

\section{HELIOTROPE.}

Stre, enamored of the sun, At his departure hangs her head and weeps, And shrouds her sweetness up, and keeps

Sad rigils like a cloistered nun, 'Till his reviving ray appears, Waking her beauty as he dries her tears.

\section{SWEETBRIAR.}

\section{(I Wound to Meal.)}

TWE cannot undertake to explain why this singular meaning has been given to Sweetbriar.

It is called by the older poets "Eglantine"-a name sometimes erroneously given to the Honeysuekle. The strong perfume of Sweetbriar in a bouquet kills the other flowers which form it. 
TO THE SWEETBRIAR.

BRAINARD.

OUR sweet autumnal western-scented wind Robs of its odors none so sweet a flower, In all the blooming waste it left behind, As that sweetbriar yields it ; and the shower Wets not a rose that buds in beanty's bower One half so lovely; yet it grows along The poor girl's pathway ; by the poor man's door. Such are the simple folks it dwells among; And humble as the bud, so humble be the song.

I love it, for it takes its untouched stand Not in the vase that seulptors decorate;

Its sweetness all is of my native land; And e'en its fragrant leaf has not its mate Among the perfumes which the rich and great Bring from the odors of the spicy East.

You love your flowers and plants, and will you hate The little four-leaved rose that I love best, That freshest will awake, and sweetest go to rest? 


\section{LADY FÉRN.}

(Fascination.)

\section{LADY FERN. \\ CALDER CAMPBELL.}

TF you would see the lady fern

I In all her graecful power,

Go look for her where woodlarks learn

Love-songs in a summer bower ;

Where not far off, nor yet close by,

A merry stream trips on,

Just near enow for an old man's eye

To watch the waters run,

And leap o'er many a cluster white

Of erowfoots o'er them spread;

While hart's tongues quiet with a green more bright

Where the braekens make their bed.

Ferns all-and lovely all--yet each

Yielding in eharms to her

Whose natural graees Art might teach

High lessons to confer.

Go look for the pimpernel by day,

For Selene's flowers by night,

For the first loves to bask in the sunny ray,

And the last woos the moon's soft light:

But day or night the lady fern

May eatch and eharm your eye,

When the sun to gold her emerald turns,

Or the moon lends her silver dye. 
But seek her not in early May,

For a Sibyl then she looks,

With wrinkled fronds that seem to say,

"Shut up my wizard books!"

Then seareh for her in the summer woods,

Where rills keep moist the ground,

Where foxgloves from their spotted hoods

Shake pilfering insects round;

Where up and elambering all about,

The traveller's joy flings forth

Its snowy awns, that in and out

Like feathers strew the earth.

Fair are the tufts of meadow sweet

That haply blossom nigh,

Fair are the whorls of violet

Prunella shows hard by ;

But not by burn, in wood, or dale,

Grows anything so fair

As the plumy crest of emerald pale

That waves in the wind, or soughs in the gale,

Of the Lady fern, when the sunbeams turn

To gold her delicate hair.

WALTER SCOTT'.

WHERE the eopse-wood is the greenest,

Where the fountain glistens sheenest,

Where the morning dew lies longest,

There the lady fern grows strongest. 


\section{MYRTLE.}

\section{(Love.)}

THE Myrtle, like the rose, is generally considered 1 symbolic of love, and by the Greeks and Romans was consecrated to Venus, round whose temples they planted groves of it; and, when the votaries of this goddess sacrificed to her, they, like her attendant Graces, wore myrtle cliaplets.

The Myrtle is supposed to derive its name from $\mathbf{M y r}$ sine, an Athenian maiden, and favorite of Minerva, said to have been metamorphosed into the myrtle; at any rate, it owes its origin to a Greek word signlfying perfume.

Among the ancient writers who speak of its symbolism is Phny : he records that the Romans and Sabines, when they were reconciled, laid down their weapons under a myrtle-tree, and purified themselves with its boughs. When Harmodius and Aristogiton set forth to free their country from a tyrant, their swords were wreathed with myrtle.

A MYRTLE.

KEATS.

A Mrrtle, fairer than

E'er grew in Paphos, from the bitter weeds

Lifts its sweet head into the air, and feeds 
A silent spaee with ever-sprouting green. All tenderest birds there find a pleasant screen, Crcep through the shade with noisy fluttering, Nibble the little cupped flowers, and sing.

THELR.GROVES O' SWEET MYRTLE.

BURNS.

'THerr groves o' sweet myrtlc let foreign lands reekon, When briglit beaming summers exalt the perfume; Far dearer to me yon lone glen or green bracken, Wi' the burn stealing under the lang yellow broom.

Far dearer to me all yon humble brown bowers,

Where the bluebell and gowan lurk lowly unseen; For there lightly tripping amang the wild flowers,

A-listening the linnet, aft wanders my Jean.

\section{JASMINE.}

\section{(Amiability.)}

\footnotetext{
VANY significations are attached to this exquisitely 1 scented flower, but the most reliable works adopt it as the representative of amabilnty.
} 
THE JASMINE.

COWPER.

THE jasmine throwing wide her elegant sweets, 'The deep dark green of whose unvarnished leaf Makes more conspicuous and illumines more The bright profusion of her scattered stars.

\section{TO A JASMINE TREE}

GROWING IN THE COURT OF NATORTI CASTLE.

LORD MORPETH.

Mr slight and slender jasmine-tree,

That bloomest on my Border-tower,

Thou art more dearly loved by me

Than all the wealth of fairy bower.

I ask not, while I near thee dwell;

Arabia's spice or Syria's rose ;

Thy bright festoons more freshly smell, Thy virgin white more freshly glows.

My wild and winsome jasmine-tree, That climbest up the dark-gray wall,

Thy tiny flowerets seem in glee,

Like silver spray-drops down to fall : Say, did they from their leaves thus peep,

When mailed moss-troopers rode the hill? When helmed wardens paced the keep, And bugles blew for Belted Will? 
My free and feathery jasmine-tree, Within the fragranee of thy breath,

- Yon dungeon grated to its key,

And the clsained captive pined for death.

On Border fray, on feudal crime,

I dream not while I gaze on thee;

The ehieftains of that stern old time

Could ne'er have loved a jasmine-tree.

\section{JASMINE.}

MOORE.

THE image of Love that nightly flies

To visit the bashful maid,

Steals from the jasmine flower, that sighs

Its sonl like her in the shade.

The dream of a future happier hour

'That alights on misery's brow,

Springs out of the silvery almond flower

That blooms on a leafless bough.

NIGHT SCENTING JASMINE.

MOORE.

MANy a perfume breathed

From plants that wake when others sleep;

From timid jasmine-buds that keep

Their odor to themselves all day,

But when the sunlight dies away

Let the delicious seeret out

To every breeze that roams about. 


\title{
PERFUME OF JASMINE.
}

\author{
CHURCHILL.
}

The jasmine, with whieh the queen of flowers, To charm her god, adorns his farorite bowers; Whieh brides, by the plain hand of neatness drest,Unenvied rival ! - wear upon the breast; Sweet as the ineense of the morn, and chaste As the pure zone which cireles Dian's waist.

\section{ON THE INDIAN-JASMINE FLOWER.}

RYAN.

How lovelily the jasmine flower

Blooms far from man's observing eyes: And having lived its little hour,

There withers, 一there sequestered dies !

Though faded, yet 'tis not forgot;

A rieh perfume time eannot sever

Linger's in that unfriended spot,

And deeks the jasmine's grave forever.

Thus, thus should man who seeks to soar

On learning's wings to fame's bright sky,

Far from his fellows seek that lore,

Unheeded live, sequestered die.

Thus, like the jasmine, when he's fled,

Fame's rich perfume will ever keep,

Lingering around the faded dead,

As saints that watch some infant's sleep. 


\section{THE JASMINE.}

\section{MOORE.}

'Twas midnight-through the lattiee wreathed With woodbine, many a perfume breathed From plants that wake when others sleep; From timid Jasmine buds that keep Their odor to themselves all day; But when the sunlight dies away, Let the delieious seeret ont To every breeze that roams about.

\section{TO THE JESSIIIINE.}

MISS JANE TAYLOR.

Sweet jessamine, long may tliy elegant flower Breathe fragranee and solace for me:

And long thy green sprigs overshadow the bower Devoted to friendship and thee.

The eye that was dazzled where lilies and roses Their brilliant assemblage displayed, With grateful delight on thy verdure reposes, A tranquil and delicate shade.

But ah! what dejection that foliage expresses Which pensively droops on her breast ! The dew of the evening has laden her tresses, And stands like a tear on her erest. 
I'll watch by thy side through the gloom of the night Impatient till morning appears :

No charm can awaken this heart to delight, My jasmine, while thou art in tears.

But soon will the shadows of night be withdrawn,

Which ever in mercy are given;

And thou shalt be cheered by the light of the morn,

And fanned by the breezes of heaven.

And still may thy tranquil and delicate shade

Yield fragrance and solace to me;

For though all the flowers in my garden should fade, My heart will repose upon thee.

\section{POPPY.}

\section{(Consolation-Oblivion.)}

THE Poppy, Greek mythologists tell us, was created 1 by Ceres whilst in search of her daughter Proserpine, as a soother of her grief. The pastoral poet, William Browne, in his quaint phraseology, says :

"Sleep-bringing poppy, by the plowman late, Not without cause, to Ceres consecrate : For being round and full at his half-birth, It signified the perfect orb of earth ; And by his inequalities when blowne, The earth's low vales and higher hills were showne; By multitude of grains it held within, of men and beasts the number noted bin. 
Or since her daughter that she loved so well, By him that in the infermal shades does dwell, * $\quad * \quad * \quad * \quad *$

Fairest Proserpina was rapt away, And she in plaints the night, in tears the day, Had long time spent; when no high power could give her Any redresse, the poppy did relieve her : For, eating of the seeds, they sleep procured, And so beguiled those griefs she long endured.

\section{THROUGH THE FIELDS.}

\section{WILLIAM SAWTER.}

Pleasant beneath this burning sky of June, To trcad the field-paths by these hedges gay, With shining golse and rosy-blossomed May, To linger here, where in full blaze of noon, Under the quivering branches of the trees, The air is cool and fragrant, and the light Comes greenly tempered to the aching sight;

Or to pass hence, and plunging to the knees In a green meadow, wade to the full sea Of flowering grasses, foaming as we go With clustering daisies. Nought morc sweet may bc, The while the skylight soars and sings, and lo! The cuckoo. lone Narcissus of the woods, Of his own name enamored, still that name intrudes. 


\section{ORANGE-BLOSSOM.}

(Your purity equals your loveliness.)

RANGE-BLOSSOM is generally deemed typical of chastity. 'The practice of brides wearing a wreath of it on their wedding-day, though still retained in some countries, is not so fashionable here as formerly.

In his "Ode to Memory," Tennyson alludes to the custom of using these blossoms at nuptials thus :

"Like a bird of old

In triumph led,

With music and sweet, showers

Of festal flowers,

Unto the dwelling she must sway."

THE ORANGE-BLOSSOM.

Just then, beneath some orange-trees,

Whose fruit and blossoms in the breeze

Were wantoning together, free,

Like age at play with infancy.

THE ORANGE-TREE.

SPENSER.

NExT theremnto did grow a goodly tree,

With branches broad dispread and body great, Clothèd with leaves, that none the wood might see, And laden all with fruit, as thick as thick might be. 
The fruit were golden apples glistering bright, 'That goodly was their glory to behold; On earth no better grew, nor living wight E'er better saw, but they from henee* were sold, For those which Hercules, with conquest bold, Got from great Atlas' daughters, hence began, And planted there, did bring forth fruit of gold, And those with which th' Eubœan young man wan [won]

Swift Atalanta, when, through craft, he her outran.

Here also sprang that goodly golden fruit

With which Acontius got his lover true, Whom he had long time sought with fruitless suit;

Here eke that famous golden apple grew, 'The which among the gods false Atè threw, For which the Idæan ladies disagreed, Till partial Paris deemed it Venus' due, And had [of her] fair Helen for his meed, 'That many noble Greeks and Trojans made to bleed.

\section{TO TIIE HUMMING BIRD.}

CIIARLOTTE SMITH.

There, lovely bee-bird! mayst thou rove Through spicy vale and citron grove, And woo and win thy fluttering love With plume so bright;

* The garden of Proserpina. 
There rapid fly, more heard than seen, 'Mid orange-boughs of polished green, With glowing fruit, and flowers between Of purest white.

THE ORANGE-BOUGH.

MRS. IIEMANS.

$\mathrm{OH}$ ! bring me one swect orange-bough, To fan my cheek, to cool my brow ; One bough, with pearly blossoms dressed, And bind it, mother ! on my breast !

Go seek the grove along the shore, Whose odors I must breathe no more, The grove where every scented tree Thrills to the deep voice of the sea.

Oh ! Love's fond sighs, and fervent prayer, And wild farewell, are lingering there, Each leaf's light whisper hath a tone, My faint heart, even in death, would own.

Then bear me thence one bough, to shed Life's parting sweetness round my head, And bind it, mother! on my breast When I am laid in lonely rest. 


\section{ANEMONE.}

\section{(Withered Hopes-Forsaken.)}

7 HIS flower derives its name from anemos, the Greek 1 word for wind, from thenee eame our poetieal appellation of "the wind-flower." The aneients tell us that the Anemone was formerly a nymph beloved by Zephyr, and that Flora, jealous of her beauty, banished her from her Court, and finally transformed her into the flower that now bears her name. The more common myth is, that the anemone sprang from the blood of Adonis, combined with the tears which Venus shed over his body. The Greek poet Bion, in his "Lament for Adonis," says :

"That wretched queen, Adonis bewailing, For every drop of blood lets fall a tear ; Two blooming flowers the mingled streams disclose ; Anemone the tears ; the blood, a rose."

\section{TO THE ANEMONE.}

MISS PRATT.

FLowers of the wild wood! your home is there, 'Mid all that is fragrant, all that is fair ;

Where the wood-mouse makes his home in the earth ;

Where gnat and butterfly have their birth ;

Where leaves are dancing over each flower,

Fanning it well in the noontide hour,

And the breath of the wind is murmuring low,

As branches are bending to and fro. 
Sweet are the memories that ye bring

Of the pleasant leafy woods of spring;

Of the wild bee, so gladly humming,

Joyous that earth's young flowers are coming ;

Of the nightingale and merry thrush,

Cheerfully singing from every bush ;

And the cuckoo's note, when the air is still, Ileard far away on the distant lill.

* $* \begin{array}{llllll}* & * & * & * & *\end{array}$

Pure are the sights and sounds of the wild

Ye can bring to the heart of Nature's child;

Plain and beautiful is the story

That ye tell of your Maker's glory ;

Useful the lesson that ye bear,

That fragile is all, however fair ;

While ye teach that time is on his wing, As ye open the blossoms of every spring.

THE RED ANEIIONE.

TENNYSON.

Growths of jasmine turned

Their humid arms, festooning tree and tree, And at the root throngh lush green grasses burned The red anemone. 


\section{ASPHODEL.}

(I aill be fuithful unto Death.)

A NCIENTLY dedicated to the memory of deA parted souls, the asphodel is still very common in Greece; it was planted around the tombs of the deceased; and it was believed that beyond the fatal river Acheron, the shades wandered in a rast field of asphodels, and drank forgetfulness from Lethe's waters of oblivion. The flowers of the asphodel produce grains with which it was thought that the dead were nourisher. Orpheus, in Pope's "Ode for St. Cecilia's Day," eonjures the infernal deities:

"By the streams that ever flow,

By the fragrant winds that blow

O'er the Elysian flowers:

By those haply souls who dwell

In yellow meads of asphodel

Or amaranthine bowers."

We have as old an authority as Homer for stating that, after having erossed the Styx, the shades passed over a long plain of asphodels. Hence the meaning attached to the flower.

\section{HONEYSUCKLE.}

(Generous, devoted Affection.)

THIS exquisite flower has something so homelike $\mathcal{L}$ and English about it that we marrel it has not met with more poetical appreciation. All the glories 
of East and West eannot rival its blossoms in our estimation. Often in Eastern lands have we longed for the honeysuckle lanes of England. It grows (for the benefit of the wayfarer) in the hedgerow : it clasps the porch and thatch of the poor man's cottage: it wafts soothing perfume to the lover.

\section{THE HONEYSUCKLE.}

THE COUNTESS OF BIESSINGTON.

Sex the Honeysuckle twine

Round this casement :-'tis a shrine

Where the heart doth incense give,

And the poor affections live

In the mother's gentle breast

By her smiling infant pressed.

Blessed shrine ! dear, blissful home!

Source whence happiness doth come!

Round by the cheerful hearth we meet

All things beauteous-all things sweet-

Every solace of man's life,

Mother-daughter-sister-wife ?

England, Isle of free and brave,

Circled by the Atlantic ware!

Though we seck the fairest land

That the south wind ever fanned,

Yet we eannot hope to see

Homes so holy as in thee. 
As the tortoise turns its head

Towards its native oecan-bed,

Howsoerer far it be

From its own beloved sea,

Thus, dear Albion, erermore

Do we turn, to seek thy shore!

\section{FRAGMENT.}

SIR WALTER SCOTT.

AND well the lonely infant knew

Recesses where the wallflower grew,

And honeysuekle loved to erawl

Up the low erag and ruined wall.

I deemed sueh nooks the sweetest shade

The sim in all his round surveyed,

And still I thought that shattered tower

The mightiest work of human power.

\section{WOODBINE.}

SHAKSPEARE.

I kNow a bank whereon the wild thyme blows.

Where oxlips and the uodding violet grows ;

Quite over-eanopied with lush woodbine,

With sweet musk-roses, and with eglantine :

There sleeps Titania, some time of the night, Lulled in these flowers with dances and delight: And there the snake throws her enameled skin, Weed wide enough to wrap a fairy in. 


\section{THE QUESTION.}

\section{SHELLEY.}

I DREAMED that, as I wandered by the way, Bare winter suddenly was changed to spring, And gentle odors led my steps astray,

Vixed with a sound of waters murmuring Along a shelving bank of turf, which lay

Under a copse, and hardly dared to filing Its green arms round the bosom of the stream, But kissed it and then fled, as thou mightest in dream.

There grew pied wind-flowers and violets,

Daisies, those pearled Areturi of the earth, The constellated flower that never sets;

Faint oxlips ; tender bluebeils, at whose birth The sod searce heaved; and that tall flower that wets Its mother's faee with heaven-eolleeted tears, When the low wind, its playmate's voiee, it hears.

And in the warm hedge grew lush eglantine,

Green eowbind and the moonlight-eolored May, And cherry blossoms, and white cups, whose wine

Was the bright dew yet drained not by the day; And wild roses, and ivy serpentine,

With its dark buds and leaves, wandering astray, And flowers azure, blaek, and streaked with gold; Fairer than any wakened eyes behold.

And nearer to the river's trembling edge

There grew broad flag-flowers, purple prankt with white,

And starry river burs among the sedge,

And floating water-lilies, broad and bright, 
Which lit the oak that overhung the hedge

With moonlight beams of their own watery light;

And bulrushes and reeds of sueh deep green

As soothed the dazzled eye with sober sheen.

Methought that of these visionary flowers

I made a nosegay, bound in such a way

That the same hues which in their natural bowers

Were mingled or opposed, the like array

Kept these imprisoned ehildren of the hours

Within my hand, - and then, elate and gay,

I hastened to the spot whenee I had eome,

That I might there present it!-oh! to whom?

FROM THE "RAPE OF PROSERPINE."

BARRY CORNWALL.

Here this rose

(This one half-blown) shall be my Maia's portion

For that like it her blush is beautiful;

And this deep violet, almost as blue

As Pallas' eye, or thine Lycinnia,

I'll give to thee; for like thyself it wears

Its swcetness, ne'er obtruding. For this lily,

Where can it hang but at Cyane's breast?

And yet 'twill wither on so white a bed,

If flowers have sense, for envy :-It shall lie

Amongst thy raven tresses, Cytheris,

Like one star on the bosom of the night.

The eowslip, and the yellow primrose, they

Are gone, my sad Leontia, to their griuves,

And April hath wept o'er them, and the voice 
Of March hath sung, even before their deaths, The dirge of those young ehildren of the year. But here is heart's-ease for your woes. And now, The honeysuekle flower I give to thee, And love it for my sake, my own Cyane: It hangs upon the stem it loves, as thou Hast clung to me, through every joy and sorrow ; It flourishes with its guardian's growth, as thou dost; And if the woodman's axe should drop the tree, The woodbine too must perish.

\section{WREATHS.}

Weate thee a wreath of woodbine, child, 'Twill suit thy infant brow;

It runs up free in the woodlands wild, As tender and as frail as thou.

He bound his brow with a woodbine wreath, And smiled his playful eye, And he lightly skipped o'er the blossomed heath, In his young heart's eestasy.

I saw him not till his manly brow Was clouded with thought and care, And the smile of youth, and its beauty, now No longer wantoned there.

Go, twine thee a crown of the ivy tree, And gladden thy loaded breast : Bright days may yet shine out for thee, And thy bosom again know rest. 
Long years rolled on,-_and I saw again

His form in hoary age ;

His forehead was deeply furrowed then,

In life's last feeble stage.

$O$ be thy crown, old man, I said, of the yew and the cypress made, A garland meet for thy silvered head Ere it low in the tomb be laid.

And such is life, and such is man

In his fleeting course below :

His little day, that in joy began, Must proceed and end in woe;

But another day shall weave for him

A garland that will not die,

And his cup of bliss shall o'erflow its brim ;-

$\mathrm{He}$ shall live eternally.

HONEYSUCKLES.

KEATS.

DEW-SWEET eglantine, And honeysuckles full of clear bee-wine. 


\title{
CELANDINE;
}

\author{
OR, \\ SWALLOW HERB.
}

(Deceptive Hopes.)

7 IIIS emblem of deceptive hopes derives its botanical 1 name from a Greek word signifying a swallow, because, say some, of its eoming and going with that bird ; but aecording to Gerarde, it was so ealled from an opinion which prevailed among the eountry people, that the old swallows used it to restore sight to their young when their eyes were out.

TO THE SHALL CELANDINE.

(COMMON PILE WORT.)

WORDSWORTH.

Pansies, lilies, kingeups, daisies,

Let them live upon their praises;

Long as there's a sun that sets,

Primroses will have their glory;

Long as there are violets,

They will have a plaee in story;

There's a flower that shall be mine,

'Tis the little Celandine.

Eyes of some men trarel far

For the finding of a star; 
Up and down the heavens they go, Men that keep a mighty rout; I'm as great as they, I trow, Sinee the lay I found thee out, Little flower-I'll make is stir Like a sage istronomer.

Modest, yet withal an elf, Bold, and lavish of thyself;

Since we needs must first have met I have seen thee, high and low, Thirty years or more and yet, 'Twas a face I did not know ; Thou hast now, go where I may, Fifty greetings in a day.

Ere a leaf is on a bush, In the time before the thrush Has a thought about her nest, Thou wilt ecme with half a eall, Spreading sut thy glossy breast Like a careless Prodigal ; Telling tales abont the sun When we've little warmth or none.

Poets, vain men in their mood, Travel with the multitude:

Never heed them : I aver

That they all are wanton wooers;

But the thrifty cottager,

Who stirs little out of doors, Joys to spy thee near her home : Spring is eoming; thou art eome; 
Comfort have thou of thy merit, Kindly unassuming spirit!

Careless of thy neighborhood, Thou dost show thy pleasant face On the moor, and in the wood, In the lane; there's not a place Howsoever mean it be, But'tis good enough for thee.

Ill befall the yellow flowers, Children of the flaring hours! Buttercups that will be seen, Whether we will see or no;

Others, too, of lofty mien, They have done as worldlings do, Taken praise that should be thine, Little, humble Celandine.

Prophet of delight and mirth, Ill reputed upon earth ;

Iferald of a mighty band, Of a joyous train ensuing, Serving at my heart's command, Tasks that are no tasks renewing, I will sing, as doth behove, Hymns in praise of what I love ! 


\section{WEEPING WILLOW.}

\section{(Mourning.)}

THIS tree has ever been regarded as the symbol of 1 sorrow, and most appropriately, for not only do its pensive-looking branches droop mournfully towards the ground, but even very frequently little drops of water are to be seen standing, like tear's, upon the pendent leares. In its native East it is often planted orer graves, and with its sorrowful, afflieted look, forms a most appropriate guardian of the departed ones' rest.

"The famous and admired weeping willow," says Martyn, "planted by Pope, whieh has sinee been felled to the ground, eame from Spain, inelosing a present for Lady Suffolk. Pope was present when the eovering was taken off; he observed that the piees of stick appeared as if they had some vegetation, and added, 'Perhaps they may produce something we have not in England.' Under this idea, he planted it in his garden, and it produeed the willow-tree that has given birth to so many others."

\section{THE WILLOW.}

BYRON.

We sat down and wept by the waters Of Babel, and thought of the day, When our foe, in the hue of his slaughters, Made Salem's high places his prey; And ye, $\mathrm{O}$ her desolate daughters !

Were scattered all weeping away. 
While sadly we gazed on the river,

Which rolled on in freedom below, He demanded the song; but, oh, never That triumph the stranger shall know! May this right hand be withered forever Ere it string our high harp for the foe!

On the willows that harp is suspended, O Salem! Its sound should be free : And the hour when thy glories were ended But left me that token of thee ; And ne'er shall its soft note be blended With the voice of the spoiler by me.

\section{WEARING THE WILLOW.}

PERCY'S RELIQUES.

Willy-How now, shepherde, what meanes that? Why that willowe in thy hat?

Why thy scarffes of red and yellowe Turned to branches of green willowe?

Cuddy-They are changed, and so am I; Sorrowes live, but pleasures die: Phillis hath forsaken mee, Which makes me weare the willowe-tr

Willy-Shepherde, be advised by mee, Cast off grief and willowe-tree; For thy grief brings her content: She is pleased if thou lament. 
Cuddy-Herdsman, I'll be ruled by thee,'There lices grief and willowe-tree;

Henceforth I will do as they, And love a new love every day.

\section{THE WILLOW.}

\section{SIAKSPEARE.}

Mr mother had a maid called Barbara :

She was in love; but he she loved proved mad, And did forsake her. She had a song of "Willow." An old thing 'twas, but it expressed her fortune, And she died singing it.

\section{THE WILLOW.}

\section{SHAKSPEARE.}

THERe is a willow grows aslant the brook, That shows his hoar leaves in the glassy stream; There with fantastic garlands did she* eome, Of crow-flowers, nettles, daisies, and long purples, That liberal shepherds give a grosser name, But our eold maids do dead men's fingers eall them; 'There on the pendent boughs her coronet weeds Clambering to hang, an envious sliver broke; When down her weedy trophies and herself Fell in the weeping brook. 
TO A WILLOW-TREE.

HEIRKICK.

ThOu art to all lost love the best, The only true plant found;

Wherewith young men and maids distrest, And left of love, are erowned.

When onee the lover's rose is dead, Or laid aside forlorn, Then willow garlands 'bout the head, Bedewed with tears, are worn.

When with neglect the lover's bane, Poor maids rewarded be ; For their love lost, their on]y gain Is but a wreath from thee.

And underneath thy cooling shade,

When weary of the light, The love-spent youth and love-sick maid

Come to weep out the night.

\section{THE GARLAND.}

MOORE.

A WILLow garland thou didst send, Perfumed, last day, to me ; Which did but only this portend:

I was forsook by thee. 
Since so it is, I'll tell thee what:

To-morrow thou shalt see

Me wear the willow; after that

To die upon the tree.

As beasts unto the altar go

With garlands dressed, so I

Will with my willow wreath also

Come forth and sweetly die.

\section{SONNET.}

GARCILASSO.

For Daphne's laurel Phobus gave his voice : The towering popiar charmed stern Hereules; The myrtle sweet, whose gifted flowers rejoice Young hearts in love, did most warm Venus please; The little green willow is my Fledri's choice:

She gathers it amidst a thousand trees. Thus laurel, poplar, and sweet myrtle now, Where'er it grows, shall to the willow bow.

\section{THE DROOPING WILLOW.}

\section{E. L.}

GREeN willow ! over whom the perilous blast Is sweeping roughly, thou dost seem to me The patient emblem of humility, Waiting in meekness till the storm be passed, Assured an hour of peace will eome at last ; That there will be for thee a ealm bright day When the dark cionds are gathered far away. 
How canst thou ever sorrow's emblems be? Rather I deem thy slight and fragile form, In mild endurance bending gracefully, Is like the wounded heart, which 'mid the storm Looks for the promised time which is to be, In pious confidenee. Oh ! thou shouldst wave Thy branches o'er the lowly martyr's grave.

\section{SUNFLOWER.}

\section{(Fidelity.)}

PIIE classic legend of Clytie has been attaehed to the 1 sunflower. 'That nymph had been beloved by Helios, but it was not long before he transferred his affections to Leueothoe, daughter of King Orehamus. When Clytic found herself unable to regain her lover, sle infor'med the Persian monareh of his daugh ter's love affair, and he had the unfortunate girl entombed alive. Helios, cnraged at the terrible tragedy, intirely for'sook the nymph whose jealousy had caused it; and she, overwhelmed with grief, lay prone upon the earth for nime days and nights without any sustenance, lier eyes continually following the eourse of her adored sun through the heavens. $\Lambda$ t last the gods, less pitiless than her former admirer, transformed her into a sunflower, and as Ovid says :

"Still the loved object the fond leaves pursue. Still move their root, the moving sun to view."

Robert Browning thus alludes to the story of Rudèl, 
the ancient French poet who adopted this splendid blossom as his emblem :

"I know a mount, the gracious sun perceives First when he visits, last too, when he leaves The world ; and, vainly farored, it repays The day-long glory of his steadfast gaze By no change of its large calm front of snow. And underneath the mount a flower, I know, He cannot have perccived, that changes erer At his approach ; and, in the lost endcavor To live his life, has parted, one by one, With all a flowcr's true graces, for the grace Of being but a foolish mimic sun, With ray-like lorets round a disk-like face. Men nobly call by many a name the mount, As over many a land of theirs its large Calm front of snow, likc a triumphal targe, Is reared; and still with old names fresh ones vie, Each to its proper praise and own account. Men call the flower the sunflower, sportively."

\section{THE SUNFLOWER.}

TIIOMSON.

THE loft follower of the sun,

Sind when he sets, shuts up her yellow leaves, Drooping all uight, and, when he warm returns, Points her enamored bosom to his ray.

\section{TO THE SUNFLOWER.}

PRIDE of the garden, the beauteous, the regal, The crowned with a diadem burning in gold; Sultan of flowers, as the strong-pinioned eagle, And lord of the forest their wide empire hold. 
Let the Rose boast her fragrance, the soft gales perfuming,

- The tulip unfold all her fair hues to me:

Yet though sweet be their perfume, their rainbow dyes blooming,

I turn, noble Sunflower, with more love to thee.

There are some think thy stateliness haughty, disdaining, -

Thy hearen-seeking gaze has no eharm for their eyes. 'Tis beeause the pure spirit within thee that's reigning Exalts thee above the vain pleasures they prize.

Emblem of Constancy, whilst he is beaming,

For whom is thy passion so steadfast, so true; May we, who of faith and of love are aye dreaming, Be taught to remember this lesson by you !

If on earth, like the Sunflower, our soul's best devotion Shall turn to the souree of Truth's far-beaming rays :

Oh! how blest, how triumphant, shall be our emotion, When the bright "Sun of Righteousness" bursts on our gaze.

\section{THE SUNFLOWER.}

\section{E. LANDON.}

Look upon this flower!

It is the symbol of unlappy love;

'T'is saered to the slighted Clytie.

See how it turns its bosom to the sun,

And when dark clouds conceal it, or when night 
Is on the sky, mark how it folds its leaves, And droops its head, and weeps sweet tears of dew,The eonstant sunflower.

\section{THE SUNFLOWER.}

HOOD.

I wILL not have the mad Clytie, Whose head's turned by the sun;

The tulip is a eourtly queen,

Whom therefore I will shun;

The eowslip is a country wench,

The violet is a nun;-

But I will woo the dainty rose,

The queen of every one.

\section{SUNFLOWER.}

SHELLEY.

Lignt-enchanted sunflower ! Thou

Who gazest ever true and tender

On the sun's revolving splendor,

Follow not his faithless glanee

With thy faded eountenanee;

Nor teaeh my beating heart to fear,

If leaves ean mourn without a tear,

How eyes must weep. 


\section{CONSTANCY.}

MOORE.

$\mathrm{OH}$ ! the heart that once truly loves never forgets, But as truly loves on to the close; As the sunflower turns on her god when he sets The same look that she turned when he rose.

\section{REAL FAITH.}

REAL faith is like the sun's fair flower, Which 'midst the clouds that shroud it, and the winds That wave it to and fro, and all the change Of air, and earth, and sky, doth rear its head, And looketh up, still steadfast, to its God.

\section{LAUREL. BAY. \\ (Glory.) \\ (Fame.)}

"We crown with the laurel wreath

The hero-god, the soldier chief."-Euiza Cook.

"Sweet bay-tree, symbol of the song that dreaming poet sings."

IBID.

"The victor's garland, and the poet's crown."-W. Browne.

THE sweet bay was deemed by both Greeks and

1 Romans emblenatic of Victory and Clemency. The glories of all grand deeds were signalized by means 
of laurel erowns; its leaves were deemed very effieacious in the prevention of illness, and its shelter was believed to ward off lightning.

This presumed power is alluded to in the device of the Count de Dunois, which Madame de Genlis mentions as being a bay-tree, with the motto, "I defend the earth that bears me;" and Leigh Hunt, in his "Deseent of Liberty," thus adverts to the belief :

"Long have you my laurels worn, And though some under-leares be torn

Here and there, yet what remains

Still its pointerl green retains,

And still an easy shade supplies

To your calm-kept watchiul eyes.

Only, would you keep it brightening,

And its power to shake the lightning

Harmless down its glossy ears,

Suffer not so many years

To try what they can bend and spoil.»

The laurel bears the classic appellation of Daphne, because of the ancient legend conneeting it with the nymph of that name, who, aeeording to Ovid, was daughter of the river-god Penens. Apollo beheld her, and at once became enamored of her beauty; but Daphne fled from his importunities, and, fearful of being caught, called to Diana for assistanee: she answered her prayers by transforming her into the laurel. Apollo, finding that he held nothing but a hard tree in his embrace, saluted its vivid green leaves with kisses, crowned his head with its leaves, and ordained that ever after that tree should be sacred to his godhead. Ovid thus recomnts this faet:

"I espouse thee for my tree :

Be thou the prize of horor and renown;

The deathless poet and the poem crown. 
Thou shalt the Roman festivals adorn, And, after poets, "be by victors worn."

Spenser resents the slight shown to the god of poetry, and thus rindictively speaks of the cold nympli:

“ Proud Daphne, seorning Phœbus's lovely fire, On the Thessalian shore from him did flee; For which the gods, in their revengeful ire, Did her transform into a laurel-tree."

Chaucer bestows the laurel upon the Knights of the Round Table, the Paladins of Charlemagne, and some other heroes of antiquity,

"That in their times did right worthily. * * * * * *

For:one lefe given of that nuble tree To any wight that hath done worthily Is more honour than anything erthly."

\section{THE LAUREL.}

TASSO.

- O GLAD triumphal bough,

That now adornest conquering chiefs, and now Clippest the brows of overruling kings:

From victory to victory

Thus climbing on, through all the heights of story, From worth to worth, and glory unto glory;

To finish all, $\mathrm{O}$ gentle and royal tree, Thou reignest now upon that flourishing head, At whose triumphant eyes Love and our souls are led. 
THE BAY.

E. COOK.

Whom do we crown with the laurel-leaf?

The hero-god, the soldier chief;

But we dream of the crushing cannon-wheel,

Of the flying sliot and the reeking steel,

Of the crimson plain where warm blood smokes,

Where clangor deafens and sulphur chokes;

Oh, who can love the laurel wreath,

Plucked from the gory field of death ?

* * * * * * *

But there's a green and fragrant leaf

Betokens nor revelry, blood, nor grief ; 'Tis the purest amaranth springing below, And rests on the calmest, noblest brow. It is not the right of the monarch or lord, Nor purchased by gold, nor won by the sword;

For the lowliest temples gather a ray

Of quenchless light from the palm of bay.

O beautiful bay! I worship thee-

I homage thy wreath--I cherish thy tree;

And of all the chaplets Fame may deal, 'Tis only to this one I would kneel.

For as Indians fly to the banian branch

When tempests lower and thunders launch, So the spirit may turn from crowds and strife, And seek from the bay-wreath joy and life. 


\section{THE LAUREL.}

WORDSWORTH.

'Tis sung in ancient minstrelsy

'That Phœebus wont to wear'

The leaves of any pleasant tree

Around his golden hair,

'Till Daphne, despelate with pursuit

Of his imperious love,

At her own prayer transformed, took root

A laurel in the grove.

Then did the penitent adorn

His brow with laurel green;

And 'mid his bright loeks never shorn

No meaner leaf was seen;

And poets sage, in every age,

About their temples wound

The bay, and eonqueror's thanked the gods

With laurel ehaplets crowned.

Into the mists of fabling time

So far runs back the praise

Of beanty, which disclains to elimb

Along forbidden ways;

That scorns temptations, power defies,

Where mutual love is not;

And to the tomb for rescne flies

When life would be a blot. 


\section{PERIWINKLE.}

\section{(Tender Recollections.)}

TN France the Periwinkle, whieh there is sometimes I ealled "the magieian's violet," is eonsidered the emblem of sincere friendship, and as such is mueh used in their language of flowers. 'The English have adopted this evergreen plant as the representative of tender recollections.

In Italy, the country people make garlands of this plant, to place upon the biers of their deeeased ehildren, for whieh reason they name it the "flower of death." But in Germany it is the symbol of immortality; and, beeause its fine, glossy, myrtle-green leaves flourish all through the winter, they term it " winter verdure."

Chaneer repeatedly speaks of it in his "Romaunt of the Rose," even making it one of the ornaments of the God of Love :

" II is garment was every dele

Ipurtraied and wrought with floures,

By divers medeling of coloures ;

Floures there was of many a gise,

Iset by campace in a sise ;

There lacked no floure to iny dome,

Ne not so much as floure of brome,

lie violet. ne eke perevink,

We floure none that men can on think 


\section{WILD FLOWERS.}

ANON.

Despise thou not the wild flower-small it seem,

And of neglected growth, and its light belis

Hang carelessly on every passing gale;

Yet it is finely wrought, and colors there

Might shame the 'I'yrian purple, and it bears

Marks of a care eternal and divine ;

Duly the dews descend to give it food,

The sun revives its drooping, and the showers

Add to its beauty, and the airs of Heaven

Are round it for delight.

\section{DAHLIA.}

(Instability and Pomp.)

TTHE Dahlia is a native of Mexico, where Baron

1 Humboldt found it growing in sandy meadows several hundred feet above the level of the sea. It was brought to England in 1789, but was neglected and the genus lost. It ornamented the royal gardens of the Escurial, at Madrid, for several years before Spanish jealousy would permit it to be introduced into the other countries of Europe.

It derives its name from a conntryman of the celebrated Linnæus, Professor Andrew Dahl, a Swedish botanist: he presented it in 1804 to Lady Holland, who was its first successful English cultivator. 
Its eoarse foliage, gandy flowers, and want of perfume seem to have prevented its becoming a favorite with our poets. Mrs. Sigourney just alludes to it as a florist's flower, in her "Farewell :"

"I have no stately dahlias, nor greenhouse flowers to weep,

But I passed the rich man's garden, and the mourning there was deep,

For the crownless queens all drooping hung amid the wasted sod, Like Boadicea, bent with shame beneath the Roman rod,"

\section{TIIE DAHLIA.}

MARTIN.

THough severed from its native clime,

Where skies are ever bright and clear,

And nature's face is all sublime,

And beauty clothes the fragrant air,

The Dahlia will each glory wear,

With tints as bright, and leares as green ;

And winter, in his savage mien,

May breathe forth storm, - yet she will bear

With all :-and in the summer ray,

With blossoms deck the brow of day.

And thus the soul-if fortune cast

Its lot to live in seenes less bright, -

Should bloom amidst the adverse blast ;-

Nor suffer sorrow's clouds to blight

Its outward beauty-inward light.

Thus should she live and flourish still, 'Though misery's frost might strive to kill

The germ of hope within her quite :Thus should she hold each beauty fast, And bud and blossom to the last, 


\title{
MARIGOLD.
}

\author{
(Grief:) \\ "She droops and mourns, \\ Bedewed as 'twere with tears."
}

George Withers.

TY old English poets these plants are called "golds ;" 1 the name of the Virgin Mary was a very frequent addition in the Middle $\Lambda$ ges to anything useful or beautiful, and so in eourse of time this flower beeame known as the Marigold. In Provence they eall -it gauche fer (left-handed iron), probably from its round, brilliant disk, suggestive of a shield, which is wol'n on the left arm.

Although by itself, however, the Marigold expresses grief, by a judieious mixture with other flowers its meanjng may be greatly varied. For instanee, combined with roses it is symbolic of "the bitter sweets and pleasant pains of lore;" whilst amongst Eastern nations a bouquet of marigolds and poppies signifies "I will allay your pain." Associated with eypress, the emblem of death, marigolds betoken despair.

'The marigold is usually open from nine in the morning till three in the afternoon; this foreshows a continuance of dry weather : should the blossom remain closed, rain may be expected. It shuts at sunset :

"The Marybudde, that shutteth with the light."

Browne, in his "Britannia's Pastorals," says :

"But, maiden, see the day is waxen olde, And "g.ns to suut in with the marygolde." 
Whilst Shakspeare says in "Cymbeline," that when "Phœbus' gins arise," the "winking marybuds begin to ope their golden eyes."

Keats pays more heed to the natural attractions of this flower and sings :

"Open afresh your round of starry folds,

Ye ardent marigolds !

Dry up the moisture of your golden lids,

For great Apollo bids

That in these days your praises shall be sung

On many harps, which he has lately strung;

Anct then again your dewiness he kisses-

Tell him I have you in my world of blisses:

So haply when I rove in some far vale,

His mighty voice may come upon the gale."

Chaucer calls the Marigold a "Golde," and makes a garland of them typical of jealousy, yellow being the cmblematical color of that passion.

\section{THE MARIGOLD.}

G. WITHERS.

WHEN with a serious musing, I behold The grateful and obsequious Marigold, How duly, every morn ng. she displays Her open breast when Phobus spreads his lays; How she observes h:m in his daily walk, Still bending towards him her small slender stalk; How, when he down declines, she droops and mourns, Bedewed as 'twere with tears, till he returns; And low she veils her flowers when he is gone, As if she scornèd to be looked upon 
By an inferior eye; or did contemn

T'o wait upon a meaner light than him :

When this I meditate, methinks the flowers

Have spirits far more generous than ours, And give us fair examples to despise The servile fawnings and idolatries

Wherewith we court these earthly things below,

Which merit not the service we bestow.

But, O my God! though groveling I appear

Upon the ground, and have a rooting here

Which hales me downward, yet in my desire

To that which is abore me 1 aspire,

And all my best affections I profess

To him that is the Sun of Righteousness.

Oh ! keep the morning of his incarnation, 'The burning noon-tide of his bitter passion, The night of his descending, and the height

Of his ascension,-ever in my sight, That imitating Him in what I may,

I never follow an inferior way.

\section{THE LILY.}

(Majesty and Purity.)

THE Lily was sacred to Juno, and is now conse1 crated to the Virgin Mary. It has inspired very lovely poetry. 


\section{A BOUQUET OF LILIES.}

WORDSWORTH.

\section{A LILY flower,}

The old Egyptian's cmblematic mark Of joy immortal and of pure affection.

\section{E. L.}

THE water lilics, that glide so pale, As if with constant care Of the treasures which they bear;

For those ivory vases hold Each a sunny gift of gold.

\section{COWLEY.}

THE virgin lilies in their white, Clad but with the lawn of almost naked white.

\section{WATER-LILIES.}

E. R. B.

Mistr moonlight, faintly falling

O'er the lake at eventide, Shows a thousand gleaming lilies On the rippling watcrs wide.

White as snow, the circling petals Clustcr round each golden star, Rising, falling with the waters, Moving, yet at rest they are. 
Winds may blow, and skies may darken, Rain may pour, and waves may swell; Deep beneath the ehangeful eddies

Lily roots are fastened well.

THE CLOSING LILT.

TENNYSON.

Now folds the lily all her sweetness up, And slips into the bosom of the lake; So fold thyself, my dearest, thou, and slip Into my bosom, and be lost in me.

\section{A DIALOGUE FROM SOLL GARDENING.}

DORA GREEYWEIL.

"THou bearest flowers within Thy hand, 'Thou wearest on 'Thy breast

A flower'; now tell me whieh of these Thy flowers Thou lorest best; Which wilt Thou gather to Thy heart

Belored above the rest?"

"Should I not love my flowers,

My flowers that bloom and pine, Unseen, unsought, unwatehed for hours By any eye but Mine? Should I not love my flowers?

I love my Iilies tall, My Marigold with constant eyes, wach flower that blows, eaeh flower that dies To Me, I love them all. 
I gather to a heavenly bower

My Roses fail and sweet;

I hide within my breast the flower

That grows beside my feet."

UNE PENSÉE.

TOM HOOD.

“There's Pansies : that's for thoughts."-ShaKspeare.

GAY lilies on the virgin breast

Of her who dieth young;

And o'er the warrior gone to rest

Let laurel wreaths be flung;

But strew ye purple pansies when the old man's knell is rung.

Fair types those lily flowers are

Of her for whom ye weep;

Whom earnest prayer and loving care

Could not among us keep;

But strew ye purple pansies when the old man falls asleep !

Well fitting for the warrior dead

The laurels he has won-

Proof of the brave life he has led,

The dangers he has run ;

But strew ye purple pansies when the old man's war is done! 
By all the glances baekward cast

Along life's weary shore-

By all the memories of the past

That may return no more ;

Oh, strew ye purple pansies when the old man's life is o'er!

THE WATER-LILY.

J. II. REYNOLDS.

Is a brook which loved to fret

O'er yellow sand and pebble blue,

The lily of the silvery hue

All freshly dwelt, with white leaves wet.

Away the sparkling water played,

Through bending grass, and blessed flower ;

light and delight seemed all its dower;

Away in merriment it strayed -

Singing, and bearing, hour after hour,

Pale lovely splendor to the shade.

THE STAR AND THE WATER-LILY.

OLIVER WENDELI, HOLMES.

THe Sun stepped down from his goldon throne, And lay in the silent sea,

And the Lily had folded her satin leaves,

For a sleepy thing was she.

What is the Lily dreaming of ?

Why crisp the waters blue?

See, see, she is lifting her varnished lid !

Her white leaves are glistening throngh! 
The Rose is eooling his burning eheek

In the lap of the breathless tide;The Lily hath sisters fresh and fair,

'That would lie by the Rose's side;

Ile would luve her better than all the rest,

And lie would be fond and true ;-But the Lily unfolded her weary lids,

And louked at the sky so blue.

Remember, remember, thou silly one,

How fast will thy summer glide, And wilt thou wither a virgin pale,

Or flourish a blooming bride?

"Olı! the Rose is old, and thorny, and cold, And he lives on earth," said she;

"But the Star is fair, and he lives in the air, And he shall my bridegroom be."

'But what if the stormy cloud should eome, And rufile tlie silver sea?

Would he turn lis eye from the distant sky To smile on a thing like thee?

Oln! no, fair Lily, he will not send One ray from firl-off throne;

The winds shall blow, and the waves shall flow, And thou wilt be left alone.

There is not a leaf on the mountain top, Nor a drop of evening dew, Nor a golden sand on the sparkling shore, Nor a pearl in the waters blue, That he has not cheered with his fickle smile, And warmed with his faithless beam,And will he be true to a pallid flower That floats on the quiet stream? 
Alas for the Lily! she would not heed, But turned to the skies afar, And bared her breast to the trembling ray

That shot from the rising Star;

'The cloud came over the darkened sky,

And over the waters wide :

She looked in vain through the beating rain, And sank in the stormy tide.

\section{THE WATER-LILY.}

J. II. REYNOLDS.

O MELON-SCENTED lily!

O water-queen of flower's!

When shall I see the silver waves

Dancing around thee, like sweet slares

'To Beauty in its bower's ;

When shall I take an earthly part

In honoring thy golden heart?
O pretty rose autumnal !
$O$ fairy queen of trees ?

When may I have thy gentle buds Adornèd with their emerald studs,

In their green palaees;

Whell see thy vernal velvet fall Under thy ruby coronal?

The sound of forest music

The water-song of streams, Are become dim and strange to me As musings of old witchery ; 
But in my fitful dreams, And in my waking weary hours, Spirits come to me, as from flowers.

\section{SWEET-WILLIAM.}

\section{(Gallantry-Finesse.)}

THE Sweet-Willam, a member of the Pink family, 1 from the charming manner in which it arranges its rariegated blossoms into bouquet-shaped clusters, is well worthy of its second name of finesse.

The bearded Pink, as it is sometimes designated, is known to our French neighbors as the "poet's eye," because of the mamner in which its petals are marked.

\section{SWEFT' IVILLIAM.}

COWLEY.

Sweer-Wiliray small, has form and aspect bright; Like that sweet flower that yields great Jove delight. Ifad he majestic bulk he d now be styled Jove's flower" ; and, if my skill is not beguled, He was Jove's flower when Jove was but a child. Take him with many flowers in one conferred, He's worthy Jove, ev'n now he has a beard. 


\title{
T'HE GILI,YFLOWER.
}

\author{
DRAYTON.
}

The curious, choice, clove July flower,

Whose kinds, hight the carnation,

For sweetness of most sovereign power

Shall help my wreath to fashion;

Whose sundry colors of one kind,

First from one root derived,

Them in their several suits I'll bind,

My garland so contrived.

\section{FOXGLOVE.}

\section{(Insincerity.)}

THE Foxglove typifies insincerity, because of the $\mathcal{I}$ insidious poison which lurks within its bright blossom. In France and Germany, and in some parts of England, it is known as "Finger-flower," because of the resemblance it bear's to the finger of a glove, a resemblance which the poets have not failed to take advantage of. William Brown describes Pan as seeking gloves for his mistress :

"To keep her slender fingers from the sunne, Pan through the pastures oftentimes bath runne To pluck the speckled foxgloves from their stem, And on those fingers neatly placèd them. 


\section{THE FOXGLOVE.}

Trre foxglove-leaves, with caution given, Another proof of favoring Heaven

Will happily display:

The rabid pulse it can abate, The heetic flush can moderate, . And, blest by Him whose will is fate, May give a lengthened day.

\section{FOXGLOVE.}

UPON the sunny bank

The foxglove rears its pyramid of bells, Gloriously freckled, purpled and white, the flower That cheers Devonia's fields.

\section{FUCHSIA.}

\section{(Taste.)}

THE Fuchsia, a native of Chili, was named after

1 Leonard Fuchs, a noted German botanist.

As it is quite a modern addition to our gardens, there is little poetry as yet belonging to it. 


\section{THE FUCHSLA.}

ANON.

Besutrfut child of a tropic sun, How hast thou been from thy far home won, 'To bloom in our chilly nortleru air, Where the frost may blight, or the wind may tear?

Dost thou not pine for thine own dear land, For its cloudless skies-for its zephyrs bland, For its graceful flowers of matchless hues, Bright as the dreams of an Eastern muse?

Dost thou not pine for the perfumed air, For the gorgeous birds that are hovering there; For the starry skies, and the silver moon, And the grasshopper's shrill and unchanging tune?

Doth thy modest head as meekly bend In thine own bright clime,-or doth exile lend To thy fragile stalk its drooping grace, Like the downcast look of a lovely face?

No! thou would'st murmur, were language thine, It is not for these I appear to pine ; Nor for glorions flowers, nor cloudless skies, Nor yet for the plumage of rainbow dyes.

The kindly care I have met with hereThe dew that is soft as affection's teal, Would have soothed, if sorrow had bent my head, And life and vigor around me shed. 
But I do not pine, and I lo not grieve;

Why should I mourn for the things I leave?

I feel the sun and the gladsome air,

And all places are joyous if they be there.

And thus in the world we may happy be,

Not in climate, nor valley, nor islet free;

But wherever the tenderest love in our breast

May have objects around it on which it can rest.

\section{HEATH.}

(Solitude.)

\section{MOORLAND BLOSSOMS.}

ELIZA COOK.

TJILD blossoms of the moorland, ye are rery dear to me;

Ye lure my dreaming memory as clover does the bee;

Ye bring back all my childhood loved, when freedom, joy, and health

Had nover thought of wearing chains to fetter famc and wealth.

Wild blossoms of the common land, brave tenants of - the earth,

Your breathings were among the first that helped my spirit's birth ; 
For how my busy brain would dream, and how my heart would burn,

Where gorse and heather flung their arms above the forest fern.

* $* \begin{array}{llllll}* & * & * & * & * & *\end{array}$

Who loved me then? Oh! those who were as gentle as sineere,

Who never kissed my cheek so hard as when it owned a tear.

Whom did I love? Oh! those whose faith I never had to doubt;

Those who grew anxious at my sigh and smiled upon my pout.

What did I erave? The power to rove unquestioned at my will ;

Oh! wayward idler that I was !--perchance I am such still.

What did I fear? No ehance or change, so that it did not turn

My footstep from the moorland coast, the heather, and the fern.

Methinks it was a pleasant time, those gipsy days of mine,

When youth with rosy magic turned life's waters into wine;

But nearly all who shared those days have passed away from earth,

Passed in their beauty and their prime, their happiness and mirth.

So now, rich flowerets of the waste. I'll sit and talk to ye,

For memory's casket, filled with gems, is opened ly your key; 
And glad I am that I ean grasp your blossoms sweet and wild,

And find myself a doter yet, a dreamer, and a child.

\section{ON A SPRIG OF IIEATTH.}

MRS. GRANT.

FLower of the waste! the heath-fowl shuns

For thee the brake and tangled wood,-

To thy proteeting shade she runs,

Thy tender buds supply her food;

Her young forsake her downy plumes

To rest upon thy opening blooms.

Flower of the desert though thou art!

The deer that range the mountain free,

The graceful doe, the stately hart,

Their food or shelter seek from thee;

The bee thy earliest blossom greets,

And draws from thee her ehoicest sweets.

Gem of the heath ! whose modest bloom

Sheds beauty o'er the lonely moor ;

Though thou dispense no rich perfume,

Nor yet with splendid tints allure,

Both valor's erest and beauty's power

Oft hast thou deeked, a favorite flower.

Flower of the wild! whose purple glow

Adorns the dusky mountain's side,

Not the gay hues of Iris' bow,

Nor garden's artful, varied pride, 
With all its wealth of sweets eould eheer,

Like thee, the hardy mountaineer.

Flower of his heart! thy fragrance mild, Of peace and freedom seems to breathe; To pluek thy blossoms in the wild, And deek his bonnet with the wreath, Where dwelt of old his rustic sires, Is all his simple wish requires.

Flower of his dear-loved native land ! Alas, when distant, far more dear ! When he, from some eold foreign strand, Looks homeward through the blinding tear, How must his aehing lieart deplore That home and thee he sees no more.

\section{HEATH.}

How oft, though grass and moss are seen 'Tanned bright for' want of showers, Still keeps the ling its darksome green, Thick set with little flowers.

\section{THE LILAC.}

\section{(The Joy of Youth.)}

NE of our sweetest spring flowers. It will not live long when separated from its parent tree. 
THE LILAC.

THOMSON.

SHRUBs there are,

- . That at the call of Spring

Burst forth in blossomed fragrance; lilacs, robed

In snow-white innocence or purple pride.

\section{THE LILAC.}

THE lilac, various in array-now white,

Now sanguine, and her beauteous head now set

With purple spikes pyramidal ; as if,

Studious of ornament, yet un resolved

Which hues she most approves, she chose them all.

\section{THE LILAC.}

MRS. SIGOURNEY.

Lilac of Persia! Tell us some fine tale Of Eastern lands; we're fond of travelers. Have you no legends of some sultan proud, Or old fire-worshiper? What, not one note Made on your voyage? Well, 'tis wondrous strango That you should let so rare a chance pass by, While those who never journeyed half so far Fill sundry volumes, and expect the world To reverently peruse and magnify What it well knew before! 
THE LILAC.

BURNS.

Он, were my love yon lilac fair Wi' purple blossoms in the spring; And I a bird to shelter there,

When wearied on my little wing.

How wad I mourn when it was torn By autumn wild and winter rude! But I wad sing on wanton wind, When youthfu' May its bloom renewed.

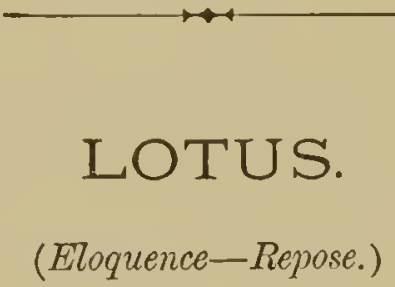

"The lotus-flower, whose leaves I now

Kiss silently, Far more than words can tell thee, how

I worship thee."-Moore.

\section{THE LOTUS.}

\section{TENNYSON.}

TOW sweet it were, hearing the downward stream 1 With half-shut eyes ever to seem

Falling asleep in a half dream !

To dream and dream, like yonder amber light, Which will not leave the myrrh bush on the height; 
To hear each other's whispered speech ;

Eating the Lotus, day by day.

To watch the crisping ripples on the beach,

And tender curving lines of creamy spray;

To lend our hearts and spirits wholly

To the influence of mild-minded melancholy ;

'To muse and brood and live again in memory,

With those old faces of our infancy

Heaped over with a mound of grass,

'Two handfuls of white dust, shut in an urn of brass.

The Lotus blooms below the flowery peak;

The Lotus blows by every winding creek;

All day the wind breathes low, with mellower tone;

Through every hollow cave and alley lone,

Round and round the spicy downs the yellow Lotus dust is blown.

We have had enough of action and of motion, we

Rolled to starboard, rolled to larboard, when the surge was seething free,

Where the wallowing monster spouted his foam fountains in the sea.

Let us swear an oath, and keep it with an equal mind, In the hollow Lotus land to live and lie reclined On the hills like gods together, careless of mankind; For they lie beside their nectar, and the bolts are hurled Far below them in the valleys, and the clouds are lightly curled

- Round their golden houses, girdled with the gleaming world,

Surely, surely slumber is more sweet than toil; the shore

Than labor in the deep mid-ocean, wind and wave and oar ;

Oh! rest ye, brother mariners; we will not wander more. 


\section{SWEET PEAS.}

\section{(Delicate Pleasures.)}

$T^{T}$ is singular that few of our poets have celebrated 1 these exquisite flowers. We know only thcse pretty lines of Keats, which exactly portray thcm :

"Here are sweet peas, on tiptoe for a flight ;

With wings of gentle flush o'er delicate white, And taper fingers catching at all things, To bind them all about with tiny rings."

\section{IVY.}

(Friendship.)

\section{$\sqrt{\text { OORE says : }}$}

"When the ivy of friendship is green in our souls."

Dickens assumes the same mcaning.

\section{THE IVY GREEN.}

\section{c. DICKENS.}

$\mathrm{OH}$, a dainty plant is the ivy green,

'That creepeth o'er ruins old;

Of right choice food are his meals, I ween,

In his cell so lone and cold. 
The wall must be crumbled, the stones decayed, To pleasure his dainty whim;

And the moldering dust that years have made

Is a merry meal for him.

Creeping where no life is seen,

A rare old plant is the ivy green.

Fast he stealeth on, though he wears no wings, And a staunch old heart has he :

How closely he twineth, how tight he clings

To his friend, the huge oak-tree!

And slyly he traileth along the ground,

And his leaves he gently waves,

And he joyously twines and hugs around

The rich mold of dead men's graves.

Creeping where no life is seen,

A lare old plant is the ivy green.

Whole ages have fled, and their works decayed,

And nations scattered been,

But the stout old ivy shall never fade

From its hale and hearty green.

The brave old plant in its lonely days

Shall fatten upon the past,

For the stateliest building man can raise

Is the lvy's food at last.

Creeping where no life is seen,

A rare old plant is the ivy green. 
IVY.

CALDER CAMPBELL.

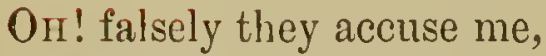

Who say I seek to check

The growing sapling's flourishing;-

I better love to deck

The dead and dying branches

With all my living leaves.

'T'is for the old and withered tree

'The Iry garlands weares.

\section{GROUND IVY.}

AND there upon the sod below

Ground Ivy's purple blossoms show,

Like helmet of crusader knight

In anther's closs-like form of white.

\section{THE IVY.}

BARTON.

HAST thou seen, in winter's stormiest day,

The trunk of a blighted oak,

Not dead, but sinking in slow decay

Beneath 'Time's resistless stroke,

Round which a luxuriant ivy had grown,

And wreathed it with verdure no longer its own? 
Pcrehance thou hast secn this sight, and then, As I at thy ycars might do,

Passed carelessly by, nor turned again

That scathèd wreck to view.

But now I can draw from that moldering tree Thoughts which are soothing and dear to me.

Oly! smile not, nor think it a worthless thing If it be with instructions fraught; That which will closest and longest cling

Is alone worth a serious thought!

Should anght be unlovely which thus can shed Grace on the dying, and leaves on the dcad?

\title{
AMARANTH.
}

\author{
(Immortality.) \\ "Immortal amaranth."-MrrToN.
}

TOS'T poctical of all flowers in meaning is the 1. Amaranth. It has been selected as the symbol of immortality, and has ever been associated with Death as the portal through which the soul must pass to Eternity. Milton gives crowns of amaranth to the angelic multitude asscmbled before the Deity:

"To the ground

With solemn adoration down they cast

Their crowns inwove with amaranth and gold.

Immortal amaranth - a flower which once

In Paradise, fast by the tree of life,

Began to bloom : but soon for man's offonse 
To heaven removed, where first it grew, there grows And flowers aloft, shading the fount of life, And where the river of bliss, through midst of heaven Rolls o'er Elysian flower's her amber streain : With these that never fade the spirits elect Bind their resplendent loeks enwreathed with beams; Now in loose garlands thiek thrown off, the bright Pavement, that like a sea of jasper shone, Impurpled with celestial rosy sinile."

These flowers, if gathered and dried, will long preserve their beauty.

One of the most popular speeies of the amaranth is the "Love-lies-bleeding." The origin of this singular appellation is not known, but it has been suggested that the following verses of Campbell aeeount for it. 'The daughter of $\mathrm{O}^{\circ} \mathrm{Comnor}$ is lamenting over the tomb of Comnoeht Moran:

"A hero's bride? this desert bower, It ill befits thy gertle breeding:

And wherefore dost thou love this flower

To eall 'My-love-lies-bleeding'?"

"This purple flower my tears have nursed;

$\Lambda$ hero's blood supplied its bloom :

I love it, for it was the first

That grew on Connocht Moran's tomb."

THE AMARANTH.

SIIEILLEY.

Whose sad inhabitants each year would come

"With willing steps, climbing that rugged height, And hang long locks of hair, and garlands bound With amaranth flowers, which, in the clime's despite, 
Filled the frore air with nnaccustomed light. Such flowers as in the wintry menory bloom Of one friend left, adorned that frozen tomb.

\section{ASPEN.}

(Lamentation.)

"And full of emotion, its fault doth deplore, Sigh, shrer, and quiver, and droop evermore."

Eleanor Darby.

7 He Trembling Poplar is now generally known as L the Aspen. It is chicfly remarkable for the ceaseless tremulous motion of its leaves-a natural phenomenon, to account for which many very diverse explanations have been proffered. Miss Darby, in her "Lays of Love and Heroism," has thus rersified a German legend upon the subject :

"The Lord of Life walked in the forest one morn,

When the song-wearied nightingale slept on the thorn;

Not a breath the deep hush of the dawning hour broke,

Yet every tree, even the firm knotted oak,

The tall warror pine, and the cedar so regal,

The home of the stork and the haunt of the eagle,

All the patriarehal kings of the forest adored,

And bowed their proud heads at the sight of the Lord.

"One tree, and one only, continued ereet,

Too vain to show even the Saviour respect!

The light giddy aspen its leafy front raised,

And on the Redeemer unbendingly gazed. 
Then a eloud, more of sorrow than wrath, dimmed the brow Of Him to whom everything living should bow ; While to the offender, with shame now opprest, He breathed in these words the eternal behest :

" "Alas for thy fate! thon must suffer, poor tree, For standing when others were bending the knee. Thou'rt doomed for thy fault an atonement to pay : Heneeforth be a rush for the wild winds to sway. Sigh, sport of their fury, and slave of their will ! Bow, e'en in a calm, when all othèr's are still! And shivering, quivering, droop evermore, Beeause thou wouldst not with thy brothers adore.'

"The weak aspen trembled, turned pale with dismay, And is pallid with terror and grief to this day. Each tremulous leaf of the penitent tree Obey's to this moment the heavenly decree.

'Tis the sport of the wild winds, the slave of their will ; E'en without a breeze bends, when all ot her's stand still ; And full of emotion, its fault doth deplore.

Sigh, shiver, and quiver, and droop cvermore."

\section{THE ASPEN TREE.}

CHARLES SWAIN.

WHY tremblest thou, Aspen ? no storm threatens nigh ; Not a cloud mars the peace of the love-beaming sky; 'Tis the spring of thy being-no autumn is near T'hy green boughs to wither, thy sweet leares to sear! The sun, like a crown, o'er thy young head shines free; Then wherefore thus troubled?' what fearest thou, fair tree?

I have watched through the mildest, the stillest of hours,

When Nature slept soft on her pillow of flowers; 
When, though all things appeared 'neath her influence blest,

Thou alone wert disturbed, thou alone couldst not rest !

But still, as lamenting some dreadful decree, I'hou groanedst in the calm, llke an outcast lone tree! A roice from its leaves seemed to wail on mine ear, "List, mortal ; attend the dark source of my fear ; Al, learn the dread hour when we sank neath rebuke, And our boughs, as if grasped by a hurricane, shook! When the morn rose in blood, when the dead wept around,

And a curse 'gainst our seed burst in woe from the ground !-

"The Cross, amidst lightning on Calvary stained, Was made from our roots; there IHis blood hath remained !

Creation, accursing, in misery spoke, And a shudder eternal then first o'er us broke!

From the serpent we're named, the last doomed to be. tray!

Oh! no rest for the Aspen tıll earth fades away!" 


\section{CORNFLOWER.}

\section{(Deticacy.)}

"Now, gentle flower, I pray thee tell

If my lover loves me, and loves me well."

Axonymous.

r THE classic name of the bright blue Cornflower is 1 cyanus; and it was so named after a worshiper of Flora, who made garlands for public festivities out of various sorts of wild flowers, and who lingered from morn till eve amid the corn, weaving the blossoms that she had collected. Its petals are used for divination, as the thistle-down is.

This flower, although now so common in our cormfields, is thought not to be indigenous, but to have been brought from the East among some imported grain.

Its deep blue hue is so deep that it almost approaches a purple, and as such the poet addresses it:

"There is a flower, a purple flower, Sown by the wind, nursed by the shower, O'er which Love breathed a powerful spell, The truth of whispering hope to tell. Now, gentle flower, I pray thee tell If my lover loves me, and loves ine well : So may the fall of the morning lew Keep the sun from fading thy tender blue." 


\section{FIELD FLOWERS.}

\section{CAMPBELL.}

Ye field flowers! the gardens eelipse you, 'tis true, Yet, wildlings of nature, I dote upon you;

For ye waft me to summers of old,

When the earth teemed around me with fairy delight, And when daisies and buttercmps gladdened my sight; Like treasures of silver and gold.

I love you for lulling me back into dreams Of the blue Highland mountains and echoing streams, And of birchen glades breathing their baln ; While the deer was seen glaneing in sunshine remote, And the deep mellow crush of the wood-pigeon's note Made music that sweetened the calm.

Not a pastoral song has a pleasanter tune Than ye speak to my heart, little wildlings of June ; Of old ruinous castles ye tell :

I thought it delightful your beanties to find When the magic of nature first breathed on my mind, And your blossoms were part of lier spell.

Even now what affections the violet awakes!

What loved little islands, twice seen in her lakes,

Can the wild water-lily restore.

What landseapes I read in the primrose's Tooks, What pietures of pebbled and minnowy brooks In the vetehes that tangle the shore? 
Earth's eultureless buds! to my heart ye were dear Ere the fever of passion, or ague of fear, Had seathed my existence's bloom ; Once I welcome you more, in life's passionless stage, With the visions of youth to revisit my age, And I wish you to grow on my tomb.

\section{CYPR כSS.}

\section{(Mourning.)}

"The cypress is the emblom of mourning."-SHAKSPEARE.

A COORDING to Ovid, this tree was named after A Cyparissus, an especial favorite of Apollo. $\mathrm{He}$ had accidentally slain his pet stag. and was so sorrowstricken that he besought the gods to doom his life to everlasting gloom; and they, in compliance with his request, transformed him into a cypress-tree.

"When, last in tears, the blood his reins forsakes,

His every limb a grassy hue partakes ;

ITis flowing tresses, stiff and bushy grown,

Point to the stars, and taper to a cone.

Apollo thus : 'Ah ! youth, beloved in vain, Long shall thy boughs the gloom I feel retain;

Henceforth, when mourners grieve, their grief to share, Emblem of woe, the cypress shall be there." 


\section{THE CYPRESS WREATH.}

SIR W. SCOTT.

O Lidy, twine no wreath for me, Or twine it of the eypress-tree! Too lively glow the lilies light, 'The varnished holly's all too bright, The May-flower and the eglantine May shade a brow less sad than mine; But, lady, weave no wreath for me, Or weare it of the eypress-tree.

Let dimpled Mirth his temples twine With tendrils of the laughing vine; 'The manly oak, the pensive yew,

- 'To patriot and to sage be due; 'The myrtle bough bids lovers live, But that Matilda will not give; 'Then, lady, twine no wreath for me, Or twine it of the eypress-tree.

Let merry England proudly rear Her blended roses, bought so dear ; Let Albin bind her bonnet blue With heath and harebell dipped with dew ; On favored Erin's erest be seen The flower she loves of emerald greenBut, lady, twine no wreatl for me, Or twine it of the eypress-tree.

Strike the wild harp, while maids prepare The ivy meet for minstrel's hair ; And while his erown of laurel leaves With bloody hand the victor weaves, 
Let the loud trump his triumph tell ;

But when you hear the passing bell, 'Then, lady, twine a wreatl for me, And twine it of the cypress-tree.

Yes! twine for me the cypress bough ;

But, O Matilda, twine not now!

Stay till a few brief montlis are past, And I have looked and loved my last!

When villagers my shroud bestrew

With pansies, rosemary, and rue,Then, lady, weave a wreath for me, And weave it of the cypress-tree.

\section{THE CYPRESS-TREE.}

BLACKWOOD'S MAGAZINE.

A SLENDER tree upon a height in lonely beanty towers, So dark, as if it only drank the rushing thunder showers;

When birds were at their erening hymms, in thoughtful reverie,

I've marked the shadows deep and loug, from yonder cypress-tree.

I've thought of oriental tombs, of silent cities, where In many a row the cypress stands, in token of despair; And thought, beneath the evening star, how many a maiden crept

From life's discordant scene, and o'er the tomb in silence wept. 
I've thought, thon lonely eypress-tree, thou hermit of the grove,

IIow many a heart, alas! is doomed forlorn on carth to rove;

When all that charmed the morn of life, and cheered the youthful inind,

IIare like the sunbeans passed away, and left but clouds behnd !

'Thon wert a token unto me, thou stem with dreary leaf, So desolate thou look'st," as earth were but a home of grief!

A few short years shall swiftly glide, and then thy boughs shall wave,

When tempests beat and breezes sigh, above my silent grave!

\section{THISTLE.}

\section{(Independence.)}

"The thistle shall bloom on the bed of the brave."-Avon.

A S the national emblem of Seotland the Thistle has A been celebrated, far-and wide, by the many bards of its brave people. There is some little doubt as to how this flower was first adopted by the Scots. Some patriotic anthors go baek to the days of the Picts in order to trace the origin of its use, and adduce a romantic legend in proof of the antiquity of the eustom. Be this as it may, the Plantagenets were not prouder of 
the broom than were the Stuarts of their thistle; and princes of the royal house were wont to wear the Clansau-pheidh, as it is ealled in Gaclie, with all the respeet that its presumed antique and honorable history cntitled it to. The poets of Scotland are ever ready to pay it homage, and the following thoroughly eharacteristic poem, to be found in Hogg's 'Jacobite Relics,' is supposed to have been written by the Ettrick Shepherd himself •

" - Let them boast of the country gave Patrick his fame, Of the land of the ocean and Anglian name,

With the red blushing roses and shamroek so green ; Far deare r to me are the linls of the North, The land of blue mountains, the birthplace of worth : Those mountains where Freedom has fixed her abode, Those wick-spreading glens where no slave ever trod,

Where blooms the red heather and thistle so green.

" 'Though rich be the soil where blossoms the rose, And barren the mountains and corcred with snows

Where blooms the red heather and thistle so green; Yet for friendship sineere, and for loyalty true, And for courage so bold which no foe could subdue, Unmatched is our country, mrivaled our strains, And lovely and true are the nymplis on our plains,

Where rises the thistle, the thistle so green.

" Far-famed are our sires in the battles of yore, And many the eaimies that rise on our shore O'er the foes of the land of the thistle so green : And many a cairnie shall rise on our strand, Should the torrent of war ever burst on our land; Let foe eome on foe, as wave comes on wave, We'll give them a welcome, we'll give them a grave

Beneath the red heather and thistle so green.

" "Oh! dear" to onr souls as the blessings of Heaven Is the freedom we boast, is the land that we live in, 
The land of red heather and thistle so green;

For that land and that freedom our fathers have bled, And we swear by the blood that our fathers have shed, No foot of a foe shall e'er treacl on their grave ;

But the thistle shall bloom on the bed of the brave,

'The thistle of Scotland, the thistle so green.'

"There appears to be no proof of this sturdy flower" having been adopted as the symbol of Scotland earlier than the middle of the fifteenth century, when a puritanic council held a solemn consultation within the walls of the old Council-house at Edinburgh as to the advisability of erasing the papistic figure of St. Gileswhich for so many centuries had been triumphantly borne through the battle and the breeze-from the old standard: religious animosity gained the day, and the time-honored figure of the saint was replaced by the thistle."-J. INGRAM.

\section{CLOVER;}

OR,

SHAMROCK.

\section{(I Promise.)}

7 HE white Clover, or Shamrock, is the national 1 emblem of Ireland, and claims an equal place in history with England's rose or Scotland's thistle. This symbol of their country is worn by Irishmen on the anniversary and in commemoration of St. Patrick's landing near Wicklow, in the beginning of the fourth cen- 
tury of the Christian era. The patron saint is reported to have explained to his disciples the mysteries of the Trinity by means of a clover-leaf, or trefoit.

"Brave sons of Hibernia, your shamrocks display, Forever made saered on St. Patrick's day ; 'Tis a type of religion, the badge of our saint, And a plant of that soil which no venom can taint.

"Both Venus and Mars to that land lay a claim, Their title is owned and recorded by fame ; But St. Patrick to friendship has hallowed the ground, And made hospitality ever abound.

"Then with shamrocks and myrtle let's garrish the bowl, In eonverse convivial and sweet flow of soul ; To our saint make oblations of generous wineWhat saint could have more ?-sure, 'tis worship divine!

" 'Tho' jovial and festive in seeming excess, We've hearts sympathetie of others' distress: May our shamrocks continue to flourish, and prove An emblem of charity, friendship, and love.

"May the blights of disunion no longer remain, Our shamroek to wither, its glories to stain ; May it flourish forever, we Heaven invoke, Kindly sheltered and fenced by the brave Irish oak !"

Bees delight in the sweet-scented blossoms of what Tennyson aptly calls the

"Rare 'broidery of the purple clover."

Walter Thornbury has given us the followir: fretty lyric, "In Clover:"

"There is clover, honey-sweet, Thick and tangled at our feet ; Crimson-spotted lies the field, As in fight the warrior's shield: 
Yonder poppies, full of scorn,

Proudly wave above the eorn;

There is musie at our feet

In the elover, honey-sweet.

"You may traek the winds that blow

Through the cornfields as they go ;

From the wheat, as from a sea,

Springs the lark in eestasy.

Now the bloom is on the blade,

In the sun and in the shade,

There is musie at our feet

In the elover, honey-sweet."

The Druids held the clover in great repute, deeming it, it is supposed, a charm against evil spirits. Hope. was depicted by the ancients as a little child standing on tiptoe, and holding one of these flowers in his hand.

\section{DEAD LEAVES.}

(Melancholy.)

"Ah me! a leaf with sighs ean wring My lips asunder."-E. B. Brownina.

ELI,A INGRAM.

THE withered leaves, trembling, love, .

L Fill to the ground;

And strewn over all, love,

Lie dying around, 
Killed by the frost, love, The flowers scattered lie; 'Their brigh tness is lost, And neglected they die.

'The world it looks dreary, love, $\Lambda$ nd thick falls the rain ; $\mathrm{My}$ heart it is weary, love, My head throbs with pain. My hopes thickly fail, love, Like the leaves from a tree, And I cannot recall

Their beauty to me.

With thy heart I am blest, love,

So I'll brave the chill rain ; And patiently rest, love,

Till the sun shines again. And I hope when the Spring, love,

Gives leaves to the tree, Some flowers it will bring, love, For you and for me.

\section{WITHERING-WITHERING.}

HOFFMAN.

WITHERING-withering-all are witheringAll of Hopes flowers that youth hath nursedFlowers of love too early blossoming ? Buds of ambition too frail to burst. 
Faintly-faintly-oh ! how faintly

I feel life's pulses ebb and flow:

Yet sorrow, I know thou dealest daintily

With one who should not wish to live moe.

Nay! why, young heart, thus timidly shrinking,

Why doth thy upward wing thus tire?

Why are thy pinions so droopingly sinking,

When they should only waft thee higher?

Upward-upward let them be waving,

Lifting the soul toward her plaee of birth :

There are guerdons there, more worth thy having-

Far niore than any these lures of the earth.

\section{MISTLETOE.}

\section{(I surmount Difficulties.)}

"The sacred bush."-TENyYson.

7 HE Mistletoe seareely requires more than a passing A allusion; every one is acquainted with that re. markable eustom which permits any lad to exaet from any lass the toll of one kiss, when they accidentally meet where

"Sacred ceilings, dark and gray,
Bear the mistletoe."

In IIolstein the eountry people eall the mistletoe " the specter's wand," from the supposition that holding a branch of it will not only enable a man to see ghosts, but force them to speak to him. 


\section{THE MISTLETOE.}

Oy Christmas-eve the bells were rung, On Christmas-eve the mass was sung ; That only night in all the year

Saw the stoled priest the chalice near. The damsel donned her kirtle sheen; The hall was dressed with holly green : Forth to the woods did merry men go, To gather in the mistletoe; Then opened wide the baron's hall To vassal, tenant, serf, and all.

\section{UNDER THE MISTLETOE.}

UNDER the mistletoe, pearly and green, Meet the kind lips of the young and the old; Under the mistletoe hearts may be seen Glowing as though they had never been cold. Under the mistletoe, peace and goodwill Mingle the spirits that long have been twain; Leaves of the olive-branch twine with it still,

While breathings of hope fill the loud carol strain. Yet why should this holy and festival mirth

In the reign of old Christmas-tide only be found? Hang up love's mistletoe over the earth, And let us kiss under it all the year round.

Hang up the mistletoe over the land

Where the poor dark man is spurned by the white; Hang it wherever Oppression's strong hand

Wrings from the helpless liumanity's right; 
Hang it on high where the starving lip sobs, And the patrician one turneth in scorn; Let it be met where the purple steel robs Child of its father, and field of its corn. Hail it with joy in our yule-lighted mirth, But let it not fade with the festival sound; IIang up love's mistletoe over the earth, And let us kiss under it all the year round!

\section{PASSION-FLOWER.}

(Faith. When the flower is reversed it means Superstition.)

THIS exquisite flower is the symbol of Faith. It is supposed to represent the instruments of the Crucifixion ; hence its name.

\section{TIIE PASSION-FLOWER.}

AlL-Ben uteous flower! whose center glows With studs of gold; thence streaming flows Ray-like effulgence; next is seen A rich expanse of varying hue, Enfringed with an empurpled blue, And streaked with young Pomona's green. 
High o'er the pointal, decked with gold, (Emblem mysterious to behold !)

A ridiant cross its form expands ; Its opening arms appear to embraco The whole collective human race, Refuse of all men, in all lands.

\section{TO THE PASSION - FLOWER.}

BARTON.

IF superstition's baneful art First gave thy mystic name, Reason, I trust, would stecl my heart Against its groundless claim ;

But if, in fancy's pensive hour, By grateful feelings stirred, Her fond imaginative power That name at first conferred,-

Though lightly truth her flights may prize, By wild vagary driven, For once their blameless exercise

May surely be forgiven.

We roam the seas-give new-found isles

Some king's or conqueror's name:

We rear on earth triumphant piles

As meeds of earthly fame:-

We soar to heaven; and to outlive Our life's contracted span, Unto the glorious stars we give The names of mortal man : 
Then may not one poor floweret's bloom The holier memory share Of Him who, to avert our doom, Vouchsafed our sins to bear?

God dwelleth not in temples reared By work of human hands, Yet shrines august, by men revered, Are found in Christian lands.

And may not e'en a simple flower Proclaim His glorious praise, Whose fiat, only, had the power Its form from earth to raise?

Then freely let; thy blossom ope Its beauties--to recall

A scene which bids the humble hope In Him who died for all!

\section{THE PASSION-FLOWER.}

ANON.

ITs tender shoots, fostered with eare, extend

Far in festooned Juxurianee, Its drooping flowers, to blend,

Sweet mixture! modesty and loveliness;

But more-when elosely viewed, this flower appears To bear the saered mark of sacred tears,

Adding to the plant's beauty-holiness. 
How like this flower can woman be, so fair !

So beautiful! too delicate her mind

Would seem, the world's rude withering frost to bear

Without some guardian's help, round whom to bind

Its tendrils in purc trusting confidence.

When rightly trained her blossoms bloom, they shine

In more than beauty's luster ; they combine

With earthly charms, cclestial innocence,

Breathing of saered things : yet, like that flowcr, alone To those who view her near, her holiness is known.

\section{HOLLY.}

(Foresight.)

"I, in this wisdom of the holly-tree, can emblems see."-Southey. TIIIS trce is sacred to Christmas and domestic
mirth.

\section{THE HOLLY-TREE.}

SOUTIEY.

O reader ! hast thou ever stood to sce

The holly-tree?

The eye that contemplates it wcll perccives

Its glossy leaves,

Ordered by an Intclligence so wise

As. might confound the atheist's sophistries. 
Below a eireling fenee its leaves are seen,

Wrinkled and keen;

No grazing eattle through their priekly round

Can reach to wound;

But, as they grow where nothing is to fear,

Smooth and unarmed the pointless leaves appear.

I love to riew these things with eurions eyes

And moralize;

And, in this wisdom of the holly-tree,

Can emblems see,

Wherewith perehanee to make a pleasant rhyme,

One which may profit in the after-time.

Thus, though abroad, perehanee, I might appear Harsh and austere,

To those who on my leisure would intrude

Reserved and rude,

Gentle at home amid my friends I'd be.

Like the high leaves upon the holly-tree

And should my youth, as youth is apt. I knows

Some harshness show,

All vain asperities I day by day

Would wear away,

Till the smooth temper of my age should ine

Like the high leaves upon the holly-tree.

And as, when all the snmmer trees are seen

So bright and green,

The holly leaves a sober hue display,

Less bright than they;

But when the bare and wintry woods we see,

What then so eheerful as the Holly tree?- 
So, serious should my youth appear among

The thoughtless throng:

So would I seem among the young and gay

More grave than they,

That in my age as cheerful I might be

As the green winter of the holly-tree.

\section{THE HOLLY.}

ELIZA COOK.

THE holly ! the holly ! oh, twine it with the bay.Come, give the holly a song;

For it helps to drive stern Winter away,

With his garments so somber and long.

It peeps through the trees with its berries of red,

And its leaves of burnished green,

'Vhen the flowers and fruits have long been clead,

And not even the daisy is seen.

l'hen sing to the holly, the Christmas holly,

'I'hat hangs over peasant and king;

While we laugh and carouse 'neath its glittering bovghs,

To the Christmas holly we'll sing.

The gale may whistle, and frost may come

'To fetter the gurgling rill :

The woods may be bare and the warblers dumb-

But the holly is beautiful still.

In the revel and light of princely halls

The bright holly-branch is found;

And its shadow falls on the lowliest-falls

While the brimming horn goes round. 
The iry lives long, but its home must be Where graves and ruins are spread; 'There's beauty about the cypress-tree,

But it flourishes near the dead;

The laurel the warrior's brow may wreathe,

But it tells of fears and blood.

I sing the holly -and who can breathe

Aught of that that is not good?

\section{HAREBELL.}

(Submission and Grief.)

THIS lovely blossom merits its first meaning, but A scarcely its last. Those who have listened to the faint, sweet rustle of its bells when the breeze passes over them, might rather think it a mirthful than a sad flower. And yet such has been generally the fancy it has given birth to in the poets. Witness the following charming verses :

\section{THE HAREBELL.}

R. IIEBER.

WITH drooping bells of clearest blue Thou didst attract my childish view, Almost resembling

The azure butterflies that flew

Where on the heath thy blossoms grew. So lightly trembling. 
Where feathery fern and golden broom Increase the sand-rock cavern's gloom,

I've seen thee tangled, 'Mid tufts of purple heather bloom, By vain Arachne's treacherous loom, Vith dewdrops spangled.

'Mid ruins tumbling to decay, 'Thy flowers their lreavenly hues display,

Still freshly springing

Where pride and pomp have passed away, On mossy tomb and turret gray,

Like friendship clinging.

When glow-worm lamps illume the scene, And silvery daisies dot the green,

Thy flowers revealing,

Perchance to soothe the fairy-queen, With faint sweet tones, on night serene, Thy soft bells pealing.

But most I love thine azure braid, When softer flowers are all decayed, And thou appearest Stealing beneath the hedgerow shade, Like joys that linger as they fade, Whose last are dearest.

Thou art the flower of memory ; The pensive soul recalls in thee The year's past pleasures ; And led by kindred thought will flee, Till back to careless infancy

'The path she measures. 
Beneath autumnal breezes bleak, So faintly f:air, so sadly meek,

I've seen thee bending;

Pale as the pale blue veins that streak Consumption's thin transparent cheeris,

With death hues blending.

Thou shalt be sorrow's love and mine. The violet and the eglan tine

With spring are banished:

In summer's beam the roses sinne; But I of thee my wreath will twine, When these are vanished.

\section{THE HAREBELL.}

CAROLINE SYMONDS.

IN Spring's green lap there blooms a flower Whose cup imbibes each vernal showror, 'That sips fresh Nature's balmy dew, Clad in her sweetest, purest blue; Yet shines the ruddy eye of morning, The shaggy wood's brown shade adorning. Simplest floweret! Child of May ! Though hid from the broad eye of day, Doomed in the shade thy sweets to shed, Unnotieed droop thy languid head : Still Nature's darling thou'lt remain; She feeds thee with her softest rain; Fills each sweet bud with honeyed tears, With genial gales thy bosom cheers. 
Oh ! then, unfold thy simple charms in yon deep thicket's sheltering arms.

Far from the fieree and sultry glare,

No heedless hand shall harm thee there;

Still, then. aroid the gaudy seene,

The flaunting sun, the embroidered green,

And bloom and fade with ehaste reserve, unseen.

THE HAREBELL.

SCOTT.

"For me,"-she stooped, and, looking round, Plueked a blue harebell from the ground,-

"For me, whose memory searce eonveys

An image of more splendid day's,

This little llower, that loves the lea,

May well my simple emblem be;

It drinks heaven's dew blithe as the rose

'That in the king's own garden grows;

And when I plaee it in my hair,

Allan, a bard, is bound to swear

He ne'er saw eoronet so fair." 


\section{BROOM.}

\section{(Humility.)}

"The memorial flower of a princely race."

$G$ EOFFRY, Count of Anjou, acquired the surname a sprig of broom in his helmet on a day of battle. This Geoffry was second husband to Matılda, or Maud, Empress of Germany and daughter of Henry I. of England; and from this Plantagenet family were descended all our Edwards and Henrys.

It could not be expected that so romantic a story would escape the poets, and accordingly we find it embalmed in the following verses:

"Time was when thy golden chain of flowers

Was linked, the warrior's brow to bind;

When reared in the shelter of royal bowers,

Thy wreath with a kingly coronal twined.

"The ehieftain who bore thee high in his erest,

And bequeathed to his race thy simple name,

Long ages past has sunk to his rest,

And only survives in the rolls of fame.

"Though a feeble thing that Nature forms,

A frail and perishing flower art thou;

Yet thy raee has survived a thousand storms

That have made the monareh and warrior bow.

" The storied urn may be erumbled to dust, And time may the marble bust deface; But thou wilt be faithful and firm to thy trust,

The memorial flower of a prinecly race." 


\section{VERVAIN.}

\section{(You enchant me.)}

TERVAIN, or wild verbena, has been the floral symbol of enchantment from time immemorial. It was styled "saered herb" by the Greeks, who aseribed a thousand marvelous properties to it, one of whieh ras its power of reecnciling enemies. Under the influenee of this belief, they, as did also the Romans, sent it by their ambassadors on treaties of peaee; and whenever they dispatehed their heralds to offer terms of reeonciliation, renewal or suspension of hostilities, one of them invariably bore a sprig of vervain. In his "Muses' Elysium," Drayton ealls it "holy vervain," and thus speaks of it:

"A wreath of velvain heralds wear Amongst our garlands named.

Being sent that weighty news to bear of peace or war proclaimed."

The peoples of antiquity also frequently used this plant in various kinds of divinations, saerifiees, and ineantations ; and its specifie name of verbena originally signified a herb used to decorate altars. Ben Jonson says :

"Bring your garlands, and with reverence place The vervain on the altar."

It was mueh valued by the Druids, being regarded by them as only seeond to the mistletoe: they used it largely in their divinations and casting of lots. 
Sir William Darenant, in his poem of "Gondibert," alludes to its curative powers:

" Black melancholy rusts, that fed despair

Through wounds' long rage, with springled vervain cleared; Strewed leaves of willow to refresh the air,

And with rich fumes his sullen senses cheered."

Vervain is used still amongst the Cornish peasantry as a charm against ague.

In gathering the vervain for "good luek," the herb is first crossed with the hand, and then blessed, thus:

" Hallowed be thou, vervain, As thou growest in the ground;

For in the Mount of Calvary

There thou first wast found."

\section{SWEET SEDGE.}

\section{(Resignation.)}

RUSH bearing is still kept up in the north-west of R England. Our ancestors strewed their rooms and churehes with rushes, and of these, sweetest of all was the Sedge.

It is well chosen for resignation, as when trodden on its ineense to God is sweetest. 
THE SWEET SEDGE.

C.ALER CAMPBELI.

O river-side,

Where soft green rushes bear dark flowers, And reedy grasses weave dark bowers,

'Through which flect minnows glide-

O river banks, let me from you convey

Something to seatter in yon ancient minster gra $y$.

\section{O minster gray!}

Where graves of friends beloved are found, I come to thee with strewments. - Round

Each blade of grass, each spray

of Aeorus, a fragrant essence breathes, Nature's own ineense shed to sanctify these wreaths!

O rushes green,

With blossoms wan or brown!-and ye Siweet flags, from whose seent-roots to me

Come thoughts of the Has Been, Ye are the fitting plants at eve to shed A vague mysterious perfume o'er the silent dear!

"Not so !- not so !"

$\Lambda$ roice replies: "Fol" joy alone These reeds and rushes here are strown!"

But I again ery : "Lo!

Joy's emblems here I fitly use, to prove That life and death alike spring from Cool's holy love." 


\section{FLOVER DIALOGUES.}

I love you....................A Red Rose.

I love you, and it causes me both pleasure and pain...........A Dog Rose.

I love you silently...............A Red and White Rose.

I share your sentiments............Garden Daisy.

You may hope.................. Meadow Daisy.

Speak out................... Oxlip.

You may hope................. Snoudrop.

I am sorry ................... Purple IIyacinth.

I share your sentiments ............ Double China Aster.

Do you love me ?.................... Coxcomb.

If you love me, you will find out......Maiden-blush Rose.

I dare not love you................ Veronica Speeiosa and Rose.

I live for thee.................. Cedar leaf.

I do not love you ............... Breaking off and throu-

I die if neglected.................. Laurestinus. ing au'ay rose petals.

I offer you my frimithip........... Sprig of Acacia or Iry leaves.

Try to forget me............... Moonwort.

Remember me................ Forget-me-not.

Be frank with me................An Osier.

I give you the truest friendship .....A leaf of Oak-leaved Geranium.

Try to save me............... Chicory and Nareissus.

Be assured of my brotherly (or sisterly)

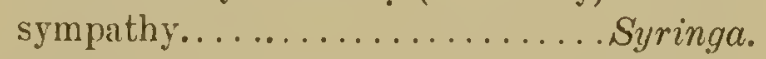

Fly with me................... Venus' Ear.

Don't talk nonsense-I think you silly. Purple Columbine or Pomeyranile flower's. 
Be my Valentine................. Crocus.

You are always delightful ........... Cineraria.

I am very angry with you ........... s sprig of Furze.

I have just remembered ............ China Aster.

Seeond thoughts are best .......... China Aster.

I agree to it.................... Straw.

I an foolishly anxious. ............Red Columbine.

Will you grant the an interview ?.... Pimpernel.

How dare you $! . . \ldots \ldots \ldots \ldots \ldots$. . Sprig of Larch.

You are a miser .................. Scurlet Auricula.

Be prudent..................Ziphion Spinosum.

Be warned in time-Beware $. . \ldots . .$. Echites-also Parpurea.

Be mine .....................Fonr-leaved Clover.

You are betrayed................ White Catchfly.

Beware $! . \ldots \ldots \ldots \ldots \ldots \ldots$. Olcander.

Beware of a false friend ............ Francisca Latifolia.

I am in bonds................ Convolvalus (dead) if in prison; living, if of lor'e.

You boast.....................Hydrangea.

Call me not beautiful.............. Rose unique.

It is a ealumny................ Ilellebore.

Beware of slander................ Oleander and Helleborc.

Be merry..................... Yellow Crocuscs.

Come down to me................. Jacob's Ladder.

Be comforted................... Scarlet Geranium.

Could you bear proverty ?.... ........Broulallia Jamisonii.

Do not fear. ................... Poplar learcs.

You are in danger............... Rhododendron.

It is a dangerous pleasure.......... Tuberose.

Tour friond is deeeitful............ Ivy and Dogsbane.

Stop-Wait................... Enpatorinm.

Depart..................... Dandclion puff-ball.

I desire to please you.............. Mezereon.

Despair not; God is everywhere...... White Jnlienne.

It is diffieult . . .............. Blackthorn.

I arn disappointed .............. Carolina Syringa.

You have my disdain..............Rue, or Ycllow Carnation.

You are a good little housewife ....... Flax and Thrift.

Will you be a domestic: wife ?.........Flax and Honeysuckle.

Do not despise my poverty........... Shepherd's Purse. 
Do not refuse me ............... Eschscholtzic.

I doubt you................... Apricol blossom.

i envy you................... The Bramble.

You are mistaken.............. Bee Orchis or Fly Orchis.

I can give you estcem; not love...... Spiderworl and Slrawberry tree.

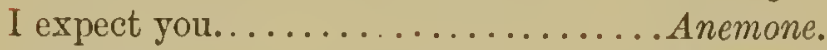

Forget me ...................Moonwort.

I hope you may prosper.............Flowering Almond and Beech leares.

Dine with us.................... Oak leares.

I am your captive................Peach blossom.

Be silent.................... White Rose.

I declare against you ............Wild Tansy.

I desire a return of affection......... Jonquil.

I am so mueh obliged to you......... Mtint.

I feel your hospitality . . . .....Fllax.

I offer you my fortuine, or, I will Iend you money................ Calceolaria.

Give me a kiss ... ... . . . ..... Mistletoe.

Do make haste ... ........... Yellow Balsam.

Pray do: please do .. . ......... Burdock leaf.

I am independent ........... Thislle.

I don"t care for it . . . . . . . . . Candytuft.

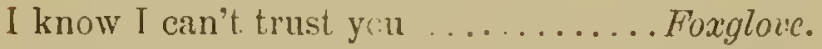

You are very feeble .............. Dahlin.

I feel very jealous................. French Murigold.

Are you jealous ?................ Yellow Rase.

Be happy..................... Wood Sorrel.

Keep your promise. .............. Pelunirl.

What shall I do ? ............... Aspen.

Let me go....................Bullerfly Weed.

Be inerry.................... Shamrack.

Live for me.................... Arbor Vitce.

I love you................... Myrlle.

I am forsaken ................... Willou.

Make haste..................... Dianthus.

My regrets will fo:low you to the grave Asphodel. Ruserlinsy.

Romember me............... Rosemary.

Marry me....................American Lindin. 
I am very unhappy

Dead leares, dark Geranium.

You are very clever............... Clematis.

Your happiness won't last ........... Virginian Spiderwort.

Never despair...................Watcher by the Wrayside.

Be friends.................... Sprig of Hazel.

Do make up our quarrel............ Fitbert.

I forbil you.................... Sprig of Privet.

I promise to protect you.............Bearded Crepis.

Pray for me.. .................. White Verbena.

Take care..................... Golden Rod.

I prophesy that you will marry soon...Marigold, Woodbine, and Blackithorn.

Success crown your wishes.......... Coronella.

For shame................... Peony.

We must part.................. Carolina Jessamine.

Such worth is rare ...............Achimenes.

You surprise me................ Truffe.

I suspect you.................... Champignon.

Accept my sympathy.............Balm.

Thanks...................... Agrimony.

The variety of your conversation de-

lights me.................. Clarkia.

Thee only do I love................ Arbutus.

I will think about you............. Pansy.

Tell the truth ............... White Chrysanthemum.

I cannot accept your love........... Scabious.

Unitc against our enemics .......... Scarlet Verbena.

Don't be greedy................. Lnipine.

Watch...................... Dame Violet.

Will you accompany me to the East ?. .Stephanotis.

Will you dance with me?........... White Hyacinth.

You are cold ................. Hortensia.

You are my dearest pet .............Mignonnette.

I change but in death.............Boy leaf.

Adieu, but remember me...........A broken flower and " Pansy. 


\section{BOUQUETS.}

I.-Remember our rendezvous, but beware of a false friend.

1. Remembrance ............Rosemary.

2. Rendezvous.............Chickweed.

3. Beware of false friends...... Franciscea Latifolia.

II. - Our unexpected meeting left but transient impressions.

Answer.-Vulgar minds soon forget.

1. Unexpected meeting......... Lemon Geranium.

2. Transient impressions....... Withered White Rose.

3. Vulgar minds..............African Mrarigold.

t. Forgetfulness.............Moonwort.

III.-My fortitude forsook me on your rerusal to be mine.

1. Fortitude .............. Dipteracanthus Spectabilis.

2. Forsaken...............Laburnum.

3. Refusal................ Striped Carnation.

4. Be mine................. Four-leaved Clover.

IV.-Do not refuse to come down and comfort my solitude.

1. Do not refuse............. Eschscholtzia.

2. Come down................Jacob's Ladder.

3. Comfort.................Pear Tree.

4. Solitude................Heath. 
D.-Your affectation and deceit I disdnin.

1. Affectation............. Coxcomb imuranth.

2. Deceit................Fly-trap.

3. Disdain............. Yellow Carnation.

VI. - I love to disappoint your curiosity.

1. Love..... . . . . . . . . . Red Rose.

2. Disappoint... . . ...... Carolina Syringa.

3. Curiosity ............. Sycamore.

VII.--I am doeile and dejeeted, do not refuse me.

1. Docile ...............Rush.

2. Dejected...............Lichen.

3. Do not refuse ............ Carrot Flower.

VIII.-I hope you may be happy, and offer you pecuniary aid.

1. Hope ................ Flowering Almond.

2. May you be happy......... Volkamenia.

3. Offer pecuniary aid........ Calceolaria.

IX.--Be temperate in your taste.

1. Tempcrance............Azalex.

2. Taste................. Scarlet Fuchsia.

X.--Let the bonds of marriage unite us.

1. Bonds.................. Blue Convolvulus.

2. Marriage.............. Ivy.

3. Unite us...............A few whole Strows.

XI.--Meet me to-night; do not forget.

1. Neet me. ............ Everlasting I'ex.

2. To-night . . .......... Night Conveluains.

3. Do not forget............ Forget-me-not. 
XII.--I w sep for your indifference, and : $: n$ melincholy on accomnt of your coldness.

1. I weep for you............. Purple Verbena.

2. Intifferenec... . . . . . . . . . . Ifustard Seed.

3. Melancholy.............. Dead Leaves.

4. Coldness ................. Agnus Castus.

XIII.-1. .... Lunds of marriage unite us.

1. Bonds..................Blue Convolvulues.

2. Marriage............. Iry.

3. Unite us ...............A ferw whole Straws.

XIV.-Farewell! give me your good wishes. Forget me not.

1. Farewell .............. Sprig of Spruce Fir.

2. Give me your gool wishes. . Sweet Basit.

3. Forget me not............ Forget-me-not.

X V.--Your patriotism, courage, and fidelity merit. crerlasting remembrance.

1. Patriotism..............Nasturtium.

2. Courage ............ Oak Leaves.

3. Fidelity ................ Heliotrope.

4. Everlasting Remembrarce...Everlasting, or Immortelles.

XVI.-Your frirolity and malevolence will cause you to be forsaken by all.

1. Frivolity. ............... London Pride.

2. Malevolence..............Lobelia.

3. Forsaken................Laburnum.

The flowers should be bound together with a fading leaf.

XVII. - Be assured of my sympathy. May you find consolation.

1. Be assured of my symrathy. . Thrift.

2. Consolation. ........... Red Poppy. 
XVIII.-- By foresight you will surmount your difficulties.

1. Foresight .............. Holly.

2. You will surmount your difficulties..................Mistletoe.

XIX.-Your insincerity and avarice make me hate you.

1. Insincerity ........... Cherry Blossom, or Foxglove.

2. Avarice................. Scarlet Auricula.

3. IIatred................. Turti's Cap.

XX.-Beware of deceit. Danger is near. Depart.

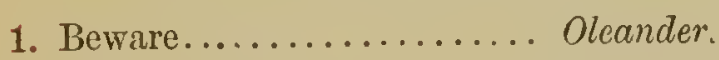

2. Deceit.................White Flytrap.

3. Danger is near...........Rhododendron.

4. Depart............... Dandelion, or Thistle Seed-head.

XXI.-You are fickle, indiscreet, and affected. Therefore you are hated.

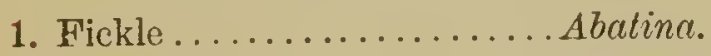

2. Indiscreet ..............Almond Blossom.

3. Affected................. Cockscomb.

4. Hated................ Basil.

XXII.-Humility, meekness, and tinth have won the love I give to thee only.

1. Humility. ............. Small Bindweed.

2. Mrcekness ..............Birch.

3. Truth................ White Chrysanthemum.

4. Have won............. Parsley.

5. Love for thee only..........Arbutus. 


\title{
MODIFICATIONS
}

\author{
OF
}

THE FLOWER LANGUAGE.

TF a flower be given reversed, its original significa1 tion is understood to be contradieted, and thc opposite meaning to be implied.

$\Lambda$ rosebud dirested of its thorns, but retaining its lcarcs, conveys the sentiment, "I fear no longer; I hope:" thorns signifying fears, and leaves, hopes.

Stripped of leaves and thorns, the bud signifies, "Therc is nothing to hope or fear."

The cxpression of flowers is also varied by changing thcir positions. Place a marigold on the head, and it significs "Mental anguish;" on the bosom, "Indifference."

When a flowcr is given, the pronoun $I$ is understood by bending it to the right hand; thou, by inclining it to the left.

"Yes" is implied by touching the flower given with the lips.

"No," by pinching off a petal, and casting it away.

"I am" is expressed by a laurcl-leaf twisted round the bouquet.

" "I have," by an iry-leaf folded together.

"I offer you," by a ]caf of the Virginian Crcepcr.

To win-a sprig of parsley in the bouquet.

"May," or "I desire "-an ivy tendril round the bouquet 


\section{FLOWER GAME.}

TAVE a large bouquet ready; let each person draw 1 from it a flower, and the meaning attached to it will typify the future consort's character. For example:-Say your bouquet for Spring consists of Violcts, Hyacinths, Primroses, Daisies, Heart's-ease, Hawthorn, Daffodils; then the characters would be

Violet, modest; Hyacinth, playful ; Dark Hyacinth, mouruful ; Primrose, simple, candid; Daisy, an early riser; Heart's-ease, kind, cliaritable, or thoughtful ; Hawthorn, hopeful ; Daffodil, daring.

\section{For SuMMER.}

Rose, loving ; White Rose, secret and canny ; Pink, haughty; Jasmine, elegant or amiable ; Lily, pure ; Mignonnette, clever; Tulip, proud, conceited; Stock, hasty; Mezereon, a flirt; Foxglove, deceitful ; Myrtle, devoted ; Laurel, brave; a Reed, musical; Hollyhock, ambitious, Marigold, rich ; Poppy, lazy ; Cornflower, extravagant; Dead Leares, old; Geranium, stupid ; Mimosa, nervous; Thistle, patriotic ; Thyme, merry ; Aster, changeable; Oak-leaf, hospitable.

The profession of the destined lover will be found thus:-Lily, a person of rank ; Rose, an artist ; Thistlc, a Scotchman, and a soldier; Oak-leaf, a farmer; Laurel, a poet ; Foxglore, a lawyer ; Cypress, a doctor ; Tulip, a freeholder; Passion-flower, a clergyman; Mirigold, a merchant ; Shamrock, an Irishman ; Leek, a Welshman. 
Of comrse the persons who draw the flowers are supposed to be ignorant of their meaning; or they may draw blindiolded.

In winte: this game may be playca with painted flower eards; painting a pack would be a ploasant livme amuscinent; or dried flowers gumuseri on carces would answer perfectly well. The player inon draw a card instead of a fiower. 



\section{THE VOCABULARY.}

\section{PART TIIE FIRST.}

ABECEDART .............. Volubility.

Abatina..................Fickleness.

Acacia...................Friendship.

$\Lambda$ cacia, Rose or White..........Eleganee.

Acacia, Yellow............. Seeret love.

Acanthus................ The fine cirts. Artifice.

Acalia................... Temperanee.

Achillea Millefolia.........War.

Achimenes Cupreatr.......... Such worth is rare.

Aconite (Wolfsbane)........... Misanthropy.

Aconite, Crowfoot............ Luster.

Adonis, Flos ............. Sad memories.

African Marigold............ Vulgar minds.

Agnus Castus.............. Coldness. Indifferenee.

Agrimony ................. Thankfulness. Aratitude.

Almond, Common............ Stupidity. Incliseretion.

Almond, Flowering........... Hope.

Almond, Laurel.............. Perfidy.

Allspice................. Compassion.

Aloe................... Grief. Religiones Superstition.

\section{Bitterness.}

Althæa Frutex (Syrian Mallow). I'ersuasion.

Alyssum, Sweet ............ Worth beyond beauty.

Amaranth, Globe............. Immortality. Ulufading love.

Amarauth (Cockscomb)......... Foppery. Affectation.

Amaryllis................. Pride. Timidity. Splencliclbeauty.

Ambrosia.................. Love returned.

American Cowslip........... Divine beauty. 
American Elm............... Patriotism.

American Linden ............ Hatrmony.

American Starwort.........Welcome to a stranger. Cheer-

fulness in old age.

Amethyst ................Admiration.

Andromeda............... Self-sacrifice.

Anemone (Zephyr Flower)..... Sickness. Expectation.

Anemone, Garden............Forsaken.

Angelica................. Inspiration, or Magic.

Angrec ................. Royalty.

Apocynum (Dogsbane)........ Deceit.

Apple .................... Temptation.

Apple Blossom.............Preference. Fame speates hini great and good.

Apple, Thorn...............Deceitful charms.

Apricot Blossom............ Doubt.

Arbor Vitæ.............. Unchanging friendship. Live for $M e$.

Arbutus ................. Thee only do I love.

Arum (Wake Robin) ........Ardor. Zeal.

Ash-leaved Trumpet Flower.... Separation.

Ash, Mountain............Prudence, or With me you are safe.

Ash Tree Grandeur.

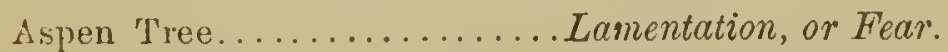

Aster (China).............. Variety. After-thought.

Asphode $1 . . . . . . . . . . . .$. My regrets follow you to the grave.

Auricula. Painting.

Auricula, Scarlet............Avarice.

Auricula, Yellow.............Splendor.

Autumnal Leaves............. Melancholy.

Azalea.................. Temperance.

Bachelor's Button........... Celibacy.

Balm.................... Sympathy.

Balm, Gentle..............Pleasantry.

Balm of Gilead.............. Cure. Relief.

Balsam, Red.............. Touch me not. Impatient resoives. 
Balsam, Yellow.............Impatience.

Barberry .. ............. Sharpness of temper.

Basil . Hatred.

Bay Leaf................. I change but in death.

Bay (Rose) Rhododendron...... Danger. Beware.

Bay Tree.................. Glory.

Bay Wreath.............. Revoard of merit.

Bearded Crepis.............Protection.

Beech Tree................ Prosperity.

Bee Orchis................Industry.

Bee Ophrys................ Error.

Begonia................. Deformity.

Belladonna ................ Silenee. Hush!

Bell Flower, Pyramidal........ Constancy.

Bell Flower (small white)...... Gratitude.

Belvedere............... . declare against you.

Betony................... Surprise.

Bilberry................ Treachery.

Bindweed, Great ........... Insinuation. Importunity.

Bindweed, Small........... Iumility.

Birch. . . . . . . . . . . . . . . Meekness.

Birdsfoot (Trefoil).......... Revonge.

Bittersweet (Nightshade)......Truth.

Black Poplar............... Courage. Afliction.

Blackthorn............... Diffieulty.

Bladder Nut Tree............ Frivolity. Amusement.

Bluebottle (Centaury) ......... Delicacy.

Bluebell.................. Cunstancy. Sorronful regret.

Blue-flowered Greek Valerian. Rupture.

Bonus Henricus............ Goodness.

Borage................. Bluntness.

Box Tree................ Stoicism.

Bramble..................Lowliness. Envy. Remorse.

Branch of Currants........... You please all.

Branch of Thorns........... Severity. Rigor.

Bridal Rose.............. IIappy love.

Broom..................Iumility. Neatness.

Browallia Jamisonii.......... Could you beur poverty?

Buckbean................ Calm repose.

Bud of White Rose.......... A heart ignorant of love. 
Buglos................. Falsehood.

Bulrush................. Indiscretion. Doeility.

Bundle of Reeds, with their $\mathrm{Pa}$ -

nicles................ Music.

Burr.................. Rudeness. Youvearyme.

Burdock............... Importunity. Touch me not.

Buttercup (Kingeup).......... Ingratitude. Childishness.

Buttercups................ Riches.

Butterfly Orchis.............Gayety.

Buttertly Weed.............. Let me go.

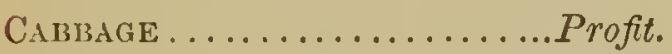

Cacalia..................Adulation.

Cactus.................Wrimth.

Calla Athiopica..............Mrgnificent beauty.

Calceolaria............... I offer you pecuniary assistanee, or $I$ offer you my fortune.

Calycanthus................Benevolence.

Camellia Japonica, Red....... Unpretending exellence.

Camellia, White............Perfeeted loveliness.

Campanula Pyramida.........Aspiring.

C'amphire................ Fragrance.

Canary Grass................Perseverance.

Candytuft . .............. Indifference.

Canterbury Bell.............Aeknovoledgment.

Cupe Jasmine............. I am too happy.

Cardamine. . ..............Paternal error.

Carnation, Deep Red...........Alas! for my poor! heant.

Carnation, Striped...........Refusal.

Carnation, Yellow...........Disduin.

Cardinal Flower............ Distinction.

Catchfly................... Snare.

Catchfly, Red.............. Youthful love.

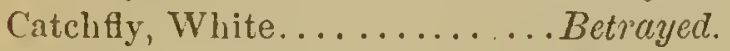

Cattleya................. Mature charms.

Cattleya, Pineli....................

Cedar..................... Strength.

Cedar of Lebanon............ Incorruptible.

Cedar I.eaf. ............... I live for thce.

Celandine, Lesser............ Joys to como. 
Cereus, Creeping............Modest genius.

Centaury.................. Dclicacy.

Chamomile................ Encrgy in adversity.

Champignon .............. Suspicion.

Checkered Fritillary........ Persecution.

C'herry Tree, White..........Good education.

C'herry Blossom............. Insincerity.

Chestnut Tree............... Do mo justice.

Chinest, Primrose .......... Lasting love.

Chickweed................ Rendczvous.

('hicory..................Frugality.

China Aster............... Varicty.

China Aster, Double......... I partake your sentiments.

China Aster, Single..........I vill think of it.

China or Indian Pink.......... Aversion.

C'hina Kose................ Beauty alroays new.

Chinese Chrysanthemum....... Cheerfulness under adversity.

Chrorozema Varium.......... You have many lovers.

Christmas Rose.............. Relieve my anxiety.

Chrysanthemum, Red........I love.

Chysanthemum, White.......Thuth.

Chrysanthemum, Yellow....... Slighted love.

Cineraria.................. Always delightful.

Cinquefoil .................Maternal affection.

Circæa.................. Spell.

Cistus, or Rock Rose. ........ Popular favor.

Cistus, Gum.............. shull dic to-morrow.

Citron ..................lll-natured bcauty.

Clarkia................. The variety of your conversation delights me.

Clematis................Mental bcauty. Artificc.

Clematis, Evergreen...........Poverty.

Clianthus................Worldlincss. Self-seeking.

Clotbur................. Rudcness. Pertinacity.

Cloves................... Dignity.

Clover, Four-leaved............ Be mine.

Clover, Red.............. Intustry.

Clover, White............Think of me. Promise.

Cobæa................... Gossip. 
Cockscoml (Amaranth)......... Foppery. Affectation. Singularity.

Colchicum, or Meadow Saffron. . My best days are past.

Coltsfoot................. Justice shall be clonè.

Columbine................ Folly.

Columbine, Purple........... Resolved to win.

Columbine, Red.............. Anxious and trembling.

Convolvulus .............. Bonds.

Convolvulus Bl., Minor... ....Repose. Night.

Convolvulus Major............ Extinguished hopes.

Convolvulus, Pink........... Worth sustaincd by judicious and tender affection.

Corchorus................. Impatient of absence.

Coreopsis................. Alwoays cheerful.

Coreopsis Arkansa........... Love at first sight.

Coriander.................. Hidden worth.

Corn....................Riches.

Corn, Broken.............. Quarrel.

Corn Bottle ............... Delieacy.

Corn Cockle. . ............. Gentility.

Cornflower................. Delicaey.

Corn Straw................ Agreement.

Cornel Tree............... Duration.

Coronella .................Success crown your wishes.

Cosinelia Subra........... The charm of a blush.

Cowslip................Pensiveness. Winning grace.

Youthful beauty.

Cowslip (American) .......... Divine beauty.

Crab (Blossom)............. Ill nature.

Cránberry. ............... Cure for heartache.

Creeping Cereus............. Horror.

Cress.....................Stability. Powor.

Crocus....................Abusc not. Impatience.

Crocus, Spring............. Youthful gladness.

Crocus (Saffron) .............Mirth. Checrfulness.

Crown Imperial..............Majesty. Power.

Crowsbill.................Envy.

Crowfoot................. Ingrutituie.

Crowfoot (Aconite-leaved) ..... Lustri'

Cuckoo Plant...............Ardor. 
Cudweed, American.......... Unceasing remembranee.

Currant. ............... Ihy frown will kill me.

Cuscuta ...............Mcanness.

Cyclamen............... Diffidenee.

Cypress.................Death. Mourning.

DAFFODIL...............Regard. Unrequited love.

Dahlia................. Instability. Pomp.

Daisy.................. Innocence and Hope.

Daisy, Garden.............. I share your sentiments.

Daisy, Michaelmas............Furewell, or Afterthought.

Daisy, Parti-colored ..........Beauty.

Daisy, wild.............. I will think of $i t$.

Damask Rose.............. Brilliant eomplexion.

Dandelion............... Rustic oracle.

Dandelion, or Thistle-seed-head Depart.

Daphne..................Glory. Immortality.

Daphne Odora.............. Printing the lity.

Darnel.................. Viee.

Dead Leaves................Sadness.

Deadly Nightshade...........Frlsehood.

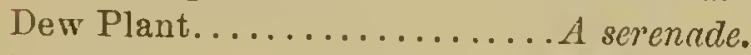

Dianthus ............... Mrake haste.

Diosma................ Four simple elegance charms in:

Dipteracantlıus Spectabilis..... Fortitude.

Diplademia Crassinoda. ........ Fou are too bold.

Dittany of Crete.............Birth.

Dittany of Crete, White.......Passion.

Dock .................. Patience.

Dodder of Thyme............ Basencse.

Dogsbane............... Deecit. Falsehood.

Dogwood.................Durability.

Dragon Plant.............. Snare.

Dragonwort. . . . . . . . . . . Horror.

Dried Flax.............. Utility.

Erony Tree................. Blnekness.

Eclites Atropurpurea..........Be varned in time.

Eglantine (Sweetbrier)......... Pretry. Troonend to heal.

Elder...................Zealuusness. 
Elm $\quad \ldots \ldots \ldots \ldots \ldots \ldots$ Dignity.

Enchanter's Nightshade...... Witchcraft. Sorcery;

Eudire.................. Frugality.

ischischoltzia .............. Do not refusc me.

Eupatorium............... Delay.

Erening Primrose............ Silent love.

liver-bowing Candytuft........ Indifference.

Evergreen Clematis............Poverty.

Evergreen Thorn............. Sulace in adversity.

Everlasting............... Never-ceasing remembrance.

Everlasting Pea............. Lasting pleasure.

FenNel.................. Wrorthy all praise. Strength.

Fern .................. Fascination. Magic. Sinerity.

Ficoides (Ice Plant)........... Iour looks freezc me.

Fig..........................

Fig Marigold............... Idleness.

Fig Tree............... Prolific.

Filbert .................Rcconciliation.

Fir.................... Time.

Fir Tree................ Elevetion.

Flax.................. Domestic industry. Fate. Ifecl your kindness.

Flax-leaved Golden-locks . .... Tardiness.

Fleur-de-Lis .............. Fllıme. Iburn.

Fleur-de-Luce............... Fire.

Flowering Fern ............Reverie.

Flowering Reed............. Confidence in Hlcaver.

Flower-of-an-Hour........... Delicate beauty

Fly Orchis................ Error.

Flytrap............... Deceit.

Fool's Parsley.............. Silliness.

Forget-me-not............. Forget me not.

Foxglove................ Insincerity.

Foxtail grass.............. Sporting.

Franciscea Latifolia.......... Bevoare of false friends.

French Honeysuckle.......... Rustic beauty.

French Marigold ............ Jealousy.

French WVillow........... Bravery and Humanity.

Frog Ophrys.............. Disgust. 
Fuller's 'Teasel................ Miscanthropy.

Fumitory ............... Spleen.

Fuchsia, Scarlet........... Taste.

Furze, or Gorse............. Love for all seasons. Anger.

GARDEN Anemone..........Forsaken.

Garden Chervil.............. Sineerity.

Garden Daisy.............. I partake your sentiments.

Garden Marigold ........... Uneasiness.

Garden Ranunculus .......... You are rieh in attractions.

Garden Sage...............Esteem.

Garland of Roses........... Revoard of virtue.

Gardenia.................Refinement.

Gentian.................. I love you best when you are sad.

Germander Speedwell ......... Facility.

Geranium................Deceit.

Geranium, Dark...........Melaneholy.

Geranium, Horseshoe-leaf...... Stupidity.

Geranium, Ivy .............. Bridal Favor.

Geranium, Lemon........... Unexpected meeting.

Geranium, Nutmeg........... Expected meeting.

Geranium, Uak-leaved.........Thue friendship.

Geranium, Penciled............ Ingenuity.

Geranium, Rose-scented... ....Preference.

Geranium, Scarlet........... Comforting.

Geranium, Silver-leaved.......Recall.

Geranium, Wild............. Steadfast piety.

Gilly flower................ Bonds of affection.

Gladioli...................Ready armed.

Glory Flower................ Glorious beauty.

Goat's Rue...............Reason.

Golden Rod................Preeaution.

Gooseberry................Anticipation.

Gourd.................Extent. Bulk.

Grammanthus Chloraflora...... Your temper is too hasty.

Grape, Wild ..............Charity.

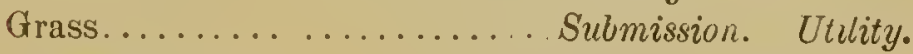

Guelder Rose..............Winter.' Age.

HAND Flower Tree.........W Warning. 
Harebell.................. Submission. Grief.

Hawkweed............... Quick-sightedness.

Hawthorn............... Hope.

Hazel.................. Reeonciliation.

Ileartsease, or Pansy ......... Thoughits.

Heath .................... Solitude.

Helenium................ Tears.

Heliotrope............... Devotion; or, I turn to thee.

Hellebore................ Scandal. Calumny.

Helmet Flower (Monkshood). ... Knight errantry.

Ilemlock................... You viill be my death.

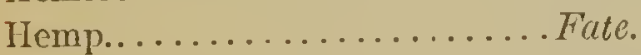

IIenbane................. Imperfection.

Hepatica ................. Confidence.

Hibiscus.................. Delicate beauty.

Holly................... Foresight.

Holly Herb.............. Enehantment.

Hollyhock................. Ambition. Feendity.

Ifonesty..................Honesty. Fascinution.

Honey Flower. ............. Lnve secet and seert.

Honeysuckle............... Generous and devoted affection.

Honcysuckle, Coral...........The color of my filte.

IIoneysuckle, Frenclı......... Riustic beauty.

Hop.................... Injustice.

Hornbeam ............... Ornnment.

Horse Chestnut............ Luxury.

Hortensia................. Fon are cold.

Houseleek............... Vivreity. Domestic industry

Houstonia................ Content.

Hoya ................. Sculpture.

Hoyabella................ Contentment.

Humble Plant.............. Despondency.

II undred-leaved Rose......... Dignity of mind.

Hyacinth................ Sport. Game. Play.

Hyacinth, Purple............ Sorrowful. I am surry.

Hyacinth, White............ Unobtrusive loveliness.

Hydrangen................. boaster.

IIyssop ................. Cleantiness.

ICELAND MIOSS............ Ilcalth. 
lce Plant .................. Your look's frecze me.

Imbricata............... Uprightness. Stentiments of honor.

Imperial Montague..........Ponocr.

Indian Cress. ............. Warlike trophy.

Indian Jasmine (Ijomœa) ...... Attachment.

Indian Pink (double)...........Alzorys lovely.

Indian Plum..............Prization.

Iris.................. Irs age.

Iris, German............. F!nme.

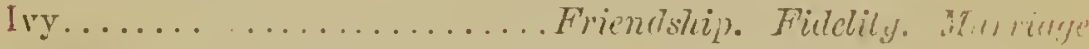
Ivy, Sprig of, with Tendrils....Assiduous to plcase.

JACOB's Ladder............. Come down.

Japan Rose............... Beruty is your only ristruetion.

Japanese Lilies.............. Fou cannot reccive me.

Jasmine ................. Amintility.

Jasmine, Cape............. Trunsport of joy.

Jasmine, Carolina ........... Ecparation.

Jasmine, Indian............. attach mysclf to you.

Jasmine, Spanish............ Siensuality.

Jasmine, Yellow.............. Grace and elegance.

Jonquil................... I desire a return of affertiun.

Judas Tree............... Unbelinf. Ectrayal.

Julienne, White............. Dcspair not; God is evcryzacher.

Juniper................... Siccor. Piotection.

Justicia ................. The perfection of femalelovelincss.

Kennedia................ Mental beauty.

Kingcups ............... Desire of riches.

Labornum................ Forsaken. Pensive beuuty.

Lady's Slipper.............. Capricious beauty. Win mo encis wear me.

Lagerstræmia, Indian ........ Eloquence.

Lantana.................Rigor.

Lapageria Rosea. .......... There is no unalloyed good.

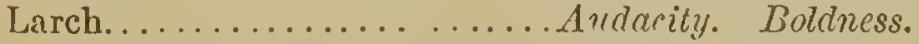

Larkspur..................Lightness. Levity.

Larkspur, Pink.............Ficlileness. 
Larkspur, Purple............ Haughtiness.

Laurel................... Glory.

Laurel, Common, in flower.....Perfily.

Laurel, Ground..............Perseverance.

Laurel, Mountaiu............Ambition.

I.ilurel-leaved Magnolia........Dignity.

Laurestina................ token.

Lavender............... Distrust.

Leaves (dead)................ Kelaneholy.

Lemon.................... Zest.

Lemon Blossoms ............ Fidelity in Love.

Leschenaultia Splendens....... You are eharming.

Lettuce................... Cold-heartedness.

Lichen.................. Dejeetion. Solitude.

Lilac, Field.............. IIumility.

Lilac, Purple.............. First emotions of love.

Lilac, White...............Joy of youth.

Lily, Day................. Coquetry.

Lily, Imperial..............Majesty.

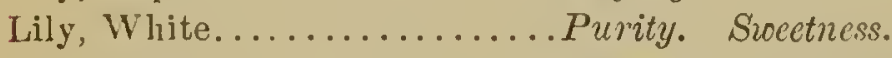

Lily, Yellow................ Fulsehooul. Gay $1 \%$

Lily of the Valley ...........Return of happincss. Uneonscious srocetness.

Linden or Lime Trees......... Conjugal love.

Lint................... I feel my obligations.

Live Oak................. Liberty.

Liverwort................. Conficlenee.

Liquorice, Wild............I deelare against you.

Lobelia..................Afalevolenee.

Locust Tree............... Eleganee.

Locust Tree (green)............Affeetion beyond the grave.

London Pride .............. Frivolity.

Lote Tree................. Concord.

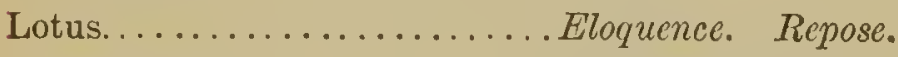

Lotus Flower............... Estranged love.

Lotus Leaf...............Recantation.

Love-in-a-Mist..............Perplexity.

Love-lies-bleeding........... Hopcless, not hectrless.

Lucerne ................. Life.

Lupin................... Voraciousness. 


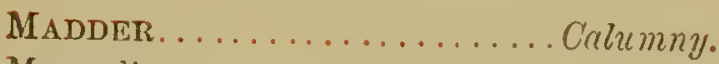

Magnolia............... Love of nature. Magnificence.

Magnolia, Swamp...........Perseverane.

Mallow .................. Mildness.

Mallow, Marsh............Beneficence.

Mallow, Syrian............. Consumed by love.

Mallow, Venetian ............ Delicate beauty.

Malon Creeana ............ Will you share my fortunes?

Manchineal 'Tree............Falsehood.

Mandrake................Horror.

Maple..................Reserve.

Marianthus .............. Hope for better days.

Marigold...............Grief.

Marigold, African.......... Vulgar minds.

IMarigold, French............Jealousy.

Marigold, Prophetic .........Prediction.

Marigold aud Cypress.........Desprit.

Marjoram................ Blushes.

Marvel of Peru............. Timidily.

Meadow Lychnis............ Wit.

Meadow Saffron...........My best clays are past.

Meadowsweet............. Uselessness.

Mercury ................Goodness.

Mesembryanthemum.......... Idlcness.

Mezereon ................ Dcsire to please.

Michaelmas Daisy...........After-thought.

Mignonnette.............. Your qualitics surpass your

Milfoil................. War. charms.

Milkvetch................ Your presence softens my puins.

Milkwort. .

Hermitage.

Mimosa (Sensitive Plant)....... Sensitiveness.

Mint.

Virtue.

Mistletoe................ I surmount difficultics.

Mitraria Coccinea............ Indolence. Dullness.

Mock Orange............... Counterfeit.

Monarda Amplexicaulis....... Your vohims are quite unbearable. Monkshood..............A deadly foe is near.

Monlsshood (Helmet Flower).... Chivalry. Knight-errantry.

Moonwort.................Forgetfulness. 
Morning Glory .............Affectation.

Moschatel............... Wenkness.

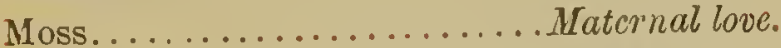

Mosses.................Ennui.

Mossy Saxifrage.............Affection.

Motherwort...............Concealed love.

Mountain Ash.. ...........Prudence.

Mourning Bride........... Unfortunate attachment. I have lost all.

Bouse-eared Chicliweed....... Ingenuous simplicity.

Mouse-eared Scorpion Grass. . . . Forget me not.

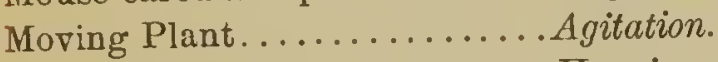

Mudwort................Happiness. Tranquillity.

Mulberry Tree, Black......... I shall not survive you.

Mulberry Tree, White.......Wisdom.

Mushroom................Suspicion; or, I can't entircly trust you.

Musk Plant.............. Weakness.

Mustard Seed..............Indifference.

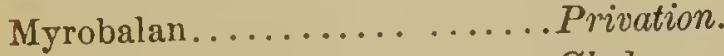

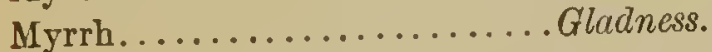

Myrtle................... Love.

NARCISsUS................Egotism.

Nasturtium...............Patriotism.

Nemoplila. .................Success everyzohcre.

Nettle, Common Stinging ...... You ar'e spiteful.

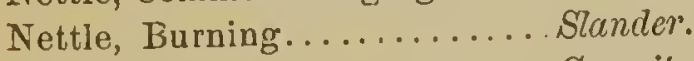

Nettle Tree...............Conceit.

Night-blnoming Cereus ........Transient beauty.

Night Convolvulus ........... Night.

Nightshade............. Falsehood.

OAK Leaves................Bravery.

Oak Tree................ Hospitality.

Oak, White.............. Indepcndence.

Oats.................... The vitching soul of music.

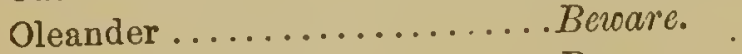

Olive....................Peace.

Orauge Blossoms............ Your purity equals your loveliness, 


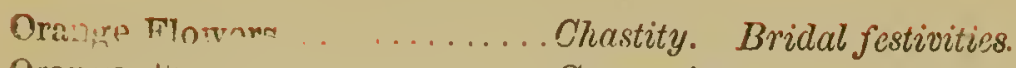

Orauge 1ree..............Generositu.

Orchis...............A belle.

Osier. . ..............Frankness.

Osmunda................ Dreams.

Ox Eye................. Patienee.

Oxlip.................. Speak out.

PALAr. . . . . . . . . . . . Vietory.

Pansy .................. Thought.

Parsley.................Festivity. To win.

Pasque Flower............. You have no claims.

Passion Flower............Religious superstition when the flower is reversed or Faith if ereet.

Patience Dock. ............Patienee.

Pea, Everlasting...........An appointed mecting. Lasting pleasure.

Pea, Sweet. . ............ Departure.

Peach.................. Your qualities, like your charms, are unequaled. Peach Blossom............. I am your captive.

Pear.....................ffeetion.

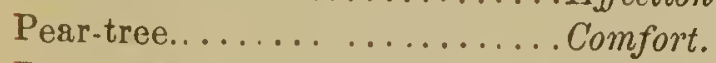

Pentstemon Azureum.........High-bred.

Pennyroyal ............... Flee aroay.

Peolly ................. Shame. Bashfulness.

Peppermint. .............. Warmth of feeling.

Periwinkle, Blue........... Early friendship.

Periwinkle, White. ..........Pleasures of memory.

Persicaria...............Restoration.

Persimmon.................Bury me amid Nature's beruties.

Peruvian Heliotrope ..........Devotion.

Petunia.................. Your presence soothss me.

Pheasant's Eye............Remembrance.

Phlox ................ Unanimity.

Pigeon Berry............. Indifference.

Pimperuel ................Change. Assignation.

Pine.................. Pity.

Pine-apple............... You are perfeet. 
Pine, Pitch ...............Plitlosophy.

Pine, Spruce.... . . . . . . . . Hope in adversu's.

Pink....................Boldness.

Pink, Carnation............. Woman's love.

Pink, Indian Double...........Always lovely.

Pink, Indian Single...........Aversion.

Pink, Mountain ........... Aspiring.

Pink, Red Double.......... Pure and ardent love.

Pink, Single.............. Pure lovc.

Pink, Variegated...........Refusal.

Pink, White.............. Ingeniousness. Talent.

Plantain............... W7ite man's footsteps.

Plane Tree............... Genius.

Plum, Indian.............. Privation.

Plum Tree............... Fidelity.

Plum, Wild............... Independence.

Plumbago Larpenta ......... Holy vishes.

Polyanthus .............. Pride of viehes.

Polyanthus, Crimson ......... The heart's mystery.

Polyanthus, Lilac............ Confidenee.

Pomegranate............. Foolistiness.

Pomegranate Flower.......... Mature eleganec.

Poor Robin ............... Compensation, or an Equivalent.

Poplar, Black............. Courage.

Poplar, White........... Time.

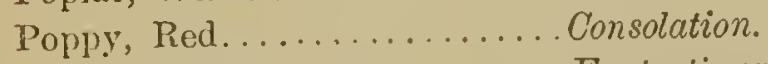

Popny, Scarlet.............. Fantastie extravagance.

Poppy, White............... Sleep. My bane.

Potato ................. Bencvolenee.

Potentilla................. I elaim, at least, your cstcem

Prickly Pear.............. Sative.

Pride of China ............ Dissension.

Primrose................ Early youth and sainess.

Primrose, Evening .......... Ineonstaney.

Primrose, Red............. Unpatronized merit.

Privet................. Prolititition.

Purple Clover... ........... Provident.

Pyrus Japonica.............. Fairies' fire.

QUAKING-Grass.............Agitation. 
Quamoclit.

Queen's Rocket.

\section{Busybody.}

You are the queen of coquettes. Fashion.

Quince. Temptation.

RAGGED-RoBIN.......... Wit.

Ragunculus............. Touare radiant vith charms.

Ranunculus, Garden......... Fou are rich in attractions.

Ranunculus, Wild.......... Ingratitude.

Raspberry .............. Remorse.

Ray Grass .............. Vice.

Rerl Catchtly............. Youthful love.

Reed................... Complaisance. Music.

Reed, Split .............. Indiscrction.

Rhododendron (Rosebay)....... Danger. Beware.

Rhubarb..................Adrice.

Rocket,.................Rivalyy.

Tosa Mundi.............. Variety.

Rose, Austrian............. Thou art all that is lovely.

Rose, Bridal................ Happy love.

Rose, Burgundy............ Unconscious beauty.

Rose, Cablage.............Ambassador of love.

Rose Campion.............. Only deserve my love.

Rose, Caroline............... Love is dangerous.

Rose, China............... Bercuty alrocyss nero.

Rose, Christmas............. Thranquitize my anxiety.

Rose, Daily. .............. Thy smile I uspire to.

Rose, Damask.............. Brilliant complexion.

Rose, Deep Red............Bashful shame.

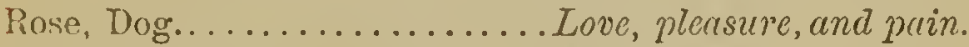

Rose, Guelder...........Winter. Age.

Rose, IInndred-leaved.........Pridle.

Rose, Japan.............. Beruty is your only attraction.

Rose, Maiden-blush. .......... If you love me you vill find it out.

Rose, Montiflora............ Grace.

Rose, Musk.............. Capsicious beauty.

Rose, Musk, Cluster.......... Chrorming.

Rose, Red................ Love.

Rose, Single............. Simplicity.

Rose, Thornless............. Early atturhment. 
Rose, Unique.............. Call me not beautiful.

Rose, White. I am worthy of you.

Rose, White (withered ...... Transient impressions.

Rose, Yellow............... Decrease of love. Jealousy.

Rose, York and Lancaster...... War.

Rose, Full-blown, placed uver

two Buds................ Secrecy.

Rose, White and Red together. . Unity.

Roses, Crown of............. Reward of virtue.

Rosebud, Red................Pure and lovely.

Rosebud, White............. Girlhood.

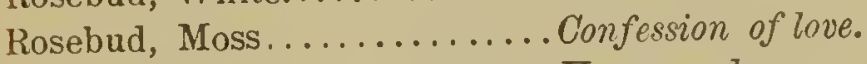

Rose Leaf.................. You may hope.

Rosemary.................Remembrance.

Rudbeckia................Justice.

Rue ................... Disdain.

Rush.................... Docility.

Rye Grass................. Changenble disposition

S.AFFroN.................. Bevare of excess.

Saffron Crocus...............Mirth.

Saffron, Meadow.............My happiest days are past.

Sage ................... Domestic virtue.

Sage, Garden ............. Esteem.

Sainfoin................... Agitation.

Saint John's Wort............Animosity.

Salvia, Blue..............Wisdom.

Salvia, Red...............Energy.

Saxifrage, Mossy............ffection.

Scabious................. Unfortunatc love.

Scabious, Sweet.............Widonchood.

Scarlet Lychnis.............. Sunbeaming eycs.

Schinus..................Religious enthusiasm.

Scotch Fir................Elevation.

Sensitive Plant............. Sensibility.

Senvy .................. Indifference.

Shamrock................ Light-hcartedncss.

Shepherd's Purse............ I offer you my all.

Siphocampylos ............. Resolved to bc noticed.

Suakesfoot................ Horror. 
Snapdragon

Snowball Presumption, also "No.'

Snowdrop. Bound.

Sorrel Hope.

Sorrel, Wild. Affection.

Sorrel, Wood ... Wit ill-timed.

Southernwood. Joy. Spanish Jasmine Jest. Bantering. Spearmint Sensuality.

Speedwell Warmth of sentiment.

Speedwell, Germander........Faeility.

Speed well, Spiked........... Semblanee. Spider Ophrys..............Adroitness.

Spiderwort................ Esteem, not love.

Spiked Willow Herb.........Pretension.

Spindle Tree Your charms are engraven on my heart.

Star of Bethlehem. Purity.

Starwort. After-thought.

Starwort, American Stepbanotis.

Cheerfulness in old age.

St. John's Wort Will you accompany me to the East?

Stock Superstition.

Stock, Ten-week lasting beauty.

Stonecrop. Promptness.

Straw (broken)............. Rupture of a contract.

Straw (whole) Union.

Strawberry Blossoms ......... Foresight.

Strawberry Tree............. Esteem, not love.

Sultan, Lilac. I forgive you.

Sultan, Wlite. Sroeetness.

Sultan, Yellow Contempt.

Sumach, Venice. Splendor.

Sunflower, Dwarf. Adoration.

Sunflower, Tall. Hanghtiness. False riehes.

Swallow-wort. Cure for heartache.

Sweet Basil. Good voishes.

Sweetbrier, American..........Simplicity.

Sweetbrier, Eurupean. I roound to heal. 
Sweetbrier, Yellow.......... Decrease of love.

Sweet Pea................. Delicate pleasures.

Swweet Sultan...............Felicity.

Sweet Sedge...............liesignation.

Sweet.William............Gallantry. Dexterity.

Sycamore................. Curiosity.

Syringa.................. Memory. Fraternal sympathy.

Syriuga, Carolina............ Disappointment.

TAMARISK ................ Crime.

Tansy, Wild ............. I declare war against you.

Teasel................... Misanthropy.

Tendrils of Climbing Plants ... Ties.

Thistle, Common............Austcrity. Independence.

Thistle, Fuller's.............Misanthropy.

Thistle, Scotch........... Retaliation.

Thorn Apple............. Deceitful charms.

Thorn, Branch of............ Scverity.

Thrift................. Sympathy.

Throatwort................ Neglected beauty.

Thyme...................... Activity or Courage.

Tiger Flower...............For once muy pride befriend me.

Traveler's joy............... Safety.

Tree of Life............... Old age.

Trefoil..................Revenge.

Tremella Nestoc.............Resistance.

Trillium Pictum............. Hodest beauty.

Triptilion Spinosum..........Be prudent.

Truffle.................. Surprise.

Trumpet Flower............. Frame.

Tuberose................. Dangerous pleasures.

Tulip, Red................ Declaration of love.

Tulip, Variegated ........... Beautiful eyes.

rulip, Yellow............... Hopeless love.

Tulip........................ Charity.

Tussilage, Sweet-icented...... Justice shall be done you.

VALERIAN ...............An accommodating disposition.

Talerian, Greek ... . . Rupture.

"enice Sumach............. Intellectual excellence. Splendor. 
Venus's Car. ..............Fly with me.

Venus's Looking glass.........Fiattery.

Veıus's Trap...............Deceit.

Verhena, Pink.............. Fumily ^nion.

Verbena, Grarlet........... Unite against evil; : Church unity.

Verbena, White.............Pray for me.

Vernal Grass................Poor, but happy.

veronica. ............... Fidclity.

veronica Speciosia ... ...... Keep this for my salict.

Vervain. ............... Enchantment.

Vine................ Intoxication.

Violet, Blue............... Faithfulness.

Violet, Dame... . ........Wathlifulness.

Violet, Sweet..............Modesty.

Vislet, Yellow. ............Rurul happiness.

Virginia Creeper............ cling to you ioth in sunshine anci stade.

Virgin's Bower............. Filial love.

Viscaria Oculata............. Will you dance woith me?

Volkamenia................ May you be happy.

WALI.ELOWER. ............ Fiddelity in adversity.

Walnut................ intellect. Stratrgem.

Watcher by the Wayside...... Never despair.

Water-Lily . .............. Purity of heart.

Water-Melon............... Bulkiness.

Wax-Plant.

Susceptibility.

Wheat Stalk............. Riches.

Whin....................

White Flytrap........... Deceit.

White Jasmine. .......... Amiableness.

Whice Lilv ... ........ Purity and modesty.

White Muilein ... ...Good nature.

White Oak.............. Independence.

White Pink. ........... Talent.

White Poplar.......... Time.

White Rose (dried)......... Deuth preferalle to lns of inno. cence

Whortleberry.............. Treason. 
Willow, Creeping.............Love forsaken.

Willow, French............. Bravery and humanity.

Willow Herb...............Pretension.

Willow, Water.............Freedom.

Willow, Weeping............Mourning.

Winter Cherry............ Deception.

Wisteria................. Welcome, fair stranger.

Witch IIazel..............A spell.

Voodbine ................ Fraternal love.

ivood Sorrel...............Joy. Maternal tenderness.

Wormwood.................Absence.

Yanthium.................Rudeness Pertinacity.

Seranthemum..............Cheerfulness under adversity.

YEW....................... Sorrow.

TrenYR Flower..............Epectation.

Limnia................. Thoughts of absent friends.

\section{PART THE SECOND.}

A BSENCE ................. Wormroood.

Abuse not................. Crocus.

Acknowledgment...........Canterbury Bell.

Activity or Cournge...........Thyme.

A deadly foe is near..........Monkshood.

Aduniration ................ Amethyst.

Adoration.. .............. Droarf Sunflower.

Adroitness.................. Spider Ophlıys.

Adulation................ Cacalla.

Advice...................Rhubarb

Affection............... Mossy Samfrage

tffection................. Pear

affection................ Sorrel

dffection beyond the grave .... Areen Locust. 
Affection, Maternal.......... Cinquefoil.

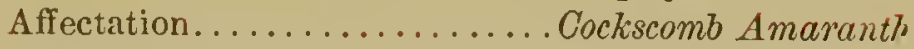

Affectation.................Morning Glory.

Affliction................... Black Poplar:

After-thought..............Michaelmas Daisy.

After-thought............. Starwort.

After-thonght.............. China Aster.

Agreement................ Strazo.

Age..................... Guelder Rose.

Agitation................Moving Plant.

Agitation ...........................

Alas! for my poor heart....... Deep Red Carnation.

Always cheerful,........... Coreopsis.

Always delightful........... Cineraric.

Always loveiy............... Indian Pink (double).

Ambassador of Love.......... Cabbage Riose.

Amiability................Jasmine.

Anger.................. Whin.

Anger ................... Furze.

Animosity................... John's Wort.

Auticipation..............Gooseberry.

Anxious and trembling.........Red Columbine.

Ardor, Zeal................Cuckoo Point. Arum.

Argument. ...............Fig.

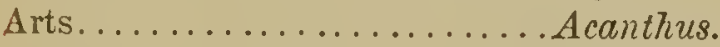

Artifice.................. Clematis.

Assiduous to please.......... Sprig of ivy, with lrits.

Assignation............... Pimpernel.

Attachment.............. Indiun Jasmine.

Audacity.................. Larch.

Avarice ................. Scarlet Auriculct.

Aversion .................Chinese or Indirin Pink.

BANTERING................. Southernwoood.

Baseness................. Dodder.

Bashfulness.............. Peony.

Bashful shame.............. Dcep Red Rose.

Be prudent.............. Triptilion Spinosum.

Be warned in time............ Echites Atropurpurca.

Beautiful ejes.............. Variegated Tulip. 
Beauty................. Parti-colored Drisy.

Beauty always new.......... China Rose.

Beauty, Capricious...........Lady's Slipper.

Beauty, Capricious............. Musk Rose.

Beauty, Delicate. ........... Flower of an hour.

Beauty, Delicate..............Hibiscus.

Beauty, Divine ............. American Corsslip.

Beauty, Glorious ............Glory-flower.

Beauty, Lasting............ Stock.

Beauty, Magnificent..........Calla Atriopica.

Beauty, Mental............... Ulematis.

Beauty, Modest............. Trillium Pictum.

Beauty, Neglected............ Throutioort.

Beauty, Pensive.............Laburnum.

Beauty, Rustic.............. French Honeysuckle.

Beauty, Unconscious.......... Burgundy Rose.

Beauty is your only attraction. . Japan Rose.

Belle..................... Orchis.

Be mine.................. Four-leaved Clover.

Beneficence................ Mrarshmailozo.

Benevalence.............. Potato.

Betrayed .............. White Catchfly.

Beware.................. Oleander.

Beware............... Rosebay.

Beware of a false friend........ Francisca Latifolia.

Bitterness ................Aloe.

Blackness ............... Ebony Tree.

Bluntness... . ............. Borage.

Blushes .................. Marjoram.

Boaster................ Hydrangea.

Boldness................ Pink.

Bonds................... Convolvulus.

Bonds of affection. . . ....... Gillyflower.

Bravery................. Onk Leaves.

Brarery and humanity. ....... French Willow.

Bridal favor................. Toy Geranium.

Brilliant complexion.......... Damask Rose.

Bulk...................Water-Melon.

Bulk.................... Gourd.

Busybody................ Qucemoclit. 
Bury me amid nature's beauties.Persimmon.

Call me not beautiful........ Rose Unique.

Calm repose...............Buckibean.

Calumny................. Hellcbore.

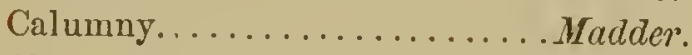

Change.................. Pimpernel.

Changeable disposition........ Rye Grass.

Charity................ Turnip.

Charming................. Cluster of Musk Roses.

Charms, Deceitful........... Thorm Apple.

Cheerfulness.............. Saffron Crocus.

Cheerfulness in old age.......American Starwoort.

Cheerfulness under adversity. . Chincse Chrysanthemum

Chivalry.................Monkshood.

Cleanliness................ Hyssop.

Cold-heartedness ............ Lettuce.

Coldness................... Agnus Castus.

Color of my life............ Coral Honeysuckle.

Come down................. Jacob's Ladder.

Comfort................. Pear Tree.

Comforting................ Scarlet Geranium.

Compassion................. Allspice.

Concealed love.............Mothervort.

Concert..................... Tettle Tree.

Concord................ Lote Tree.

Confession of love............. Moss Rosebud.

Confidence................ Mepatica.

Confidence................ Lilac Polyanthus.

Confidence................ Liverwoort.

Confidence in Heaven......... Flowering Reed.

Conjugal lore .............. Time or Linden Tree.

Consolation ...............Red Poppy.

Constancy................ Bluebell.

Consumed by love........... Syrian Malloro.

Contentment ..............Hoyabella.

Could you bear poverty ?...... Browallia Jamisonii.

Counterfeit................Mock Orange.

Courage .................. Black Poplar.

Crime ................. Tamurisk. 
Cure....................Bulm of Gilead.

Cure for heartache............ Srcallow-20ort.

Curiosity..................Syeamore.

DANGER.................Rhododendron. Rosebay.

Dangerous pleasures..........Tuberose.

Death ................... Cypress.

Death preferable to loss of innocence..................Whitc Rose (dried).

Deceit................. Apocynum.

Deceit................... White Flytrap.

Deceit.................. Dogsbane.

Deceit.................... Gcranium.

Deceitful charms............ Ithorn Apple.

Deception................ White Cherry Tres.

Declaration of love...........Red Tulip.

Decrease of love............ Tellow Rose.

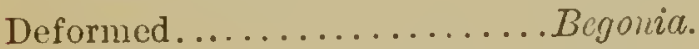

Dejection.................. Lichen.

Delay................... Eupatorium.

Delicacy.. ...............Blucbottle. Centaury.

Delicacy................ Cornflower.

Depart................. Dandelion Seeds in the ball.

Desire to please..............Mczcreon.

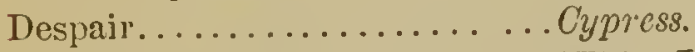

Despair not, God is everywhere. White Julienne.

Despondency.............. Humble Plant.

Devotion, or, I turn to thee....Peruvian Ifcliotrope.

Dexterity.................. Sweet-William.

Difficulty................Blackthorn.

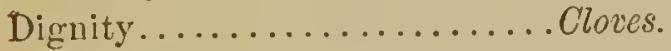

Dignity.................Laurel-leaved Magnolia.

Disappointment............ Carolina Syringa.

Disdain................. Yellozo Carnation.

Disdain...$\ldots \ldots \ldots \ldots \ldots$. Rue.

Disgust................. Frog Ophrys.

Dissension ............... Pride of China.

Distinetion.................... Cardinal Flower.

Distrust ................. Lavender.

Divine beauty.............American Coroslip. 
Docility................Rush.

Domestic industry ..........Flax.

Domestic virtue............. Sage.

Do not despise my porerty...... Shepherd's Purse.

Do not refuse me............ Eschscholtzia, or Carrot Fluw.r.

Doubt ...................Apricot Blossom.

Durability ............... Dogroood.

Duration................... Cornel Tree.

EARLY attachment.......... Thornless liose.

Early friendship........... Blue Perizoinkle.

Early youth..............Primrose.

Elegance.................. Loeust Tree.

Elegance and grace. ......... Yelloro Jasmine.

Elevation................. Seoteh Fir.

Eloquence.............. Lagerstrcemir, Indian.

Enchantment...............Holly Herb.

Euchantment.............. Vervain.

Energy.................. Red Salvia.

Energy in adversity.......... Camomile.

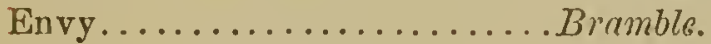

Error...................... Bee Orchis.

Error..................Fly Orchis.

Esteem.................Garden Sage.

Esteem, not love .......... Spiderwort.

Esteem, not love............. Strecuderry 7ree.

Estranged love............. Lotus Flower.

Excellence................ Crimellia Japonica.

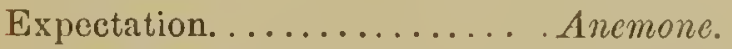

Expectation................. Zephyr Flower.

Expected meeting............ Nutmeg Geranium.

Extent. ................... Gourd.

Extinguished hopes.......... Convolvulus Major.

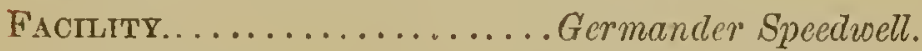

Fairies' fire.................Pyrus Juponiea.

Faithfulness ............... Blue Violet.

Faithfulness.............lltiotrope.

Falsehood................ Bugloss. Deadly Nightshade.

Falsehood................. Yellowo Lily. 
Falsehood................Manchincul Tree.

False riches............... Tall Sunflower.

Fame................. Tulip.

Fame speaks him great and good Apple Blossom.

Family union...............Pink Verbena.

Fantastic extravagance ........ Scarlet Poppy.

Farewell...............Michaelmas Daisy.

Fascination ..............Fern.

Fascination ............... Honesty.

Fashion.................. Quecn's Rocket.

Fecundity................ Hollyhock.

Felicity.................. Sweet Sultan.

Female fidelity.............. Spcedwell.

Festivity.................. Parsley.

Fickleness ................ Abatina.

Fickleness . . . . . . . . . . . Pink Larkspur.

Filial love.............. Virgin's-bower.

Fidelity................. Veronica. Ivy.

Fidelity..................Plum Tree.

Fidelity in adversity..........Wallflower.

Fidelity in love............. Lemon Blossoms.

Fire...................Flcur.de-Luce.

First emotions of love.........Purple Lilac.

Flame................. Flleur-de-lis. Iris.

Flattery .................. Venus's Looking-glass.

Flee away........................

Fly with me............... Venus's Car.

Folly................... Columbine.

Foppery ................Cockscomb. Amaranth.

Foolishness .............. Pomegranate.

Foresight................Holly.

Forgetfulness ..............Mroonwort.

Forget ne not............. Forget-me-not.

For once may pride befriend me. Tiger Fincer.

Forsaken ................ Garden Anemone.

Forsaken.................Laburnum.

Fortitude................Dipteracanthus spectabilis.

Fragrance.............. Camphire.

Frankness .............. Osicr.

Fratcinal love.............Woodbine. 
Fraternal sympathy.......... Sypinga.

Freedom.................Water Willon.

Freshness. .............. Damask Rose.

Friendship................ Acacia. Iry.

Friendship, carly........... Blue Perinoinkle.

Friendship, trum. ........... Oak-lecuved Geranium.

Friendship, unchanging........Arbor Vito.

Frivolity................. London Pride.

Frugality.................. Chieory. Endive.

GayeTr.................Butterfly Orehis

Gayety................. Yollow Lily.

Gallantry................. Srcect-William.

Generosity............... Orange Trec.

Generous and devoted affection. Frencil Lioneysuckle.

Genius...................Plane Tree.

Gentility................. Corn Cockile.

Girlhood. ............... Thitite Roscbud.

Give me your good wis he's . . . Swocet Basil.

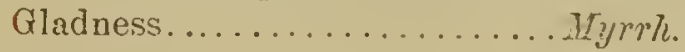

Glory.................. Laurel.

Glory. Immortalit.......... Dophne.

Glorious beauty ............. Glory Flower.

Goodness..................Bonus Henricus.

Goodness ..................Mereury.

Good education. ............. Cherry Tree.

Good wishes ............... Siceet Busit.

Good-nature............... White Mullein.

Gossip................... Cobcea.

Grace................................. Reltora Rose.

Grace and elegance........... Yclloro Jasmine.

Grandeur.................Ash Tree.

Gratitude................ Small White Bellflower.

Grief.....................Harebell.

Grief..................... Marigold.

IIAPPy love............... Bridal rose.

Hatred. . ................Basil.

Haughtiness .............. Purple Larkspur.

Haughtiness.............. Tall Sunflower. 


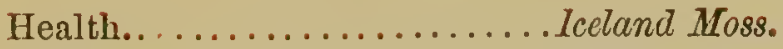

Hermitage.................Miltivoort.

Hidden worth ............Coriander.

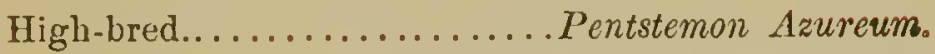

Holy wishes. ............... Plumbago Larpenta.

Honesty ................. Honesty.

Hope..................Flowering Almond.

Hope...................Hanthorn.

Hope.................... Snowdrop.

Hope in adversity ............Spruce Pine.

Hopeless love............... Yellow Tulip.

Hopeless, not heartless......... Love-lies-bleeding.

Horror...................Mandrake.

Horror.................. Dragonswort.

Horror.................. Snakesfoot.

Hospitality................ Oak Tree.

Humility................Broom.

Humility ................ Smaller Bindroeed.

Humility................ Field Lilac.

I AM too happy............. Cape Jasmine.

I am your captive............Peach Blossom.

I am worthy of you.......... White Rose.

I change but in death......... Bay Leaf.

I claim at least your esteem.... Potentilla.

I dare not.................. Veronica Speciosa.

I declare against you.......... Belvedere.

I declare against you........... Liquorice.

I declare war against you...... Wild Tansy.

I die if neglected............. Laurestina.

I desire a return of affection.... Jonquil.

I feel my obligations.......... Lint.

I feel your kindness............ Flax.

I have lost all.............. Mourning Bride.

I live for thee.............. Cedar Leaf.

I love....................Red Chrysanthemum.

I offer you my all.............. Shepherd's Purse,

I offer you my fortune, or I offer you pecuniary aid........... Calceolaria.

I share your sentiments....... . Double China Aster. 
I share your sentiments....... Garden Daisy.

I shall die to-morrow. . ........Gum Cistus.

I shall not survive you. . . . . . . Black Mulberry.

I surmount difliculties.......... Mistletoe.

I watch orer you............Mountain Ash.

I weep for you ............Purple Verbena.

I will think of it ........... Single China Aster.

I will think of it, or liope...... Illild Daisy.

I wound to heal............... Eglantine. Sweetbrier.

If you love me, you will find it out................. Maiden Blush Rose.

Idleness.................. Mesembryanthemum.

Ill-nature.............. Crab Blossom.

Ill-natured beauty........... Citron.

Imagination. ............. Lupine.

Immortality................ Globe Amaranth.

Impatience................ Yellow Balsam.

Impatient of absence..........Corchorus.

Impatient resolves. .........Red Balsam.

Imperfection............. Henbane.

Importunity................Burdock.

Inconstancy................Evening Primrose.

Incorruptible...............Cedar of Lebanon.

Independence.............Common Thistle.

Independence................ Wild Plum Tree.

Independence..............White Oak.

Indifference................ Ever-flowering Candytuft.

Indifference...............Mustard Seed.

Indifference............... Pigeon Berry.

Indifference............... Senvy.

Indiscretion................ Split Reed.

Indolence.................. Mittraria Coccinea.

Industry. ..............Red Clover.

Industry, Domestic......... Flax.

Ingeniousness............. White Pink.

Ingenuity ..............Penciled Geranium.

Ingenuous simplicity...........Mouse-eared Chickroeed.

Ingratitude.............. Oronofoot.

Innocence............... Duisy.

Insincerity............... Foxglove. 
Insinuation ..............Great Bindweed.

Inspiration $\ldots \ldots \ldots \ldots \ldots$ Angeliea.

Instability............. Dutilia.

Intellect............... Walaut.

Intoxication............. Tine.

Irony ................ Sardony.

JEALOUSY.................. French Marigold.

Jealousy................ Yellow Ruse.

Jest..................... Southernwood.

Joy.................... Itvod Sor'vel.

Joys to come. .............. Lesser Celandine.

Justice................. Rulbeckia.

Justice shall be done to you .... Coltsfoot, or Succt-scented Tussilage.

KEEP your promise..........Pciunia.

Kindness................. Seurlet Geranium.

Knight-errantry............ Melmet Flower (Monkshood):

Lamentation ..............Aspen Tree.

Lasting beauty ........... Stock.

Lasting pleasures.... .......Evertasting Pea.

Let me go................Butterfly Weed.

Levity.................. Larkspur.

Liberty................. Live Oak.

Life.................... Luecrne.

Light-heartedness........... Shamrock.

Lightness.............. Larkspur.

Live for me............... Arbor Vitce.

Love................... Mryrtle.

Lore.................... Rose.

Love, forsaken.............. Creeping Willow.

Love, returned.............Ambrosia.

Love is dangerous.......... Carolina Rose.

Love for all seasons .......... Furze.

Luster................... Acnnite-leaved Cronfoot, or Fair Maid of France.

Luxury.................. Chestnut Tree. 
MAaNiFicenCE Magnolin.

Magnificent beauty..........Calla Attriopica.

Majesty..................Crown Imperial.

Make baste..............Dianthus.

Malevolence..............Lobelia.

Marriage................ Ivy.

Maternal affection.......... Cinquefoil.

Maternal love.............Moss.

Materual tenderness.......... Wood Sorrel.

Matrimony ............. American Linden.

Matronly grace............. Crattleya.

Mature charms............. Cattleyn Pineli.

May you be happy............ Volkamenia.

Meanness................ Cuscuta.

Meekness............... Bireh.

Melancholy...............Autumnai Teaves.

Melancholy................Dark Geranium.

II. incholy ............... Dead Leaves.

Mental beauty............... Clematis.

Muntal beauty.............. Kennedia.

Message................. Iris.

Mildness................Mallow.

Mirth .................. Saffron Crocus.

Misanthropy............... Alite (Wolfsbane).

Misauthropy... ............. Fuller's T'eazle.

Modest beauty.............. Trillium Pictum.

Modest genius.............. Creeping Cereus.

Modesty................. Violet.

Modesty and purity.......... White Lily.

Momentary happiness......... Virginian Spiderwort.

Mourning................. Weeping Willow.

Music...................Bundles of Reed woith their Ponicles.

My best days are past......... Colehicum, or Meadono Suffion.

My regrets follow you to the grave.................. Asphodel.

Neatness............. Bruom.

iveglected beauty. ....... . Thronaticort.

Siever-ceasng remembrance . . Eivert!sting. 
Never despair............. Watcher by the Wryside.

No.....................Snapdragon.

OLD age................ Tiree of tife.

Only deserve my love.........Rose Campion.

PAINFUL recollections..........Flos Adonis.

Painting................Auricula.

Painting the lily............. Daphne Odora.

Passion................... White Dittany.

Paternal error...............Cardamine.

Patience..................Dock: Ox-eye.

Patriotism................American EZm.

Patriotism.................Nasturtium.

Peace.................... Olive.

Perfected loveliness........... White Camellia Japonica.

Perfidy .................. Common Laurel, in flower.

Pensive beauty.............Laburnum.

Perplexity................. Love-in- - - Mrist.

Persecution...............Checkered Fritillary.

Perseverance.............. Suamp Magnoliu.

Persuasion.................Althea Frutex.

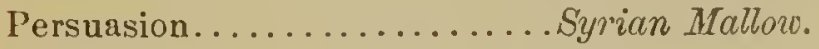

Pertinacity................. Clotbur.

Pity.................. Pine, also Andromeda.

Pleasure and pain...........Dog Rose.

Pleasure, lasting............Everlasting Pcr.

Pleasures of memory......... White Periuintile.

Pomp................... Dahlia.

Popular favor............... Cistus, or Rock Rose.

Poverty.................Evergreen Clematis.

Power.................. Imperial Montague.

Power....................Cress.

Pray for me.............. White Verbena.

Precaution................. Golden Rod.

Prediction................... Prophetic Marigold.

Pretension.................Spiked Willow II I rb.

Pride....................Hundred-leaved Rose.

Pride .................. Amaryllis.

Privation................ Indian Plum. 


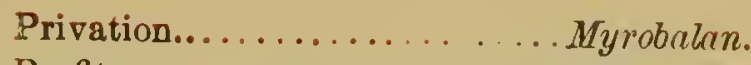

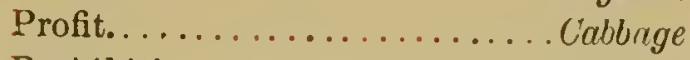

Prohibition................ Privet.

Prolific................... Fig Tree.

Promptness............... T'en-week Stock.

Prosperity.................Beech Tree.

Protection.................Bearded Crepis.

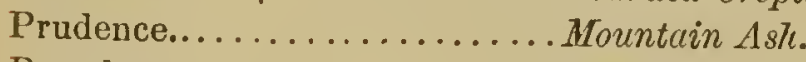

Pure love................. Single Red Pink.

Pure and ardent love.......... Double Red Pink.

Pure and lovely..............Red Rosebud.

Purity................... Star of Bethlehem.

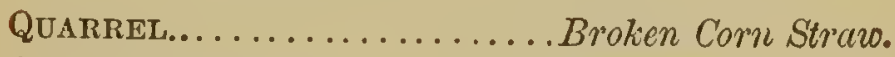

Quicksightedness.............Hawkweed.

REAdY-ARMED...............Gladioli.

Reason................... Goat's Rue.

Recantation............... Lotus Leaf.

Recall................... Sitver-lenved Geranium.

Reconciliation............ Fillbert.

Reconciliation..............Hazel.

Refinement................ Gardenia.

Refusal................. Striped Carnation.

Regard.................. Daffodil.

Regret.................. Purple Verbena.

Relief.................Balm of Gilead.

Relieve my anxiety..........Christmas Iiose.

Religious superstition.........Aloe.

Religious superstition, or Fait!l. Passion Flower.

Religious enthusiasm..........Schinus.

Remembrance............ Rosemary.

Remorse................Bramble.

Remorse................. Raspberry.

Rendezvous................ Chickroeed.

Reserve................. Maple.

Resistance.............. Tremilla Nestoc.

Resolved to be noticed.........Siphocampylos.

Restoration...............Persicaria.

Retaliation.................Scotch T'histie. 
Return of happiness.......... Lity of the Valley. Revenge.................. Birdsfoot Trefoil.

Reverie..................Flowering Fern.

Reward of merit............Bay Wreath.

Reward of virtue........... Garland of Roses.

Riches................... Corn.

Riches..................Buttereups.

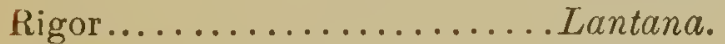

Rivalry................. Rocket.

Rudeness......................tbur.

Rudeness................Xanthium.

Rural happiness............ Yellow Violet.

Rustic beauty. .............. Freneh IIoneysuekle.

Rustic oracle.............Dandelion.

SaDNESS.................. Dead Leaves.

Safety....................Traveler's Joy.

Satire..................Prickly Pear.

Sculpture................ Iloya.

Secret love............... Yellow Aeacir.

Semblance............... spiked Spectiv" "?

Sensitiveness. ..............Mimosa.

Sensuality ..............Spanish Jasmi.

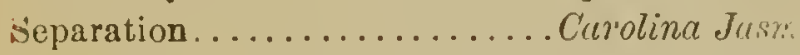

Severity................Braneh of Tho

shame.................. Peony.

Sharpness................Barberry Tree.

Sickness ................. Anemone (Zephyr Fluncr $)$.

Silent love............... Evening Primrose.

Sillicess ................Fool's Parsley.

Simplicity................ Ameriean Sicectbrie?.

Sincerity.................Garden Chervil.

Slighted love............. Yellow Chrysanthemum.

Snare......................... Dragon Plant.

Solitude................ Ileath.

Soon...................Blackthorn.

Sorrow................ Yew.

Sourness of temper...........Barberry.

Speak -ut................ Oxlip.

Speli...................... Cirear. 
Spleen .................. Fumitory.

Splendid beauty ............ Amaryllis.

Splendor..................Yellow A uricula.

Sporting................. Fox tail Grass.

Steadfast piety.............. Wild Geranium.

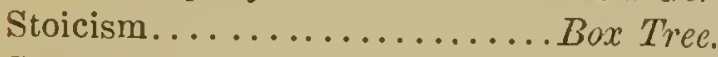

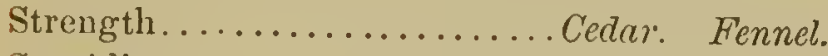

Stupidity ................Horseshoe-leaf Geranium.

Submission............... Grass.

Submission................ Harebell.

Success everywhere.......... Nemophila.

Success crown your wishes..... Coronella.

Succor.................. Juniper.

Such worth is rare............Achimenes.

Sun-beaming eyes........... Scarlet Lychnis.

Superstition................. St. John's Wort.

Surprise.. .............. Thuffle.

Susceptibility.............Wax Plant.

Suspicion................ Champignon.

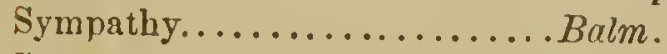

Sympathy.............. Thrift.

Talent................... White Pink.

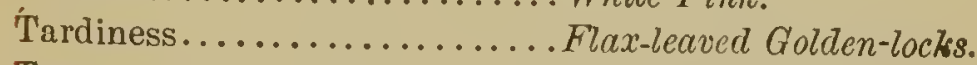

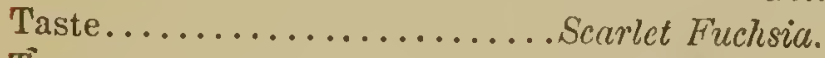

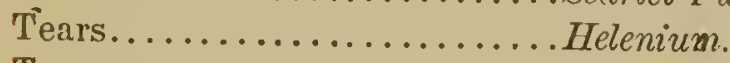

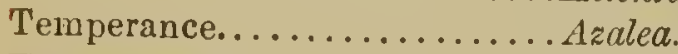

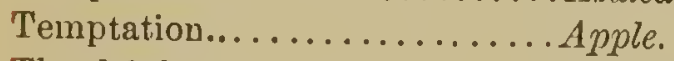

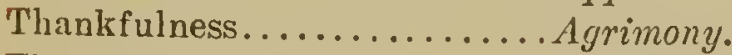

The color of my fate.......... Coral Honeysuckle.

The heart's mystery.......... Crimson Polyanthus.

The perfection of female loveli-

ness.................. Justicia.

The witching soul of music.... Oats.

The variety of your cunversation

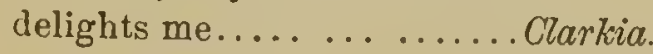

Thee only do I love...........Arbutus.

There is no unalloyed good..... Lapagenia Rosea.

Thoughts .............. Pursy.

Thoughts of absent friends... Zinnia. 
Thy frown will kill me ...... Currant.

Thy smile I aspire to....... . Daily Rose.

Ties.................... Tendrils of Climbing Plants.

Timidity.................. Amaryllis.

Timidity................. Marvel of Peru.

Time................... White Poplar.

Tranquillity ...............Mudvort.

Tranquillity............... Stonecrop

Tranquilize my auxiety........ Uhristmas Rose.

Transient veauty .... ........ Night-blooming Cereus.

Transient impressions......... Withered White Rose.

Transport of jor . ......... Cape Jirmine.

Treachery .................. Bilberry.

True love................. Forget-me.not.

True friendship.............. Oak-leaved Geranium.

Truth ...................Bittersweet Nightshade.

Truth. ................. White Chrysanthemum.

UNANIMITY...............Phlox.

Unbelief ...............Judas Tree.

Unceasing rememhrance... ...American Cudweed.

Unchanging friendship........Arbor Vitc.

Unconscious beauty...........Burgundy Rose.

Unexpected meeting.......... Lemon Geranium.

Unfortunate attachment.......Mourning Bride.

Unfortunate love........... Scabious.

Union.................. Whole Straw.

Unity................... White and Red Rose together.

.Unite against a common foe... Scarlet Verbena.

Unpatronized merit .......... Red Primrose.

Unrequited love............ Daffodil.

Uprightness............... Imbricata.

Uselessness.................Meadorosweet.

Utility................. Grass.

VARIETY................... Ciina Aster.

Variety..................Rosa Mundi.

Vice................... Darnel (Ray Grass).

Victory............... Palm.

Virtue..................Mint. 
Virtue, Domestic............. Sage.

Volubility................Abecedary.

Voraciousness.................upine.

Vulgar minds............... Africun Marigold.

War.................... Fork and Lancraster Rose.

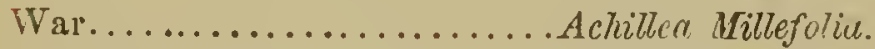

Warlike trophy............ Indiun Chess.

Warmth of feeling...........Peppermint.

Watchfulness.............. l)ame Violet.

Weakness.................Moschatel.

Weakness...............Musk Plant.

Welcome, fair stranger........Wisteria.

Welcome to a stranger.........American Starroort.

Widowhood................. Srceet Scabious.

Will you accompany me to the

East ?................ Stephanotis.

Will you dance with me?..... Viscaric Oculata.

Win me and wear me.........Lady's Slipper.

Winning grace............... Covestip.

Winter...................Guelder Rose.

Wisdom..................Blue Salvia.

Wit .................... Meadow Lychnis.

Wit, ill-timed.............. Wild Sorrel.

Witcheraft................Enchanter's Nightshade.

Worth beyond beauty ........ Sweet Alyssum.

Worth sustained by judicious

and tender affection........ Pink ('onvolvulus.

Worldliness, self-seeking...... Clianthus.

Worthy of all praise.......... Fennel.

Fou are cold............. Hortensix.

You are my divinity..........American Cowoslip.

You are perfect............ Pineapp!

You are radiant with charms Ranunculus.

You are rich in attraction..... Grerden Ranunculus.

You are the queen of coquettes.Queen's Rocket.

You are charming........... Leschenaultia splendens.

Inu have no claims........... Pasque Hlower.

You have many lovers......... Chorozema Varium. 
You please all.............. Branch of Currants.

You are too bold............. Dipladenic Crussinoaa.

You will be my death..........Hemlock.

Your charms are engraven on my heart................ Spindle Tree.

Your looks freeze me.......... Ice Plant.

Your presence softens my pain. Afilkvctch.

Your purity equals your loveliness................. Orange Blossoms.

Your qualities, like your charms, are unequaled............. Peach.

Your qualities surpass your

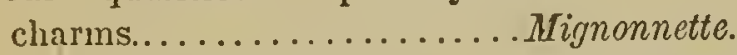

Your temper is too hasty...... Grammanthes Chloraflora.

Youthful beauty............. Covoslip.

Youthful innocence........... White Lilac.

Youthful love...............Red Catchfly

Your whims are unbearable.... Monurdu $A$ mplexicaulis.

ZEAlousness................ Elder.

Zest.....................Lemon. 
The aetry of delocers. 



\section{TII POETRY OF FLOWRRS.}

\section{Enamer.}

KTenss

TVER let the faney roam,

Pleasure never is at home;

At a touch sweet pleasure melteth

Like to bubble, when rain pelteth.

Then let winged Faney wander

Through the thought still spreal beyond ber.

Open wide the mind's eage door,

She'll dart forth, and clouáward soar.

Oh, sreet Faney! let her loose,

Summer's joys are spoilt by use,

And the enjoying of the spring

Fades as does its blossoming:

Autumn's red-lipped fruitage ton,

Blushing through the mist and dew, 
Cloys with tasting: what do then?

Sit thee by the ingle, when

The sear faggot blazes bright,

Spirit of a winter's night ;

When the soundless earth is muffled,

And the caked snow is shuffled

From the ploughboy's heavy shoon:

When the Night doth meet the Moon

In a dark eonspiracy

To banish Even from her sky.

Sit thee here, and send abroad,

With a mind self-overawed,

Faney, high-eommissioned;-send her!

She has vassals to attend her;

She will bring, in spite of post,

Beauties that the earth hath lost;

She will bring thee, all together,

All delights of summer weather;

All the buds and bells of May,

From dewy sward or thorny spray,

All the heaped Autumn's wealth,

With a still, mysterious stealth:

She will mix these pleasures up

Like three fit wines in a eup,

And thou shalt quaff it; thou shalt liess

Distant harvest-earols elear;

Rustle of the reaped eorn;

Sweet birds antheming the morn;

And, in the same moment, hark! 
'Tis the early April lark,

Or the rooks, with busy eaw,

Foraging for stieks and straw.

Thou shalt, at one glanee behold,

The daisy and the marigold;

White-plumed lilies, and the first

Hedge-grown primrose that hath burst;

Hilicded hyacinth, aIwaj

Sapphire queen of the mid-May;

And every leaf, and every flower

Pearled with the self-same shower.

Thou shalt see the field-mouse creep

Meager from its eelled sleep;

And the snake all winter-thin

Cast on sunny bank its skin;

Freekled nest-eggs thou shalt see

Hatching in the hawthorn-tree,

When the hen-bird's wing doth rest

Quiet on her mossy nest;

Then the hurry and alarm

When the bee-hive easts its swarn;

Aeorus ripe down-pattering,

While the Autumn breezes sing. 


\section{Tourember.}

\section{Bryaut.}

VET one smile more, departing, distant sun I

I One mellow smile through the soft vapory air, Ere, o'er the frozen earth, the loud winds run, Or snows are sifted o'er the meadows bare; One smile on the brown bills and naked trees, And the dark roeks whose Summer wreaths are cast, And the blue Gentian flower, that, in the breeze, Nods lonely, of her beauteous raee the last. Yet a few sunny rays, in which the bee Shall murmur by the hedge that skirts the way, The erieket ehirp upon the russet lea, And man delignt to linger in thy ray. let one rich smile, and we will try to bear The piereing Winter frost, and winds, and darkenced air 


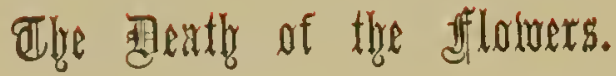

C. Bowles

IOW happily, how happily the flowers die away!

1 Oh, could we but return to earth as easily as they! Just live a life of sunshine, of innocence and bloom,

Then droop, without decrepitude or pain, into the tomb.

The gay and glorious creatures! they neither toil nor spin Yet, lo! what goodly raiment they're all apparell'd in! No tears are on their beauty, but dewy gems more bright Than even brow of Eastern Queen, endiadem'd with light.

The young rejoicing creatures! their pleasures never fall, Nor lose in sweet contentment, because so free to all; The dew, the shower, the sunshine, the bahny blessed air, Spend nothing of their fresheness, though all may freely share.

The happy, careless creatures! of Time they take no heed: Nor weary at his creeping, nor tremble at his speed; Nor sigh with sisk impatience, or wish the light away, Aud when 'tis gone, ery dolefully, would God that it were day ! 
And when their lives are over; they droop away to rest, Uneonscious of the penal doom, on holy Nature's breast, No pain have they in dying; no shrinking from decay Oh! could we but return to earth as casily as they!

\section{ataredoell to the fiflowers.}

Mrs. L. H. sigoumey

GO to your peaeeful rest,

Friends of a brighter hour,

Jewels on youthful Beauty's breast.

Jights of the hall and bower!

Well have ye done your part

Fair children of the sky,

We'll keep your memory in our heart.

When low in dust ye lie.

Yuur gladness in our joy,

Your smile beside our way,

Your gentle serviee round the bed,

Of siekness and decay;

Your rainbow on the elouds,

Your sympathy in pain.

We'll keep the memory of your deeds

Until we meet agan. 
FAREWELL TO THE FLOWERS.

Rest - from the blush of love, -

Rest-from the blight of eare,

From the sweet nursing of your buds.

And from the nipping air.

Rest-from the fever-thirst

Of Summer's noontide heat.

From coiling worm, and rifling hand,

That vexed your lone retreat.

If e'er ye thrill'd with pride,

When the admirer knelt

Or on the lowly look'd with scorn.

Which man for man hath felt,

If through your bosom pure,

Hath aught like evil flow'd,

(Sinee folly may with angels dweli.)

Rest from that painful load.

But not with grief or fear,

Bow down the drooping head,

See-in the ehamber of your birtb;

Your dying eouel is spread.

Go, strong in faith, ye flowers,

Strong in your guileless trust,

With the returning birds to rise

Above imprisoning dust. 
Hear we a whisper low.

From withering leaf and bell?

"Our life hath been a dream of lovo

In garden or in dell!

Yet wintry sleep we hail,

And till the trump shall swell,

That wakes us on the vernal morn,

Sweet friends, a sweet furewell."

\section{Tro the atringed comtint.}

\section{Bryant}

THOU blossom bright with Autumn dew,

And eolored with the heaven's own blue,

That openest, wher the quiet light

Suceeds the keen and frosty night.

Thou eomest not when violets lean

O'er wandering brooks and spriugs unseen,

Ur columbines, in purple drest

Nod o'er the ground-bird's hidden nest.

Thou waitest late, and eom'st alone,

When woods are bare and birds are flown,

And frosts and shortening days portend

The aged year is near his end. 
Then doth thy sweet and quict cye

Look through its fringes to the sky,

Blue, blue, as if that sky let fall

A flower from its cerulean wall.

I would that thus, when I shall see

The hour of death draw near to me, Hopc, blossoming within my licart, May look to heaven as I depart.

\section{fficting Adntmun.}

Mrs. E. C. Kinncy.

THE autumnal glories all have passed away!

The forest leaves no more in glowing red

Give lurid tokens of their swift decay,

But scattered lie, and rustle to the tread,

Jike whispered warnings to the slumbering dead.

The naked trees stretch out their alms all day,

And each bald hill-top lifts its reverend hear.

As if for some new covering to pray.

Come, Winter, then, and spread thy robe of white, Above the desolation of this scenc;

And when the sun with gems shall make it bright, Or when its snowy folds by midnight's sheen

Are silvered o'cr with a serener light, We'll cease to sigh for Summer's living green. 


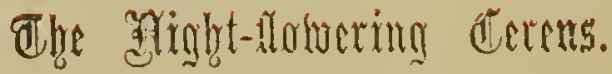

Anon

NOW departs day's garish light-

I Beauteous flower, lift thy head!

Rise upon the brow of night!

Haste, thy transient lustre shed!

Night has dropped her dusky veil--

All vain thoughts be distant far, While, with silent awe, we hail

Flora's radiant evening star.

See to life her beauties start;

Hail, thou glorious, matehless flower I

Much thou sayest to the heart

In the solemn, fleeting hour.

Ere we have our homage paid,

Thou wilt bow thine head and die;

Thus our вweetest pleasures fade,

Thus our brightest blessings fly. 
Sorrow's rugged stem, like thine,

Bcars a flower thus purcly bright;

Thus, when sunny hours decline,

Friendship sheds her cheering light.

Religion, too, that heavenly flower,

'That joy of never-fading worth: Waits, like thee, the darkest hour,

Then puts all her glories forth.

Then thy beautics are surpassed,

Splendid flower, that bloom'st to die;

For Friendship and Religion last

When the morning beams on high.

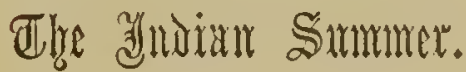

James Dixon.

WHEN the Summer breczes have died away,

And the Autumn winds are drear,

And the forests have changed their green array,

For the hues of the dying year;

There comes a season, brief and bright,

When the zephyrs breathe with a gentle swell, And the sunshine plays with a softer light,

Like the Suminer's last farewcll. 
The brilliant dyes of the Lutumn wonds Hare gliddened the forest bowers, And decked their pathless solitudes,

Like a blooming waste of flower's;

In the hidden depths no sound is hourl, Save a low and murmuring wail,

As the rustling leaves are gently stirred By the breath of the dying gale.

The hazy clouds in the mellow light, Fast with the breezes fly,

Where the far-off mountain's misty height Scems mingling with the sky; And the dancing streans rejoice again In the glow of the golden sun; And the floeks are glad in the grassy plann Where the sparkling water's run.

'Tis a season of deep and quiet thought, And it brings a caln to the breast :

And the hroken heart, and the mind o'erwrought, May find, in its stilluess, rest ;

For the gentle voice of the dying year, From forest and sunny plain,

Is sweet as it falls on the mourner's ear, And his spirit forgets its pain. 
Yet over all is a mantling gloom, Tliat saddens the gazer's heart;

For soon shall the Autumn's raried bloom

From the forest trees depart:

The bright leaves whirl in the cddying air,

Thcir beautiful tints are fading fust,

'l'he mountain tops will soon be bare,

And the Indian Summer past.

\section{Somirt.}

Keats.

WEN fitful gusts are whispering here and there

Among the bushes, half leafless and dry;

The stars look very culd about the sky,

And I have many miles on foot to fare;

$Y$ et fecl I little of the cool bleak air,

Or of the dead leaves rustling drcarily,

Or of those silver lamps that burn on high,

Or of the distance from home's plcasant lair,

For I am brimful of the fricndliness

That in a little cottage I have found

Of fair hair'd Milton's cloquent distress,

And all his love for gentlo Lyeid drowned;

Of lovely Jaura in her light green dress,

And faitliful Petrarcli gloriously crowned. 


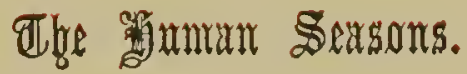

Keats.

GOUR seasons fill the measure of the year:

There are four seasons in the mind of man:

He has his lusty Spring, when fancy clear,

Takes in all beauty with an easy span:

He has his Summer, when luxuriously

Spring's honey'd cud of youthful thought he loves

To ruminate, and by such dreaming nigh

Is nearest unto heaven: quiet coves,

His soul has in its Autumn, when his wings

He furleth close; contented so to look On mists in idleness; to let fair things

Pass by unheeded as a threshold brook.

He has his Winter, too, of pale misfeature,

Or else he would forego his mortal nature. 


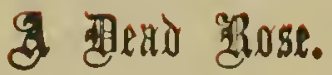

\section{Elizabeth Barrett Brononing.}

I.

$\mathrm{O}^{\mathrm{H}}$ rose! who dares to name thee? .

No longer roseate now, nor soft, nor sweet;

But pale, and hard, and dry, as stubble wheat,-

Kept seven years in a drawer-thy titles shame thee.

II.

The breeze that used to blow thee

Between the hedge-row thorns, and take away

An odor up the lane to last all day,-

If breathing now,--unsweetened would forego thee.

III.

The sun that used to smite thee, And mix his glory in thy gorgeous urn, Till beam appeared to bloom, and flower to burn,-

If shining now,-with not a hue would light thee. 
IV.

The dew that used to wet thee,

And, white furst, grow incarnadined, because

It lay upon thee where the erimson was,-

If dropping now, would darken where it met theo.

v.

The fly that lit upon thee,

To stretch the tendrils of his tiny feet,

Along thy leaf's pure edges, after heat,-

If lighting now, would coldly overrun thee.

VI.

The bee that once did suck thee,

And build thy perfumed ambers up his hive,

And swoon in thee for joy, till searee alive,-

If passing now, would blindly overlook thee.

VII.

The heart doth recognize thee,

Alone, alone! 'The heart doth smell thee sweet,

Doth view thee fair, doth judge thee most somplete-

Though secing now those changes that disguise thee

VIII.

Yes, and the heart doth owe thee

More love, dead rose! than to such roses bold

As Julia wears at danees, smiling cold !-

hic still upon this heart-which breass below theo! 


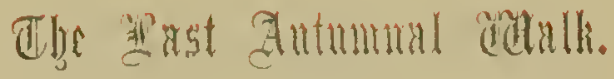

\author{
W. P. Palmer
}

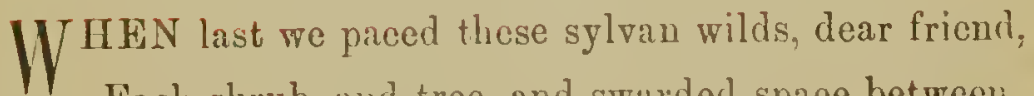

Fach shrub, and tree, and swarded space betweni,

Were flush with balmy June, and every nook

Of all the grove could boast, its own sweet lyre.

Our path was paved with shadows gayly fleeked

With drops of goldeu sunlight, as it wore

The print of angels' topaz-sandalud feet

Upon the glowing turf; and as we strayed

From glen to glen, no dusky forms kept pace

With our own steps along the browner shades

Thine arm was linked in mine, and oftentimes

We paused in very ecstasy amid

The ehoral gladness, and with merry lips

Broke into song spontaneous as the birds'.

Four moons have ruin their eycles since we stood

In Summer's green pavilion, then so gay,

But now so elanged wo searce can recognize

Onc form or feature of the faded scene. 
No bird recalls the melodies of June,

No flower its sweets, no bough its rustling shades!

Through all the roofless grove the sun stares in

With unobstructed gaze, and as we pass,

Twin shadows glide beside us arm in arm,

With silent footfall ou the dying leaves.

When now we pause, 'tis not with jocund lips

To swell the sylvan gladness, but to blend

Our sigh with nature's, as in funcral stole, Forlorn she follows Autumn's passing bier.

And, dearest, while I mark thy downeast eyes,

A mist is stealing o'er their wonted smiles;

And from their azure depths the silver rain

Falls audibly upon the rustling leaves.

Yet know, sweet mourner, and assured, take heart, That 'neath these russet cerements, not in death, But quick quieseenec, sleep the hopes of Spring!

No seed, no germ, no bulb of vanished flower,

No folded bud in all the bosky wild,

Is numbered with the dying or the dead:

$\mathrm{Nay}$, in the palsicd heart of these bare trees,

Life's lingering pulse, though faint and cold, still beata.

A. few brief months, and we will stand again

On the green summit of this forest knoll;

And list, enchanted, to the flying harps,

That fill the leafy aisles with vernal joy.

Before our steps the velvet sward again

Shall spread its sun-flecked shadows, and full oft 
By marge of murmuring stream, thy fairy foot

Shall sink in tufted violets instep deep;

What time the eornel and the hawthorn cast

Their snowy blossoms on the seented air,

And every floral ehrysalis awakes

To life and beauty from its shrouded sleep.

Meanwhile, dear friend, in our suburban eot, Thy furorite flowers shall bloom the Winter long, And day and night, with silent lips still breathe Sweet-seented thanks to thee; for in thy smiles They shall not miss the eharm of sunny skies, Nor in thy household songs, remember more The song of birds, but deem 'tis Summer still. Thyself their Flora, from thy genial hand Shall fall the needed dews eaeh eoming morn Till vernal suns and voice of vernal ehoirs Shall eall us forth to these dear wilds again ! 


\section{getinter.}

Southey.

A WHINKLED, erabbed man they licture thee, A Old Winter! with a rugged beard as gray

As the long moss upon the apple-tree;

Blue-lipt; an iee-drop at thy sharp, blue nose;

Close muffed up, and on thy dreary way

Plodding; alone, through sleet and drifting snows.

They should have drawn thee by the ligh-heapt irearth:

Old Winter! seated in thy great arı-ehair.

Watching the children at their Christmas mirth;

Or eircled by thein, as thy lips deelare

Some merry jest or tale of murder dire,

Or troubled spirit that disturbs the night,

l'ansing at times to rouse the mouldering fire,

Or taste the old October brown and bright. 


\section{Pines}

TO A FRIKNI, WITII SOME OIINESE OIRYSA NTIRMUMS.

$$
\text { W. P. Palner }
$$

'THE sunlight falls on hill and dale With slanter beam and fainter glow, And wilder on the ruthless gale The woodnymphs pour their sylvan wo:

Yct these fair forms of Orient raee Still graeed my garden's blighted bowers, And lent to Autumn's mournful face The eharm of Summer's rosy hours.

When shivering seized the dying year, They shrunk not from the icy blast; But stayed, like funeral friends, to eheer The void from whielı the loved had passed. 
Thus, Lady, when life's coming blight Has paled thy dimples' verual glow, And dimmed thine orbs of starry light, And flecked thy raven locks with snow;

Shall love, like these sweet lingerers, scem Still lovelier for thy faded prime, And gild with softer, holier beam The waste of Beauty's Autumn time!

\footnotetext{
䈍ines

TO AN ORANGH-TREE REOEIVED FROM THE WRST INUIRB LATR IN ATTUMN.
}

W. P. Palmer.

ROM thine Eden of the sea
Ilapless tree !

Where eternal Summer smiles

On the green Caribbean isles,

Borne to this ungenial elime

In the scowling Autumn timo

Poor forlorn one, be of cheer,

Hope is here! 
LINES TO AN ORANGE-TREE.

Thou shall find a friend in me,

Outeast tree!

Who will bear thee from the storm

To a shelter snug and warm-

An asylum Winter-proof;

When the snow is on the roof,

Or the sleet eomes down amain

On the pane.

Few delights, in sooth, to boast,

At the most.

Has our little, plain retrcat,

In its unpretending street;

Save a bird or two, a lute,

Pleasant books and nooks to suitm

And three pietures on the wall-

These are ali.

Yet while sadness rules the year

Far and near,

Thou shalt sit beside my hearth,

And its music and its mirth

From thy memory shall beguilc

E'en the eharms of that dear isle,

Whose enehantment far-off gleams

On thy dreams. 
And the nook assigned to thee, It shall be

Just the soothest, sunniest spot On the noon-side of our cot, Where, throughout the Winter day?

Little prattling ones shall play 'Mid the leafy shades so sweet, At thy feet.

So then, prithee, come with me, Hapless tree 1 And beneath my lowly roof, Let thy greeting be a proof 'That the peasant's humble door To the wretched evermore, With as wide a welcome swings As a king's! 


\section{gadinter 彩iece.}

James Russell Loroer. D OWN swept the ehill wind from the mountain peak,
From the snow five thousand Summers old;

On open wold and hill-top bleak

It had gathered all the cold.

And whirled it like sleet on the wanderer's cheek;

It earried a shiver every where

From the unleafed boughs and pastures bare;

The little brook heard it, and built a roof

'Neath which he eould house him, Winter-proof;

All night by the white stars' frosty gleams

He groined his arches and matehed his beams;

Slender and clear were his erystal spars

As the lashes of light that trim the stars;

IIe sculptured every Summer delight

In his halls and ehambers out of sight;

Sometimes his tinkling waters slipt

Down through a frost-leaved forest erypt,

Long, sparkling aisles of steel-stemined trees,

Bending to counterfeit a breeze; 
Sometimes the roof no fretwork knew

But silvery mosses that downward grew;

Sometimes it was carved in sharp relief

With quaint arabesques of ice-fern leaf;

Sometimes it was simply smooth and elear

For the gladness of heaven to shine through, and here

He had caught the nodding bulrush-tops

And hung them thiekly with diamond drops,

Which erystalled the beams of moou and sun,

And made a star of every one:

No mortal builder's most rare device

Could match this Winter-palace of ice;

'Twas as if every image that mirrored lay

In his depths screne through the Summer day,

Each flitting shadow of earth and sky,

Lest the happy model should be lost,

$\mathrm{Had}$ been mimicked in fairy masonry

By the elfin builders of the frost. 


\section{Whe Sitroby-Storm.}

Ralph Waldo Emerson.

NNOUNCED by all the trumpets of the sky, Arrives the Snow, and, driving o'er the fields,

Seems nowhere to alight: the whited air

Hides hills and woods, the river, and the heaven, And veils the farm-liouse at the garden's end.

The sled and traveller stopped, the courier's feet

Delayed, all friends shut out, the housemates sit

Around the radiant fireplace, inclosed

In a tumultuous privacy of storm.

Come see the north wind's masonry. Out of an unseen quarry evermore Furnished with tile, the ficree artifieer Curves his white bastions with projeeted roof Round every windward stake, or tree, or door. Speeding, the myriad-handed, his wild work So fanciful, so savage, naught eares he Eor number or proportion. Moekingly, 
On eoop or kennel he hangs Parian wreaths;

A swan-like form invests the hidden thorn; Fills up the farmer's lane from wall to wall, Maugre the farmer's sighis; and, at the gate, A tapering turret overtops the work. And when his hours are numbered, and the world Is all his own, retiring, as he were not, Leaves. when the sun appears, astnnished Art To mimic in slow struetures, stone by stone, Built in an age, the mad wind's vight-work, The frolie arehiteeture of the snow.

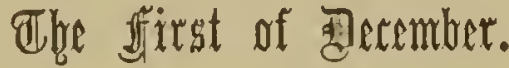

THOUGH no more the musing ear Delights to listen to the breeze

That lingers o'er the shade,

I love thee, Winter! well.

Sweet are the harmonies of Spring; Sweet is the Summer's evening gale; And sweet the Autumnal winds that shako

The many-eolored grove, 
And pleasant to the sobered soul

The silenee of the wintry seene,

When Nature shrouds herself, entranced

In deep tranquillity.

Not undelightful now to roam,

The wild heath sparkling on the sights;

Not undelightful now to pass

The forest's ample rounds;-

And see the spangled branches shine,

And mark the moss of many a hue

That varies the old tree's brown bark,

Or o'er the gray stone spreads;-

And see the elustered berries bright

Amid the holly's gay green leaves;

The ivy round the leafless oak

That clasps its foliage close.

So Virtue, diffident of strength,

Clings to Religion's former aid;

So by Religion's aid upheld

kindures ealamity.

Nor void of beauties now the spring,

Whose waters, hid from Summer sun,

Have soothed the thirsty pilgrim's ear

With more than melody. 
Green moss shınes there, with iee eneased; The long grass bends its spear-like form; And lovely is the silvery scene When faint the sunbeams smile.

Reflection, too, may love the hour When nature, hid in Winter's grave No more expands the bursting bud, Or bids the floweret bloom.

For Nature soon, in Spring's best charma, Shall be revived from Winter's grave; Expand the bursting bud again, And bid the flowers re-bloom. 


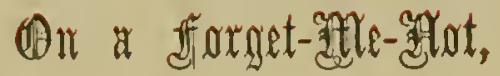 BROUGHT FROM BWITZERLAND.}

Mrs. Kemble.

RLOWER of the mountain! by the wanderer's hand Robb'd of thy beauty's short-lived sunny day;

Did'st thou but blow to gem the stranger's way, And bloom to wither in the stranger's land?

Hueless and scentless as thou art,

How mueh that stirs the memory,

How mueh, much more, that thrills the heart,

Thou faded thing, yet lives in thee!

Where is thy beauty? In the grassy blade

There lives more fragranee and more freshness now;

Yet oh! not all the flowers that bloom and fade

Are half so dear to memory's eye as thou.

The dew that on the mountain lies,

The breeze that o'er the mountain sighs,

Thy parent stem will nurse and nourish,

But thou-not e'en those sunny eyes,

As bright, as blue as thine own skies,

Thou faded thing! ean make thee flourish. 


\section{The endurustimus.}

James Montyome' $y$.

FAIR tree of Winter, fresh and flowering,

When all around is dead and dry;

Whose ruby buds, though storms are lowering,

Spread their white blossoms to the sky;

Green are thy leaves, more purely green,

Through every changing period seen;

And when the gaudy months are past

'Thy loveliest season is the last.

Be thou an emblem-thus unfolding

'The history of that maiden's mind,

Whose eye, these liumble lines beholding,

In them her future lot may find;

Through life's mutatious may she be

A modest evergreen, like thee:

Though blessed in youth, in age more blessed,

Still be her latest days the best. 


\section{Cune Sonth.}

R. H. Stowherri

TALI, ! thickly fall! thou Winter snow;

And keenly blow, thou Winter wind!

Only tho barren North is yours;

The South delights a Summer mind;

So fall and blow,

Both wind and snow,

My fancy to the South does go !

Half-way between the frozen zones,

Where Winter reigns in sullen mirth,

'The Summer binds a golden belt

About the middle of the Earth.

The sky is soft, and blue, and bright,

With purple dyes at morn and night;

And bright and blue the seas that lio

In perfect rest, and glass the sky;

And sunny bays with inlind curves

Round all along the quict shore; 
And stately palms in pillared ranks Grow down the borders of the banks, And juts of land where billows roar; The spicy woods are full of birds, And golden fruits and erimson flowers;

With wreathed vines on every bough, That shed their grapes in purple showers; The emerald meadows roll their waves, And bask in soft and mellow light; The vales are full of silver mist, And all the folded hills are bright; But far along the welkin's rim The purple erags and peaks are dim; And dim the gulfs and gorges blue, With all the wooded passes deep; All bathed in haze and washed in dew, And bathed in atmospheres of sleep. Sometimes the dusky islanders Lie all day long beneath the trees, And wateh the white elouds in the sky, And birds upon the azure seas; Sometimes they wrestle on the turf, And ehase each other down the sands; And sometimes elimb the blooming groves And pluek the fruits with idle hands; And dark-eyed maidens braid their hair

With starry shells, and buds, and leaves, And sing wild songs in dreamy bowers, And dance on dewy eves,- 
When daylight melts and stars are few, And west winds frame a drowsy tune, Till all the charmèd waters sleep

Beneath a yellow moon!

Here men may dwell, and moek at toil, And all the dull mechanic arts;

No need to till the teeming soil, With weary hands, and aehing hearts; No want ean follow folded palms, For Nature doth supply her alms With sweets purveyors eannot bring To graee the table of a King;

While Summer broods o'er land and sea. And breathes in all the winds, Until her presence fills their hearts, And moulds their happy minds! 


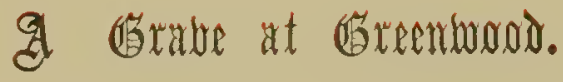

J. A.

$\mathrm{A}^{\mathrm{T}}$ Greenwood, where, through branches green,

The ocean's billowy breast is seen,

When dark the shades of evening grew,

And all around the green hill blew

Soft winds of Autumn's tranquil hours,

Faint with the breath of dying flowers,

An infant's little grave was made,

In which, with bitt'rest burning tears,

And broken-hearted sighs, was laid

The blossom of our later years.

Sweet place and still it is, and meet

- For the last rest of one so sweet.-

Bower'd round with trees whose ev'ry leat

Is eloquent of tender grief;

And graced with flowers divinely fair,

Which gentle hands have planted there,

And nurtured with a sad delight,

Not less to hallow than adorn;

Swect flowers! that bent in prayer all night,

Raise tearful eyes to Heaven at morn! 
Oh, loved and lost! there calmly sleep, And never wake again to weep; Safe in the cold earth's close embrace Rest thou alone a little space, And those thou lovedst most shall come, And join thee in thy peaceful home. Thy peaceful home, where ev'ry tear And cv'ry eare is all forgot; Where envy, hatred, strife, and fear, And sin, and sorrow enter not.

Though swect thy undisturbed sleep, A selfish sorrow bids us weep;

Still bleeds-though blessed now thou artThy mother's and thy father's heart. But though we think of thee as dead, Aud mould'ring in thy earthy bed, We know, thanks to benignant Heaven! ' When death destroyed thy mortal charms, That cherub wings to thee were given. To brar thee to thy Saviour's arms. 


\section{Christuras-然ag.}

Charles Harvey, (1640.)

TNFOLD thy face, unmask thy ray,

Shins forth, bright Sun, double the duy.

Juet no malignant, misty fume

Nor foggy vapor onee presume

To interpose thy perfeet sight.

This day which makes us love thy light,

Forever better that we eould

That blessed object onee behold,

Which is both the eireumference

And centrc of all excellence:

Or rather neither, but a treasure

Unconfined without measure,

Whose centre and circumfercnce,

Ineluding all pre-enincnee,

Fxcluding nothing but defeet

And infinite in each respeet,

Is equally both here and thero

And now, and then, and every where, 
And always, one, himself, the same,

A being far above a name.

Draw nearer, then, and freely pour

Forth all thy light into that hour

Whieh was erowned with His birth,

And made heaven envy earth.

Let not His birth-day elouded bo

By whom thou shinest and we see

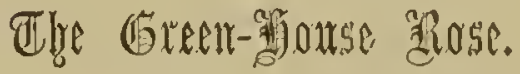

\section{Charlotte Smith}

$\mathrm{N}$ early Rose, borne from her genial bower,
Met the fond homage of admiring eyes, And while young Zephyr famed the lovely flower, Nature and Art contended for the prize.

Exulting Nature eried, "I made thee fair, "Twas I that nursed thy tender buds in dew;

I gave thee fragrance to perfume the air, And stole from beauty's eheck her blushing hue."

"Cease, goddess, eease," indignant Art replied, "And ere you triumph know that, but for me, This beauteous object of our mutual pride

Had been no other than a vulgar tree. 
"I watched her tender buds, and from her shade Drew each intruding weed with anxious care, Nor let the curling blight her leaves invade, Nor worm, nor noxious insect, harbor there.

"At length the beauty's loveliest bloom appears, And Art from Fame shall win the promised boon, While wayward April, smiling through her tears, Decks her fair tresses with the wreaths of June.

"Then, jealous Nature, yield the palm to me, To me thy pride its early triumph owes; Though thy rude workmanship produce the tree, "Twas Education formed the perfect Rose." 


\section{The (Thristmas-Tree.}

FROM TIIE GERMAN.

Rev. C. T. Brooks

'TIS Christmas eve,-full plain,-

A strange child runs about

Through street, and square, and lane;

To see the lights gleam out

From every window-pane.

Behold him stop and stare

At every house; he sees

The bright rooms, how they glare,

And all the lamp-full trees,-

Sad is he every where.

The poor child weeps: "To-night

Each little girl and boy

Their little tree and light

Can see and can enjoy,-

All,-all but me,-poor wight ! 
"Brothers and sisters, we

Once frolicked, hand in hand,

Around one sparkling tree;

But here, in this strange land,

No one remembers me.

"Now all the doors they close

Against the cold and me;

In all there gloomy rows

Of houses, can there bo

No spot for my repose?

"Will no one ope to me?

Naught will I touch or tako;

I'll only look and see

The pretty Christmas cake,-

The sight my feast shall bc."

He knocks at gate and door,

On shutter and on pane;

Within they laugh the more;

The poor child knocks in vain,

His little joints grow sore.

Fach fatber full of joy,

His children eyes with pride.

The mother hands the toy,

She thinks of naught beside;

None heeds the stranger boy. 
" Jear holy Christ, save thee,

No father and no mother

Have I on earth ; -0 , be

My Saviour and my brother,

fior none remembers me!"

Numbed with the biting blast,

He rubs his little hands, II ugs himself tight and fast, And in the bye-lane stands, His eyes to Heaven upeast.

Lo' with a little light,

Comes plodding up the street,

All dressed in spotless white,

Another ehild:-how sweet

His aeeents pieree the night I

I am the holy child

Jesus, and onee, like thee,

I roamed through eold and wild;

Poor wanderer, eome to me,

For I am meek and mild!

"I will not seorn thy prayer;

The poor I love to bless,

And grant my tender eare

Here in the streets no less

Than in the parlor there, 
"And now I'll let thee see,

Here in the open air,

Thou stranger-ehild, thy tree,-

And none so bright and fair

In all the rooms ean be."

Then pointed with his hand

Child Jesus to the sky :-

A mighty tree did stand,

Crowded with stars, so high,

Its boughs the wide heaven spanned.

How far, and yet how near,

The sparkling arehes seem!

Poor Child! it did appear

Like to a fairy dream,

All was so calm and elear.

There,-in the shining sky,-

There stood his Christmas-treo;

And little angels nigh

Reached down so lovingly,

And drew him up on high.

And homeward now he goes,

The little stranger-ehild,

With Jesus to repose,-

The Saviour meok and mild,-

And soon forgets his woes. 


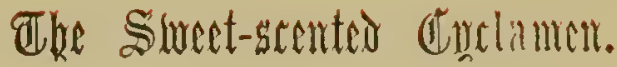

W/s. Southey.

I LOVE thee well, my dainty flower !

My wee, white, eowering thing,

That shrinketh like a cottage maid,

Of bold, uneivil eyes afraid,

Within thy leafy ring!

I love thee well, my dainty dear!

Not only that thou'rt fair,-

Not only for thy dowueast eye,

Nor thy sweet breath, so lovingly,

That woos the ealler air.

But that a world of dreamy thoughts

The sight of thee doth bring.

Like birds who've wandered far from henee.

And come again (we know not whenee),

A't the first eall of Spring.

As here I stand and look on thee,

Before mine eyes doth pass-

(Clearing and quick'ning as I gaze,)

An evening secne of other days,

As in a magie glass. 
Sweet air, sweet flowers, sweet social looks :-

Dear friends!-young, happy hearts!

How now! what! all alone am I?

Come they with eruel mockery,

Like shadows to depart?

Ay, shadows all-gone every face

I loved to look upon-

Hushed every strain I loved to hear,

Or sounding in a distant ear--

"All gone!-all gone!-all gone!"

Some far away in other lands-

In this-far worse than dead-

Some in their graves laid quietly-

One, slumb'ring in the deop, deep sea--

All gone!-all lost!_all fled!

And here am I-I live and breathe,

And stand, as then I stood,

Beside my little dainty flower-

But now, in what an altered hour;

In what an altered mood!

And yet I love to linger here-

To inhale this od'rous breath-

(Faint as a whisper from the tomb, )

To gaze upon this pallid bloom

As on the face of Death. 


\section{Pose Stmotisty.}

\section{Miss F. M. Caulkins.}

THE Rose I sing sprung from no earthly mould, Nor drank the sunbeams or the falling dew,

It bore no thorns, and in its bosom's fold

No lurking worm or eating canker grew.

* They who have seen Weir's picture of the Embarkation of the Pilgrims, recently suspended in the Capitol at Washington, will re member the beautiful countenance of Rose, the wife of Capt. Miles Standish. They belonged to that iutrepid band of Puritans who left Fngland for conscience' sake; and after residing awhile in Ilollancl, same to America in the Mayflower, commenced the first settlement of New England,

\section{"And left unstained what there they found,}

Freedom to worship God."

This little colony landed at Plymouth, in Massacliusetts, December 22d, 1620. Among the first victims to the hardships they experienced from cold, famine, and want of shelter on an iuhuspitable coast, was the beautiful Rose Standish. She died in January. Her husband is well known ar the military champion of the infant coluny. 
Soft were its hues-'twas love's, 'twas beauty's own, The favorite of the hall, the field, the bower;

A lRose in whieh a radiant spirit shoneNot the frail queen of thorn, and leaf, and flower.

A graft it was from Sharon's beauteous Rose, Nursed with the gentlest dews of Palestine: A mind, a heart, a glory, a repose, Beamed from its depths and showed the root divine

Rude storms, and perseeution's deadly hail, Beat on its head, yet lovelier it became: So oaks grow strong while wrestling with the galc, So glows the molten silver in the flame.

The ripening blossom opened rieh and fair, And filled with sweetness all the winds around; $\Lambda$ mail-elad warrior, struck with eharms so rare, This Rose of beauty to his bosom bound.

I saw it on the Mayflower's saered floor, Beneath the banner "God with us," recline: That deck the sifted wheat of kingdoms bore, There in its embryo lay New England's vine.

Behold the group: the parting pang is past; They launch their lonely fortunes on the sca; Back to thr land the soul's last fetters cast, And with the freo winds join their anthems free. 
Freedom, the Bible, virtue, faith, and prayer Embarked with them and daily sate beside; While unseen angels strengthened them to bear, And God's own finger was their wondrous guide.

Then did our Rose, o'cr famine, gricf and eare, Cast its bright fush, its incense swect diffuse; The warrior by whose side it flourished fair, Was all enveloped with its beauteous hues.

Long on the dreary oecan doomed to roam,

New sweets, new beauties still its leaves disclose;

Till in this late-found world, the pilgrim's home, It fixed its root, our lovely Plymouth Rose.

Death found it there, and eut the slender stem:

It fell to carth; yet still it lives, it glows;

For Christ hath set it in his diadem, And ehanged to fadeless Amarantl our Rose. 


\section{Dhe (1)penting Heat.}

Shelley.

RPHAN hours, the year is dead,
Come and sigh, come and weep I

Merry hours, smile instead,

For the year is but asleep.

See, it smiles as it is sleeping,

Mocking your untimely weeping.

As an earthquake rocks a corse

In its coffin in the clay,

So white Winter, that rough nurse,

Rocks the dead-cold year to-day;

Solemn hours! wail aloud

For your mother in her shroud.

As the wild air stirs and sways

The tree-swung cradle of a child,

So the breath of these rude days

Rocks the year:-be calm and mild,

Trembling hours; she will arise

With new love within her eyes. 
January gray is here,

Like a sexton by her grave;

February bears the bier,

March with grief doth howl and rave,

And April weeps-but, $\mathrm{O}$ ye hours !

Follow with May's fairest flowers.

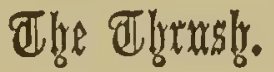

\section{Burns.}

CING on, sweet Thrush, upon the leafless bough;

1 Sing on, sweet bird, I listen to thy strain;

Sce, aged Winter, 'mid his surly reign, At thy blithe carol clears his furrowed brow,

So in lone Poverty's dominion drear

Sits meck Content with light, unanxicus heart,

Welcomes the rapid movements, bids them parts

Nor asks if they bring aught to hope or fear.

I thank thee, Author of this opening day!

Thou whose bright sun now gilds the Orient skies!

Riches denied, thy boon was purer joys,

What wealth could never give nor take away!

Yet come, thou child of poverty and care;

The mite high Heaven bestow'd, that mite with thee I'll share. 


\section{The first of amartw.}

\section{Southey:}

COME, melancholy moralizer, eome!

Gather with me the dark and wintry wreath.

With me engarland now

The sepulchre of Time.

Come moralizer, to the funeral song!

I pour the dirge of the departed days;

For well the funeral song

Befits this solemn hour.

But hark! even now the merry bells ring round With clamorous joy to weleome in this day-

This eonseerated day

To joy and merriment.

Mortal! while Fortune, with benignant hand lills to the brim thy cup of happiness,

Whilst her unelowded sun

Illumes thy Summer day :- 
Canst thou rejoice-rejoice that Time flies fast, That night shall shadow soon thy Summer sunThat swift the stream of Years

Rolls to Eternity?

If thou hast wealth to gratify each wish,

If power be thine, remember what thou art!

Remember thou art Man,

And Death thine beritage.

Iast thou known Love? Doth 13eauty's better sun Chcer thy fond lieart, with no capricious smile, Her eye all eloquenee, All harmony her voice?

O state of happiness !- Hark how the gale Moans deep and hollow through the leafless grove!

Winter is dark and eold-

Where now the charms of Spring?

Say'st thou that Faney paints the future seene In hue too sombrous? That the dark-stoled maid Witl frowning front severe Appals the shuddering soul?

And wouldst thou bid me court her fairy form, When, as she sports her in some happier mood,

- Her many eolored robes

Float varying in the sun? 
Ah! vainly does the Pilgrim, whose long road Leads o'er a barren mountain's storm-vexed height,

With wistful eye behold

Some quiet vale, far off.

And there are those who love the pensive song;

To whom all sounds of mirth are dissonant

Them in aceordant mood

This thoughtful strain will find.

For hopeless Sorrow hails the lapse of Time,

Rejoicing when the fading orb of day

Is sunk again in night,

That one more day is gone!

And he who bears Afflietion's heavy load With patient piety, well-pleased he knows

The World's a pilgrimage,

The Grave his inn of rest. 


\section{detarsmigrattot.}

TO A YOUNG IADY WHO SAID SHE "WISHED SHh WAS A FLOWEK"

\section{Anon.}

To be a flower! which would you be, A snow-drop, or a violet?

The pink-eyed humble daisy,

Or riehly-scented mignonette?

Or daffodil in Spring so gay,

That children sing "grows in a well?"

Or elustered blossoms of sweet May,

Or woodland bunehes of blue-bell?

Or jasmine, all so snowy white,

'That elimbs up to my lady's bower?

$\mathrm{Or}^{*}$ star of Bethlehem's golden light.

Or the sweet woodbine's roving flower?

There is a little azure eye

'That peeps around the peasant's eot, Aud whispers in soft melody,

"Forget me not-forget me not." 
Will you be that memorial dear Of those who are so far away, Whose absenee wakes the frequent tear, Whose presenee turns the night to day:

Or will you be the passion-flower, 'I'hat spreads its hallowed radianeo round; That to a temple turns the bower, And marks the plaee for holy sround?

Carnation! robed in virgin white, Seems like an angel on the earth, Sc pure; so spotless, and so bright, As though it elaimed a hearenly birth;

Compare it with more mortal sights, It blooms a lady of degree, Such as were served by gallant knights In the fair fields of ehivalry.

The crimson stoek, of ten weeks' pride; Ten weeks! it eharms us all the year; Or primal rose, when eventide Bids its pale blossoms reappear;

Or June's own rose-that sovereign flower; Oh, that decides the floral strife;

What nymph that loves not royal powerThat would not be a queen for life? 
Then be it so, beloved maid,

But let me fix thy palaee dome;

Go, reign unrivalled in the shade

Of a proteeting, happy home.

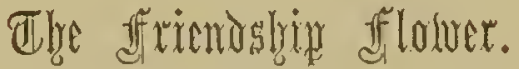

Milnes.

WHEN first the Friendship Flower is planted Within the garden of your soul,

Little of eare or thought is wanted

To guard its beauty fresh and whole;

But when the full impassioned age

Has well revealed the magie bloom,

A wise and holy tutelage

Alone aroids the open tomb.

It is not absenee you should dread,-

For absenee is the very air

In which, if sound at root, the head

Shall wave most wonderful and fair:

With sympathies of joy and sorrow

Fed, as with morn and even dews,

Ideal eoloring it may borrow

Richer than ever carthly hues. 
But oft the plant, whose leaves unsere

Refresh the desert, hardly brooks

The common peopled atmosphere

Of daily thoughts, and words, and looks;

It trembles at the brushing wings

Of many a careless fashion fly,

And strange suspicions aim their sungs

To taint it as they wanton by.

Rare is the beart to bear a flower,

That must not wholly fall or fade

Where alien feelings, hour by hour,

Spring up, beset, and overshade;

Better, a child of care and toil,

To glorify some needy spot,

Than in a glad, redundant soil

To nine neglected and forgot.

Yet when, at last, by human slight,

Or close of their permilled day.

From the bright world of life and light

Such fine creations lapse away,-

Bury the relics that retain

Sick odors of departed pride,-

Hoard, as ye will, your memory's gain,

But leave the blossoms where they died. 


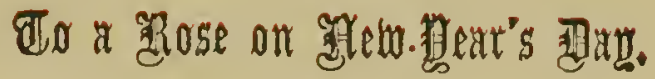

Anon.

$\mathrm{B}^{\mathrm{Y}}$ what rule, stranger, shall we fix thy date?

Art thou a thing of last year, or of this?

With breathless longing the soft snow-flakes wait, Thy lightly tinted virgin lips to kiss.

With all around thou seem'st a contrast strange,

Yet none, I ween, for that will love thee less;

Heedless alike of fortune, and of change,

Thou, with vast strivings, into life didst press.

No lovelier object decks creation's free;

No sight so cheering as a rose fresh blown;

But Nature has enhanc'd thy modest grace,

Because thou cam'st in Winter, and alone.

Thou art a being fair, a beauty bright;

A prophet, whispering of joy to come;

A spirit, pointing to the realms of light,

Where Spring eternal reigns, in peerless bloom. 
ReLigion cheers, like thee, life's darkest shade, And blooms alone 'mid wintry desolations. When Summer flowers, and earthly pleasures fade, Filling the soul with bright anticipations.

Sweet flower! thou dost this sentiment convey(Oh, that its truth might every heart impress) When Nature's strength shall fail-her power decay, The soul shall brighter bloom, in loveliness.

\section{estrergreents.}

Pinckiney

WHEN Summer's sunny hues adorn Sky, forest, hill and meadow,

The foliage of the Evergreens

In contrast, seems a shadow.

But when the tints of Autumn have

Their sober reign asserted, The landscape that cold shadow shows Into a light converted.

Thus thoughts that frown upon our mirth Will smile upon our sorrow, And many dark fears of to-day May be bright hopes to-morrow. 


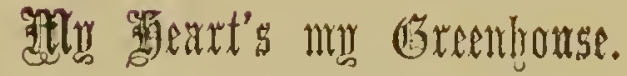

W. L.

MY heart's to me a pleasant Greenhouse, Where, when Winter winds blow chill, And blasted all lie Summer flowerets, Sheltered bloom my flowerets still.

All around its erystal easements

Clusters wild the passion-vine; Veiling brightly elouds and shadows, But admits the dear sunshine.

There the perfume of the lily Mingles with the damask rose; Deeply sighs the orange-blossom And the bright carnation glows.

There the timid violet trembles; Heliotropes their fragrance shed; And the star of Bethlehem watehes O'er the heart's-ease' lowly bed. 
In its midst a fountain sparkles, That, witl gentle, silvery showers, Casts its spray of diamond dew-drops 'To refresh the grateful flowers.

My free birds sing sweetly, leeplySing to me the livelong day; Of the Past-the Present-Future, One resounding, thrilling lay.

Warmly nurtured is my GreenhouseWarmed by fires, lit from on high ; Flowers would perish were it colder, And my happy birds would die.

Once my opening roses eireled Round a tree I deemed secure; But no root it had, and even Lightest storms could not endure.

So the roses bleeding, writhing Sadly lay upon the ground, Till the passion-vine entwined then, And the ivy elasped them round.

Now, though of their blushing petals To the fallen tree still turn; They. in friendship firm, unchanging, Soon forgetfulness will learn. 
And my Grecnhouse I will cherish,

For its flowers will never die;

They will join the one great garden,

And for ever bloom on high.

May its weeds be stifled; ' 3

By the Gardener's watc ... care;

For above in that bright Eden

Nought may bloom but flowerets fair.

\section{Tho a seatitueted a dose.}

Mrs. Whitman.

PAI E flower-pale, fragile, faded flower;

What tender recollections swell,

What thoughts of deep and thrilling power

Are kindled by tliy mystic spell!

A charm is in thy faint perfume,

'To call up visions of the past,

Which, through my mind's o'ershadowing gloom,

"Rush, like the rare stars, dim and fast."

And loveliest shines that evening hour,

More dear by time and sorrow made, When thou wert culled (love's token flower!)

And on my throbbing bosom laid. 
On eve's pale brow one star burned bright, Like heavenward hope, whose soothing beam, Is veiled from pleasure's dazzled sight, To shine on sorrow's diadem.

Bright as the tears thy beauty wept, The dew-drops on thy petals lay; Till evening's silver winds had swept Thy cheek, and kissed them all away.

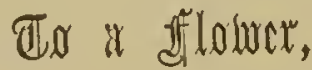
FOUND IN A OHEST OF TEA.

\section{W. Parker}

1 FADED blue-bell in a chest of tea, A A messenger from distant regions sentA voyager aeross the mighty sea-

A link 'twixt continent and continent! Though but a waif-a trifle-thou to me Of many scenes and thoughts art eloquent; Of scenes fantastic, beautiful and strange, As lie within the world's unbounded range. 
The ecntral flowery kingdom was thy home,

And thou, a witness of its light and bleom, Art sent of Hearen, if not of $\mathrm{men}$, to roam,

Imprisoned darkly in a fragrant tomb, And tossed upon the surging ocean's foam,

Until, eushrined within a student's room, I'hy erushed and brittle leaflets are unfurled To greet the sunhine of a Western World.

()ir, that thy quickened life could flow again, And that we knew the silent thoughts of flowers! Thy deep-blue eyes and leafy lips would then Declare if other skies are sweet as oursIV ould speak of wondrous elinies beyond our ken, And wile away the silver-sandaled hour's With many tales of that mysterious land. Around whose breadth the walls of ages stand.

And yet 'tis not because an unknown soil l3ore thee, that thou to me a treasure art; For there man's lot is no less one of toil;

He bears about the self-same human heart. IIe knows the same sweet peace or wild turmoil,

And frets out life in eamp, and court, and mart; The same winds blow, no other sunlight warns, And all is Nature's self in other forms. 
This simple flower has deeper thoughts for me, For that, like mine and evury living soul,

It has its own unravelled history

Recorded on no earthly page or scroll;

For that it is a thread of sympathy

With lands beyond where other oceans roll;

Within the infant rind of this small flower, Memory bath "residence," and Fancr "power."

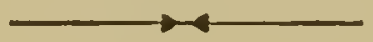

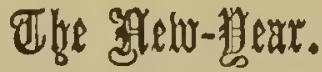

Tennyson.

J IP down upon the northern shore,

Oh! sweet New-Year, delaying long;

Thou doest expectant Nature wrong,

Delaying long; delay no more.

What stays thee from the clouded noons,

Thy sweetness from its proper place?

Can troubles live with A pril days,

Or sadness in the Summer moons?

Bring orchis, bring the fox-glove spire,

The little speedwell's darling blue,

Deep tulips dashed with fiery dew,

Laburnums, dropping-wells of fire. 
Oh thou, New-Y car delaying long,

Delayest the sorrow in my blood, That longs to burst a frozen bud, And flood a fresher throat with song.

\section{CEbildrrood.}

Anon.

T NEVER wander 'mong the flowers,

1 But mem'ry will be straying

To other days and other hours,

When childhood went a-May-ing.

O precious days, O happy hours, How mem'ry backward lingers, To pluck again the dewy flowers, With childhood's rosy fingers.

$\mathrm{O}$ give me back that olden time, When childhood knew no sorrow; But only cared to pluck life's flowers, And dreamed not of the morrow. 


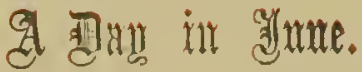

\section{J. R. Loroell.}

WHAT is so rare as a day in June? Then, if ever, eome perfeet days;

Then Heaven tries the earth if it be in tune, And o'er it softly her warm ear lays:

Whether we look, or whether we listen, We hear life murmur or see it glisten; Every elod feels a stir of might, An instinet within it that reaches and towers, And, grasping blindly above it for light, Climbs to a soul in grass and flowers;

The flush of life may well be seen Thrilling baek over hills and valleys;

The cowslip startles in meadows green, The buttereup eatehes the sun in its chaliee, And there's never a leaf or a blade too mean To be some happy ereature's palace.

The little bird sits at the door in the sun, Atilt, like a blossom, among the leaves,

And lets his illumined being o'errun With the deluge of Summer it reeeives. 
His mate feels the eggs bencath her wings, And the heart in her dumb breast flutters and sings; He sings to the wide world, and she to her nest,In the niee ear of nature which song is the best?

Now is the high-tide of the year,

And whatever of life hath ebbed away

Comes flooding back, with a rippling cheer,

- Into every bare inlet, and ereek, and bay.

Now the heart is so full that a drop overfills it,

We are liappy now beeause God so wills it;

No matter how barren the past may have been, "Tis enough for us now that the leaves are green ;

We sit in the warm shade and feel quite well

How the sap ereeps up and the blossoms swerl;

We may shut our eyes, but we eannot help knowing

That skies are elcar and grass is growing;

The breeze comes whispering in our ear,

That dandelions are blossoming near-

That maize has sprouted, that streans are flowing,

That the river is bluer than the sky;

That the robin is plastering his house hard by ;

And if the breeze liept the good news baek,

For other eouriers we should not lack;

We eould guess it all by yon heifer's lowing,-

And hark! how elcar bold ehantieleer,

Warmed with the new wine of the year

Tells all in his lusty erowing ! 
Joy comes, grief goes, we knuw not how; Every thing is happy now,

Every thing is upward striving;

'Tis as easy now for the heart to be true,

As for grass to be green or skies to be blue,'Tis the natural way of living:

Who knows whither the clouds have fled?

In the unscarred heaven they leave no wako; And the eyes forget the tears they have shed, The heart forgets its sorrow and ache; The soul partakes the season's youth, And the exulphurous rifts of passion and woe Lie deep 'neath a silence pure and smooth, Like burnt-ont craters healed with snow. 


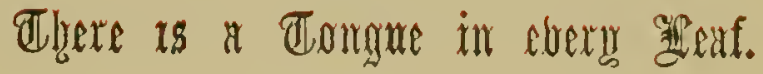

\section{Anon}

THERE is a tongue in every leaf-

A roiee in every rill;

A voiee that speaketh every where-

In flood and fire, through earth and air.

A tongue that is never still.

'Tis the great Spirit wide diffused

Through every thing we see,

That with our spirits communeth,

Of things mysterious, - Life and Death,

Time and Eteruity.

I see Him in the blazing sun,

And in the thunder-cloud;

I hear Him in the mighty roar

That rusheth through the forests hoar,

When winds are piping loud. 
I see Him, hear Him, every where,-

In all things,-darkness, light,

Silence, and sound,-but most of all,

When slumber's dusky curtains fall,

At the dead hour of night.

I feel Him in the silent dews

By grateful earth betrayed;

I feel Him in the gentle showers,

The soft south wind, the breath of flowers,

The sunshine and the shade.

And yet (ungrateful that I am)

I've turned, in sullen mood,

From all these things whereof $\mathrm{He}$ said,-

When the great whole was finished,-

That they were "very good."

My sadness on the loveliest things

Fell like ungrateful dew;

The darkness that encompassed me,

The gloom I felt so palbably,

My own dark spirit threw.

Yet He was patient,-slow to wrath,

Though every day provoked

By selfish pining, discontent, Acceptance cold, or negligent,

And promises revoked. 
THE TOWN AND COUNTRY CHILD.

And still the same rich feast was spread For my insensate heart!

Not always so: I woke again,

'To join ereation's rapturous strain, "Oh! Lord, how good thou art!"

The clouds drew up,-the shadows fled; 'The glorious sun broke out;

And love, and hope, and gratitude,

Dispelled that miserable mood Of darkness and of doubt.

\section{$\longrightarrow \cdots$

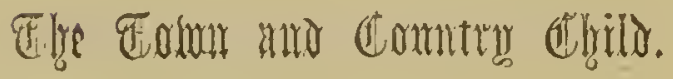 \\ Allan Cunningham.}

CHIID of the eountry! free as air

Art thou, and as the sunshine fair;

Born. lilie the lily, where the dew

Lies odnrous when the day is new,

Fed 'mid the May flowers like the bee

Nursed to sweet music on the knee,

Isull'd in the breast to that glad tune

Whieh winds make 'mong the woods of June:

I sing of thee; - 'tis sweet to sing

Of such a fair and gladsome thing. 
Child of the town! for thee I sigh;

A gilded roof's thy golden sky,

A carpet is thy daisicd sod,

A narrow street thy boundless road;

Thy rushing deer's the clattering tramp

Of watehmen, thy best light's a lamp.

Through smoke, and not through trellised vines

And blooming trees, thy sunbeam shines;

I siug of thec in sadness; where

Else is wreck wrought in aught so fair?

Child of the country! thy small feet

Tread on strawberries red and sweet;

With thee I wander forth to see

The flowers which most delight the bee;

The bush o'er which the throstle sung

In April, while she nursed her young;

The den beneath the sloe-thorn, where

She bred her twins, the tinorous bare;

The knoll, wrought o'er with wild blue-bells,

Where brown bees build their balmy cells;

The greenwood stream, the shady pool,

Where trouts leap when the day is cool;

The shilfer's nest that seems to be

A portion of the sheltering tree,-

And other marvels, which my verse

Can find no language to rehearse. 
Child of the town! for thee, alas! Glad nature spreads nor flowers, nor grass;

Birds build no nests, nor in the sun Glad streams come singing as they run:

A Maypole is thy blossom'd tree;

A beetle is thy murmuring bee;

Thy bird is eaged, thy dove is where Thy poulterer dwells, beside thy hare; Thy fruit is pluck'd, and by the pound Hawk'd elamorous all the eity round; No roses, twin-born on the stalk, Perfume thee in thy evening walk; No voice of birds, - but to thee eomes The mingled din of ears and drums, And startling cries, such as are rife When wine and wassail waken strife.

Child of the eountry! on the lawn I see thee like the bounding fawn, Blithe as the bird which tries its wing The first time on the winds of Spring; Bright as the sun when from the eloud He comes as cocks are erowing loud; Now running, shouting, 'mid sunbeams, Now groping trout in lucid streams, Now spiuning like a mill-wheel round, Now hunting echo's empty sound, 
Now climbing up some old tall tree-

For climbing sake. 'Tis sweet to thee

To sit where birds can sit alone,

Or share with thee thy venturous throne.

Child of the town and bustling street, What woes and snares await thy feet 1 Thy paths are pared for five long miles, Thy groves and hills are peaks and tiles; Thy fragrant air is yon thick smoke, Which shrouds thee like a mourning cloak; And thou art cabin'd and confined, At once from sun, and dew, and wind;

Or set thy tottering feet but on Thy lengthen'd walks of slippery stone:

The coachman there careering reels With goaded steeds and maddening wheels; And Commerce pours each prosing son In pelf's pursuit and hollos 'Run :' While flushed with wine, and stung at play, Men rush from darkness into day. The stream's too strong for thy small bark; There nought can sail, save what is stark.

Fly from the town, sweet child! for health. Is happiness, aud strength, and wealth There is a lesson in each flower, A story in each stream and bower; 
On every herb on which you tread Are written words which, rightly read, Will lead you from earth's fragraut sod, To hope, and holiness, and God.

\section{ช}

A ERAGMENT.

Ieigh IIunt.

A GOOD old enuntry lodge, half hid with blooms Of honeyed green, and quaint with straggling rooms, A few of which, white-bedded, and well-swept, For friends whose names endeared them should be kept; Of brick I'd have it, far more broad than high. With green up to the door, and elm-trees nigh; And the warm sun should have it in his eye. The tip-toe traveller pecping through the boughs Of my low wall, should bless the pleasant house; And, that my luek might not seem ill-bestowed, A bench and spring should greet him on the road.

My grounds should not be large; I like to go To Nature for a range and prospeet tou, And cannot fancy she'll comprise for we Eveu in a park her all-sufficiency. 
Besides, my thoughts fly far, and when at rest,

Love, not a wateh-tower, but a lulling nest.

But all the ground I had should keep a look Of Nature still; have birds'-nests and a brook;

One spot for flowers, the rest all turf and trees, For I'd not grow my own bad lettuees.

I'd build a walk, however, against rain, Long, peradventure, as my whole domain; And so be sure of generous exereise, The youth of age, and medieine of the wise.

\section{đld the 整utterthy.}

Rogers.

CHILD of the Sun! pursue thy rapturous flight, Mingling with her thou lov'st in fields of light ;

And where the flowers of Paradise unfold, Quaff fragrant neetar from their eups of gold. There shall thy wings, rieh as an evening sky, Fixpand and shut, with silent eestasy!

Yet wert thou onee a worm; a thing that erept On the bare earth, then wrought a tomb and slept. And such is man; soon from his eell of elay To burst, a seraph in the blaze of day. 


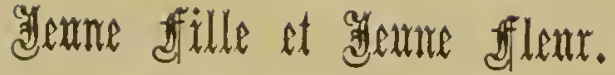

Chateaubriand.

TL deseend le eereucil: et les roses sans tache Qu'un père y déposa, tribut de sa douleur, Terre, tu les portas; et maintenant tu oaches

Jeune fille et jeune fleur.

Ah! ne les rends jamais à ce monde profane, A ee monde de deuil, d'angoisse et de malheur; Le vent brise et flétrit, le solcil brûle et fane, Jeune fille et jeune fleur.

Tu dors, paurre Elise, si lígère d'années, Tu ne erains plus du jour le poids et la chaleur! Elles ont achevé leurs fraiches matinées, Jeune flle et jeune fleur.

Mais ton père, Elise, sur ta eendre s'incline, Aux rides de son front a monté sa paleur, Et vieux chêne, le temps fauche sur sa racine Jeune fille et jeune fleur. 


\section{The equasedro.}

Kebla

WHEN Nature tries her finest touch, Weaving her vernal wreath,

Mark ye; how close she veils her round, Not to be traeed by sight or sound,

Nor soiled by ruder breath?

Who ever saw the earliest rose

First open her sweet breast?

Or when the Summer sun goes down,

The first soft star in evening's crown,

Light up her gleaming erest?

Fondly we seek the dawning bloom

On features wan and fair,

The gazing eye no change ean trace,

But look away a little space,

Then turn, and lo! 'tis there. 
But there's a sweeter flower than e'er Bluslied on the rosy spray,A brighter star, a richer bloom, Than e'er did western heaven illume At elose of Summer day.

'Tis Love, tlie last, best gift of Heaven, Love, gentle, holy, pure;

But tenderer thall a dove's soft eye, The searehing sun, the open sky, She never eould endure.

Even human Love will shrink from sight Here in the coarse, rude earth:

How then should rash, intruding glance, Break in upon her saered trance Who boasts a heavenly birth?

So still and secret is her growth, Ever the truest heart,

Where deepest strikes her kindly root

For hope or joy, for flower or fruit,

Iueast knows its happy part.

God only, and good angels, look

Behind the blissful sereen, As when, triumphant o'er his woes, The Son of God by moonlight rose, By all but Heaven unseen :- 
As when the Holy Maid beheld

Her risen Son and Lord:

Thought has not colors half so fair

That she to paint that hour may dare,

In silence best adored.

The gracious Dove that brought from heaven

The earnest of our bliss,

Of many a ehosen witness-telling,

On many a happy vision dwelling,

Sings not a note of this.

So, truest image of the Christ,

Old Israel's long-lost son,

What time, with sweet, forgiving cheor

He called his conseious brethren near,

Would wecp with them alone.

He could not trust his melting soul,

But in his Maker's sight, -

Then why should gentle hearts and truo

Bare to the rude world's withering view

Their treasure of delight !

No,-let the dainty rose awhile

Her bashful fragrance hide-

Rend not her silken veil too soon,

But leave her, till her own soft noon,

To flourish and abide. 


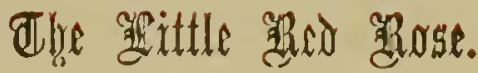

Goethe.

A BOY eaught sight of a rose in a bower-

A little rose, slyly hiding

Among the boughs; $\mathrm{O}$, the rose was bright

And young, and it glimmered like morning light;

The urchin sought it with haste; 'twas a flower

A child indeed might take pride in-

A little rose, little rose, little red rose,

Among the bushes hiding.

The wild boy shouted, "I'll pluek thee, rose,

Little rose, vainly hiding

Among the boughs;" but the little rose spoke-

"I'll prick thee, and that will prove no joke;

Unhurt, $O$ then I will moek thy woes,

Whilst thou thy folly art ehiding."

Little rose, little rose, little red rose,

Among the bushes hiding I 
But the rude boy laid his hands on the flower,

The little rose vainly hiding

Among the boughs; $O$ the rose was caught!

But it turned again, and prieked and fought,

And left with its spoiler a smart from that hour,

A pain for ever abiding;

Little rose, little rose, little red rose,

Among the bushes hiding!

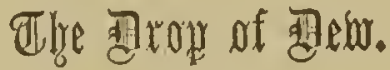

Anon.

CEE how the orient dew,

Shed from the bosom of the morn,

Into the blowing roses,

Is eareless of its mansion new;

For the clear region where 'twas born

It in itself ineloses,

And in its little globe's extent,

Frames, as it ean, its native element.

How it the purple flower does slight,

Scarce touehing where it lies;

But gazing back upon the skies,

Shines with a mournful light,

Like its own tear! 
Bccause so long divided from the sphere, Restless it rolls, and inseeure, Trembling lest it grow impure; Till the warm sun pities its pain, And to the skies exhales it baek again So the soul, that drops that ray, Of the clear fountain of eternal day, Could it within the human flower be seen, Remembering still its former height, Shuns the sweet leares and blossoms green; And, recollecting its own light, Does, in its pure and eireling thoughts, express The greuter heaven in a heaven less.

In how eoy a figure wound, Every way it turns away! So, the world exeluding round, $Y$ et reeciving in the day:

Dark beneath, out bright above;

Here disdaining, there in love.

How loose and easy hence to go,

How girt and ready to aseend!

Noring but on a point below,

It all ahout does upward bend.

Sueh did the manna's saered dew distil, White and entire, although eongcaled and ehill; Congealed on earth; but does, dissolving, run Into the glories of the almighty sun. 


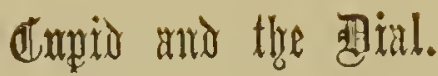

Anon:

NE day, young frolic Cupid tried To scatter roses o'er the hours, And on the dial's face to hide

The course of time with many flowers.

By chance his rosy wreaths had wound

Upon the hands, and forced them on; And when he looked again, he found The hours had passed, the time was done.

"Alas!" said Love, and dropped his flowers, "I've lost my time in idle play;

The sweeter I would make the hours, The yuicker they are passed away:" 


\section{To, lobelly Rose.}

\section{Talles}

Go, lovely Rose!

Tell her that wastes her time and mo.

That now she knows,

When I resemble her to thee,

How sweet and fair she secms to be.

Tell her that's young,

And shuns to have her graees spied.

That, hadst thou sprung

In deserts, where no men abide,

Thou must have uncommended diea.

Small is the worth

Of beauty from the light retired;

Bid her come forth,

Suffer herself to be desired,

And not blush so to be adnired. 
Then die! that she

The common fate of all things rare

May read in thee;

How small a part of time they share,

T'hat are so wondrous sweet and fair!

(Additional stanza by H. K. White.)

Yet, though thou fade,

From thy dead leaves let fragrance rise,

And teach the maid,

- jar Goodness, Time's rude hand defies,

And Virtue lives, when Beauty dies.

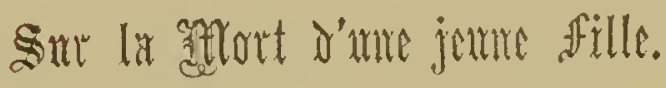

\section{Malesherbes.}

Elle etait de ee monde, où les plus belles ehoses

Ont le pire destin!

Et rose- s!le a véeu ee que vivent les roses-

L'espace d'un matin. 


\section{द⿱}

Mary Howitt.

'A ND where have you been, my Mary, And where have you been from me?' I've been to the top of the Caldon-Low, The Midsummer night to see!"

'And what did you see, my Mary; All up on the Caldon-Low?'

'I saw the blithe sunshine come down, And I saw the merry winds blow.'

'And what did you hear, my Mary, All up on the Caldon-Hill?'

'I heard the drops of the water made, And the green corn ears to fill.'

'Oh, tell me all, my Mary--All, all that ever you know; For you must have seen the fairies, Last night on the Caldon-Inow.' 
' Then take me on your knee, mother, And listen, mother of mine:

A hundred fairies danced last night, And the harpers they were nine.

' And merry was the glee of the harp-strings, And their dancing feet so small; But, oh, the sound of their talking Was merrier far than all l'

' And what were the words, my Mary, That you did hear them say?' 'I'll tell you all, my motherBut let me have my way!

'And some they played with the water, And rolled it down the hill; "And this," they said, "shall speedily turn, The poor old miller's mill;

"For there has been no water, Ever since the first of May; And a busy man shall the miller be By the dawning of the day!

"Oh, the miller; how he will laugh, When he sees the mill-dam rise! The jolly old miller, how he will laugh, Till the tears fill both his eyes !" 
'And some they seized the little winds,

That sounded over the hill,

And each put a horn into his mouth,

And blew so sharp and shrill :-

: And there." said they, "the merry winds go

Away from every horn;

And those shall clear the mildew dank

From the blind old widow's corn.

" Oh, the poor, blind old widow-

Though she has been blind so long,

She'll be merry enough when the mildew's gono,

And the eorn stands stiff and strong!"

' And some they brought the brown lintseed.

And flung it down from the Low-

"And this," said they, " by the sunrise,

In the weaver's croft shall grow!

"Oh, the poor, lame weaver,

How will he laugh outright,

When he sees his dwindling flax-field,

All full of flowers by night !"

'And then upspoke a brownie, With a long beard on his chin-

"I have spun up all the tow," said he,

" $\Delta$ nd I want some more to spin. 
"I've spun a piece of hempen cloth, And I want to spin another-

A little sheet for Mary's bed, And an apron for her mother!"

'And with that I could not belp but laugh, And I laughed out loud and free; And then on the top of Caldon-Low There was no one left but me.

'And all, on the top of Caldon-Low, The mists were cold and gray, And nothing I saw but the mossy stones That round about me lay.

'But as I eame down from the hill-top, I heard, afar below, How busy the jolly miller was, And how merry the wheel did go I

'And I peeped into the widow's field; And, sure enough, was seen The yellow ears of the mildewed corn All standing stiff and green.

'And down by the weaver's eroft I stole, To see if the flax was high; But I saw the weaver at his gate

With the good news in his eye I 
"Now, this is all I heard, mother,

And all that I did see;

So, prithee, make my bed, mother,

For I'm tired as I can be l'

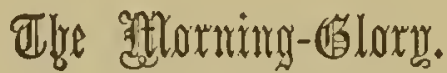

Maria Lowell.

WE wreathed about our darling's head the Morning-Glory bright;

Her little face looked out beneath, so full of life and light, So lit as with a sunrise, that we could only say,

She is the Morning-Glory true, and her poor types are they.

So always from that happy time we called her by their name, And very fitting did it seem, for, sure as Morning came, Behind her cradle-bars she smiled to catch the first faint ray, As from the trellis smiles the flower and opens to the day

But not so beautiful they rear their airy eups of blue, As turned her sweet eyes to the light brimmed with sleep's tender dew;

And not so close their tendrils fine round their supports are thrown,

As those dear arms whose outstretched plea clasped all hearts to her own. 
We used to think how she had eome, even as comes the flower, The last and perfect added gift to erown love's morning hour, And how in her was imaged forth the love we could not say, As on the little dew-drops round shines back the heart of dily.

We never could have thought, Oh God, that she muy. wither up,

Almost before a day was flown, like the Morning Glory's eup :

We never thought to see her droop her fair and noble heal, Till she lay stretched before our eyes, wilted, and cold, and dead.

The Morning-Glory's blossoming will soon be coming round, We sec their rows of heart-shaped leaves upspringing from the ground;

The tender things the winter killed renew again their birth. But the Glory of our Morning has passed away from earth.

Oh Earth, in vain our aching eyes streteh over thy greec plain;

Too harsh thy dews, too gross thine air her spirit to sustain,But up in groves of Paradise full surely we shall see Our Morning-Glory beautiful twine round our dear Lond'z knee 


\section{Afturself.}

H. E. G, Arey.

WELL, once I was a little girl,

A-dwelling far away;

My mother made the butter,

And my father made the hay.

And I-I wandered, out of school,

Amid the woodlands wild,

And scorned the tcacher's measured rulo-

A harum-scarum child.

Of thorny lanc, and meadow fair,

My frock bore token still;

The wind would catch my yellow hair,

And braid it at its will.

The sun was busy with my face-

And still it shows it some;

And, ou my neck, I know how high

My dresses used to come 
And I was smart, and all the springs On all the hills could show; And, if there were some grammar things I didn't eare to know,

I always knew how many boughs The latest tempest broke, And just how far the woodpecker Had girdled round the oak.

I knew the tree where slept the crows:

And, on the water's brim,

I climbed among the hemlock boughs,

To wateh the fishes swim.

I knew; beside the swollen rill,

What flowers to bloom would burst;

And where, upon the south-sloped hill,

The berries ripened first.

Each violet tuft, each cowslip green,

Each daisy on the lea,

I counted one by one-for they

Were kith and kin to me.

I knew the moles that dared to claim

'The vanished beavers' huts;

And sat on mossy logs to wateh

The squirrels crack their nuts: 
And they winked slyly at me, too, But never fled away,

For in their little hearts they knew That I was wild as they.

And always in the Winter, too,

Before the breakfast time,

I wandered o'er the erusted snow,

To hear the waters ehime.

To see how thick the ice had grown, And where the hasty spray

Its jewels o'er the shrubs had thrown In such a curious way.

And in a little cavern, where

The waters triekled through,

The shape of every icicle

That gemmed its sides I knew;

For there were hermits' huts, and towers, And eities grand and gay,

And Alpine peaks and tropie flowers, And fairer things than they:

For oft the sun eame glinting through The ehinks some iee lens spanned, And deeked in many a rainbow hue These seenes of fairy laud. 
And now, when to my roving brain

There starts some fancy, shrined

In tints more bright than earth can claim,

That cavern comes to mind.

When Winter to the Spring-tide wore, Through slumps and sloughs I strayed,

To list the splashing and the roar

The mountain torrents made.

Oh! that was glee; and oft I turned

In rapture from the shore,

And said (I know not where I learned)

The lines about "Lodore."

There was a well-filled garret, where

I hid on stormy days,

And built bright castles in the air,

And conned most ancient lays;

And through the snares that Scott has set,

For fancy roamed with joy,

Or, from some old and worn gazette,

I hacked the rhymes of "Roy."

In mouse-holes rare I hid with care

Those relics of the Muse,

And wondered who the Poets were

That scribbled for the News. 
Jsut when once more the skies were fair,

And I the woods could win,

For books and rhymes that charmed we there

I did not care a pin.

My mother saw my garments soiled,

And thought it hardly right;

But, when I wished to go again,

My father said I might.

And now I am a woman grown,

And strive to keep my hair

Beneath the guidance of my comb,

And bind my dress with care.

Through slumps and drifts I do not roam,

Nor climb the hemlock trees,

Nor hide 'mid colwebbed trunks at home-

For fear 'twill raise a breeze.

I thread the world's unchanging maze

Through all Life's fettered span,

And seek to be in all my ways

As "proper" as I can.

I never liked the ways of men,

Or wished more old to grow,

For life was wondrous curious then,

And isn't curious now. 
I know not how it secmed to me, Or what my father thought, But mother said I'd never be

A woman, as I ought.

I know 'tis bard such children wild

In polished rules to train; And, if I were once more a child, I'd_-do just so again.

\section{đlye fonntain.}

TNO the sunshine,

Full of the light,

Leaping and flashing

From morn till night.

Into the moonlight,

Whiter than snow,

Waving so flower-like,

When the winds blow.

Into the starlight

Rushing in spray,

Happy at midnight,

Happy by day. 
Ever in motion,

Blithesome and cheery,

Still climbing heavenward,

Never a-weary.

Glad of all weathers,

Still seeming best;

Upward or downward,

Motion thy rest.

Full of a aatura

Nothing can tame,

Changed every moments

Ever the same.

Ceascless aspiring,

Ceaseless content,

Darkness or sunshine

Thy element.

Glorious Fountain!

Let my heart be

Fresh, changeful constans.

Upward like thee. 


\section{Somg of the difowor Alngels.}

Mrs. Hale.

$W^{\mathrm{E}}$ tend the flowers of every hue,

But love the red, the white, the blue-

Red, and white, and blue;

The red is Love's sweet blushing hue,

And white is fair as Faith to view,

And Truth is imaged in the blue-

Red, and white, and blue;

Where Faith is free, and Love is true,

We sow the red, and white, and blue.

In Eastern lands the seed we east,

But thorns would choke, or mildew blast,

Red, and white, and blue;

Sweet Love was lost in Passion's fires-

From idol-worship Faith retires-

And 'Truth by despot's power expires,-

Red, and white, and blue-

All faded, perished, where they grew,

The flowers of red, and white, and bluo. 
Then to the Western World we eame,

And sowed the flowers of boly name-

Red, and white, and blue.

Love, and Faith, and Truth, were sown -

And oh! how strong the plants are grown!

And o'er the earth the flowers are strown,

Red, and white, and blue;

For Freedom, eagle-pinioned, flew,

To bear the red, and white, and blue.

Now in a banner, fair to see,

The hues are twined in Trinity,

Red, and white, and blue:

The red and white, like flowers of light, And stars, as seeds, the blue bedight;

And o'er the world this banner bright,

Red, and white, and blue-

Shall have a guard of angels true,

Who love the red, and white, and blus. 


\section{attorning.}

Caroline A Brigga

\section{WAT shall I call thee
My Blossom, my Flower}

How shall I name thee,

Thou pride of my bower?

My Lily, my Tulip,

My beautiful Rose-

The fairest and sweetest

Around me that glows I

Come nearer, my Violet,

Nearer my side;

My Primrose, my Heart's Easo.

My gay London-Pride.

My darling Aeacia,

My Blue-Bell, my Pink !

My Foxglove, my Hawthorn-

What else!-let me think!

My Jasmine, my Jonquil, My Cowslip, my Sage,

My sweet-scented Clover,

My Youth, and-Old Agal 
My golden Laburnum-

(I've finished my store,

Yet tarry a moment,

I'll think of some moro.)

Come! let me clasp thy hand

Warmly in mine,

My glowing Nasturtian,

My sweet Columbine.

Sing to me softly,

My Calla, my Balm!

I.et our voices ascend

In a sweet morning psalm.

Rouse thee, my Dahlia,

I'm waiting thee long I

Ah, wherefore compel mo

To sigh for thy song!

liut-would you believe it?

She's slumbering fast !

She's nothing at all

But a Poppy, at last I 


\section{OOde to Ge Genting.}

Collins.

F aught of oaten stop or pastoral song,

1 May hope, ehaste Eve, to soothe thy modest ear,

Like thy own brawling springs,

Thy springs, and dying gales;

O Nymph reserved, while now the bright-hair'd sun Sits in you western tent, whose eloudy skirts,

With brede ethereal wove,

O'erhang his wavy bed:

Now air is hush'd, save where the weak-eyed bat,

With short shrill shriek flits by on leathern wing,

Or where the beetle winds

His small but sullen horn,

As oft he rises 'midst the twilight path,

Against the pilgrim borne in hecdless hum;

Now teach me, maid eomposed,

To breathe some soften'd strain, 
Whose numbers stealing through thy darkening vale May not unscemly with its stillness suit

As, musing slow, I hail

Thy genial, loved return!

For when thy folding-star arising shows

His paly circelet, at his warning lamp

The fragrant Hours and Elves

Who slept in buds the day,

And many a Nymph who wreathes her brows wit] sedge, And shicus the freshening dew, and, lovelier still,

The pensive Pleasures sweet

Prepare thy shadowy car.

Then let me rove some wild and heathy scene,

Or find some ruin 'midst its dreary dells,

Whose walls more awful nod

By thy religious gleams.

Or if chill blustering winds, or driving rain,

Prevent my willing fect, be mine the hut,

That from the mountain's side,

Views wilds, and swelling floods,

And hamlets brown, and dim-discover'd spires, And hears their simple bell, and marks, o'er all,

Thy dewy fingers draw

The grarlual dusky veil. 
While Spring shall pour his showers, as oft he wont, And bathe thy breathing tresses, meekest Eve!

While Summer loves to sport

Beneath thy lingering light:

While sallow Autumn fills thy lap with leaves,

Or Winter yelling through the troublous air,

Affrights thy shrinking train,

And rudely rends thy robes:

So long, regardful of thy quiet rule,

Shall Fancy, Friendship, Scicnce, smiling Peace,

Thy gentlest influence own,

And love thy favorite nomo. 


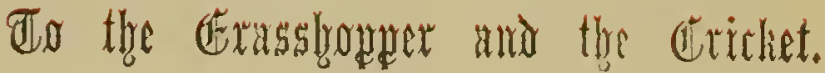

\section{Anom.}

GREEN little vaulter in the sunny grass, Catehing your heart up at the feel of June, Sole voice that's heard anidst the lazy noon, When even the bees lag at the summoning brass; And you. warm little housekecper, who class

With those who think the candles come too soon, Loving the fire, and witl your tricksome tunc, Nick the glad, silent moments as they pass;

$O$ sweet and tiny cousins, that belong Oue to the fields, the other to the hearth. Both have your sunshine; both, though small, are strong It your clear hearts; and both scem given to carth Po sing in thoughtful ears this natural songIn doors and out, summer and winter-Mirth. 


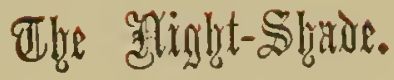

[TREAD aside from my starry bloom I

1 I am the nurse, who feeds the tomb

(The tomb, my child)

With dainties piled,

Until it grows strong as a tempest wild I

Trample not on a virgin flower!

I am the maid of the midnight hour ;

I bear sweet sleep,

To those who weep,

And lie on their eyelids dark and deep.

Tread not thou on my snaky eyes!

I am the worm that the weary prize,

The Nile's soft asp,

That they strive to grasp,

And one that a Queen has loved to clasp I 
THE STAR AND THE WATER-L:LY.

Pity me! I am she, whom man,

Hath hated since ever the world began;

I soothe his brain,

In the night of pain,

But at morning he waketh,_-and all is vain!

Whe Stat auro the gaenter-apilty.

Oliver Wendell Holmes.

THE Sun stepped down from his golden throne,

And lay in the silent sea;

And the Lily had folded her satin leaves,

For a sleepy thing was she;

What is the Lily dreaming of?

Why crisp the waters blue?

See-see, she is lifting her varnished lid

Her white leaves are glistening through.

The Rose is cooling his burning cheek

In the lap of the breathless tide;-

The Lily hath sisters fresh and fair,

That would lie by the Rose's side.

He would love her better than all the rest,

And he would be fond and true;

But the Lily unfolded her weary lids

And looked at the sky so blue. 
Remember, remember, thou silly one, How fast will thy Summer glide, And wilt thou wither a virgin pale, Or flourish a blooming bride? " $O$ the Rose is old, and thorny and eold, And he lives on Earth;" said she, "But the Star is fair, and he lives in the air, And he shall my bridegroom be."

But what if the stormy eloud shall come, And ruffle the silver sea?

Would he turn his eye to the distant sky

To smile on a thing like thee?

O no, fair Lily, he will not send

One ray from his far-off throne;

The winds shall blow and the waves shall flow, And thou wilt be left alone.

There is not a leaf on the mountain top. Nor a drop of evening dew, Nor a golden sand on the sparlsling shore.

Nor a pearl on the waters blue,

That he has not eheered with his fickle smile And warmed with his faithless beamAnd will he be true to a fallid flower, . That floats on the quiet strean? 
Alas, for the Lily! she would not heed,

But turned to the skies afar;

And bared her breast to the trembling ray

That shot from the rising star.

The eloud eame over the darkened sky,

And over the waters wide;

She looked in vain through the the beating rain

And sunk in the stormy tide.

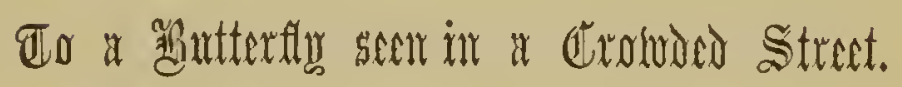

William Pitt Palmer.

WHEREFORE, little fluttering thing,

With the rainbow-tinted wing,

And the right. at will, to rove

Sunny lawn or shadowy grove,

Hast thou left demesnes so blest,

To be Babel's wretehed guest?

Here's no fitting haunt for thee,

Boon eompanion of the bee!

Born, like her, with flowers to dwell

In the sweet sequestered dell,

Aud at nature's board to sip

Neetar from eaeh blossom's lip.

Here, where 'neath man's iron tread

Earth's green beauties all are dead, 
Thou wilt find no leafy screen

From the noontide's piereing sheen,

And at eve no fairy home,

Like the lily's golden dome.

Here, where hunger's eager pain

Pleads at plenty's door in vain,

Or, if heard, too often must

Feel the seorn that flings the erust,

Thou, gay rover, searce shalt find

Chartered feast or weleome kind;

For if man to man's austere,

What hast thou to hope for here?

Haste thee, then, where skies are farr,

Fresh as Spring's the Summer air,

Bright as tears affeetion sheds,

Dews that gem the violet beds,

Pure as morn the perfumed breeze,

Sweet the sylvan melodies,

Soft the glow o'er hill and glade,

Cool their very noontide shade,

And where all of earth and air

Freely nature's banquets share!

Hold thee, now ! the bright-winged cries;

Cease thy rural rhapsodies, Till I briefly tell thee why

Hither I eame daneing by.

Scest thou all the vista gay

Thronged with fashion's proud array? 
Tinted silks, like Autumn trees,

Waving brightly in the breeze?

Plume and wreath of varied dyes,

Rich as sunset's glowing skies?

Ruby, pearl, and emerald green

Basking in the diamond's sheen?

These are but my liveried pride,

Tints and tinsel magnified;

And where gaud and glare abound,

May not nature's belle be found?

Mark again the motley throng

By thy side that sweeps along,

With so gay and smiling guise

One might gaze with wondering eyes,

For some sphered Elysium near,

Whence such shapes had lighted hero:

Born when fortune's starry eope

Cast its brightest horoscope,

Hcirs of leisure, wealth, and will,

How should they their end fulfil,

But by idlesse, faney, show,

As we rural minions do?

Whom thcy sometimes deign to visit,

And both rhyme and reason is it,

That we too should not eontemn

In our turn to visit them,

Nor ourselves unweleome see

Where our kith and kindred be I 


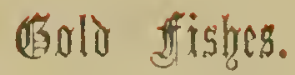

Hartley Coleridg\%.

R ESTl.ESS forms of living light,

Cheating still the curious sight

With a thousand shadowings,

Various as the tints of even,

Gorgeous as the hues of heaven,

Reflected on your native streams

In flitting, flashing; billowy gleams

Harmless warriors clad in mail

Of silver breast-plate, golden scale;

Mail of Nature's own bestowing,

With peaceful radiance mildly glowing,

Keener than the Tartar's arrow,

Sport ye in your sea so narrow,

Was the sun himself your sire?

Were ye born of vital fire!

Or of the shade of golden fiowers,

Such as we fetch from Fasteru bowers,

To mock this murky clime of ours? 
Upwards, downwards, now ye glance, Weaving many a mazy danee,

Seeming still to grow in size, When ye would elude our eyes.

Pretty ereatures! we might deem

Ye were happy as ye scem,

As gay, as gamesome, and as blithe, As light, as loving: and as lithe, As gladly earnest in your play, As when ye gleamed in fair Cathay; And yet, sinee on this hapless earth There's small sineerity in mirth, And laughter oft is but an art To drown the outery of the heart, It may be that your eeaseless gambols, Your wheelings, dartings, drivings, rambles,

Your restless rovings round and round The eireuit of your crystal bound, Is but the task of weary pain, An endless labor, dull and vain; And while your forms are gayly shiniug. Your little lives are inly piniug! Nay! but still I fain would dream That ye are happy as ye seem. 


\section{Sonnet.}

\section{Shakspeare.}

THE forward Violet thus did I chide;--

Sweet thief, whence didst thou steal thy sweet that smells, If not from my Love's breath? The purple pride

Which on thy soft check for complexion dwells,

In my Love's veins thou hast too grossly dyed.

The Lily I condemnéd for thy hand,

And beds of Narjoram had stolen thy hair:

The Roses fearfully on thorns did stand:

One blushing shame, another white despair;

A third, nor red, nor white, had stolen of both,

And to his robbery had annexed thy breath;

But for his theft, in pride of all his growth

A vengeful canker ate him up to death.

More flowers I noted, yet I none could see,

But sweet or color it had stolen from thee. 


\section{\$ubbatty estoning.}

$$
\text { Georgr D. Frentice. }
$$

"TIS holy time. The evening siade

1 Steals with a soft control

O'er nature, as a thought of heaven

Steals o'er the human soul.

And every ray from jonder blue,

And every drop of falling dew,

Scem to bring down to human woes

From Heaven a message of reposc.

O'cr yon tall rock, the shady trecs
A solemn group incline,

Like gentle nuns in sorrow bowed Around their holy shrine;

And o'cr them now the night-winds blow

So calm and still, the music low;

Seems the mystcrious voice of prayer

Soft echoed on the evening air. 
The mists, like incense from the earth, Rise to a God beloved,

And o'er the waters move, as erst

'The Holy Spirit moved:

The torrent's voice, the waves' low hymu,

Seem the fair notes of Seraphim;

And all earth's thousand voices raise

Their song of worship, love, and praise.

The gentle sisterhood of flower's

Bend low their lovely eyes,

Or gaze through trembling tears of dew

Up to the holy skies;

And the pure stars come out abore

Like sweet and blessed things of love,

Bright signals in the ethereal domo

To guide the parted spirit home.

There is an air of blessedness

In air and earth and heaven, And Nature wears the blessed look

Of a young saint forgiven:

Oh who, at such an hour of love,

Can gaze on all around, abore,

And not kneel down upon the sod

With Nature's self, to worship God! 


\section{gedtrite 嗮oses.}

Sarah Lcuisa P. Smith.

THEY were gathered for a bridall

1 I knew it by their hue:

Fair as the Summer moonlight

Upon the slecping dew.

From their fair and fairy sisters

They were borne, without a sigh,

For one remembered evening,

To blossom and to dic.

They were gathered for a bridal!

And fastened in a wreath;

But purer were the Roses

Than the heart that lay beneath;

Yet the beaming eye was lovely,

And the coral lip was fair,

And the gazer looked, and ask'd not

For the secret hidden there. 
They were gathered for a bridal I

Where a thousand torches glistened;

When the holy words were spoken,

And the false and faithless listened,

And answered to the vow

Which another heart had taken;

Yet he was present then,

The once loved, and the forsaken.

They were gathered for a bridal!

And now, now they are dying,

And young Love at the altar

Of broken faith is sighing.

Their Summer life was stainless, And not like hers who wore them;

They are faded, and the farewell

Of beauty lingers o'er them!

\section{The apilly.}

J. G. Percival.

T HAD found out a sweet green spot,

Where a Lily was blooming fair;

The din of the city disturbed it not, But the spirit, that shades the quiet cot

With its wings of Love, was there. 


\section{I found that Lily's bloom}

When the day was dark and chill:

It smiled, like a star in the misty gloom,

And it sent abroad a soft perfume,

Which is floating arouud me still.

I sat by the Lily's bell,

And watched it many a day:-

The leaves, that rose in a flowing swell,

Grew faint and dim, then drooped and fell, And the flower had flown away.

I looked where the leaves were laid In withering paleness, by, And, as gloomy thoughts stole on me, said, There is many a sweet and blooming maid, Who will soon as dimly die. 
帮ctition for an dosolute actreat.

Countess of Winchelsea
CIVF me, 0 indulgent Fate!
$\checkmark$ Give me yet, before I die,
A sweet, but absolute retreat
'Mongst paths so lost, and trees so high,
That the world may ne'er invade,
Through sueh windings and such shade,
My unshaken liberty.

No intruders thither come!

Who risit, but to be from home;

None who their vain moments pass,

Only studious of their glass;

News, that charm to list'ning ears,

That false alarm to hopes and fears,

That common theme for every fop,

From the statesman to the shop,

In those coverts ne'er be spread,

Of who's deceas'd, or who's to wed, 
Be no tidings thither brought,

But silent as a midnight thought,

Where the world may ne'er invade,

Be those windings and that shade.

Give me there (since Heaven has shown

It was not good to be alone)

A partner suited to my mind,

Solitary, pleas'd and kind;

Who, partially, may something see

I'referr'd to all the world in me;

Slighting by my humble side,

Fame and splendor, wealth and pride.

When but two the earth possest,

'Twas their liappiest days and best;

They by bus'ness, nor by wars,

They by no domestie eares,

From each other e'er were drawn,

But in some grove, or flow'ry lawn,

Spent the swiftly flying time,

Spent their own and nature's prime,

In love; that only passion given

To perfeet man, whilst friends with Heaven

Rage and jealousy and hate,

Transports of his fallen state

(When by Satan's wiles betray'd),

Fly those windings, and that shade! 
Thus from crowds and noise remov'd

Let each moment be improv'd;

Every object still produce,

Thoughts of pleasure, and of use.

When some river slides away,

To increase the boundless sea;

Think we then, how time does haste,

To grow eternity at last.

By the willows, on the banks,

Gathered into social ranks,

Playing with the gentle winds,

Straight the boughs, and smooth the rinds,

Noist each fibre and each top,

Wearing a luxurious crop,

Let the time of youth be shown,

The time, alas 1 too soon outgrown

Whilst a lonely stubborm oak,

Which no breezes can proroke,

No less gusts persuade to move,

Than those, which in a whirlwind drove,

Spoil'd the old paternal feast,

And left alive but one poor guest.

Rivell'd the distorted trunk,

Sapless limb, all bent and shrunk,

Sadly does the time presage,

Of our too near approaching age. 
Let me then, indulgent Fate,

Let me still, in my retreat,

From all roving thoughts be freed,

Or aims, that may contentions breed;

Nor be my endeavors led

By goods, that perish with the dead!

Fitly might the life of man

Be indeed esteem'd a span,

If the present moment were

Of delight his only share;

If no other joys he knew

Than what round about him grew.

But as those, who stars would trace

From a subterranean place,

Through some engine lift their eyes

To the outward, glorious skies;

So the immortal spirit may,

When descended to our elay,

From a rightly govern'd frame

View the height, from whence she came,

To her paradise be eaught,

And things unutterable taught.

Give me then, in that retreat,

Give me, $\mathrm{O}$ indulgent Fate!

For all pleasures left behind,

Contemplations of the mind.

Let the fair, the gay, the vain

Courtship and applause obtain; 
Let the ambitious rule the earth;

Let the giddy fool have mirth;

Give the epieure his dish,

Ev'ry one their sev'ral wish;

Whilst my transports I employ

On that more extensive joy,

When all heaven shall be surveyed

From those windings and that shado.

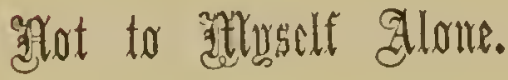

Anon

"NOT to myself alone,"

1. The little opening flower transported cries;

"Not to myself alone I bud and bloom; With fragrant breath the breczes I perfume, And gladden all things with my rainbow dyes; The bee comes sipping, every eventide,

His dainty fill;

The butterfly within my cup doth hide

From threatening ill." 
"Not to myself alone,"

The cireling star with loonest pride-

"Not to myself alone I rise and set;

I write upon night's coronal of jet

II is power and skill who formed our myriad host

$\Lambda$ friendly beacon at heaven's open gate,

I gem the sky,

That man might ne'er forget, in every fate,

His home on high."

"Not to myself alone,"

The lieavy-laden bee doth murmuring hum-

". Not to myself alone from flower to flower

I rove the wood, the garden and the bower,

And to the hive at evening weary eome:

For man, for man the luseious food I pile

With busy eare,

Content if this repay my eeaseless toil-

A scanty share."

"Not to myself alone,"

The soaring bird with lusty pinion sings-

"Not to myself alone I raise the song;

I cheer the drooping with my warbling tongue:

And bear the mourner on iny viewless wings;

I bid the hymnless ehurl my anthem learn,

And God adore;

I eall the worldling from his dross to turn,

And sing and sour." 
"Not to myself alone,"

The streamlet whispers on its pebbly way-

"Not to myself alone I sparkling glide;

I scatter life and health on every side,

And strew the fields with herb and flow'ret gay;

I sing unto the common, bleak and bare,

My gladsome tume;

I sweeten and refresh the languid air

In droughty June."

"Not to myself alone-"

Ol man, forget not thou, earth's honorcd priest! Its tongue, its soul, its life, its pulse, its heartIn earth's great chorus to sustain thy part.

Chiefest of guests at life's ungrudging feast, Play not the niggard, spurn thy native elod, And self disown;

Live to thy neighbor, live unto thy God, Not to thyself alone. 


\section{sptring in the lap of acetinter.}

Anon

THE mist still hovers round the distant hills;

But the blue sky above us has a elear

And pearly softness; not a white speek lies

Upon its breast; it is a erystal dome.

There is a quiet eharm about this morn

Which sinks into the soul. No gorgeous eolors

Has the undraperied earth, but yet she shows

A vestal brightness: not the voiee is heard

Of sylvan melody; whether of birds

Intent on song; or bees mingling their music

With their keen labor; but the twittering voice

Of ehaffinch, and the wild unfrequent note

Of the lone woodlark, and the minstrelsy

Of the blest robin, liave a potent spell

Chirping away the silence; not the perfume

Of violets scents the gale, nor apple-blossom,

Nor satiating bean-flower; the fresh breeze

Itself is purest fragranee. Light and air

Are ministers of gladness; where these spread,

Beauty abides, and joy: where'er Life is

There is no melaneholy. 


\section{artadian a}

R. H. Stoddard.

COME, all ye virgins fair in kirtles white,

Ie debonair and merry-liearted maids,

Who have been out in troops before the light,

And gathered blossoms in the woodland shades, -

The foot-prints of the fiery-sandalled day

Are glowing in the sky like kindling coals,

The elouds are golden rimmed like burning scrolls,

Jagged and fringed, and darkness melts away;

The shrine is wreathed with leaves, the holy urns

Brimming with morning dew are laid thereby,

The censers swing, the odorous incense burns,

And floats in misty volumes up the sky;-

Lay down your garlands and your baskets trim,

Heaped up with floral offerings to the brim,

And knit your little hands, and trip away

With light and nimble feet

To music soft and sweet,

And eelebrate the joyous break of day,

And sing a liymn to Flori, Queen of May. 
Ol, Flora, sweetest Flora, goddess bright,

Impersonation of selectest things,

The soul and spirit of a thousand springs Bodied in all their loveliness and light,

A delicate ereation of the mind,

Fashioned in its divinest, daintiest mould,

In the bright age of gold,

Before the world was wholly lost and blind, But saw and entertained with thankful heart

The gods as guests,-O Oh Flora, goddess dear, Immaeulate, immortal as thou art,

Thou wert a maiden onee, like any here, And thou didst tend thy flowers with proper care, And shield them from the sun and ehilly air, Wetting thy little sandals through and through, As all flower-maidens must in morning dew, Roving among the urns and mossy pots, About the hedges and the garden plots, Straightening and binding up the drooping stalks That kissed thy sweeping garments in the walks, Setting thy dibble deep and sowing seeds, And eareful-lianded plueking out the weeds, A simple flower-girl, and lowly born,

Till Zephyr bore thee to the heavens away;And thus it was, - Hying one pleasant morn

Behind the golden ehariot of the day, Sighing anid the winged laughing Hours, In love with something bright which haunted him, Sleeping on beds of flowers in arbors dim, 
Breaking his tender heart with love extreme, He saw thee on the earth and thy flowers, The spirit of his dream!

Entraneed with longings deep he called the air, And melting bodiless in the warm, sweet South, Twined his invisible fingers in thy hair, And, stooping, kissed thee with his odorous mouth, And chased thec fying in thy garden shades, And wooed, as men are wont to woo the maids, And won at last, and then flew back to heaven, Pleading with Jore till his eonsent was given, And thou wert made immortal,--happy day !The goddess of the flowers and Queen of May!

Oh Flora, sweetest Flora, hear us now,

Gathered to worship thee in shady bowers;

Accept the benediction and the vow

We offer thee that thou hast spared the flowers;

The Spring has becn a cold belated one,

Dark elouds and showers, and a little sun, And in the nipping mornings, hoary frost; We hoped, but feared the tender secds were lost, But, thanks to thee, at last they 'gan to grow, Pushing their slender shoots above the ground In eultured gardens trim, and some wore found Beside the edges of the banks of snow.

Like spring-thoughts in the heart of Winter old, Or childreu laughing o'er a father's mould. 
And now the sward is full and teems with more, Earth never was so bounteous before;

Here are red roses, throwing baek their hoods

Iike willing maids, to greet the kissing wind;

And here are violets from sombre woods,

With tears of dew within their lids enshrined,

I ilies like little maids in bridal white,

Or in their burial garments if you will;

And here is that bold flower, the daffodil,

That peers i' th' front of March, and daisics bright,

The restals of the morn, and eroeuses,

Snow-drops, like speeks of foam on stormy seas,

And yellow buttereups that gem the fields,

Like studs of riehest gold on massive shields,

Anemones that sprang in golden years,

(The story goes, they were not seen before,)

Where young Adonis, tusked by the boar,

Bled life away, and Venus rained her tears-

(Took! in their hearts a small ensanguined spot!)

And here is pansy and forget-me-not,

And trim Nareissus, vain and foolish elf,

Enamoured (would you think it?) of himself,

Rooted beside a erystal brook, his glass!

And drooping Hyaeinthus, slain, alas!

By rudest Auster, blowing in the stead

Of Zephyrus, then in Flora's meshes bound,

Pitehing witl bright Apollo in his ground

He blew the diseus back and struek hin dead!

Pied wind-flowers, oxlips, and the jessamine, 
The sleepy poppy and the oglantine, Prinlroses, Dian's flowers that ope at night, And here's that little sun, the marigold, And fringed pinks, and water lilies, bright

As floating naiads in the river eold; Carnations, gilliflowers, and savory rue, And rosemary that loveth tears for dew, And many rameless flowers and pleasant weeds That grow untended, in the marshy meads Where flags shoot up and ragged grasses wave Perennial, when autumn seeks her grave Anong the withered leaves; and breezes blow A dirge, and winter weaves a shroud of snow. Flowers! oh what loveliness there is in flowers!

What food for thought and faney rieh and new !

What shall we liken or eompare them to?

Stars in this trodden firmament of ours ;

Jewels and rare mosaies, dotting o'er

Creation's tessellated palaee floor ;

Or beauty's dials, marking with their leaves The pomp and flight of golden morns and eves; Illuminate missals open on the meads, Bending with rosaries of dewy beads;

Or charaeters inseribed on nature's serolls,

Or sweet thoughts from the leart of mother earth;

Or wind-roeked eradles, where the bees in rolls

Of odorous leaves are wont to lie in mirth,

Full-hearted, murmuring the hours away

Like little ehildren busy at their play; 
Or cups and beakers of the buttertlies, Brimming with nectar; or a string of bells Tolling unleard a requiem for the hours! Or eensers swinging incense to the skies;

Pavilions, tents, and towers,

The little fortresses of insect powers, Winding their horns withiu; or magic eells, Where little firies dream the time away, Niglit clfins slumbering all a summer's day;

Swcet nurshings thou art wont to feed with dew From ont thy urns, replenished in the blue.But this is idlesse all !-away! away!

White harded maids, and scatter buds around, And let the lutes awake and tabours sound, And crery heart its due devotion pay.

Ouce more we thank thee, Flora. and onee more

Perform our rites, as we were used to do.

Oh bless us, smile upon us, fair and true, And watch the flowers till summer's reign is o'er ; Preserve the seeds we sow in winter time From burrowing moles, and blight, and icy rime, And in their season eause the shoots to rise, And malse the dainty buds unseal their eyes, And we will pluek the finest, and entwine Chaplets; and lay them on thy rural shrine, And sing our choral hymns, melodious, sweet, And dance with nimble feet, And worship thee as now, serenely gay The goddess of the flowers and Queen of May I 


\section{Elowets.}

H. W. Longfeilono.

SPAKE full well, in language quaint and olden,

One who dwelleth by the eastled Rhine,

When he ealled the flowers, so blue and golden,

Stars that in earth's firmament do shine.

Stars thoy are, wherein we read our history,

As astrologers and seers of eld;

Yet not wrapped about with awful mystery,

like the burning stars whieh they beheld.

$\mathbf{W}^{\top}$ ondrous truths, and manifold as wondrous, God hath written in those flowers above;

But not less in the bright flowerets under us Stands the revelation of his love.

Bright and glorious is that revelation,

Written all over this great world of ours,

Making evident our own creation,

In these star's of earth-these golden flowers. 
And the poet, faithful and far-seeing, Sees, alike in stars and flowers, a part Of the self-same, universal being Which is throbbing in his brain and heart.

Gorgeous flowerets in the sun-light shining, lilossoms flaunting in the eye of day, Tremuluus leaves, with soft and silver lining, Buds that open ouly to decay.

Brilliant hopes, all woven in gorgeous tissues, Flaunting gayly, in the golden light; Iatrge desires, witl most uncertain issues; Teuder wishes, blossoming at night!

These in flowers and men are more than seeming, Workings are they of the self-same powers, Wlich the poct, in no idle dreaming, Seeth in himself, and in the flowers.

Every where about us they are glowing;

Some like stars, to tell us Spring is born; Others, their blue eyes with tears o'erflowing, Stand like Ruth amid the golden corn.

Not a'one in Spring's armorial bearing, And in Sunmer's green-emblazoned field, But in arms of brave old Autunn's wearing, In the centre of his brazeu shield; 
Not alone in meadows and green alleys, On the mountain-top and by the brink Of the sequestered pools in woodland ralleys, Where the slaves of Nature stoop to drink;

Not alone in her vast dome of glory, Not on graves of bird and beast alone, But in old cathedrals, high and hoary, On the tombs of heroes, carved in stone;

In the cottage of the rudest peasant, In ancestral homes, whose erumbling towers, Speaking of the Past unto the Present, Tell us of the ancient games of Flowers.

In all places, then, and in all seasons, Flowers expand their light and soul-like wings, Teaehing us, by most persuasive reasons, How akin they are to human things.

And with ehildlike, eredulous affection, We behold their tender buds expand; Emblems of our own great resurrection; Emblems of the bright and better land. 


\section{Eatly afllowintr.}

Miss A. E. Starr.

$\mathrm{O}^{\mathrm{H} \text { waning moon, that with diminished horn }}$ Now mak'st thy tardy exit from the sky, And with thy mournful and complaining ey Art saddening all the beauty of the morn, I hasten from a presenee so forlorn,

Nor e'ur will emblem tind, when most I sigh, For love so dear as mine, in aught so wry As thy wan aspeet at this eheerful dawn. But waning now, the sooner wilt thou sail In nobler lustre and of ampler size. The sooner o'er the budding forests rise With that sweet light whieh lovers inly hail; And thus, sad moon, when most thou art apric, Thou hast a promise for my hopeful eycs. 


\section{Song in 䬲raise of Sptring.}

\section{Barry Cormoall.}

\section{WHEN the wind blows}

In the sweet rose-tree,

And the cow lows

On the fragrant lea,

And the stream flows

All bright and free,

'Tis not for thee, 'tis not for me;

"Tis not for any one here, I trow:

The gentle wind bloweth,

The happy cow loweth,

The merry stream floweth,

For all below!

Oh, the Spring! the bountiful Spring!

She shineth and smileth on every thing!

Where eome the sheep?

To the rich man's moor.

Where cometh sleep?

To the bed that's poor. 
Peasants must weep,

And kings endure;

That is a fate that none can cure !

Yet Spring does all she can, I trow:

She brings the bright hours,

She weaves the sweet flowers,

She dresseth her bowers,

For all below!

Oh, the Spring! the bountiful Spring!

She shineth and smileth on every thing!

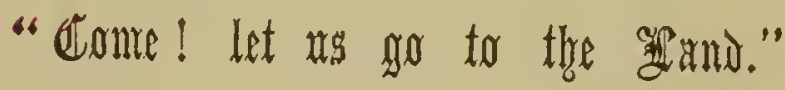

Barry Cornwall.

COME;-let us go to the land

Where the violets grow!

Let's go thither hand in hand,

Over the waters and over the snow,

To the land where the sweet, sweet violets blow I

There,-in the beautiful south,

Where the sweet flowers lie,

Thou shalt sing; with thy sweeter mouth,

Under the light of the evening sky,

That Love never fades, though violets die ! 


\section{actlartb.}

$$
\text { W. } \curvearrowright \text { Bryaute. }
$$

TWHE stormy March is come at last,

1 With wind, and cloud, and changing skies;

I bear the rushing of the blast

That through the snowy valley flies.

Ah! passing few are they who speak,

Wild, stormy month, in praise of thee;

Yet, though thy winds are loud and bleak,

Thou art a welcome month to me.

For thou to northern lands again

The glad and glorious sun doth bring, And thou hast joined the gentle train, And wear'st the gentle name of Spring.

And in thy reign of blast and storm, Smiles many a long, bright, sunny day, When the changed winds are soft and warm, And heaven puts on the blue of May. 
Then sing aloud the gushing rills

And the full springs, from frost set free,

That, brightly leaping down the hills,

Are just set out to meet the sea.

The year's departing beauty hides

Of wintry storms the sullen threat;

But in thy sternest frown abides

A look of kindly promise yet.

Thou bring'st the hope of those calm skies; And that soft time of sunny showers, When the wide bloom on earth that lies, Seems of a brighter world than ours. 


\section{A Suring Sontr.}

Eiduard Yoss?

I AUD the first Spring daisies;

Chant aloud their praises;

Send the children up

To the high hill's top:

Tax not the strength of their young hands

To inerease your lands.

Gatler the primroses;

Make handfuls into posies;

Take them to the little girls who are at work in mills :

Pluek the violets blue,-

Ah, pluek not a few!

Knowest thou what good thoughts from Heaven the violet instils?

Give the ehildren holidays,

(And let these be jolly days,)

Grant freedom to the children in this joyous Spring .

Better men, hereafter,

Shall we have, for laughter

Freely shouted to the woods, till all the cchus ring. 
Send the ehildren up

To the high hill's top,

Or deep into the wood's reeesses,

To wo Spring's caresses.

See, the birds together,

In this splendid weather,

Worship God,-(for he is God of birds as well as men ;) And each feathered neighbor

Enters on his labor, -

Sparrow, robin, redpole, finch, the linnet and the wren.

As the year advanees,

Trees their naked branches

Clothe, and seck your pleasure in their green apparel.

Insect and mild beast

Keep no Lent, but feast;

Spring breathes upon the carth, and their joy is increased. And the rejoicing birds break forth in one loud earol.

Al, eome, and woo the Spring;

List to the birds that sing;

Pluck the primroses; pluck the violets;

Pluck the daisies,

Sing their praises;

Friendship with the flowers some noble thought begets.

Come forth and gather these sweet elves,

(More witehing are they than the fays of old,)

Come forth and gatlier them yourselves,

Learn of these gentle flewers, whose worth is more than gold 
Come, eome into the wood ;

Pieree into the bowers

Of these gentle flowers,

Which not in solitude

Dwell, but with each other keep society;

And, with a simple piety,

Are ready to be woven into garlands for the good.

Or, upon summer earth,

To die, in virgin worth,

Or to be strewn before the bride,

And the bridegroom, by her side.

Come forth on Sundays;

Come forth on Mondays;

Come forth on any day;

Children, eome forth, to play :-

Worship the God of Nature in your ehildhood;

Worship Him at your tasks with best endeavor;

Worship Him in your sports; worship Him ever:

Worship Him in the wildwood;

Worship ITin amidst the flowers;-

In the green-wood bowers;

Pluck the buttercups, and raise

Your roiees in $H$ is praise. 


\section{The force of the 6rass.}

Anonymous.

HER I come ereeping, ereeping every where:

By the dusty roadside,

On the sunny hillside,

Close by the noisy brook,

In every shady nook,

I come ereeping, ereeping every where.

All around the open door,

Where sit the aged poor,

Here where the ehildren play,

In the bright and inerry May,

I come ereeping, creeping every where.

In the noisy eity street,

My pleasant face you'll meet,

Cheering the siek at heart,

Toiling his busy part,

Silently rreeping, creeping every where. 
You eannot see me coming,

Nor hear my low sweet humming;

For in the starry night,

And the glad morning light,

I come quietly ereeping every where.

More weleome than the flowers,

In Summer's pleasant hours;

The gentle erow is glad,

And the merry bird not sar

To see me ereeping, ereeping every whare.

When you're numbered with the dead,

In your still and narrow bed,

In the happy Spring I'll eome,

And deek your silent home;

Creeping, silently ereeping, every where.

My humble song of praise,

Most gratefully I raise

To Him at whose eommand

I beautify the land;

Creeping, silently ereeping, every where. 


\section{flutures.}

THERE are flowers rouud about mo

As I sit bencath the lime;

Sweet lowly things are breathing

The breath of olden time.

They look so kindly upward,

I greet them as iny friends;

And my mind to each small blossom

Such holy beauty lends,

That, as if to living creatures,

Where'er my glanee may fall,

On the blue-bells or the daisies,

I say, "God bless you all !"

Go forth, my little daughter,

The mid-day heat is o'er,

Qo forth among the flowers,

And gather thee a store. 
The little fairy Speedwell, With its many eyes of blue, How well I ean remember Green lanes wherein it grew.

The Daisies, see how gayly

Like litle stars they shine, The darlings of thy ehildhood, As once they were of mine.

The Blue-bell-when I see it, My thouglits fly back once more, To a pine-wood, whose recesses With its bloom were purpled o'er.

Go forth, dear ehild, and pluck thein, And bring thy spoils to me; Thni lov'st the gay, bright colors, 'Though thou seest not what I see!

To me they bring remembrance Of many long past Springs; Thcy are types to me and shadows Of yet more lovely things.

They have sprung in joyous beauty

From the drear and wintry earth, When all was dead and dreary, They have brought their new-born mirth. 
Their stems are weak and fragile, To the faintest wind they bend, Yet their coming is a token That deatl is not our end.

Not more of love than wisdom Was theirs, who round the tomb First brought, in faith fal-secing, Gay flowers to bud and bloom.

On every leaf is written

A sweet consoling thought; The hope of life upspringing From death, by them is brought.

My child, my happy darling, Go pluels me many a one, Thougl thou'rt the gayest flower That smiles beneath the sun!

Go forth, thou blessed being, And hring thy sweet spoils here, Though I need no other token Of heaven, when thou art near I

I need no other token Than thy fair and happy face, Through which on me are beaming God's merey and God's grace. 


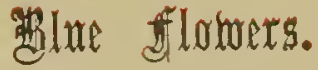

Caroline Eustis

YOU ask what flowers I love the best, When Spring ealls forth her pretty train And, eaeh in eheerful garments dressed, She sends them forth o'er hill and plain.

Give me blue flowers

To graee iny bowers,

The perfeet eolor-heaven's uwn hlue;

Sweet violet,

In emerald set, And glistening with the fragrant dew;

Or by the brook,

With downcast look,

The modest harebell's fairy form

I love to see,

Where, lovely, she

Doth bend her head to meet the storm. 
Blue flowers! - Oh give me fair blue flowers I

So pleadingly their azure eyes

Uplook in mine in morning's hours,

Taking their color from the skies:

Of hearen they learn;

To heaven they turn

Thrir opening eyes at break of day;

And heaven doth shed

On each fair head,

A blessing on them where they lay;

A blessing meet

For flowers so sweet,

A portion of her glory bright.

Let our prayer be,

Oh thus may we

Be clothed upon with robes of light] 


\section{đhe catadr.}

Andrew Sharvell.

HOW rainly men themselres amaze,
To win the palm, the oak, or bays;

And their ineessant labors see

Crown'd from some single herb, or tree,

Whose short and narrow verged shade

Does prudently their toils upbraid;

While all the flowers and trees do close,

To weave the garlands of Repose.

Fair Quiet, have I found thee here,

And Innocence, thy sister dear!

Mistaken long, I sought you then

In busy companies of men.

Your sacred plants, if here below,

Only among the plants will grow.

Society is all but rude

To this delicious solitude. 
No white nor red was erer seen

So am'rous as this lovely green.

Fond lovers, cruel as their flame,

Cut in these trees their mistress' namo.

Little, alas, they know or heed

How far these beauties her execed!

Fair trees, where'cr your barks I wound,

No name shall but your own be found.

When we have run our passion's heat,

Love hither makes his best retreat.

The gods, who mortal beauty chase,

Still in a tree did end their race.

Apollo hunted Daphne so,

Only that she might laurel grow.

And Pan did after Syrinx speed,

Not as a nymph, but for a recd.

What wondrous life is this I lead!

Ripe apples drop about my head;

The luscious clusters of the vine

Upon my moutl do erush their wine.

The nectarine, the eurious peaeh,

Into my hands themselves do reach.

Stumbling on melons, as I pass,

Ensnar'd with flowers, I fall on grase.

Meanwhile the mind, from pleasure loss,

Withdraws into its happiness ; 
The mind, that ocean where each kind Does straight its own resemblance find:

Yet it creates, transeending these, Far other worlds, and other seas ; Annihilating all that's made To a green thought in a green shade.

Here, at the fountain's sliding foot,

Or at some fruit-tree's mossy root, Casting the body's vest aside, My soul into the boughs does glide: Here, like a bird, it sits and sings: Then whets, and elaps its silver wings; And, till prepared for longer flight, Waves in its plumes the various light.

Such was that happy garden-state, While man there walk'd without a mate:

After a place so pure and sweet, What other help could yet be meet ! But 'twas beyond a mortal's share 'To wander solitary there:

Two Paradises are in one, To live in Paradise alone

How well the skilful gard'ner drew Of flowers and herbs, this dial new : Whore, from above, the milder sun Does through a fragraut zodiac run: 
And, as it works, th' industrious bec

Computes his time as well as we.

How eould sueh sweet and wholesome hours

Be reekon'd but with herbs and flowers?

\section{Slowots.}

Barry Cornoall.

WE have left behind us,

The riches of the meadows, - and now eome

To visit the virgin primrose where she dwells,

'Midst harebells and the wild-wood hyaeinths.

'Tis here she keeps her eourt. Dost see yon bank

The sun is kissing? Near,-go near ! for there,

('Neath those broad leaves, amidst yon straggling grasses)

Immaeulate odors from the violet

Spring up for ever! Like sweet thoughts that eome

Winged from the maiden faney, and fly off

In musie to the skies, and there are lost,

These ever-steaming odors seek the sun,

And fade in the light he scatters 


\section{The Hetral Slyofoet.}

Mrs. Hemans.

NOW the lucid tears of May

Gem the blossoms of the spray;

Every leaf and bending flower

Glitters in the vernal shower.

Lovely in the clouded sky

See, the Rainbow shines on high;

Mark the heavenly colors bright

Ere they vanish from the sight.

Fairer now the view around;

Brighter verdure decks the ground;

Flora, smiling in her bower,

Hails the tender vernal shower.

Cool and fragrant is the gale, Breathing sweets frow yonder vale;

Where the flowers in freshened pride

Snile upon the fuuntain sicic. 
See! again the skies appear

Clad in blue, serenely clear:

Mild and genial is the hour;

Sweet the balmy vernal shower.

\section{dyre Sun.}

Southcy.

II $\Lambda$ RVEL not, O Sun! that unto thee

In adoration men should bend the knee,

And pour forth prayers of mingled awe and love;

For like a god thou art, and on thy way

Of glory sheddest with benignant ray,

Beauty and life and joyanee from above.

No longer let these mists thy radianee shroud,

These cold, raw mists that ehill the comfortless day, But shed thy splendor thro' the opening cloud.

And eheer the world onee more. The languid flowers

Lie seentless, beaten down with heavy rain;

Earth asks thy presence, saturate with showers;

O Lord of light! put forth thy beams again,

Fur dainp and cheerless are the gloomy bowers. 


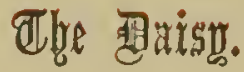

Wordsworth.

IN youth, from rock to roek I went, From hill to hill, in discontent

of pleasure ligh and turbulent, Most pleased when most uneasy;

But now my own deliglits I make,My thirst at every rill ean slake, And Nature's love of thee partake, Her much-loved Daisy!

Thee Winter in the garland wears That thinly decks his few gray hairs; Spring parts the clouds with softest airs, That she may sun thee; Whole Summer-fields are thine by right; And Autumn, melaneholy wight! Doth in thy erimson head delight When rains are on theo. 
In shoals and bands, a norrice train,

Thou greet'st the traveller in the lane,

Pleased at his greeting thee again;

Yet notling daunted,

Nor grieved if thou be set at naught:

And oft alone in nooks remote

We meet thee, like a pleasant thought,

When such are wanted.

Be violets in their secret mews

The flowers the wanton zephyr's choose;

Proud be the rose, with rains and dew

Her head impearling;

Thou liv'st with less ambitious ain,

Yet hast not gone without thy fame;

Thou art, indecd, by many a claim,

The Poet's darling.

If to a rock from rains he fly,

Or, some bright day of April sky,

Imprisoned by hot sunshine, lie

Near the green holly,

And wearily at length should fare;

He needs but look about, and there

Thou alt!-a friend at hand, to scare

His melancholy. 
A hundred times, by rock or bower, Ere thus I have lain eouehed an hour, Have I derived from thy sweet power

Some apprehension;

Some steady love; some brief delight;

Some memory that has taken flight;

Some ehime of fancy, wrong or right;

Or stray invention.

If stately passions in me burn, And one ehance look to thee should turn: I drink out of an humbler urn

A lowlier pleasure;

The homely sympathy that heeds The eommon life our nature breeds;

A wisdom fitted to the needs

Of hearts at leisure.

Fresh-smitten by the morning ray,

When thou art up, alert and gay,

Then, cheerful Flower! my spirits play

With kindred gladness :

And when, at dusk, by dews opprest

Thou sink'st, the image of thy rest

Hath often eased my pensive breast

Of eareful sadness. 
And all day long I number yet,

All seasous through, another debt,

Whieh I, wherever thou art met,

To thee am owing;

An instinet eall it, a blind sense;

A happy, genial influenee,

Coming one knows not how, nor whence,

Nor whither going.

Child of the year! that round dost run Thy pleasant eourse,-when day's begun As ready to salute the sun

As lark or leveret,

Thy long-lost praise thou shalt regain;

Nor be less dear to future men

Than in old time; - thou not in vain

Art Nature's favorite. 


\section{解rossnit.}

\section{Wordswoorth.}

" THERE," said a stripling, pointing with mueh pride,

Towards a low roof, witl green trees half-coneealed

"Is Mossgiel farm; and that's the very field

Where Burns plough'd up the daisy!" Far and wide

A plain below stretch'd seaward; while, deseried

Above sea elouds, the peaks of Arran rose;

And, by that simple notice, the repose

Of earth, sky, sea and air was vivified.

Berieath the random field of clod or stone

Myriads of daisies here shone forth in flower

Near the lark's nest, and in their natural hour

Have passed away; less happy than the one

That, by the unwilling ploughshare, died to prove

The tender charm of poetry and love. 


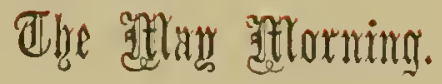

Grace Greenwoood.

THE morning brightness slowereth down from hearen $;$

1. The morning freshness goeth up from earth;

The morning gladness shineth everywhere!

Soon as the sun, in glorious panoply,

Parting the erimson eurtains of his tent,

Begins the day's proud march, the voice of song

And flush of beauty live along his way !

The maiden flowers, whom all the dreamy night,

The starlight vainly wooed, with wan, eold smile,

Blush as his presence breathes upon their bloom,

And feel his kiss through all their glowing veins, And shake the night dew from their joyous heads, And pour thick perfumes on the golden air.

The trees bow at his coming and look brave In all the richness of their new attire;

The Aspen's shining leaves give baek his smile,

Daneing in glee, yet whispering in awe, 
Like bashful maidens at some gorgeous fete, Graced by a monareli's presenee; aged Oaks Grow young again at their stout, loyal hearts; The stately brotherhood of mountain Pines Give forth a solemn greeting, like a band Of stern old monks, in sombre vestments elad. Like Ganymede, the Magnolia stands, Graceful and fair; his silver ehaliee lifts, Brimmed with night's neetar, to the thirsty god. The garden Lilae, rieh in purple bloom, Seatters her royal largess far and wide; And the warm bosom of the opening Rose Pants out its odorous sighs to the "sweet south," That soft-plumed, low. voieed rover from afar, Whose wings are heavy with the perfune stolen From the eleft hearts of his forsaken loves. The Mignonette breathes tenderly and deep, The pure home-fragranee of an humble heart; And even the tiny Violet ean make Her little eircle sweet as love; the Vine Swaying in mid-air to the frolie wind, Rains seented blossoins on the elover tufts, And eheerful daisies, lighting up the grass. The Robin and the Oriole awake With the first sunshine glaneing on their wings, To thrill the young leaves quivering round their neste With glad, wild gushes of exulting song,To pour swift waves of elear, delieious sound Eresh and rejoieing, on the morning air. 


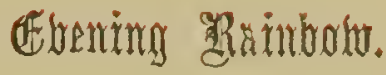

\section{Southey,}

MILD arch of promise, on the evening sky, Thou shinest fair with many a lovely ray

Each in the other melting; mueh mine eye Delights to linger on thee, for the day Changeful and many weathered, seemed to smile, Flashing brief splendor thro' the clouds the while, Which deepened dark anon and fell in rain.

But pleasant is it now to pause and view Thy various tints of frail and watery hue, And think the storm shall not return again. Such is the smile that piety bestows

On the good man's pale ehcek, when he, in peace, Departing gently from a world of woes Anticipates the world where sorrows cease. 


\section{Adight.}

William Habington.

\section{W HEN I survey the bright \\ Celestial sphere,}

So rich with jewels hung, that night

Doth like an Ethiop bride appear;

My soul her wings doth spread,

And heavenward flies,

The Almighty's mysteries to read

In the large volumes of the skies.

For the vright firmament

Shoots forth no flame

So silent, but is eloquent

In speaking the Creator's uame.

No unregarded star

Contracts its light

Into so small a eharaeter

Remov'd far from our human sight: 
But if we steadfast look We shall discern

In it, as in somc holy book, How man may heavcnly knowledge learn.

It tells the conqueror

'That far stretch'd power,

Which his proud dangers traffic for,

Is but the triumph of an hour.

That from the farthest North,

Soine nation may

Yet undiscovered issue forth, And o'er his new.got conquest sway.

Bome nation yet shut in With hills of ice

May be let out to scourge his sin, Till they shall equal him in vice.

And they likewise shall

Their ruin have;

For as yourselves your cmpires fall, And every kingdom hatk a grave.

There those celestial fires, Though seeming mute, The fallacy of our desires And all the pride of life confute. 
For they have wateh'd sinee first The world had birth, And found $\sin$ in itself accurst, And nothing permanent on earth.

\section{3ำ}

Percival

TEEL a newer life in every gale;

1. The winds that fan the flowers, And with their weleome breathings fill the sail,

Tell of serener hours, -

Of hours that glide unfelt away

Beneath the sky of May.

The spirit of the gentle south wind ealls

From his blue throne of air,

And where his whispering voiee in music falls,

Beauty is budding there;

The bright ones of the valley break

Their slumbers, and awake.

The waving verdure rolls along the plain,

And the wide forest weaves,

To weleome back its playful mates again,

A canopy of leaves. 
And from its darkening shadow floats

A gush of trembling notes.

Fairer and brighter spreads the reign of May;

The tresses of the woods

With the light dallying of the west wind play;

And the full brimming floods,

As gladly to their goal they run

Hail the returning sun.

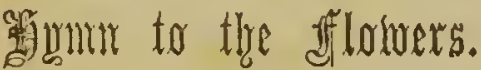

\section{Horace Smith.}

J $\mathrm{A}$ stars! that ope your eyes with morn to twinkle From rainbow galaxies of earth's creation, And dew drops on her lovely altars sprinkle As a libation!

Ye matin worshippers! who, bending lowly

Before the uprisen sun, God's lidless cye, 'I'hrow from your chalices a sweet and holy Incense on high !

Ye bright mosaics! that with storied beauty The floor of nature's temple tessellate, What nuruerous emblens of instructive dusy Your forms create ! 
'Neath eloistered boughs each floral bell that swingeth,

And tolls its perfume on the passing air,

Makes Sabbath in the fields, and ever ringeth

A eall to prayer.

Not to the domes, where crumbling areh and column

Attest the feebleness of mortal hand,

But to that fane, most eatholie and solemn,

Whieh God hath plann'd.

To that eathedral, boundless as our wonder,

Whose quenehless lamps the sun and moon supply;

Its elovir the wind and waves-its organ, thunder-

Its dome the sky.

There, as in solitude and shade I wander

'Through the green aisles, or stretched upon the sod;

Awed by the silenee, reverently ponder

The ways of God,-

Your roiceless lips, Oh flowers! are living preachers,

Eaeh eup a pulpit, and eaeh leaf a book, Supplying to my faney numerous teaehers,

From loneliest nook.

Floral apostles! that in dewy splendor,

"W cep without wo, and blush without a crime",

O, may I deeply learn, and ne'cr surrender,

Your lore sublime! 
"Thou wert not, Solomon, in all thy glory, Array'd," the lilies ery, "in robes like ours; How vain your grandeur! ah, how transitory, Are human flowers!"

In the sweet-seented pieture, heavenly Arust!

With which thou paintest nature's wide-spread hall,What a delightful lesson thou impartest Of love to all!

Not useless are ye, flowers! though made for pleasure,

Blooming o'er field and wave, by day and night, From every souree your sanction bids me treasure Harmless delight.

Ephemeral sages! what instruetors hoary

For such a world of thought could furnish scope Each fading ealyx a memento mori, Yet fount of hope.

Posthumous glories! angel-like collection! Upraised from seed or bulb interr'd in earth, $\mathrm{Ye}$ are to me a type of resurrection,

\section{A second birth!}

Were I, O God! in ehurehless lands remaining,

Far from all voice of teachers or divines, My soul would find in flowers of thy ordaining. Priests, sermons, shrines ! 


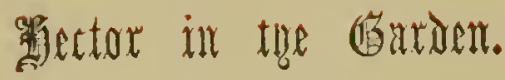

Elizabeth Barrett Broconing.

I.

NINE years old! The first of any

Seem the happiest years that come;-

Yet when $I$ was nine, I said

No such word ! - I thought, instead,

That the Greeks had used as many

In besieging Ilium.

II.

Nine green years had scarcely brought mo

To my childhood's haunted spring;-

I liad life, like flowers and bees,

In betwixt the country trees;

And the sun, the pleasure taught me,

Which he teacheth every thing.

III.

If the rain fell, there was sorrow;-

Little head leaned on the pane,

Little finger drawing down it

The long trailing drops upon it,-

And the "Rain, rain, come to-morrow"

Said for charm against the rain. 
IV.

Such a charm was right Canidian, Though you mect it with a jecr!

If I said it long enough

Then the rain liummed dinly off, And the thrush, with his pure Lydian, Was left only to the ear;

V.

And the sun and I together

Went a-rushing out of doors:

We our tender spirits drew

Over hill and dale in view,

Glimmering hither, glimmering thither,

In the footsteps of the shower.

VI.

Underneath the chestnuts dripping,

Through the grasses wet and fair,

Straight I sought my garden-ground,

With the laurel on the mound,

And the pear-tree oversweeping

A side shadow of green air.

VII.

In the garden, lay supinely

A huge giant, wrought of spade 1

Arms and legs were stretched at length

In a passive giant strength,-

And the meadow-turf, cut fincly,

Round them laid and interlaid. 
VIII.

Call him Hector: son of Priam!

Such his title and degree.

With my rake I smoothed his brow,

Both his cheeks I weeded through:

But a rhymer sueh as I am,

Searee ean sing his dignity.

IX.

Eyes of gentianella's azure,

Staring, winking at the skies;

Nose of gillyflowers and box;

Scented grasses, put for locks-

Which a little breeze, at pleasure,

Set a-waving rouud his eyce.

$\mathbf{x}$.

Brazen helm of daffodillies,

With a glitter towards the light;

Purple violets, for the mouth,

Breathing perfumes west and south;

And a sword of flashing lilies,

Holden ready for the fight.

XI.

And a breastplate, made of daisies

Closely fitting, leaf by leaf;

Periwinkles interlaced

Drawn for belt about the waist;

While the brown bees, humming praises,

Shot their arrows round the ehief. 
XII.

And who knows (I sometimes wondered),

If the disembodied soul

Of old Heetor, onee of Troy,

Might not take a dreary joy

Here to enter, if it thundered,

Rolling up the thunder-roll?

XIII.

Rolling this way; from Troy-ruin,

In this body rude and rife,

He might enter, and take rest

'Neath the daisies of the breast-

They, with tender roots, renewing

His heroie heart to life.

XIV.

Who eould know? I sometimes started

At a motion or a sound!

Did his mouth speak, naming Troy.

With an отолототог?

Did the pulse of the Strong-hearted

Make the daisies tremble round?

$\mathrm{xV}$.

It was hard to answer, often :

But the birds sang in the tree-

But the little birds sang bold,

In the pear-tree green and old;

And my terror seemed to soften,

Through the eourage of their glee. 
XVI.

Oh, the birds, the tree, the ruddy

And white blossoms, sleck with rain!

Oh, my garden, rich with pansies!

Oh, my childhood, bright romances!

All revire, like IIeetor's body,

And I see them stir again!

XVII.

And despite life's changes-chances,

And despite the death-bell's toll,

They press on me in full sceming ! -

Help, some angel! stay this dreaming !

As the birds sang in the branches,

Sing God's patience through my soul!

XVIII.

That no dreamer; no neglecter,

Of the present's work unsped,

I may wake up and be doing,

Life's heroie ends pursuing,

Though my past is dead as Hector,

And though Hector is twice dead. 


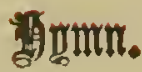

Anon

THOU Giver of all earthly good-

Thou wunder-working Power,

Whose Spirit smiles in every star,

And breathes in every flower;

How gratefully we speak Thy name,

How gladly own Thy sway,

How thrillingly Thy presenee feels

When 'mid Thy works we stray!

We may forget Thee for a time,

In seenes with tumult rife,

When worldly eares or pleasures claim

Too large a share of life;

But not in Nature's sweet domain,

Where every thing we see,

From loftiogt man? t. to lowliest flower

Is eloquent of Thee. 
Where wares lift up their tuneful voice, And solemn an thems clime,

Where winds through cchoing forests peal

Their melodies sublime;

Where'er insensate objects breathe

Devotion's grateful lays-

Man cannot ehoose but join the choir

That hymns his Maker's praise.

Beneath the city's gilded domes,

In temples decked with care,

Where Art and Splendor vie to mako

Their cartlly mansions fair ;

Our forms may lowly bend, our lips

May breathe a formal lay,

The while our wayward hearts refuse

The holy rites to pay.

But in that grander temple, reared

By thine Almighty liand,

Where glorious Beauty bids the mind's

Diviner powers expand;

Our thoughts, like grateful vassals, give

A homage glad and free,

Our souls in adoration bow, And mutely reverence Thee. 


\section{等ate Spring.}

\section{Southey.}

THOU lingerest, Spring, still wintry is the scene; The fields their dead and sapless rilsset wear;

Scaree does the glossy Celandine appear Starring the sunny bank, or, early green, The Elder yet its circling tufts put forth;

The sparrow tenants still the eave-built nest,

Where we should sec our martin's snowy breast Oft darting out. The blasts from the bleak north

And from the kecner east still frequent blow;

Sweet Spring, thou lingerest, and it should be soLate let the fields and gardens blossom out!

Like man, when most with smiles thy face is cirest, 'Tis to deceive, and he who knows you best; When most ye promise, even most will doubt. 


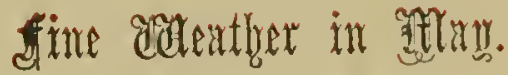

Ireigh Hunx

READER! what soul that loves a verse ean see

The Spring return, nor glow like you and me?

Hear the rich birds, and see the landscape fill,

Nor long to utter his barmonious will?

This, more than ever, leaps into the veins,

When Spring has been delayed by winds and rains,

And, coming like a burst, comes with a show

Blue all above, and basking green below,

And all the people eulling the sweet prime:

Then issues forth the hee, to eluteh the thyme,

And the bec-poct rushes into rhyme.

For lo! no sooner have the chills withdrawn, Than the bright elm is tufted on the lawn;

The merry sap has run up in the bowers,

And burst the windows of the buds in flowers;

With song the bosoms of the birds run o'er;

The euckoo ealls; the swallow's at the door; 
And apple-trees at noon, with bees alive, Burn with the golden chorus of the hive. Now all these sweets, these sounds. this vernal blazeIs but one joy expressed a thousand ways; And honey from the flowers, and song from birds, Are from the poet's pen his overflowing words.

Al, friends! methinks it were a plcasant sphere, If, like the trees, we blossomed every year; If loeks grew thick again, and vernal dyes Returned in elecks, and racincss in eyes . And all around us, rital to the tips, The human orehard laughed with eherry lips I

So natural is the wish, that bards gone by Have left it all in some immortal sigh.

But see! the weather calls me. IIcre's a bee Comes bounding in my room imperiously, And, talking to himself, hastily burns About mine ear, and so in lieat returns. O little brethren of the fervid soul, Kissers of flowers, lords of the golden bowl, I follow to your fields and tufted brooks: Winter's the time to which the poet lnoks For hiving his sweet thoughts, and making honeyed books. 


\section{đo a dofort.}

DWN, gentle flower, From the morning earth 1

We will gaze and wonder At thy wondrous birth !

Bloom, gentle flower I

Lover of the light, Sought by wind and shower, Fondled by the night !

Fade, gentle flower I

All thy white learcs close;

Having shown thy beauty,

Time 'tis for repose.

Die, gentle flower,

In the silent sun!

8o,-all pangs are over,

All thy tasks are done. 
Day hath no more glory,

Though he soars so high;

Thine is all man's story.

$$
\text { Live,-and love,-and die? }
$$

\section{The (19tigin of endimples.}

A BANOY.

ONE morning in the blossoming May, A child was sporting 'mongst the flowers Till, wearied out with his restless play, He laid him down to dream array The long and seorehing noontide hours.

At length an Angel's unseen form Parted the air with a conscious thrill, And poised itself like a presence warm Above the boy who was slumbering still. Never before had so fair a thing Stayed the swift speed of his shining wing; And gazing down with a wonder rare, On the beautiful face of the dreamer there, The Angel stooped to kiss the ehild, When lo! at the touch the baby siniledAnd just where the unseen lips had prest, A dimple lay in its swect unrest,- 
Sporting upon his eheek of rose

Like a ripple waked from its light repose,

On a streamlet's breast when the soft wind blows.

-And the Angel passed from the sleeping one,

For his mission to Earth was done.

A fair face bent abore the boy;

It must have been the boy's own mother,-

For never would such pride and joy

Hare lit the faee of any other.

And while she gazed, the quiet air

Grew tremulous with a whispered prayer;

Anon it ceased, and the boy awoke,

And a smile of love o'er his features broke.

The mother marked with a holy joy

The dimpling eheek of her darling boy,

And eaught him up, while a warm surprise

Stole like a star to her midnight eyes !-

And she whispered low, as she gently smiled,

"I know an Angel has kissed my ehild " 


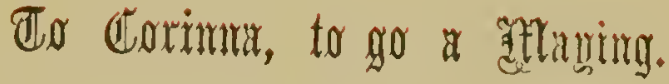

Herrick.

GET up, get up for shame! the blooning morn Upon her wings presents the god unshoru.

Sce how Aurora throws her fair

Fresh-quilted eolors through the air;

Get up, sweet slug-a-bed, and see

The dew bespangling herb and tree.

Each flower has wept, and bowed toward the east,

Above an hour since, yet you are not drest,

Nay, not so mucls as out of bed;

When all the birds have matins said,

And sung their thankful liymus, 'tis sin,

Nay, profanation, to keep in.

Whereas a thousand virgins on this day, Spring sooner than the lark to fetch in May.

Rise, and put on your foliage, and be seen To come forth, like the Spring-time, fresh and green, And sweet as Flora. Take no eare For jewels for your gown or hair; 
Fear not, the leares will strew

Gems in abundanee upon you;

Besides, the ehildhood of the day has kept, Against you eome, some orient pearls unwept.

Come, and reeeive them while the light

Hangs on the dew-loels of the night:

And Titan on the eastern hill

Retires himself, or else stands still

Till you come forth. Wash, dress, be brief in praying;

Few beads are best, when onee we go a Maying.

Come, let us go, while we are in our prime.

And take the harmless folly of the time;

We shall grow old apaee, aud die

Before we know our liberty.

Our life is short, and our days run

As fast away as does the sun;

And as a rapor, or a drop of rain

Onee lost, ean ne'er be found again;

So, when you and I are made

A fable, soug, or flecting shade;

All love, all liking, all delight

Lies drowued with us iu endless night.

Then while time serves, and we are but deeaying,

Come, my Corinna, come, let's go a Maying. 


\section{Che Cllose of Spring.}

Char otte Smith.

THE garlands fade that Spring so lately wore, Each simple flower which she had nursed in dew, Anemonies that spangled every grove-

The primrose wan, and barebell mildly blue.

No more shall violets linger in the dell,

Or purple orehis variegate the plain, Till Spring again shall call forth every bell,

And dress with humid hands her wreaths again Als, poor humanity! so frail, so fair, Are the fond visions of thine early day, Till tyrant passion and eorrosive eare Bid all thy fairy colors fade away! Another May new buds and flowers shall bring; Ah I why has happiness no second Sprirg? 


\title{
Summer.
}

\author{
R. H. Stoddand
}

THE Summer-time has come again,

1 With all its light and mirth.

And June leads on the laughing hours,

To bless the weary earth.

The sunshine lies along the street,

So $\operatorname{dim}$ and cold before,

And in the open window creeps,

And slumbers on the floor.

The country was so fresh and fino

And beautiful in May,

It must be more than beautiful,

A Paradise to-day!

If I were only there again,

I'd seek the lanes apart,

And shout aloud in mighty words,

'To ease my happy heart. 
But prisoned here witli flat brick walls,

I sit alone and sigh;

My only glimpse of Summer near,

A strip of cloudy sky.

\section{3ึme.}

Mary Nrel Meigi

AUGHINGLY thou comest, Rosy June,

With tlyy light and tripping feet, And thy garlands fresh and sweet,

And thy water's all in tune;

With thy gifts of buds and bells,

For the uplands and the dells,

With the wild-bird and the bee

On the blossom or the trece,

And my lieart leaps forth to mect thee,

With a joyous thrill to greet thee,

Rosy June;

And I love the flashing ray

Of the rivulets at play,

As they sparkle into day,

Rosy June!

Most lovely do I call theo,

Laughing June! 
For thy skies are bright and blue,

As a sapphire's brilliant hue,

And the heats of Summer noon,

Made cooler by thy breath-

O'er the clover-scented heath,

Which the scythe must sweep so soon;

And thou fann'st the ferered cheek

With thy softest gales of balm,

Till the pulse so low and reak

Beateth stronger and more calm.

And the student's listless air,

As a dreamy sound and dear,

Hath raught a pleasant murnur of the insect's busy bum

Where arching branches mect,

O'cr the turf beneath his feot.

And a thousand Summer fancies with the melody have como;

And he turneth from the page

Of the prophet or the sage,

And forgetteth all the wislom of his books,

For his heart is roving free

With the butterfly and bee,

And chimeth with the music of the brooks,

Singing still their merry tune

In the flashing light of noon,

One chord of thy sweet lyro, Laughing June!

A glimpse thou art of Heaven,

\section{Lovely June !}


Type of a purer elime

Beyond the flight of time,

Where the amaranth flowers are rife

By the placid stream of life,

For ever gently flowing;

Where the beauty of the rose

In that land of soft repose,

No blight nor fading knows

In immortal fragrance blowing.

And my prayer is still to see

In thy blessed ministry,

A transient gleam of regions that are all divinely fair ;

A foretaste of the bliss

In a holier world than this,

And a place beside the loved ones who are safely gathered there. 


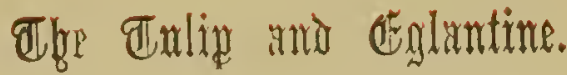

Anom

THE Tulip called to the Eglantine,

"Good neighbor, I hope you see

How the throngs that visit the garden come

To pay their respects to me.

"The florist admires my elegant robe,

And praises its rainbow ray,

Till it seems as if, through his raptured eyeo

He was gazing his soul away."

"It may be so:" said the Eglantine;

"In an humble nook I dwell,

And what is passing among the great,

I cannot know so well.

"But they speak of me as the flower of love,

And that low-whispered name,

Is dearer to ine, and my infant buds,

Thas the loudest breath of fame." 


\title{
(10n Obserbint a
}

\author{
S. T. Coleridge.
}

SWEE'T Flower! that peeping from thy russet stem Unfoldest timidly (for in strange sort

This dark, frieze-eoated, hoarse, teeth-chattering Montls

Hath borrowed Zephyr's voice, and gazed on thee

With blue, voluptuous eye), alas, poor Flower!

'These are but flatteries of the faithless year.

Perehanee, eseaped its unknown polar eave,

E'en now, the keen North East is on its way

Flower that must perish! Shall I liken thee

To some sweet girl, of too, too rapid growth,

Nipped by consumption 'mid untimely charms?

Or to Bristowa's bard, " the wondrous boy!

An amaranth, which earth searee seemed to own,

Till disappointment came, and pelting wrong

Beat it to Earth? or with indignant grief

Shall I eompare thee to poor Poland's hope,

Bright flower of hope, killed in the opening bud?

Farewell, sweet blossom! better fate be thine 
And mock my looding! dint : imilitudes Weaving in moral strains, I stole one hour From anxious self, Life's cruel taikmaster! And the warm wooings of this sunny day Tremble along my frame, and harmonize The attempered organ, that even saddest tl:oughts Mix with some sweet sensations. like harsh tumes Played deftly on a soft-tomed instrument.

\section{yalentine.}

Southey.

Co, Valentine, and tell that lovely maid Whom fancy still will image to my sight How here I linger in this sullen shade, This dreary gloom of dull, unvarying night. Say that from every joy of life remote, At evening's closing hour I quit the throng, Listening in solitude the ring-dove's note, Who pours like me her melancholy song. Say that her absence calls the sorrowing sigh; Say that of all her charms I love to speakIn fancy feel the magic of her eye,

In fancy view the smile illume her cheek; Court the lone hour when Silence rules the grove, And heave the sigh of Memory and of Love. 


\section{The 等irute's Soury.}

Aron.

A S I came o'er the distant hills,

A I heard a wee bird sing:

O pleasant are the primrose buds

In the perfumed breath of spring!

And pleasant are the mossy banks,

Beneath the birehen bowers,-

But a home wherein no ehildren play,

Is a garden shorn of flowers!"

And once again I heard the bird,

His song was loud and elear :

"How glorious are the leafy woods

In the summer of the year!

All clothed in green, the lovely boughs

Spread wide o'er land and lea,-

But the home wherein no son is born,

Is a land without a tree !" 
The birdie ceased its happy song,

I heard its notes no more;

The water rippled silently

To the blue lake's quiet shore:

But a mother sang her eradle hymu:

"All hallowed be your rest,

And Angels wateh the shining heads

That leaned on Jesus' breast I"

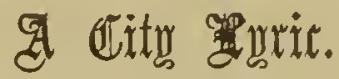

'WID the erowds I needs must linger,

Aye, and labor day by day,-

But I send my thoughts to wander,

And $m y$ fancies far away.

In the flesh I'm eloud encompassed,

Through the gloom my path doth lie;

In the spirit, by eool water,

Under sunny skies am I.

Do not pity me, my brother,-

I ean see your fountains play;

I can see your streams meander,

Flashing in the golden ray. 
And mine ear doth drink your musio, Song of birds or rippling leaves, Or the renpers' staves sung blithely . 'Mid the ripe brown barley sheaves.

I go forth at will, and gather Flowers from gardens trim and fair;

Or among the shady woodlands Cull the sweet blooms lurking there.

Little wot you, O! my brother, While I toil with sweat of brow, Of the leisure that doth wait me 'Neath the far-off forest bough.

Little wot you, looking upward At the smoke-wreaths low'ring there. That my vision is not bounded By this dull and murky air;That these thick close streets and alleys At my bidding ranish quite, And the meadows ope before me, And the greeu hills crowned with light.

Do not pity ine, my brother,God's dear love to me hath given Comfort 'ruid the strife and turmoil, And some blessings under heaveu; 
In the flesh I'n eloud eneompassed, In the gloom wy footsteps stray, But I send my thoughts to wander, And my faneics far away;

And they bring me strength for trial And sweet solace day by day.

\section{dege Teachings of etow.} FLOWERS.

Mrs. E. Oakes Smith

THE opening bud that lightly swung

Upon the dewy air,

Moved in its very sportiveness

Beneath angelic eare;

For pearly fingers gently oped

Each eurved and painted leaf, And where the eanker-worm had been Were looks of angel grief.

She loved all simple flowers that spring

In grove or sunlit dell, And of each streak and varied hue

A meaning deep would tell. She said a language was impressed On every leaf that grew, And lines revealing brighter worlds, That seraph fingers drew. 
Each tiny leaf beeame a seroll

Inscribed with holy truth,

A lesson that around the heart

Should keep the dew of youth;

Bright missals from angelic throngs

In every by-way left-

How were the earth of glory shorn

Were it of flowers bereft.

They tremble on the Alpine height-

The fissured roek tliey press-

The desert wild, with heat and sand

Shares too their blessedness;

And wheresoe'er the weary heart

Turns in its dim despair,

The meek-eyed blossom upward looks,

Inviting it to prayer.

\section{âdife.}

Charles Mackay.

A TRAVELLER through a dusty road

And one took root and sprouted up,

And grew into a tree.

Love sought its shade at evening time,

To breathe its early vows,

And Age was pleased, in heats of noon,

To bask beneath its boughs : 
The dormouse loved its dangling twigs,

The birds sweet music bore-

It stood a glory in its place,

A biessing evermore!

A little spring had lost its way

Amid the grass and fern;

A passing stranger seooped a well,

Where weary men might turn;

He walled it in, and luung with care

$A$ ladle at the brink-

He thought not of the deed he did,

But judged that toil might drink.

He passed again, and lo! the well,

By summers never dried,

Had cooled ten thousand parching tongues,

And saved a life beside!

A dreamer dropped a random thought;

'Twas old and yet 'twas new-

A simple fancy of the brain,

But strong in being true;

It shone upon a genial mind,

And lo! its light became

A lamp of life, a beacon ray,

A monitory flame.

The thought was small, its issue great;

A watchfire on the hill,

It sheds its radiance far adown,

And cheers the valley still! 
A nameless man, amid a erowd That thronged the daily mart, Let fall a word of hope and love, Unstudied from the heart;

A whisper on the tumult thrownA transitory breath-

It raised a brother from the dust, It saved a soul from deatl. O germ ! O font ! O wold of love ! $O$ thought at random east! Yc were but little at the first, But mighty at the last!

\section{Song.}

T'ennyson.

I.

A SPIRIT haunts the year's last hours,

To himself he talks;

For at eventide, listening earnestly, $\Lambda t$ his work you may hear him sob and sigh,

In the walks;

Earthward he boweth the heavy stalks of the mouklering flowers :

Heavily hangs the broad sunflower O'er its grave i' the earth so ehilly:

Heavily hangs the hollyhock, Heavily hangs the tiger-lily. 
II.

The air is damp, and hushed, and close; As a sick min's room, where he taketh repose

An hour before death:

My very heart faints, and my whole soul grieves

At the moist, rich smell of the rotting leaves,

Anci the breath

of the fading edges of box beneatl, and the year's last rose.

Heavily hangs the broad sunflower

O'er its grave i' the earth so chilly:

Heavily hangs the hollyliock,

Heavily langs the tiger-lily.

\section{Sorry for Adrgust.}

Harriet Mrrertineau.

RENEATH this starry areh

B Nought resteth or is still;

But all things hold their mareh

As if by one great will.

Mores one, move all;

Hark to the foot-fall!

On, on, for ever.

Yon sheaves were once but seed;

Will ripens into deed;

As eave-drops swell the streams,

Day thoughts yicld nightly dreams, 
And sorrow tracketh wroug,

As echo follows song, On, on, for ever.

By night, like stars on high,

The hours reveal their train;

They whisper and go by;

I never watch in vain.

Moves one, move all;

Hark to the foot-fall!

On, on, for ever.

They pass the cradle head, And there a promise shed;

They pass the moist new grave,

And bid rank rerdure wave;

They bear through every clime,

The harvests of all time,

On, on, for ever.

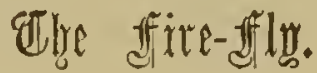

\section{Barry Cornwall.}

TELL us, o Guide!! by what strange natural laws This winged flower throws out, night after night, Such lunar brightness. Why? for what grave cause Is this earth-insect crownerl with heavenly light ? 
Peaec! Rest content! see whcre, by cliff and dell, Past tangled forest paths and silent river, The little lustrous creature guides us well, And where we fail, his small light aids us ever.

Night's shining servant! Pretty star of carth ! I ask not why thy lamp doth ever burn; Pcrhaps it is thy very life, - thy mind; And thou, if robbed of that strunge right of birth, Might be no more than Man-when Death doth turn His beauty into darkness, cold and blind.

\section{Alutumin diflowers.}

Caroline Southey.

THOSE few palc Autumn Flowers!

1 How beautiful they are!

Than all that went before, Than all the Summer store, How lovelier far!

And why?-They are the last-

The last!--the last!-the last!

Oh! by that little word, How many thoughts are stirr'd!

That sistcr of the past! 
Pale Flowers!-pale, perishing Flowers!

Ye're types of precious things,

Types of those bitter moments

That flit, like life's enjoyments,

On rapid, rapid wings.

Last hours with parting dear ones

(That time the fastest spends),

Last tears in silence shed,

Last words, half utterèd,

Last looks of dying friends !

Songs and etrouts of the fillowers.

Leigh Ilit..,

ROSES.

E are blushing Roses,
Bending witl our fulness,

'Midst our close-capped sister' buds

Warming the green coolness.

Whatsoe'cr of beauty

Yearns and yet reposes, -

Blush, and bosom, and sweet breath

Took a shape in roses.

Hold one of us lightly;

Sce from what a slender

Stalk we bow'd in heavy blooms,

And roundness rieh and tender. 
Know you not our only Rival flower, - the human?

Loveliest weight on lightest foot, Joy-abundant woman?

\section{LILIES.}

We are Lilies fair,

The flower of virgin light;

Nature held us forth and said,

"Lo ! my thoughts of white."

Ever since then, angels

Hold us in their hands;

You may see them where they take

In pietures their sweet stands.

Like the garden's angels

Also do we seem,

And not the less for being crown'd

With a golden dream.

Could you see around us

The enamored air,

You would see it pale with bliss

To hold a thing so fair. 


\section{VIOLETS.}

We are Violets blue,

For our sweetness found

Careless in the mossy shades, Looking on the ground.

Love's dropp'd eyelids and a kiss,Such our breath and blueness is.

Io, the mild shape

Hidden by Jove's fears,

Found us first i' the sward, when she

For hunger stoop'd in tears.

"Wheresoe'cr her lip sle sets,"

Jove said, "be breaths call'd Violets."

\section{SWLET-BRIER.}

Wild-rose, Sweet-brier, Eglantine,

All these pretty names are mine,

And scent in every leaf is mine,

And a leaf for all is mine,

And the scent-oh, that's divine!

Happy sweet and pungent-fine,

Pure as dew, and picked as wine.

$\Lambda$ s the Rose in gardens dress'd,

Is the lady self-possess'd;

I'm the lass in simple vest,

The country lass whose blood's the best; 
Were the beams that thread the brier

In the morn with golden tire

Scented too-they'd smell like me, All Elysian pungency.

\section{POPPIES.}

We are slumberons Poppies,

Lords of Lethe downs,

Some awake, and some asleep,

Sleeping in our crowns.

What perchance our dreams may know,

Let our serious beauty show.

Central depth of purple,

Leaves more bright than rose,

Who shall tell what brightest thought

Out of darkest grows?

Who, through what funereal pain

Souls to love and peace attain?

Visions aye are on us,

Unto eyes of power,

Pluto's always-setting sun,

And Proserpina's bower.

There, like bees, the pale sonls eome

For our clrink with drowsy lumm. 
Taste, ye mortals, also;

Milky-hearted we;

Taste, but with a reverent care;

Active, patient be.

Too much gladness brings to gloom

Those who on the gods presume.

\section{d \$till 娄an in Antumur.}

Mr's. Whitman.

T LOVE to wander through the woodlands hoary

I In the soft light of an Autumnal day,

When Stmmer gathers up her robes of glory, And like a dream of Beauty glides away.

How in each loved, familiar path she lingers, Serenely smiling through the golden mist, Tinting the wild-grape with her dewy fingers, Till the cool emerald turns to amethyst.

Kindling the faint stars of the hazel shining, To light the grloom of Autumn's mouldy halls; With loary plumes the Clematis entwining Where o'er the rek her withered garland falls.

Warm lights are on the sleepy uplands waning,

Beneath soft elouds along the horizon rolled, Till the slant sunbeams thro' their fringes raining, Bathe all the hills in melancholy gold. 
Beside the brook and on the umbered meadow, Where yellow fern-tufts fleck the fader gromin, With folded lids beneath their palmy shariow,

The Gentian nods in dewy slumbers bouml.

The little birds upon the hill-side lonely

Flit noiselessly along from spray to spray;

Silent as a sweet wandering thouglit, that only Shows its bright wings and softly glides away.

The seentless flowers in the warm sunlight dreaming,

Forget to breathe their fulness of delight, And through the traneed woods soft airs are streaning,

Still as the dew-fall of the Summer night.

So in my heart, a sweet, unwonted fecling

Stirs like the wind in ocean's hollow shell, Through all its seeret chambers sadly stealing,

Yet finds no word its mystic charm to tell.

\section{The 整loom.}

Hood.

WOTIER of light! how fairly dost thou go Over those hoary crests, divinely led!

Art thou that Huntress of the silver bow Falled of old ? Or rather, dost thou tread 
Those cloudy summits hence to gaze below,

Like the wild chanois on her Alpine snow,

Where hunter never climbed-seemre from drant?

$\Lambda$ thousind ancient fancies I lave real

Of that fair presenee, and a thousand wrouglit, Wondrous and bright, Upon the silver light,

Tracing fresh figures with the artist thonght.

What art thou like? Sometimes I see thee ride

A far-bound galley oll its perilous way.

Whilst breezy waves toss up their silvery spray :

Sometimes beliold thee glide,

Clustered by all thy family of stars,

Like a lone widow through the welkin wide,

Whose pallid eheek the midnight sol'ow mars.

Sometimes I watch thee on from steep) to steep,

Timidly lighted by thy vestal toreh,

Till in some Latinian cave I see thee crees,

To catch the young Endymion aslee]),

Leaving thy splendor at the jagged porch.

O thou art beautiful, howe'er it be !

Huntress, or Diana, or whaterer named, -

And he the veriest Pagan who first framed

A silver idol, and ne'er worshipped thee;

It is too late, or thou should'st have my knee,-

Too late now for the old Ephesian vows,

And not divine the crescent on thy lorows; 
Yet, eall thee nothing but the mere mild moon,

Behind those elıestnut boughs,

Casting their dappled shadows at my feet;

I will be grateful for that simple boon,

In many a thoughtful verse and anthem sweet, And bless thy dainty faee whene'er we meet.

\section{The extruing Giflitlobur.}

Anon.

COME, look at this plant, with its narrow, pale leares.

And its tall, slim, delieate stem,

Thinly studded with flowers !-yes, with flowers!-

There they are!

Don't you see at each joint there's a little brown star ?

But in truth, there's no beauty in them.

So you ask why I keep it? the little mean thing?

Why I stick it up liere, just in sight,--

'Tis a fancy of mine,_-"A strange fancy!" you say ;

"No acconnting for tastes!" In this instance, you may,

For the flower . . . . But I'll tell you to-night.

Some six hours henee, when the Lady Moon

Looks down on that hastion'd wall,

When the twinkling stars danee silently

On the rippling surface of the sea,

And the heavy night-dews fall ; 
Then meet me again in this easement niche,

On the spot where we're standing now.-

Nay, question not wherefore! Perhaps, with me,

To look out on the night, and the broad, bright sea, And to hear its majestie flow !

Well, we're met here again ; and the moonlight sleeps On the sea, and the bastion'd wall,

And the flowers there below.-How the night wind brings Their delieious breath on its dewy wings :

"But there's one," say you, "sweeter than all !"

Far sweeter ! and where, think you, groweth the plant That exhaleth sueh perfume rare?

Look about, up and down--But talie eare, or you'll break, With your elbow, the poor little thing that's so weak :

"Why, 'tis that smells so sweet, I declare !"

Alh ha! is it that? Have you found out now

Why I cherish that ord littlo fright ?

All is not gold that glitters, you know;

And it is not all worth makes the greatest show

In the glare of the strongest light.

There are human flowers full many, I trow,

As unlovely as that by your side,

That a common observer passeth by

Witl a seornful lip ancl a circless eye,

In the heyday of pleasure and pride. 
But move one of these to some quict spot,

From the mid-day Sun's broad glare,

Where domestic peace broods with dove-like wing;

And try if the homely, despised thing.

May not yield sweet fragrance there.

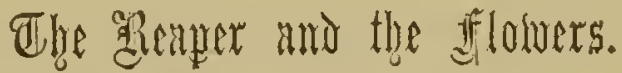

Longfelloro.

TYHERE is a Reaper whosé name is Deatl,

1 And with his sickle keen,

He reaps the bearded grain at a breath, And the flowers that grow between.

"Shall I have naught that is fair ?" saith he ;

"Have naught but the bearded grain?

Though the breath of these flower's is sweet to me,

I will give them all back again."

He gazed at the flowcrs with tearful eyes,

He kissed their drooping leares :

It was for the Lord of Paradise

He bound them in his shenves.

"My Lord has need of these flowerets gay,"

The Reaper said, and smiled ;

"Dear tokens of the earth are they

Where he was once a child. 
"They shall all bloom in fields of light,

- Transplanted by my care;

And saints, upon their garments white

These saered blossoms wear."

And the mother gave, in tears and pain,

Those flowers she most did love;

She knew she should find them all again

In the fields of light above.

Oh, not in cruelty, not in wrath, The Reaper eame that day ;

'Twas an Angel visited the green earth,

And took the flowers away. 


\section{Whe dfulls of the gatasait.}

\section{Washington Irving.}

IN a witd, tranquil vale, fringed with forests of green, Where Nature had fashioned a soft, sylvan scene, The retreat of the ringdove, the haunt of the deer, Passaic in silence rolled gentle and clear.

No grandeur of prospect astonished the sight, No abruptness sublime mingled awe with delight; Here the wild flow'ret blossomed, the elm proudly waved, And pure was the current the green bank that laved.

But the Spirit that ruled o'er the thick-tangled wood, And deep in its gloom fixed his murky abode, Who loved the wild scene that the whirlwinds deform, And gloried in thunder, and lightning, and storm;

All flushed from the tumult of battle he came, Where the red men encountered the ehildren of flame, While the noise of the war-whoop still rang in his cars, And the fresh bleeding scalp as a trophy he bears: 
Witl a glanee of disgust he the landscape surveyed, With its fragrant wild flowers, its wide waving shade:Where Passaic meanders through margins of green, So transparent its waters, its surface serene.

Ife rived the green hills, the wild woods he laid low; He tiught the purc streams in rough cliannels to flow; II c rent the rude rock, the steep precipice gave, And hurled down the ehasm the thundering wave.

Cinuntless moons have since rolled in the long lapse of timo; Cultivation has softencd those features sublimc; The axe of the white man has lightened the shade, And lispelled the deep gloom of the thieketed glade.

But the stranger still gazes, with wondering eye, On the rocks rudely torn, and groves mounted on high; Still loves on the cleff's dizzy borders to roam, Where the torrent leaps headlong, embosomed in foam. 


\section{The gedusted dflowets.}

\section{W. Bowen, M. D.}

WHEN syeamores were throwing

Their arms aeross the stream,

The cadenee of whose flowing

Like a Naiad's song might secm,

A rosy child was playing-

$\Lambda$ child of face so fair,

That she seemed a being straying

From the brighter realms of alr

On her grassy couch reclining,

By the streamlet's margin green,

A rose-bud wreath entwining

Her fair young neck was seen;

And many bright-hued flowers;

In ficld and wild-wood sought,

Culled in their gladsome hours,

That little ehild laad brought. 
And as the stream went dancing,

In all its gladness on,

Its silver ripples glaneing,

Like mirrors in the sun-

Anon, a beauteous blossom

From out her lap she drew,

Which on the water's bosom,

In her childish glee she threw.

Nor noted she the measuro

Of the loss her store sustained,

'Till of all her pretty treasure,

Nor bud, nor flower remained;

Then for those blossoms sighing,

Whieh she never more might seo,

She to the stream stood erying,

"Bring baek my flowers to me."

But onward, nothing earing

What the weeping child might say,

The waters flowed, still bearing,

All her blooming gems away;

And oft in after hours

Came baek sueh words as these,

"O bring me back my flowers,"

Borne on the fitful breeze. 
Thou gay one, who art wasting

Thine hours in idle mirth,

Who from thee time art casting,

As a thing of little worth,

She who sat thoughtless, throwing

Her treasure on the stream,

Is but thy emblem, showing

What thou to others seem.

The moments in their fleetness,

Are flowers of rich perfume-

Waste not their precious sweetness,

While yet for thee they bloom-

Lest when thou seest the hours,

Receding swift from thee,

Thou ery "Bring back my flowers,

O, bring them back to me !" 


\section{The Trtrosen Tree.}

" I'LL ehoose this tree for mine!

When I'm afar, if thou wouldst learn my fate,

Look on it-if it flourish or decline,

Such destiny, believe, will me await!

"At the return of Spring,

See, if its leaves come forth all fresh and bright;

Iist, if the robin in its branches sing

A carol gay-then know my heart is light!

"Come in the Summer days;

And visit it, and sit beneath its shade;

Seek its eool shelter from the noontide rays,

Nor let it thy forgetfulness upbraid.

"And when with Autumn's blast,

Its golden-tinted leaves abroad are hurled,

sook it its trunk be hardy to the litst,

For sueh will be my courage through the world. 
"Watch it, dear friend, for me :

'Tis bending now, to catch the water's tone!

The wave, perhaps, may whisper to the tree, Of him, who blends its thriving with his own."

And then, his name lie graved Upon the bark, and turned his steps awayAnd o'er the river, still the branches waved, And still the stream flowed on, from day to day.

And she, as years went by,

Oft randered in her walks to that lone sput;

Jut to her questionings eame no reply:

The waves were mute, the breczes answered not.

Drcamer, where art thou now?

The axe has hewn thy tree, but not destrnyed-

Rough hewn, perehance thy fortunes. Where art thou?

In what far land dost wander, how employed:

The sympathetie ehain

Of fricudship, ever eireles thee around,

And by its strong, magnetic power, again

Thy inage to thy ehosen tree is bound.

For still thy friend of old,

Is watching o'er thy visioned destiny,

Bound by her promised word, her faith to hold

In this, thy speculative prophecy. 


\section{A A}

Cuuntess of Winchelaed.

T sueh a night, when every louder wind

Is to its distant eavern safe eonfin'd, And only gentle Zephyr fans his wings, And lonely Philomel, still waking, sings ;

Or from some trec, fam'd for the owl's delight, She, hallooing elear, directs the wand'rer right.

In sueh a night, when passing elouds give plaee,

Or thinly veil the heaven's mysterious faee;

When in some river, overhung with green,

The waving moon and trembling leares are seen;

When freshen'd grass now bear's itself upright, And makes cool banks to plcasing rest invite; Whence springs the woodbird, and the bramble rose, And where the slcepy eowslip shelter'd grows; Whilst now a paler lue the foxglove takes, Yet eheekers still with red the dusky brakes;

When seatter'd glow-worms, but in twilight fine Show trivial beauties, wateh their hour to shine;

Whilst Sal'sb'ry stands the test of cvery light,

In perfect eharms and perfect virtue bright;

When odors, whieh deeliu'd repclling day,

Through tems'rate air uninterrupted stray; 
When darken'd grores their softest shadows wear, And falling waters we distinetly liear; When through the gloom more venerable shows Some aneient fabrie, awful in repose; Whilst sumburnt hills their swarthy looks coneeal, And swelling hayeocks thieken up the vale; When the loos'd horse, now as his pasture leads, Comes slowly grazing through th' adjoining meads, Whose stealing pace and lengthcu'd shade we fear, Till torn up forage in his teeth we hear, When nibbling sheep at large pursue their food, And ummolested line re-ehew their eud; When eurlews ery beneath the village-walls, And to her struggling brood the partridge ealls; Their short-liv'd jubilee the ereatures keep, Which but endures whilst tyrant man does sleep; When a sedate eontent the spirit feels, And no fioree light disturbs, whilst it reveals ; But silent musings urge tlıe mind to seek Something, too high for syllables to speal; ; Till the free soul to a eompos'dness eharm'd.

Finding the elements of rage disarm'd, O'er all below a solemn quiet grown, Joys in th' inferior world, and thinks it like her own In sueh a night let me abroad remain, Till morning breaks, and all's eonfus'd again; Our eares, our toils, our elimors are renew'd, Or pleasures, seldom reuch'd, again pursu'd. 


\section{The atse of fllowers.}

\section{Mrery IInoith}

GOD might have made the earth bring forth A Enough for great and smoll,

The oak-tree and the eedar-tree.

Without a flower at all.

We might have had enough, enough

For every want of ours,

For luxury, medieine and toil,

And yet have had no flowers.

The one within the mountain mine

Requireth none to grow;

Nor doth it need the lotus-flower

To make the river flow.

The clouds might give abundant rain;

The nightly dews might fall,

And the herb that keepeth life in man

Might yet have drunk them all. 
Then wherefore, wherefore were they made, All dyed with rainbow light,

All fashioned with supremest graee,

Upspringing day and night:Springing in valleys green and low, And on the mountains high, And in the silent wilderness Where no man passes by?

Our outward life requires them notThen wherefore had they birth? To minister delight to man,

To beautify the earth; To eomfort man, to whisper hopo, Whene'er his faith is dim, For who so eareth for the flowers Will much more eare for him. 


\section{The \$etting Surr.}

Sir Walter Scoth

THOSE evening clouds, that setting ray,

And beauteous tints serve to display

'Their great Creator's praise;

Then let the short-lived thing ealled man,

Whese life's comprised within a span,

To Him his homage raise.

We often praise the evening clouds,

And tints so gay and bold,

But seldom think upon our God;

Who tinged these clouds with gold. 


\section{The ethm Sulply.}

H. W. Parker.

A BEAUTIFUL Elm, with a maidenly form,

A That smiles in the sunlight and swings in the storm,

Has shaded my window for many a year,

And grown, like a sister, more lovely and dear.

It whispers me dreams in the soft Summer days,

It sprinkles my table with gold-floating rays;

It sings me its musie through all the hushed night, And shows me a glimpse of the stars' stealthy light;

It curtains the glare of the wakening dawn, And woos baek the dusk on the shadowy lawn.

Ob, long have I loved thee, my Elm, gentle Elm I Thou standest as proud is the queen of a realm, And winningly wavest thy soft leafy arms, Like a beautiful maid who is eonseious of eharms. Oh, oft have I leaned on thy rough-rinded breast, And thought of it of as an iron-like vestNo breast-plate of stcel, but a corslet of bark That hid the white limbs of my Joan of Are ! 
Shout, shout to thy brothers, the forests, I said, And lead out the trees with a soldierly tread; Thou art armed to the head, and hast many a plume,So marshal the trees and avert their sad rloom; Enroll all their squadrons and lead out the van, And turn the swift axe on your murderer-man! But ah, thus I said evermore,-ah, the trees, Though they wail in the tempest and sing in the breezo Have never a soul, and are rooted in earth ! They live and they die where they spring into birth; The storice of Dryads arc only a dream, And trees are no more than they outwardly seem.

\section{The Anremonte.}

Hartley Coleridge,

WHO would have thought a thing so slight, So frail a birth of warnth and light.

A thing as wcak as fear or shane, Bcaring thy weakness in thy namcWho rould have thought of sceing thec, Thou delicate Ancmone!

What power las given thee to outlast

The pelting rain, the driving blast- 
To sit upon thy slender stem,

A solitary diadem,

Adorning latest Autumn with

A relic swect of vernal pith?

O Hcaven! if, as faithful I believe,

Thou wilt the praycr of faithful love receive,

Let it be so with me! I was a child-

Of large belicf, though froward, wild.

Gladly I listened to the holy word,

And deemed my little prayers to God were heard.

All things I loved, howerer strange or odd,

As deeming all things were beloved by God.

In youth and manhood's careful sultry hours,

The garden of my youth bore many flowers

That now are faded; but my early faith,

Though thinner far than vapor, spectre, wraith,

Lighter than aught the rude wind blows away,

Has yet outlived the rude tempestuous day.

And may remain, a witness of the Spring,

A swect, a holy, and a lovely thing;

The promise of another Spring to me,

BIy lovely, lone, and iost Anemono! 


\section{(A) Atobet.}

\section{Bryant.}

$A^{Y}$, thou art welcome, heaven's delieious breath !

When woods begin to wear the crimson. leaf, And suns grow weak; and the weak suns grow hrief,

And the year smiles as it draws near its death,

Wind of the sunny south! Oh, still delay

In the gay woods and in the golden air,

Like to a good old age, released from care,

Journeying in long serenity, away.

In such a bright, late quiet, would that I

Might wear out life like thee, 'mid bowers and brooks

And, dearer yet, the sunshine of kind looks,

And music of kind voiees, ever nigh;

And when my last sand twinkled in the glass, Pass silently from men, as thou dost pass. 


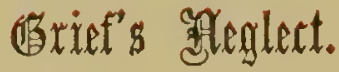

Tore zyom

TNWATCHED the garden bough shall sway.

The tender blossom flutter down.

Unloved that beech will gather brown,

This maple burn itself away.

Unloved, the sunflower, shining fair,

Ray round with flames her disk of seed,

And many a rose carnation feed

With Summer spiee the humming air.

Unloved, by many a sandy bar

The brook sliall babble down the plain,

At noon, or when the lesser wain

Is twisting round the polar star.

Uncared for, gird the windy grove,

And flood the haunts of hern and crake;

Or into silver arrows break

The sailing moon in creek and cove. 
Till from the garden and the wild

A fresh association blow,

And year by year the landscape grow

Familiar to the stranger's child.

As year by year the laborer tills

His wonted glebe, or lops the glades;

And year by year our momory fades

From all the circle of the hills.

\section{The Sensitibe 进lant.}

Percy B. Shelley.

A SENSITIV le Plant in a garden grew,

And the young winds fed it with silver dew,

And it opened its fan-like leaves to the light,

And closed them beneath the kisses of night.

And the Spring arose on the garden fail,

Like the Spirit of Love felt every where;

And each flower and herb on earth's dark breast

lose from the dreams of its wintry rest.

But none ever trembled and panted with bliss,

In the garden, the field, or the wilderness,

Like a doe in the noontide with love's sweet mant.

As the companionless Sensitive l'lant. 
The snow-drop, and then the violet, Arose from the ground with warm rain wet, And their breath was mixed with fresh odour, sent From the turf, like the voice and the instrument.

Then the pied wind-flowers and the tulip tall, And nareissi, the fairest among them all, Who gaze on their cyes in the stream's recess, Till they die of their own dear loveliness;

And the Naiad-like lily of the vale Whom youth makes so fair, and passion so pale, That the light of its tremulous bells is seen Through their pavilions of tender green;

And the hyacinth purple, and white, and blue, Which flung from its bells a sweet peal anew Of music so delicate, soft and intense, It was felt like an odour within the sense;

And the rose, like a nymph to the bath addrest, Which unveiled the depth of her glowing breast, Till fold after fold, to the fainting air The soul of her beauty and love lay bare;

And the wand-like lily, which lifted up, As a Mœnad, its moonlight colored cup, Till the fiery star which is its eye, Gazed through clear dew on the tender sky; 
And the jessamine faint, and the sweet tuberose, The sweetest flower for scent that blows; And all rare blossoms from every clime, Grew in that garden in perfect prime.

\section{(10) ont Patldanctroly.}

Keats.

NO, 110! go not to Lethe, neither twist

Wolf's-bane, tight-rooted, for its poisonous wino;

Nor suffer thy pale forehead to be kiss'd

By night shade, ruby grape of Proserpine;

Make not your rosary of yew-berries,

Nor let the beetle, nor the death-moth be

Your mournful Psyehe, nor the downy owl

A partner in your sorrows' mysteries;

For shade to shade will eome too drowsily,

And drown the wakeful anguish of the soul.

But when the melancholy fit shall fall

Sudden from heaven like a weeping eloud,

That fosters the droop-headed flowers all,

And hides the green hill in an April shroud: 
Then glut thy sorrow on a morning rose,

Or on the rainbow of the salt-sand wave,

Or on the wealth of globed peonies;

Or if thy mistress some rich anger shows,

Imprison her soft liand and let her rave, And feed deep, deep upuir her peerless eyos.

She dwells with Bealuty-Beauty that must dio:

And Joy, whose haud is ever at his lips

Bidding adieu : and aching Pleasure nigh,

Turning to poison while the bee-mouth sips:

Ay, in the very temple of Delight

Veiled Melaneholy has her sovian shrine,

Though seen of none save him whose strenuous tongue

Can burst Joy's grape against his palate fine;

His soul shall taste the sadness of her might,

And be among her eloudy trophies hung. 


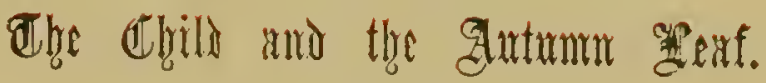

\section{Samuel Lover}

D OWN by the river's bank I stray'd Upon an Autumn day;

Beside the fading forest there, I saw a child at play.

She play'd among the yellow learesThe leaves that once were green, And flung upon the passing stream What onee had blooming been:

Oh! deeply did it touch my heart To see that child at play;

It was the sweet, unconscious sport Of childhood with decay.

Fair child, if by this stream thou stray When after-years go by,

The scene that makes thy childhood's sport May wake thy age's sigh; 
When fast you see around you fall

The Summer's leafy pride,

And mark the river hurrying on

Its ne'er returning tide;

Then may you feel in pensive mood

That life's a Summer dream;

And man, at last, forgotten falls-

A leaf upon the stream.

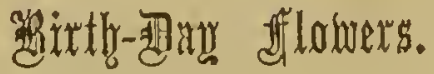

GO whisper to the gentle ono

All that our hearts would say.

Yo emblems of the fondest hopes

That erown her life to-day!

Tell her, pale Lily, as thy leaves

Benign protection yield,

So would our love around her cast

A broad and silent shield.

Breathe prophecies of happy years, Thou sweet and blushing RoseYears fragrant with as pure delight As from the chalice flows. 
And thou, meek Violet, appeal

Unto her guileless heart,

And with thy quiet loveliness

Celestial dreams impart.

Interpret thus her destiny, Whose gifts of kindred birth Lend sweetness to our daily life, And beauty to the earth.

A blooming garland softly rests Upon her modest brow, And may the Dew-Drops ne'er exhale That sparkle on it now!

Sorry tor thre Sextorr.

Eliza Cook

OOK out, look out, there are shadows about;

The forest is donning its doublet of brown, The willow-tree sways with a gloomier flout,

Like a beautiful faee with a gathering frown! 'Tis true we all know that Summer must go,

That the swallow will never stay long on our eaves! Yet we'd rather be watching the wild rose blow, Than be eounting the colors of Autumn leaves! 
Look high, look high, there's the lace-winged fly, Thinking he's king of a fairy realm, As he swings witl delight on the gossamer tie, That is linked 'mid the boughs of the sun-tipped elm ! Alas! poor thing; the first rustle will bring The pillars to dust, where your pleasure clue weaves. And many a spirit, like thine, will cling To hopes that depend upon Autuinn leaves !

Look low, look low, the night-gusts blow, And the restless forms in hectic red, Come whirling and sporting wherever we go, Lighter in dancing, as nearer the dead! Oh! who has not seen rare hearts, that have been Painted and painting, in garb that deceives, Dashing gayly along in their fluttering sheen With Despair at the core, like the Autumn leaves !

Look on, look on, morn breaketh upon The hedge-row boughs, in their withering hue; The distant orchard is sallow and wan, But the apple and nut gleam richly through.

Olı! well it will be if our life, like the tree,

Shall be found when old Time of green beauty bereaves With the fruit of good works for the Planter to see Shining out in Truth's harvest through Autumn leaves! 
Merrily pours, as it sings and soars,

The West wind over the land and seas,

Till it plays in the forest, and moans and roars,

Seeming no longer a mirthful breeze!

So Music is blest, till it meeteth a breast

That is probed by the strain, while Memory grieves

To think it was sung by a loved one at rest,

Then it comes like the sweet wind in Autumn leaves!

Nor in an hour are leaf and flower

Strieken in freshness and swept to decay;

By gentle approaches, the frost and the shower,

Make ready the sap veins for falling away!

And so is Man made to as peaeefully fade,

By the tear's that he sheds, and the sigh that he heaver,

For he's loosened from earth by each trial-cloud's shade,

Till he's willing to go, as the Autumn leaves !

Look back, look back, and you'll find the track

Of human hearts strowu thickly o'er

With Joy's dead leaves, all dry and black,

And every year still flinging more.

But the soil is fed, where the branches are shed

For the furrow to bring forth fuller sieaves,

And so is our trust in the future spread

In the gloom of Mortality's Autumn leaves | 


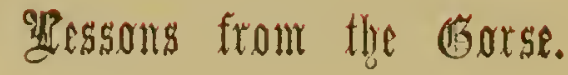

\author{
Mrs. Brononing.
}

"To win the seeret of a weed's plain heart."

LOW RLL.

NOUNTAIN Golses, ever golden!

Cankered not the whole year long!

Do you teach us to be strong,

Howsoever pricked and holden

Like your thorny blooms, and so

Trodden on by rain and snow

Up the hill-side of this life, as bleak as where ye grow?

Mountain blossoms, shining blossoms!

Do ye teach us to be glad

When no Summer can be had

Blooming in our inward bosoms?

Ye, whom God preserveth still,

Set as lights upon a hill,

Tokens to the wintry earti, that Beauty liveth still? 
Mountain Gorses, do ye teach us

From that academic chair

Canopied with azure air.

That the first fruit Wisdom reaches

Hath the hue of childly cheek?

Ye, who live on mountain peak,

Yet live low along the ground, beside the grasses meek I

Mountain Gorses! since Linnæus

Knelt beside you on the sod,

For your beauty thanking God,-

For your beauty, ye should see us

Bowing in prostration new, -

Whence arisen, if one or two

Drops be on our cheeks,-oh world! they are not tears, but dev. 


\section{gedork mittrout 䈍ope.}

Coleridge.

A LI Nature seems at work. Stags leave their lair-The bees are stirring-birds are on the wingAnd Winter, slumbering in the open air, Wears on his smiling face a dream of Spring 1 And I, the while, the sole unbusy thing, Nor honey make, nor pair, nor build, nor sing. Yet well I ken the banks where amaranths blow: Have traced the fount whenee streams of neetar flow. Bloom, Oh ye amaranths! bloom for whom ye may, For me yc bloom not! glide, rich streams, away! With lips unbrightened, wreathless brow, I stroll; And would you learn the spells that drowse my soul? Work without hope draws neetar in a sieve, And hope without an objeet eannot live. 


\section{Gemblents of diflowerts.}

A DoWN winding Nith I dicl wander,

Burns.

A To mark the sweet flowers as they spring!

Adown winding Nith I did wander,

Of Phillis to muse and to sing.

The Daisy amused my fond faney,

So artless, so simple, so wild;

Thou emblem, said I, o' my Plillis,

For she is simplieity's ehild.

The Rosebud's the blush o' my eharmer,

Her sweet balmy lip when 'tis prest:

How fair and how pure is the Lily,

But fairer and purer her breast.

Yon knot of gny flowers in the arbor,

They ne'er wi' my Phillis ean vie:

Her breatl is the breath of the Woodbine,

Its dew-drop o' diamond her eye.

Her voice is the song of the morning;

That wakes through the green spreading grove,

When Phœbus peeps over the mountains,

On music, and pleasure, and love. 
But beauty how frail and how fleeting, The bloom of a fine summer"s day! While worth in the mind o' my Phillis Will flourish without a decay.

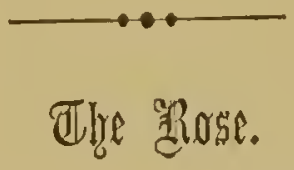

Beaumont and Fletcher.

Of all flowers,

Methinks a Rose is best . .

It is the very emblem of a maid;

For when the west wind courts lier gently,

How modestly she blows, and pannts the sun

With her chaste blushes! When the north comes near her,

Rude and impatient, then, like chastity,

She locks her beauties in her bud again,

And leaves him to base briers.

\section{The Centive and the efloluces.}

From the Germun of Goethe.

\section{CAPTIVE.}

A FLOWER that's wondrous fair, I know,
My bosom holds it dear;

To seek that flower I long to go,

But am imprisoned here.

'Tis no light grief oppresses me;

For in the days my steps were free,

I had it always near. 
Far round tlie tower I send mine eye,

The tower so steep and tall;

But nowhere ean the flower desery

From this high eastle wall;

And him who'll bring me my desire,

Or be he knight, or be he squire,

My dearest friend I'll eall.

ROSE.

My blossoms near thee I diselose,

And hear thy wretehed plight;

T'hou meanest me, no doubt, the Rose,

Thou nol,le, hapless knight.

$\Lambda$ lofty mind in thee is seen,

And in thy bosom reigns the queen

Of tlowers, as is her right.

\section{CAPTIVE.}

Thy erimson bud I duly prize

In outer robe of green;

For this thou'rt denr in maiden's eyen,

As gold and jewels' sheen.

Thy mreatl adorns the fairest brow,

And yet the flower-it is not thou,

Whom my still wishes mean.

\section{LILY.}

The little Rose las eause for pride,

And upwards aye will soar;

Yet am I held by many a bride

The Rose's wreath before. 
And beats thy bosom faithfully, And art thou true, and pure as $I_{\text {, }}$

Thou'lt prize the Lily more.

\section{CAPTIVE.}

I call myself both eliaste and pure, And pure from passions low;

And yet these walls my limbs immure

In loneliness and woe.

Though thou dost seem, in white array, Like many a pure and beautcous maid, One dearer thing I linow.

PINK.

And dearer I, the Pink, must be, And me thou sure dost choose, Or clse the gard'ner ne'er for me Such watehful eare would use; A erowd of leaves emriching blonm ! And mine through life the sweet perfume, And all the thousand hues.

\section{CAPTIVE.}

The Pink can no one justly slight, The gard'ner's farorite flower; He sets it now beneatl the light, Now shields it from its power. Yet 'tis not pomp, who o'er' the rest In splenclor slines, can make me blest; It is a still, small flower. 
VIOLET.

I stand concealed, and hending low, And do not lore to speak ;

Yet will I, as 'tis fitting now,

My wonted silence break.

For if' 'tis I, thou gallant man, Thy heart desires, thine, if I cinn, NIy perfumes all I'll make.

CAPTIVE.

The Violet I esteem incleed,

So modest and so kind ;

Its fragrance sweet yet more I need,

To soothe mine anguished mind.

To you the trutl will I confess ;

INere, 'mid this rocky dreariness,

My love I ne'er sliall find.

The truest wife by yonder brook

Will roam the mourntul day,

And lither cast the anxious look,

Long as immured I stay.

Whene'er she breaks a small blue fiower,

And says, "Forget me not!" the power

I feel, though far away.

Yes, e'en though far, I feel its night,

For true love joins us twain,

And therefore 'mid tlie dungeon's night

I still in life remain.

And sinks my lieart at my lard lot,

I lut exclain, "Forget me not!"

And straight new life regain. 


\section{etragment.}

Sir Wralter Scott.

A ND well the lonely infant knew

A Recesses where the wall-flower grew,

And honeysuckle loved to crawl

Up the low erag and ruined wall.

I deemed such nooks the sweetest shade

The sun in all his round surveyed,

And still I thought that shattered tower

The miglitiest work of human power.

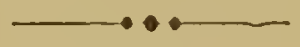

\section{Sommet.}

Spenser.

CWEET is the Rose, but growes upon a brere;

D) Sweet is the Juniper, but sharpe his bough;

Sweet is the Eglantine, but pricketl nere;

Sweet is the Firbloom, but lis lranehes rough;

Sweet is the Cypress, but his rind is tough,

Sweet is the Nut. but bitter is his pill;

Sweet is the Brome-fowere, but yet sowre enough ;

And sweet is Moly, hut lis roote is ill. 
So every sweet with sorre is tempered still, That maketh it be coveted the more:

For easic things that may be got at will, Most sorts of men doe set but little store. Why then should I account of little pain, That eadıess pleasure shall unto me gaine?

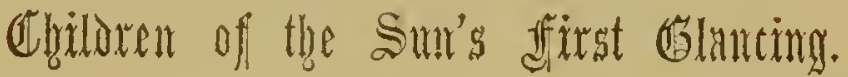

Schiller.

CHILDREN of the sun's first glancing;

$\checkmark$ Flowers that deek the bounteous earth;

Joy and mirth are round ye daneing,

Nature smiled upon your birth;

Light hath veined your petals tender, And with hues of matehless splendor

Flora paints cach dewy bell;

But lament, ye sweet spring blossoms, Soul hath never thrill'd your bosoms,

$\Lambda \mathrm{ll}$ in eheerless night ye dwell.

Nightingale and lark are singing

Many a lay of love to you;

In your chaliced blossoms swinging,

Tiny sylphs their sylphids woo;

Deep within the painted bower

Of a soft and perfumed flower,

Venus onee did fall asleep;

But no pulse of passion darted

Through your breast, by her imparted-

Children of the morning, weep. 
When my mother's harsh rejeetion

Bids me eease my love to speak-

Pledges of a true affection,

When your gentle aid I seek-

Then by every voiecless token,

Hope, and faith unehanged, are spoken,

And by you my bosom grieves;

Love himself among you stealeth, And his awful form enneealetll,

Shut within your folding leaves.

\section{dflowers for the eforent.}

\section{F. Fliiott.}

TLOWERS! winter flowers-the ehild is lead,

1 The mother' cannot speak;

Oh, softly couch his little heart, Or Mary's heart will break !

Amid those eurls of flaxen laair This pale pink riband trine, And on the littie bosom there Place this wan loek of mine.

How like a form in cold wlite stone,

The eoffin'd infunt lies!

Inok, mother, on thy little one,

Aucl tears will fill thine eyes. 
She cannot weep, more faint she grows,

More deadly paice and still;

Flowers ! oh, a tlower ! a Winter Rose,

That tiny hand to fill.

Go, seasch the ticlds ! the lichen wet

Bends o'er th' unfailing well;

Beneath the furrow lingers yet

The searlet Pimpernel.

Peeps not a Snowdrop in the bower,

Where never froze the spring?

A Daisy? ah! bring childhood's flower!

The half-blown Daisy bring !

Yes, lay the Daisy's little head

Beside the little cheek;

Oh, haste! the last of five is dead!

The childless cannot speak !

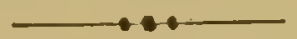

\section{flocuets:}

\section{SENT ME DURING IIILNESS.}

Richard II. I's!'.

LOVED you ever, gentle flowers,

1 And made you playmates of my youth;

The while your spirit stole

In seerct to my soul,

To shed a softness through my ripening powers, And lead the thoughtful mind to deepest truth, 
And now, when weariness and pain

Had cast you almost from my breast,

With each a smiling faee,

In all your simple grace,

You come onee more to take me brek again

From pain to ease, from weariness to rest.

Kind visitants! through my siek room

You seem to breathe an air of haalth,

And with you looks of joy

To wake amain the boy,

And to the pallid cheek restore its blonm, And o'er the desert mind pour boundless wealth.

And whenee ye came, by brimming stream, 'Neath rustling leaves, witl birds within,

Again I musing tread-

Forgot my restless bed,

And long sick hours-Too short the blessed dream !

I woke to pain !--to hear the eity's din !

But time nor pain shall ever steal

Or youth or beauty from my mind;

And blessings on ye, flowers,

Though few with me your hours, The youth and beauty and the heart to feel. In her who sent you, ye will leave behind: 


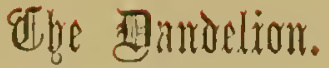

James Russel Lonoell.

D EAR eommon flower, that grow'st beside the way, Fringing the dusty road with harmless gold;

First pledge of blithesome Miay,

Whieh ehildren pluck, and full of pride, behold,

High-hearted buecuneers, o'erjoyed that they

An El Dorado in the grass have found,

Which not the rich carth's ample round

May match in wealth,--thou art more dear to me

Than all the prouder Summer blooms may be.

Gold sueh as thine ne'er drew the Spanish prow

Through the primeval hush of Indian seas,

Nor minkled the lean brow

Of age, to rol) the lover's heart of case,

'Tis the Spring's largess, which she seatters now

To rich and poor alike, with lavish hand,

Though most hearts never understand

To take it at God's vilue, lut pass by

The offered wealth with unrewarded eyo. 
Thou art my tropies and mine Italy;

To look at thee unlocks a warmer clime; The eyes thou givest me

Are in the heart, and heed not space nor time;

Not in mid--June, the golden cuirassed bee

Feels a more Summer-like, warm ravishment,

In the white hily's breezy tent,

His conquered Sybaris, than I, when first

From the dark green thy yellow circles burst.

Then think I of deep shadows on the grass,-Of meadows where in sun the cattle graze, Where, as the breezes pass,

The gleaming rushes lean a thousand ways;-

Of leaves that slumber in a cloudy mass,

Or whiten in the wind,-or waters blue

That from a distance sparkle through

Some woodland gap, - and of a sky above

Where one white cloud like a stray lamb ioth move.

My childhood's earliest thoughts are linked with thee;

The sight of thee calls baek the robin's song,

Who, from the dark oak tree

Beside the door, sang clearly all day long,

And I, seeure in childish piety,

Listened as if I heard an angel sing

With news from heaven, which he did bring

Fresh cvery day to my untainted ears,

When birds and flowers and I were happy peers. 
How like a prodigal doth Nature seem,

When thou, for all thy gold, so eommon art!

Thou teachest me to deem

More sacredly of every human heart,

Since each reffects in joy its seanty gleam

Of heaven, and could some wondrous seeret show,

Did we but pay the love we owe,

And with a cliild's undoubting wisdom look

On all these living pages of God's book.

\section{To the Snowdrop.}

Butry Cornoall.

DRETTY firstling of the year !

1 IIcrald of the host of flowers !

- Hast thou left thy cavern drear,

In the hope of Summer hours?

Back unto thy earthen bowers!

Back to thy warm world below,

Till the strength of suns and showers

Quell the now relentless snow.

Art still here?-Alive and blythe?

Though the stormy night hath fled,

And the frost hath passed his scythe,

O'er thy small unsheltered head?

$\Lambda \mathrm{h}$ ! some lie amidst the dead,

(Many a giant stubborn tree,-

Many a plant, the spirit shed,)

That were better nurser than thee ! 
What hath saved thee? Thou wast not

'Gainst the arrowy Winter furrer,-

Armed in seale,-but all forgot

When the frozen winds were stirred.

Nature, who doth elothe the bird,

Should have hid thee in the earth,

Till the euekoo's song was heard,

And the Spring let loose her mirtl.

Nature, - deep and mystie word!

Mighty mother still unknown!

Thou did'st sure the Snowdrop gird

With an armor all thine own!

Thou, who sent'st it forth alone

To the eold and sullen season,

(Like a thought at random thrown, )

Sent it thus for some grave reason ?

If 'twere but to pieree the mind

Witlı a single gentle thought, Who shall deem thee harsh or blind?

Who that thou hast vainly wrought :

Hoard the gentle virtue eanght

From the Snowdrop,-reader wise :

Good is good, wherever taught, On the ground or in the skies! 


\section{titid floforers.}

\section{Camplell.}

$\mathrm{Y}^{\mathrm{E}}$ field flowers ! the gardens eelipse you, 'tis true, Yet wildings of nature, I dote upon you,

For ye waft me to Snmmers of old, When the earth teemed around me with fairy delight, And when daisies and buttercups gladdened my sight, Like treasures of silver and gold.

I love you for lulling me back into dreams, Of the blue Fighland mountains and echoing streams, And of birchen glades breathing their balm ; While the deer was seen glaneing in snnshine remote, And the deep, mellow crush of the wood-pigeon's note, Made music that sweetened the ealm.

Not a pastoral soug has a pleasanter tune

Than ye speak to my heart, little wildings of June ;

Of old ruinous eastles ye tell,

Where I thought it delightful your beauties to find, When the magie of nature first breathed on my mind, And your blossoms were part of the spell. 
Thou hast a grarden for us, where to bide.

Who would be more,

Swelling through store,

Forfeit their Paradise by their pride.

\section{Tlye 皱故odota.}

Eimerson.

TN May, when sea-winds pierced our solitudes,

1 I found the fresh Rhodora in the woods;

Spreading its leafless blooms in a damp nook, To please the desert and the sluggish brook.

The purple petals, fallen in the pool,

Made the black watcr with their beanty gay ;

Here might the red-breast come, his plumes to cool,

And court the flower that cheapens his array.

Rhodora! if the sages ask thee why Thy charm is wasted on carth and sky, 
Tell them, dear, that if eyes were made for seeing,

Then beanty is its own exeuse for being.

Why thou wert here, O rival of the rose!

I never thought to ask-I never knew ;

But, in my simple ignoranee, suppose

The self-same power that brought me there, brought you.

\section{Thye fiflotoret.}

George Herbert.

How fresli. O Lord, how sweet and elean

Are thy returns, e'en as the flowers in Spring;

To which, besides their own demean,

The late-past frosts tributes of pleasure bring.

Grief melts away

Like snow in May;

As if there were no such cold thing.

Who would have thought my shrivell'd heart

Could have reeovered greenness? It was gone

Quite underground, as flowers depart

To see their Mother-root when they have blowu;

Where they together

All the hard weather

Dead to the worlel, keep house unknown.

These are thy wonders, Lord of power, Killing and quiekening, bringing down to hell

And up to heaven in an hour ; 
Making a chiming of a passing bell,

We say amiss

This or that is :

Thy word is all ; if we could spell.

O that I once past changing were,

Fast in thy Paradise, where no flower can wither!

Many a Spring I shoot up fair,

Offering at Heaven, growing and groaning thither :

Nor doth my flower

Want a spring-shower,

My sins and I joining together.

But while I grow in a straight line,

Still upwards bent as if Heaven were mine own,

Thy anger comes and I decline :

What frost to that? What pole is not the zone

Where all things burn,

When thou dost turn,

And the least frown of thine is shown?

And now in age I bud again;

After so many deaths I live and write;

I once more smell the dew and rain,

And relish versing; $\mathrm{O}$ my only light

It cannot be

That I am he

On whom thy tempests fell all night!

These are thy wonders, Lord of love !

To make us see we are but flowers that glide,

Which when we once can find and prove 


\section{gatril.}

\section{H. W. Longfellon.}

$A^{\text {LL day the low-hung clouds have dropped }}$ A Their garnered fulness down ;

All day that soft gray mist hath wrapped Hill, valley, grove and town.

There has not been a sound to-day

To break the caln of nature;

Nor motion, I might alnost say,

Of life, or living creature,-

Of waving hough, or warbling bird,

Or cattle faintly lowing,

I could have half believed I heard

The leaves and blossoms growing.

I stood to hear-I love it well-

The rain's continuous sound ;

Small drops, but thick and fast they fell

Down straight into the ground. 
For leafy thiekness is not yet

Earth's naked breast to screen, Though every dripping branch is set With shoots of tender green.

Sure, sinee I looked at early morn, Those honeysuekle buds

Have swelled to double growth; that thorn Hath put forth larger studs;-

That lilae's eleaving eones have burst, The milk-white flowers revealing; Even now upon my senses first Methinks their sweets are stealing.

The very earth, the steaming air, Is all with fragrance rife;

And graee and benuty everywhere Are flushing into life.

Down, down they eome-those fruitful stores! Those earth-rejoicing drops 1

A momentury deluge pours, Then thins, decreases, stops.

And ere the dimples on the stream

Have cireled out of sight,

Lo! from the west, a parting gleam

Breaks forth of amber light. 
But yet, behold! abrupt and loud, Comes down the glittering rain; The farewell of a passing cloud, The fringes of her train.

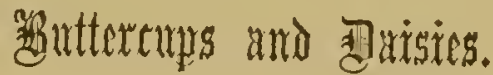

Mary Howitt.

\section{R UTTERCUPS and Daisies- \\ D Oh! the pretty flowers!}

Coming ere the Spring-time

To tell of sunny hours.

While the trees are leafiess,

While the fields are bare,

Buttereups and Daisies

Spring up here and there.

Ere the snow-drop peepeth;

Ere the croeus bold;

Ere the early primrose

Opes its paly gold ;

Somewhere on a sunny bank

Buttercups are bright!

Somewhere 'mong the frozen grass

Peeps the Daisy white.

Little hardy flowers

Like to children poor

Playing in their sturdy health

By their mother's door; 
Purple with the north-wind, Yet alert and bold,

Fearing not and caring not,

Though they be a-cold!

What to them is weather!

What are stormy showers!

Buttercups and Daisies

Are these human flowers!

He who gave them liardship

And a life of care,

Gave them likewise hardy strength,

And patient hearts to bear.

Welcome, yellow Buttercups!

Welcome, Daisies white!

Ye are in my spirit

Visioned, a delight!

Coming ere the Spring-time,

Of sunny hours to tell-

Speaking to our hearts of Him

Who doeth all things well. 


\section{settuy.}

Willis.

$\mathrm{O}^{\mathrm{H} \text {, the merry day has pleasant hours, }}$

And dreamily they glide,

As if they floated like the leaves

Upon a silver tide.

The trees are full of crimson buds,

And the woods are full of birds,

And the waters flow to music,

Like a tune with pleasant words.

The rerdure of the meadow-land

Is creeping to the hills,

The sweet, bluc-blossom'd violets

Are blowing by the rills ;

The lilae has a load of balm

For every wind that stirs,

And the larch stands gréen and beautiful

Amid the sombre firs.

There's perfume upon every wind-

Musie in every tree-

Dews for the moisture-loving flowers,

Sweets for the sucking bee; 
The sick come forth for the healing south, The young are gathering flowers;

And life is a tale of poetry

That is told by golden hours.

If 'tis not a true plilosoplyy, That the spirit, when set free, Still lingers about its olden home, In the flower and the tree, it is very strange that our pulses thriil At the sight of a voiceless thing, And our hearts yearn so with tenclernciss

In the beautiful time of Spring. 


\section{INDEX OF FIRST LINES.}

Page

A beantiful clm, with a maidenly form.........II. W. Purker........ 4!/9

A boy canglat sight of a rose in a bower......... Goethe........... 349

Aduwn winding Nith I did wander............ Burns........... 515

A faded blue-bell iu a chest of ten............II. W. Iarker....... 330

A flower that's wondrous fair I know.......... Goethe........... 510

After the slumber of the year.............. Shelley .......... 43

$\Lambda$ good old eotntry lodge, half hid with blooms. . Leigh ITunt......... 343

Ah me ! ah, woe is me !. .................hrs. Osgood........ 97

Ah ! see whose fayre thing doest faine to see .... Spenser ............. 99

A lily flower.......................... Vordsworth ........ 161

All-beanteons flower ! whose center glows........Anonymous......... 199

All day the low-hung clouds have dropped........I. W. Longfellow..... 533

All Nature seems at work. Stags leave their lair.. Coleriage........... 514

A myrtle, fairer than ................... Keats............. 118

And there upon the sod below ............... Anonymous......... 180

And well the lonely infant linew..............Sir IV. Scott........ 5æ0

Ald where have you been, my Mary ........... Hary Howitt........ 535

An early rose, borne from her genial bower...... Charlotle Smith....... 30.)

An exquisite invention this ............... Leigh IIunt........ 9

Anmouneed by all the trumpets of the sliy ....... R. W. Emerson....... 293

Arise and speak thy sorruws, Fchn, risc........ Ben .Jonson......... 49

A sensitive plant in a garden grew............ B. Shelley........ 503

$\Lambda s$ Hope, with bowed hear, silent stood ........ Anonymous......... 21

As I came $0^{\prime} \mathrm{el}^{*}$ the distant hills.............. Anonymous........ 465

A single rose is shedding there............... Lord Byron......... 99

A slender tree upon a heiglit in lonely beauty towers ............................Bluckwood's Mrag..... 190

A spirit haunts the year's last hours........... Tennyson.......... 471

At Greenwood, where, through branehes green...J. A........... 302

$\Lambda$ traveler through a dusty road............. Charles Mackay....... 468

A tuft of evening primroses............... Keats............ 63

Autumn, while into languid winter drooping......L. E. Land.on........ 92

A violet blossom'd on the green ............. Goethe.......... 43

A willow garland thou didst send ............. Moore. ........... 144 
A wrinkled, crabbed man they picture thec...... Southey.............286

Ay, thou art welcome, heaven s delicious breath.. H. C. Brylant........ 501

Beautiful child of a tropic sun............... Anonymous......... 170

Beneatlı this etarry arch..................II. Martinecu....... 472

Brave sons of Hibernia, your shamrocks display.. Anouymous.......... 149

Bright flower whose home is everywhere.... .... Vordsworth........ 16

Buds of roses, virgin flowers.................. Thas. Hoore ......... 104

Buttercups and daisies ...... ..............Mary Howill....... 535

But we have daisies, which, like love............John Wïlson........ 64

By what rule, stranger, shall we fix thy date..... Anonymons......... 325

Cheerful 'midst desolation's sadness-thou.......Anonymons......... 86

Child of the country ! free as air ............ Cunningham........ 339

Child of the spring, thou charming fower....... Casimir........... ris

Child of the sun ! pursue thy rapturous fight.... Rorgers............. 314

Children of the sun's first glancing............ Schiller............ 521

Come, all ye virgins fair in kirtles white....... R. II. Stoddard...... 398

Come ; -let us go to the land.................Barry Cornwall...... 409

Come, look at this plant, with its narrow, pale

leaves.......................... Anomymont........ 482

Come, melancholy noralizer, come..$\ldots \ldots \ldots$ Southey........... 318

Daisic of light ! very ground of comfort....... Chaucer.......... 16

Daw'n, gentle flower ...................Anonymous......... 452

Day stars ! that ope your eyes with morn to twinkle. Itorace Snith........ 439

Dear common flower, that grow'st beside the way...J. $R$. Lowell... ..... 525

Dear girl, I send the spray of flowers..............Tohn Ingram....... 92

Despise not the wild flower-small it seems...... Anonymous......... 158

Did Jove a queen of flowers decree............Elton............ 102

Dip down upon the northern shore............. Tennyson........ 332

Down by the river's bank I stray'd..............Samuet Lover......... 507

Down swept the chill wind from the mountain

peak ...............................J. R. Lowell .........

Elle était de ce monde, où les plus belles choses...Mulesherbes......... 354

Ever let the fancy roam ................. fieats............. 267

Fair daffodils, we weep to see...............terrick........... 36

Fair pledges of a fruitful tree................. Iferrick........... 34

Fair tree of winter, fresh and flowering.........Monlgomery........ 298

Fall ! thickly fall ! thou winter snow..........R. II. Sloddard...... 299

Flower of the mountain! by the wanderer's hand...Mrs. Kembie........ 297

Flower of the waste ! the heath-fowl sluns........4\% Grant ........ 173

Flowers of the wildwood! your home is there.... Miss Prall.......... 129

Flowers! winter flowers-the child is dead........ E. Elliolt ............ 522

For Daphne's laurel Phœbus gave his voice.......Garcilass' ... . ..... 145

For me,-she stooped, and, looking round........Sir W. Scolt........ 208

Four seasons fill the measure of the year......... Keals............. 280 
From thine Eden of the sen .................. PAN

Furth goth all the courte wo..............W. I. Ialmer....... 288

Furth goth all the courte, both most and lest.... Chaucer.......... 55

Gather ye rosebud: while ye may.

Gay lilies on the virgin breast.................... Thos. Ilood.

Ilerrick.

God might have made the earth brincr forth....... Counless of Winchelsea. 390

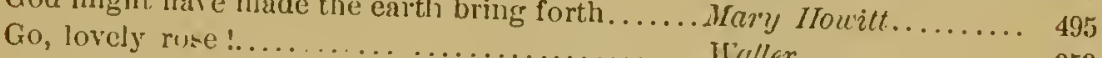

Good neighbor eow:lip, I have seen the....... Wuller............ 353

Go 10 your peaceful rest.............. Sigourney. .... 27

Go, valentine, and tell that lovely maid ........Mrs. Sigourney...... 272

Go whisper to the gentle one .............. Southey.......... 337

Green little vanl ter in the sunny grass ...........Anonymons.......... 508

Green willow l over whom the perilons ......... Anonymions......... 375

Growth of jusnine twied.... perilons blast.....L. E. Landon....... 145

A. Terinyson.......... 130

Tlast thou seen, in winter's stormiest day........Barton........... 180

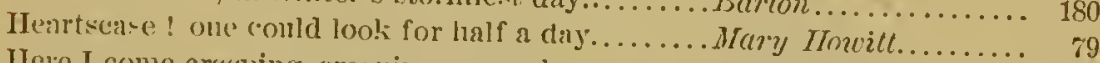

Ilere I come crecping, crecping everywhere....... Anomymous.......... 415

Ifere this rosc . ......................... Burry Corueall...... 135

IIere young Nareissus o'er the funtain stond ... Grty ............ 51

IIs garment wal every dele................ Chaucer ........... 515

IIow fresh, O Lord, how swcet and el'an........ Georye Ilerbert........ 531

How happily, how liappily the flowers dic away ... C. Bowle.......... 211

Ilow lovlily the jatinine flower............. Ry

Ilow many bright fowers now around me....... A nomymous.......... 91

Ilow now, shepherde, what means tliat.......... Percy's Reliques....... 142

IIow oft, thougl grass and moss are seen ........ Anomymous... . . . 174

Ilow vainly men thenselves amaze. ..... ..... Ardrev Marvell ..... 422

How sweet it were, hearing the downward stream. . A. Tennyson......... 176

I culled each flow'ret for my fair.............. Anonymous........ 91

I do love violets ......................... L. Landion.......... ${ }_{42}$

I dreamed that, as I wandered by the way....... Shelley........... 134

I feed a newer life in every $:$ ale ................ Perciral ............ 498

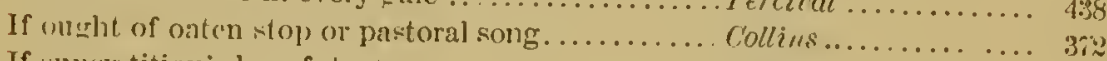

If superstition $\leqslant$ bancfut art ................ Barton ........... 200

If you wonld see the lady fern..................... Caller Campbell..... 110

I give to thee the autumn rose...............Christine Pire....... 10

I had found ont a sweet green spot ............... G. Percival... ... 3.

I know a bank whereon the wild thyme blows..... Shakesp are... 43 and 153

I know a momt, the gracious sun perecives........ Robt. Browing. ... 14.

Il descend li cercneil : et les roses suns tache...... Chateanbriand... ... 345

I'll chorise this trec for mine $\ldots \ldots \ldots \ldots \ldots \ldots .$. "Estelle"........... 491

I loved you ever, gentle flowirs ............... II Dana......... ${ }_{523}^{491}$

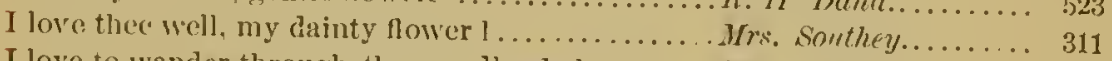

I love to wander through the woodlands hoary...... Hr... Whilman...... 479

I marvel not, $O$ sun I that unto theo........... Southey ........... 427 
In a brook that loved to fret...

J. II. Rernnolds

164

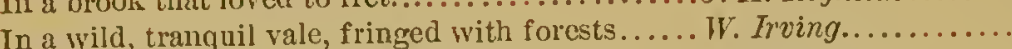

I never wander 'mong the flowers................ Anonymous ..........

In gardens oft a beauteous flower there grows .....Wrs. Sheriden .......

In May, when sea-winds piereed our solitudes.....R. W. Emerson........

Innocent child and suow-white flower..........W. C. Bryant........

In Spring's green lap there blooms a flower ....... Caroline Symonds.....

In such a night, when every louder wind........ Couniess of Winchelsea.

Into the sunshine........................ Anonymous..........

In youth, from rock to rock 1 went... ......... Fordsworth.........

I saw it in my evening walk.................IIrs. ITemans.........

I saw the pride of all the meadow............. Cowper.............

I send the lilies given to me ................. Lord Byron...........

Its tender shoots, fostered with enre, extend......Anonymons.......... 201

I used to love thee, simple flower............... Anonymous......... 82

I wandered lonely as a cloud................. Wordsworth........ 37

I will not liave the mad Clytie................Thos. IIood......... 149

Just like love is yonder rose ................ Camoens.......... 100

Keen fitful gusts are whispering here and there... Keats ............. 279

Laud the first spring daisies

Edward Youl........ 412

Laughingly thon comest ..................Mary Noel Meigs......

Let louglived pansies here their scerts bestow....Anonymous ..........

Let then boast of the eountry gave Patrick lis

fame.............................. Ettrick Shepherd.....

Light-cnchanted sunflower! Thoul............. B. Shelley.........

Lilae of Persia ! tell ns some fine tale............ Mrs. Sigourney........

Live while you live, my boys $1 . \ldots \ldots \ldots \ldots \ldots$..... Anonymous..........

Lone flower, hemmed in with snows, and white as

they ................................... . 20

Long liave you my lanrels worn............. Leigh $I$ lunt......... 151

Look out, look out, there are sliadows about...... Eliza Cook.......... 50 .

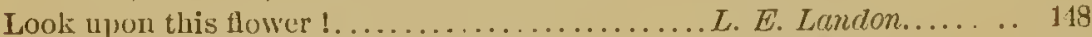

Love's language may be talled with these......E. B. Browning..... \&

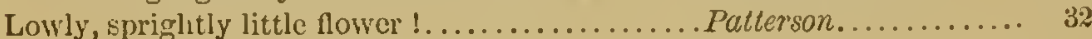

Many a perfume breathed..................... Thos. Moore......... 121

'Mlid the crowds I needs must linger............T. Westwood........ 466

Mild arch of promise, on the evening sky........ Southey ........... 435

MIild offspring of a dark and sullen sire $\ldots \ldots \ldots \ldots$. K. White....... 69

Misty moonlight, faintly falling................ R. B......... 161

Most glorions lose ......................... Sigourney.......... 95

Nlother of light, how fairly dost thou go ........ Hood ............ 480

Mountain gorses, ever golden.... ............. E. B. Browning..... 512

My gentlc Pnek, coine lither .............. Shakeqpeare........ 79

My heart's to me a pleasant greenhouse. ......W. L............ 3:27? 
My own land $!$ my own land! where freedom finds

her throne-land...

Shakespeare.

PAGS

My slight and slender jasmine-tree............ Lord Iforpeth.........

I: $\operatorname{CoO}$.

Next thereunto did grow a goodly tree......... Syenser........... 126

Nine years old ! The first of any ............E. L. Browning...... 44:

No, no ! go not to Letlic, ncither twist......... . Keat's........... 505

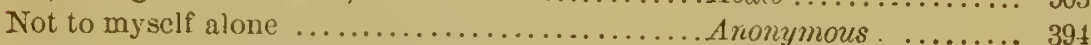

Now departs day's garish light................. Anorymous......... $2 \pi 0$

Now folds the lily all her sweetness up........... Tennyson......... 162

Now the lueid tears of May ..............IIrs. Iremans........ 426

Of all flowers.............................ecurnont \& Flelcher. 156

Of all the months that fill the year..............E. Lundon. ..... 33

O glad triumphal bough ................ Taseo............ 152

Oh, a dainty plant is the ivy green............ Dickens.......... 178

Oh! bring me one sweet orange-bougl .......... Irs. ILemans.......... 128

Oh! falsely they accuse me. ................ Calder Campbell....... 150

Oh! fragrant dwelless of the lea............. Yary Iloward....... 27

Oh 1 plant them above me, the soft and bright....L. E. Letndon......... 106

Oh rose ! who dares to name thec ?............... B. Brovining....... 281

Oh ! the heart that onee truly loves, nerer forgets..'Thus. Iloore......... 150

Ol, the merry day has pleasant hours......... Irillis............ 537

Oh waning moon, that with diminished horn ....... E. Slarr .......... 407

Oh werc my love yon lily fair.............. Burns........... . 176

Oh, we will go a-Maying, love............... John Ingram......... 56

O lady, twine no wreath for me.............. Sir If. Scolt.......... 189

O melon-secnted !ily.... .................... II. Reyrolds........ 166

Onc day, young frolic Cupid tried ............ Anomymons......... 352

One molning in the blossoming May............ Anonymous........... 453

On Christmas cve the bells were rung..........IItfman............. 198

Open afresh your round of starry folds......... fieals.............. 159

Orplian honrs, the year is dead $\ldots \ldots \ldots \ldots \ldots \ldots$. Shelley .............. 316

O render! hast thou ever stood to see ......... Southey ........... 20 :

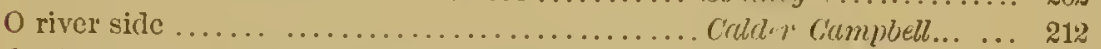

Or they might wateh the quoit pitehers, intent... Feats............ 69

O Sacred Providence, who from end to end .......George Trerbert....... 539

Onr sweet autumnal western-seented wind .......Brainard........... 115

Pale flower-pale, fragile. faded flower. .........15rs. Whitman...... 329

Pansies, lilies, kingeups, daisies..............Wor dsworth........ 138

Plcasant beneall this burning sky of June ...... Irilliam Sawyer...... 125

Pretty firstling of the year................... J3arry Cornwall....... 5. 587

Pridc of the garden, the beanties, the regal....... Anonymonts ......... 147

Primroses ........................... E. El. Lee......... 67

Reader! what sonl that loves a verse can see ..... Leigh Tuat.......... 
PAG

Real faith is like the sun's fair flower......... Anonymous ........ 150

Restless forms of living light............... Itarley Coleridge..... 352

Rose ! what dost ihou liear...................MIs. Ilemans........ 100

See how the orimt dew ................... Anonymous........ 350

See how yon glittering wave in sportive play....... Miss Pickersgill...... 87

See the honeysuckle twine................. Counless of Blessington 132

She, enamoured of the sun....................Anonymous...... 114

She stepped upon sicilian grass............... Jean Ingelow........ 35

She witl distracted passion pines away.......... Ovid............. 113

Shrubs there are....................... Thomson.......... 175

Since still my passion-plcading strains..........De La Vega......... 48

Sing on, swect thrusli, upon the leafless bough....Burns............ 317

Slecp-bringing poppy, by the plowman late...... William Browne...... 121

Some years ago a dark-eycd maid .............. O. WF. Llolmes..... if

Spake full well, in language quaint and oldcn.....II. W. Longfellow..... 404

Summer was on the hills when last we parted...... Joir............. S9

Sweet Echo, sweetest nymph, that liv'st unseen... Mfillon............ 47

Sweet flower, that pecping from thy russet stem. S. T. Coleridge....... 336

Sweet berald of the ever gentle spring.......... Carringlon.......... 64

Sweet is tlie rose, but grows upon a brere........ Spenser. .......... 5:0

Swect jessamine, long may thy elegant flower....Jahe Taylor......... 123

Sweet scented tlower! who art wont to bloom....H. K. While......... 70

Swect-william small, has form and aspect bright. . Cowley........... $16 \%$

Tell us, O Guide ! by what strange natural laws...Barry Cornwall...... 473

The angel of the flowers one day............... Krumanacher........ 105

The autumual glories all have passed away.........Irs. TC. C. Hinney.... 275

The color from the flower is gone.............. B. Shelley......... 40

The cowslip, that bending.................... Niss Landon....... 20

The curious, clioice, clove Jnly flower.......... Draylon........... 168

The forward violet thus did I chide............. Shakespeare......... 384

The fox-glove lenves with caution given .........Anonymous......... 169

The garlands fade that spring so lately wove......Charlolle Smith...... 451

The holly ! the holly ! ol, twine it with the bay...Eliza Cook........... 201

The image of Love that nightly flics............ Thos. Woore......... 121

The jasmine throwing wide her elegant swect.... Cowper ........... 120

The jasmine, with which the queen of flowers.... Churchill.......... $12: 3$

The king told Gyges of the purple flower.........Burry Cornwall...... 37

The lilac, varions in array-now white........... Anonymous........ 115

The lily minds me of a maiden brow............. Robl. Buchanan..... 80

The loft follower of the sun ................ Thomson .......... 147

The Lord of Life walked in the forest one morn ... Miss Darty.......... 18:3

The mist still kovers round the distant hills.......Anonymous......... 397

The morning brightness showereth down from

heaven ........................... Grace Greenwood......

The opening bud that lightly swung............IIrs. E. O. Smilh..... 468

The pale and delicate Narcissus flowers......... L. E. Landon....... 52 
The pansy and the violet here.............. Drayton.......... 42 The rose I sing sprung from no earthly mould .... Miss $F$. M. Cau/kins... 313 The rose $n$ 'er erag or vale....................Anonymous........ 100 The snowdrop! 'tis an English flower.......... Wordsworth......... 20 The snowdrop, wititer's timid ehild.............Mrs. Robinson....... 24 The snowdrop is the herald of the flowers....... Westwood ......... 19 The spring is eome, the violet's gone............Lord Byron......... 41 The stormy Nareh is eome at last.............. C. Bryant....... 410 The stream with languid murmur ereeps......... Coleridge.......... 75 The summer-time has eome agaiu.............R. II. Sloddard...... 458 The sun deelines, his parting ray................Ifrs. Ifunter ........ 65 The sunlight falls on hill and dale.............W. P. Palmer........ 287 The siln stepped down from his golden throue... O. W. Holmes....... 164 The Tulip ealled to the Eglantine.............Anonymous........ 462 The virgiu lilies in therr white.............. Corvley............ 161 The wallfower -the wallnower ...............Moir............. 84 The water-lilies that glide so pale............... E. Landon....... 161 The withered leaves, trembling, love .......... Ella Ingram........ 195 The young maid stole throngh the eottage door.... Anonymous......... 12 Their groves of sweet myrtle let foreign lands reekon.

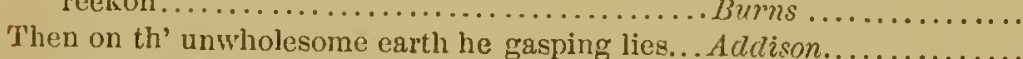
There are flowers soug about me Ther are ne............... Anonymous......... 417 There are that loves the shades of life.......... Langhorne......... 110 There grew a little flower onee.............. Hood .............. 71 There is a flower whose modest eye ............. Anonymors.......... 113 There is a little modest flower.................. Anonymous......... 89 There is a Reaper whose name is Death.........II. IV. Longfellow..... 481 There is a tongue in every leaf.................. Anonymous ........ 337 There is a willow grove aslaut the brook.......... Shakespeure......... 143 There, lovely bee-bird I mayst thou rove ... . . . Charlotte smith....... 127 There, said a stripling, pointing with mueh pride. Wordsworth........ 432 They were gathered for a bridal ............... Sarah L. P. Smith.... 38 i This little flower from afar.................... R. Lowell........ 11 Those evening elouds, that setting ray............... Sir IV. Scolt.......... 497 Those few pale autmonn flowers $1 . \ldots \ldots \ldots \ldots \ldots$. Caroline Southey..... 474 Thou art to all lost love the best ............... Hermack.......... 144 Thou bearest flowers within Thy hand.......... Dora Greenvell....... 16. 142 Thou blossom bright with antnmn dew..........W. C. Bryant........ 2ri Thou first-born of the year's delight............. Keble............ 21

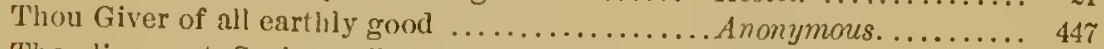
Thou lintrerest, Spring, still wintry is the seene... Sorthey............ 449 Thongh no more the musing ear ............ Southey............... 294 Thongh severed from its nalive clime.........Mrtin $\ldots \ldots \ldots \ldots \ldots$. Time was when thy golden ehain of llowers...... Anonymors........... 20. 'Tis Christmas eve, full plain... ............ C. T. Brooks........ 30. 30 i "lis holy time. The evening shade........... G\&O. D. Prentice...... 385

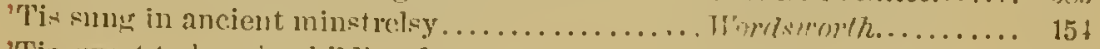
'Tis sweet to love iu childhood................ Eiizu cook......... 
'Tis the last rose of enmmer................. Thos. Mloore. . .... 103

To be a flower 1 which would you be............Anonymous......... 321

Tread aside from my starry bloom............Anonymous........ $3{ }^{2} 6$

'Twas midnight -through the lattiee wreathed....Thos. Moore........ 123

Under the mistletoe, pearly and green ...........Anonymous........ 198

Unfold thy faee, uminask thy ray .............. Charles Harvey....... 301

Unwatehed the garden bough shall sway........... Tennyson........ 502

Upon the sunny bank....................... Anonymous.......... 169

We are blushing roses.................... Leigh IIunt........ 475

We have left behind us....................Barry Cornecull....... 425

We eat down and wept by the waters............Lord Byron........ 141

We tend the flowers of every lue...............Mrs. Ifale .......... 368

We wreathed about our darling's head the morn-

ing-glory bright . .......................Afaria Lowell........ 359

Weak with niee sense, the elaste mimosa stands..Darwin............ 109

Weave thee a wreath of woodbine, ehild......... Anonymous......... 136

Wee, inodest, crinson-tipped flower ............Burns............ 14

Weleome, dear heart, and a most kind gool-

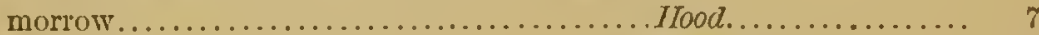

Weleome, mild harbinger of spring............ Barton.......... 30

Well, onee I was a little girl.................II. E. G. Arey...... 361

What first iuspired a bard of old to sing......... Keats............. 51

What is so rare as a day in June..............J. R. Lowell......... 334

What shall I eall thee...................... Caroline A. Briggs.... 370

When beehen buds begin to swell............W. C. Bryant....... 41

When first the friendship flower is planted.......Milnes............ 323

When I survey the bright................W. Hubington....... 436

When last we paeed these sylvan wilds, dear

friend .................................W. P. Palmer......... 283

When Nature tries her finest toueh........... Keble............ 340

When summer's sunny hues adoru............ Pinckney.......... 326

When syeamores are throwing...............W. Bowen.......... 488

When the copsewood is the gremest........... Sir Walter Scott..... 118

When the summer breeres have died away........tumes Dixon......... 277

When the winds blow......................Bary Cornivall...... 408

When with a serious musing I behold .........G. Withers........ 159

Wherefore little fluttering things............... IFilliam P. Palmer... 379

White bud 1 that in meek beanty so rost lcan.... Croly............. 73

Whom do we erown with the laurel leaf ?........Elizu Cook ........ 153

Who would have thought a thing so sliglit....... Itarlley Coleridge.... 499

Whose sad inhabitants cach year wonld eome.... Shelley............ 188

Why tremblest thon, aspen? no storm threatens

nigh ..................................... 184

Why do ye weep, sweet babes ? ean tears........ Robert IIerrick...... 66

Why this flower is now ealled so.............. Herrick............ 80 
Wild blossoms of the moorland, ye are very dear

With drooping bells of clearest blue............. Heber

Withering-withering-all are withering...

Ye field flowers! the gardens eclipse you 'tis true......................................

Campbell............. 187

Yet one smile more departing, distant sun.......W. C. Bmyant........ 270

You ask what thowers I love the best............. Caroline Liustis. 







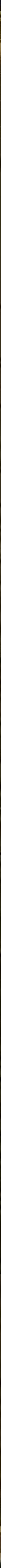


